CONTRADIÇÕES NA

\section{PRESERVAÇÃO DA}

ARQUITETURA MODERNA

SILVIO OKSMAN

ORIENTAÇÃO

PROFa DR ${ }^{a}$ BEATRIZ MUGAYAR KÜHL

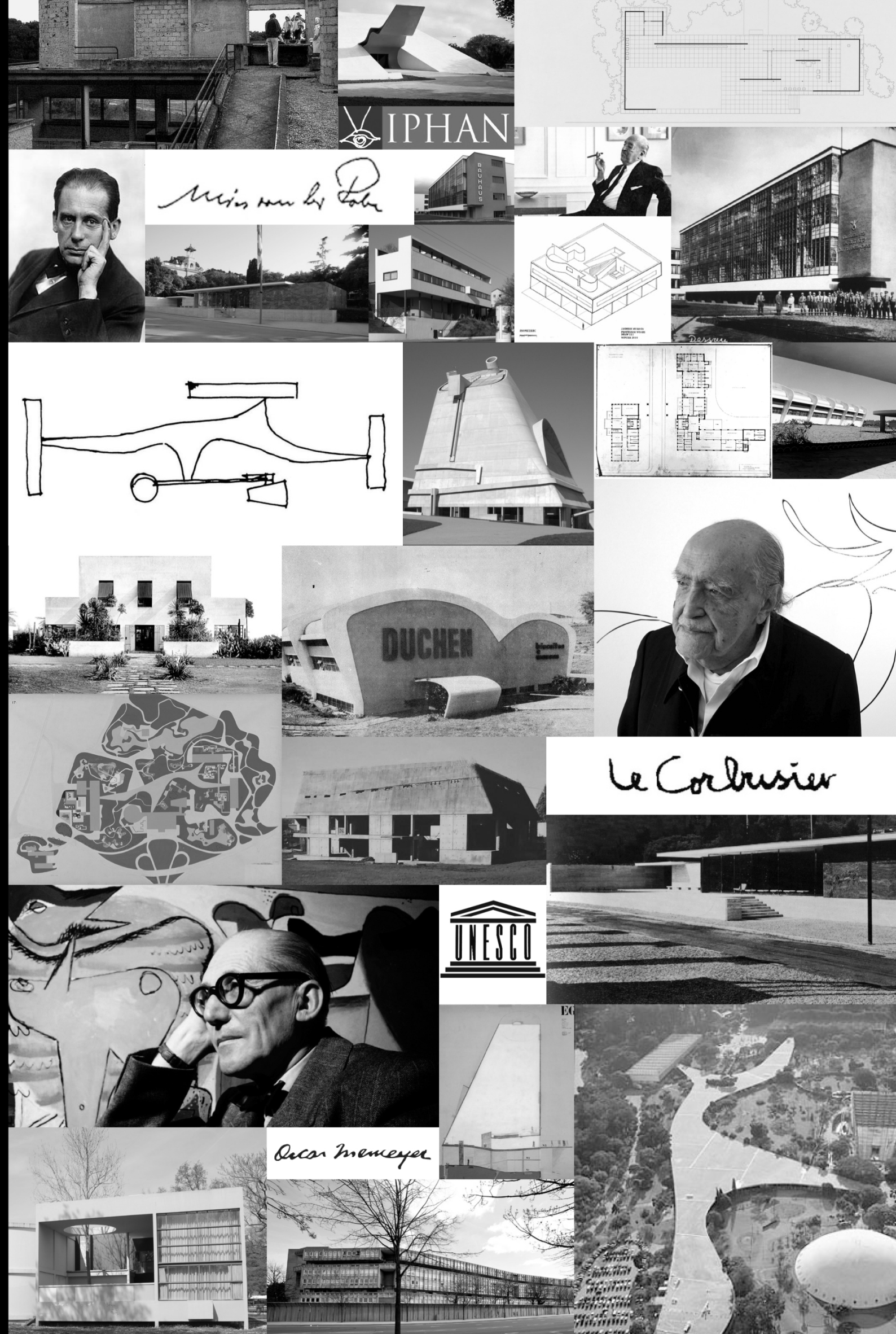


FACULDADE DE ARQUITETURA E URBANISMO UNIVERSIDADE DE SÃO PAULO

Área de concentração: história e fundamentos da arquitetura e do urbanismo

SILVIO OKSMAN

CONTRADIÇÕES NA PRESERVAÇÃO DA ARQUITETURA MODERNA

Tese apresentada à Faculdade de Arquitetura e Urbanismo da Universidade de São Paulo para obtenção do título de

Doutor em Arquitetura e Urbanismo

PROF ${ }^{a}$. DR ${ }^{a}$. BEATRIZ MUGAYAR KÜHL 
À profa Beatriz Kühl, mais que orientadora, pelo constante incentivo e apoio figura essencial no meu percurso até aqui. Às professoras Anna Beatriz Ayrosa Galvão e Fernanda Fernandes pelas contribuições na banca de qualificação essenciais para direcionar os trabalhos finais

Aos professores e amigos que contribuiram com diversas conversas, indicações de bibliografias e debates: Milton Braga, Paula Santoro, Monica Junqueira, Sabrina Fontenelle, Silvana Rubino, Ana Lanna, Paulo Garcez, Nadia Somekh, Simona Salvo, Renato Cymbalista, Silvia Wolff, Sonia Manski, Lara Melo Souza, Eduardo Gurian, Helena Ayoub, Antonio Carlos Barossi, Ana Paula Pontes, Catherine Otondo, Shundi Iwamizu, Andre Vainer, Ligia Miranda, Regina Meyer, Ana Maria Belluzzo, Eduardo Colonelli, Vito Macchione, Sarah Feldman, Ilan Szklo, Thais Marcussi, Danielle Dias, Vinicius Andrade, Renata Semin, Luca Rossato, Pietro Massai, Marcelo Balzani, Anderson Freitas, Regina Tirello, Heitor Frugoli, Pedro Puntoni, Jose Magnani, Victor Mori, Juliana Prata, Dalva Thomaz, Marta Bogea, Luis Antonio Jorge, Flavia Brito, Mariana Rolim, Deborah Neves, Felicia Knobloch, Juca Pires.

\section{Oksman, Silvio \\ 041c Contradições da preservação da arquitetura moderna / Silvio} Oksman. - São Paulo, 2017.

$227 \mathrm{p}$. il.

Tese (Doutorado - Área de concentração: História e Fundamentos da Arquitetua e do Urbanismo) - FAUUSP. Orientadora: Beatriz Mugayar Küh

Patrimônio cultural (Preservação; Restauração) 2. Arquitetura moderna I. Título

CDU 72.025 .3
Ao Jose Armênio Brito Cruz, pelo incentivo e pelas importantes oportunidades oferecidas

Aos Funcionários do CONPRESP, CONDEPHAAT e IPHAN que viabilizaram a pesquisa nos acervos

À Dina Uliana, Eliana Marques e Maria Jose Polletti pelas ajudas na pesquisas das bibliotecas da FAU

À todos os alunos da Escola da Cidade e de outros cursos oferecidos por exigir uma constante reflexão sobre os vários temas que tratamos

À toda a equipe do Keeping it Modern FAU

À Deborah Cardoso, Heloisa Prado e Jose Armando Macedo pela ajuda em manter o equilibrio

À todas as pessoas que colaboraram nos trabalhos do escritório, especialmente Rodrigo Garcia, Aline Figueiredo Mayra Rodrigues, Caroline Endo e Liz Arakaki

À Beatriz Vicino pela parceria dos últimos anos, pelas provocações constantes e ainda pela diagramação da tese

Aos amigos que estiveram sempre por perto neste últimos anos Paulo Mattos, Tati Machado, loram Finguerman, Maira Peixeiro, Carlos Livieres, Paula Fontana, Vanessa Ferrari, Carolina Bueno, Marcio Ballas, Paula Gama, Mirella Marino, Mariana Vaz, Luana Radesco

À todas as pessoas do CONDEPHAAT, UPPH, DPH e CONPRESP pela possibilidade de discussões múltiplas sobre as questões que envolvem a preservação do patrimonio

À Fany, Sui, Fernanda, Marcus e Mila e toda a família Villela

À Joana pela doçura e cumplicidade

À Dora pela alegria e intensidade

À Lele pela tranquilidade, pelo apoio e por compartilhar este e tantos outros projetos 
O presente trabalho trata do reconhecimento e da preservação da arquitetura moderna como patrimônio cultural. Trabalha especificamente com a discussão sobre a interferência dos arquitetos modernos nas suas próprias obras. Analisa de que forma a sua atuação e de seus herdeiros por vezes beneficia, por outras prejudica a preservação dessa arquitetura. Pretende discutir como a recente valorização da produção moderna como patrimônio cultural sofre de interferências pela pequena distância temporal entre a sua produção e o seu reconhecimento.

Essas interferências entram em conflito com as diretrizes contemporâneas de preservação que fundamentam este trabalho, principalmente a Carta de Veneza de 1964 que, por sua vez, foi estabelecida a partir dos princípios do restauro-crítico, que propõem um olhar mais abrangente para o patrimônio cultural, sem priorizar a abordagem do autor que tende a ser pouco sensível aos valores culturais atribuídos à própria obra.

A tese discute o contexto histórico em que a arquitetura moderna passa a ser abordada como patrimônio cultural: a segunda metade do século XX, com o questionamento dos paradigmas modernos, as novas posturas pós-modernas e as discussões sobre a preservação do patrimônio cultural.

Por fim, a obra do Parque Ibirapuera - projeto de Oscar Niemeyer dos anos 1950, construído para a comemoração do IV Centenário da cidade de São Paulo - é discutida a partir de todos os processos dos orgãos de preservaçăo (IPHAN, CONDEPHAAT e CONPRESP). É possivel, a partir desses casos, verfícar como o arquiteto, ao longo de toda a existência do parque, interferiu nas decisões de intervenção - mesmo após a sua 
This study examines the recognition and preservation of modern architecture as cultural heritage. More specifically, it presents a discussion on modern architects' interference in their own work. It considers how their work and that of their heirs facilitate or hinder preservation of modern architecture, and how recent heritage listings of modern architecture are affected due to the short time interval between their production and recognition

This interference contradicts the contemporary preservation guidelines underpinning this work, in particular the 1964 Venice Charter, which was based on critical restoration principles. These guidelines pose a more comprehensive view of cultural heritage without prioritizing an authorial approach that would ten to be little sensitive to the cultural values instilled in the work itsel

The thesis discusses the historical context in which modern architecture came to be viewed as cultural heritage: the second half of the 20th century and its revisions of modern paradigms, new postmodern stances, and discussions on cultural heritage preservation. Finally, this study discusses Parque Ibirapuera - the park complex that Oscar Niemeyer designed in 1950 to commemorate the city of São Paulo's 4th centennial - in view of the listing procedures adopted by heritage agencies (IPHAN, CONDEPHAAT and CONPRESP). From these cases, one can draw evidence of how Niemeyer intervened in decisions concerning the park from its inception and continued to do so, even posthumously. 


$\begin{array}{lll}27 & \text { VALORIZAÇÃO DO PATRIMÔNIO } \\ 28 & \text { Valor econômico do patrimônio } \\ 34 & \text { Pós-moderno } \\ 35 & \text { Patrimônio e cidade } \\ 47 & \text { Moderno como patrimônio }\end{array}$

51 PRESERVAÇÂO DA ARQUITETURA MODERNA - AUTORIA

$\begin{array}{cc}56 & \text { Reconhecimento de valor } \\ 61 & \text { Vila Savoye - Le Corbusier }\end{array}$

63 Tombamento das obras de Oscar Niemeyer

68 Arquitetura e outras artes

70 Ausência de reconhecimento

75 Robin Hood Garden - Alison e Peter Smithson

81 Fabrica Peixe-Duchen - Oscar Niemeyer

91 Sociedade Harmonia de Tênis - Fabio Penteado

92 Intervenções no moderno

95 Edifício Pirelli - Gio Ponti

96 Mitificação

99 Weissenhofsiedlung - varios autores

103 Casa Modernista da Rua Santa Cruz - Gregori Warchavchik

106 Construção a partir do projeto

113 Teatro Cultura Artística - Rino Levi

115 Igreja de São Pedro de Firminy - Le Corbusier

121 Pavilhão de Barcelona - Mies van der Rohe 
125 CONTRADIÇÕES NA PRESERVAÇÃO DA ARQUITETURA MODERNA PARQUE IBIRAPUERA

125 Breve histórico

145 Tombamento

147 Intervenções no parque

149 Ampliação do Pavilhão das Indústrias - edifício da Bienal

150 Plano diretor

160 MAM

165 Pavilhão Lucas Nogueira Garcez - Oca

171 O novo auditório

181 Marquise

188 Post mortem

195 CONSIDERAÇÕES FINAIS

205 CRÉDITOS DAS IMAGENS

217 REFERÊNCIAS BILIOGRÁFICAS 
Abordar obras modernas como patrimônio cultural vem se mostrando um campo de discussões bastante problemático. A dificuldade de aproximar-se da produção recente leva a posturas questionáveis do ponto de vista das diretrizes contemporâneas de preservação do patrimônio cultural.

Esse assunto foi abordado na minha dissertação de mestrado Preservação da arquitetura moderna: a FAU de Vilanova Artigas (2011) e um dos temas que já estava presente nesse trabalho, a questão da autoria, pareceu merecer um aprofundamento num estudo posterior.

Como o reconhecimento do moderno é um processo recente e, portanto, as intervençôes também o são, a discussão ainda e acalorada e demanda aprofundamento, principalmente devido ao olhar fetichista lançado para o moderno. Como abordar a produção do século XX como patrimônio cultural sem se contagiar pela militância mobilizada, de forma geral, pelo moderno? Nesse sentido, não apenas a produção de arquitetura, mas o posicionamento político e a produção teórica construíram uma "aura" em torno dessa produção, dificultando uma abordagem crítica.

O período do doutorado coincidiu com minha participação no Conselho de Defesa do Patrimônio Histórico, Arqueológico, Artístico e Turístico do Estado de São Paulo fesa do Patrimônio Histórico, Arqueológico, Artístico e Turístico do Estado de São Paulo
(CONDEPHAAT) como representante do Instituto de Arquitetos do Brasil, Departamento (CONDEPHAAT) Como representante do Instituto de Arquitetos do Brasil, Departamento abordagem do patrimônio cultural. O trabalho no Conselho consistiu na elaboração de

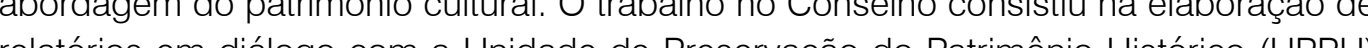

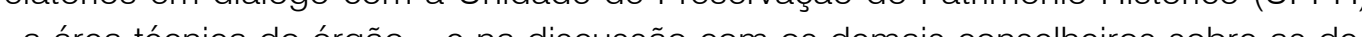

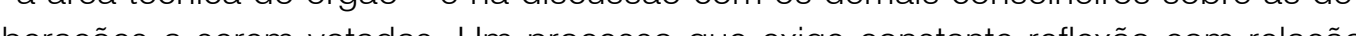
lberaçöes a serem votadas. Um processo que exige constante reflexáo com relação aos temas envolvidos, na perspecliva do agente publico, e que intertere diretamente no patrimônio cullural, nas cidades e na sociedade. Trata-se de tombamentos e definiçoes de diretizes para preservaçáa, aprovaçăo de projetos mens tombados e areas envoltorias, discussão e revisão de procedimentos e até multas e puniçoes para açōes que descumpram as regras estabelecidas. O Conselho e formado por representantes da sociedade que podem disculir o tema com propiedade. A mulliplicidade de olha-

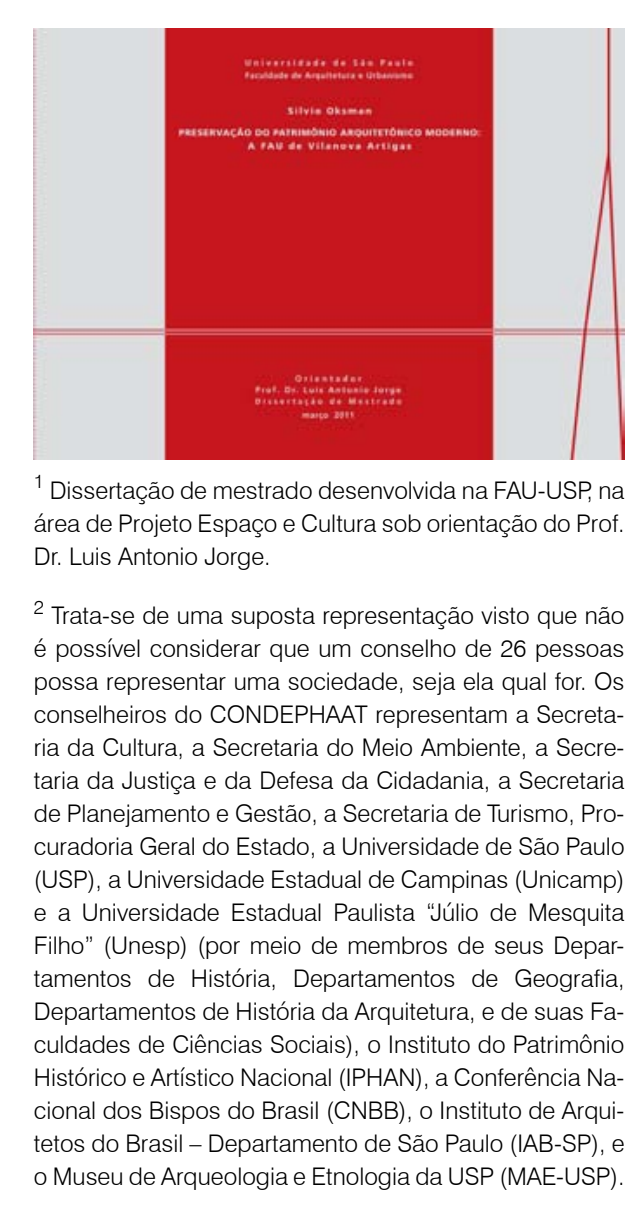

INTRODUÇÃO 


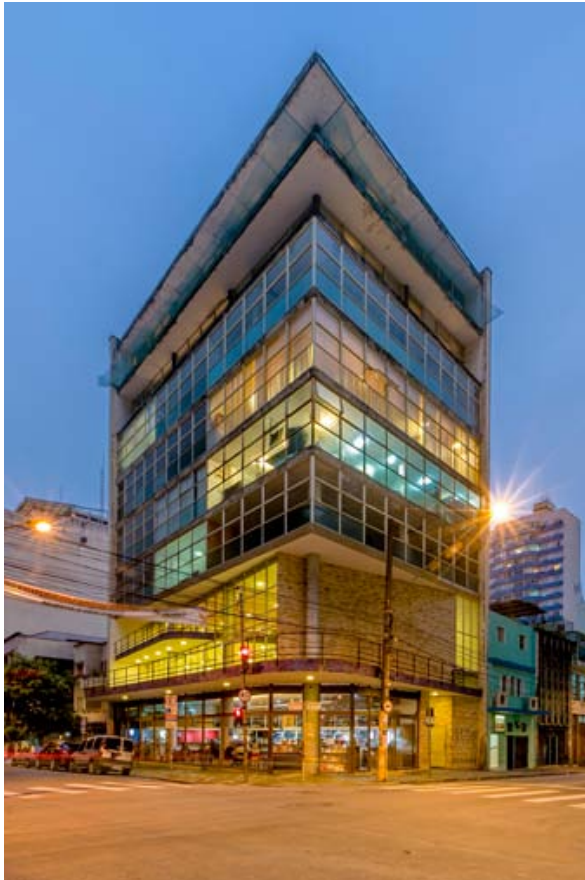

01. Edificio Sede do Instituto de Arautiteos do Bras
Departamento de Säo Paulo.

cientistas sociais e arqueólogos permite discussōes que se aproximam daquilo que se convenciona dizer "atividade multidisciplinar"s, tão almejada no campo da preservação do patrimônio.

A possibilidade de desenvolver diversos projetos e consultorias para intervenção em bens culturais também colocou as discussões do campo acadêmico em diálogo com as propostas de projeto, e vice-versa. A reflexão sobre a preservação, sob otica do restauro-critico, que e a base para o desenvolvimento deste trabalho, estabe lece a necessidade de aprofundamento caso a caso, e isso se confirma na elaboração dos projetos. Somente a partir do conhecimento dos bens trabalhados e que se pode propor intervençoes que respeltem os valores reconhecidos para cada siluaçâa apresentada, náo sendo possivelestabeleceruma metodologia rigica que resulte en regras que deem conta da multiplicidade de questões levantadas a cada situação. Trabalha-se desse modo, com princípios e diretrizes, e não com regras.

Ter trabalhado com a equipe do meu escritório o projeto de restauro da sede do Instituto de Arquitetos do Brasil - edifício inaugurado em 1953, em São Paulo, cujo projeto foi vencedor de um concurso e coordenado por Rino Levi, um dos mais reconhecidos arquitetos brasileiros - foi um trabalho essencial para o desenvolvimento desta tese, já que as questões abordadas durante o projeto foram rigorosamente as mesma que surgiram na pesquisa acadêmica: a elaboração de um projeto de restauro em um edifício moderno. A possibilidade de consulta ao projeto executivo completo e ao grande acervo iconográfico, o acesso às informações de pessoas que trabalharam com os arquitetos-autores $\mathrm{e}$, mais relevante ainda nesse caso, a quantidade enorme de arquitetos que vivenciaram esse edifício ao longo de toda a sua existência ${ }^{4}$ exigiram cuidado extremo para não sucumbir às ciladas que o tema coloca e que serão discutidas neste trabalho. Além dessas questões, debrucar-se sobre um projeto de restauro evidencia dificuldade da tomada de decisão, da dúvida de preservar da melhor forma possível da

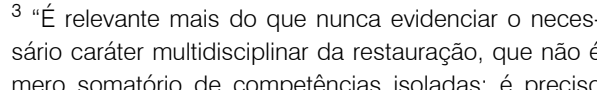

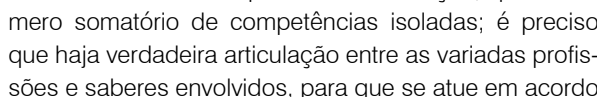

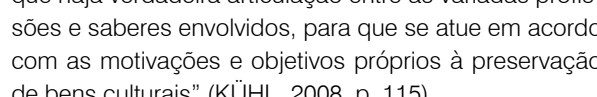

40 edificio, além de sede do Instituto de Arauitetos do

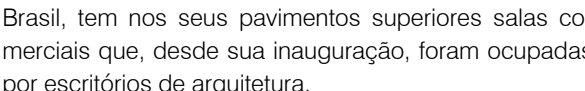
5 Em 2015, tui professor da oficina Contemporary
Design in Historic Centres - A Necessity for the Present

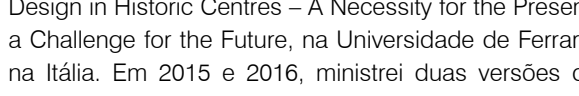

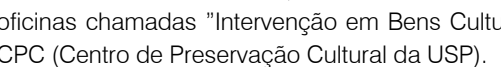

projeto e compreender as dificuldades da passagem do ensino das teorias e diretrizes para a aplicação prática, e ainda perceber que, no caso de projetos de restauro, não hà Imite entre teoria e pratica mas sim uma constante troca em um processo de retroalimentação. Os trabalhos na área de preservação do patrimônio cultural se posicionam na intersecção dos campos - que ainda demandam outros olhares específicos, para além da arquitetura e da história.

A experiência como professor no Estúdio Vertical, da Escola da Cidade ${ }^{6}$, trouxe um importante aporte principalmente no que diz respeito às discussões de escala urbana. Ja no Programa de Aperfeiçoamento de Ensino (PAE), com a disciplina Subsidios Investigativos e Projetuais para a Preservaçáo do Patrimônio Edricado", ministrada nos primeiros semestres do 2014 e de 2015, pude observar as questoes do ensino e da pesquisa no campo da preservação.

Nesses processos ficou evidente que o campo da preservação, que está comumente vinculado à área de história nas estruturas mais comuns das faculdades, não tem estabelecido o necessário diálogo com outras áreas, privando o ensino do olhar múltiplo essencial para a compreensão do tema. Não é possível realizar projetos em bens culturais sem o conhecimento do campo teórico e de diretrizes contemporâneas de preservacão, bem como é impossivel operar essas diretrizes sem uma abordagem e discussão de projeto.

A reflexão colocada neste trabalho é, portanto, sobre a articulação de todas essas atividades com um esforço de realizar um dialogo dentro do campo entre disações que não levem ao engano, ao falso?

Dando continuidade ao exposto nesta introdução, alguns assuntos abordados neste traba/ho demandam um esclarecimento prévio a fim de evitar equívocos na compreensão da hipótese levantada.

O primeiro diz respeito ao recorte temporal. O termo "moderno", adotado ao mas da produção do início do século XX até meados dos anos 1980, quando já não é longo do texto, pode levar a um questionamento sobre qual arquitetura se está efetivamente tratando. Evidentemente, não e apenas do modemismo que se está falando, mais possivel falar em produção de uma arquitetura moderna, mas de um olhar crítico $e$ de preservaçăo dessa produção. Um recorte temporal preciso, com inicio e fim, nesse caso, é dificil de ser determinado e não se faz necessário. Isso pode ser percebido pela variedade de períodos estabelecidos pelos diversos autores que estudam o moderno.

As primeiras obras que abordam essa produção têm início e fim em períodos diferentes. Nikolaus Pevsner em Os pioneiros do desenho moderno (1936) faz um recorte que se inicia em William Morris, ou seja, na metade do século XIX, e termina em Walter Gropius, nas primeiras décadas do século XX. Reyner Banham, já na segunda metade

Desde 2009, faco parte do corpo docente da Escolac
didade, no curso Estúdio Vertical que e uma discipina (a) liscussoese etrabalhos com tentes
les sobre arquitetura e cidade.

A FAU-USP divide-se em três departamentos AUH

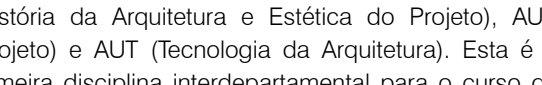
Arquitetura e U Urbanismo da FAU (o curso de Design

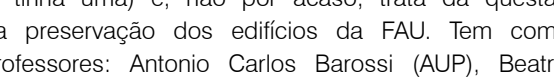

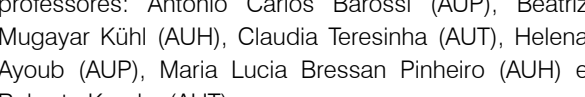

A participação em congressos e os cursos que ministrei ${ }^{5}$ dentro e fora do país foram fontes fundamentais para reflexão, pois permitiram integrar as abordagens de 


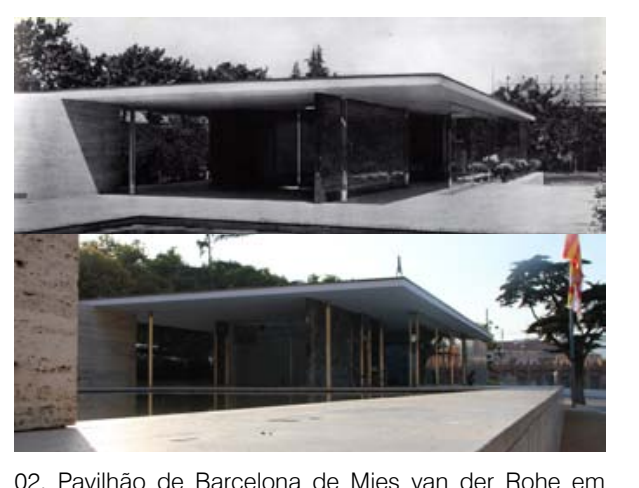

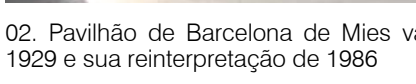

do século XX, em Teoria e projeto na primeira Era da Máquina (1960) traça um período que vai do inicio do século XX (1900) até o final da década de 1920. Leonardo Benévolo em História da arquitetura moderna (1971) inicia sua periodização na Revolução Industrial no século XVIII, e faz um longo percurso que vai até o início dos anos 1970.

Simona Salvo aborda a produção do século XX, sob o viés de sua preservação, sem entrar nas discussões da periodização da arquitetura moderna e de suas diferentes correntes, assim, trabaha como perfodo do "novecento" - seculo XX- na sua obra mas recente Restaurare il Novecento Storia, esperienze e prospettive in architettura (2016)

Carbonara também levanta a questão do recorte temporal:

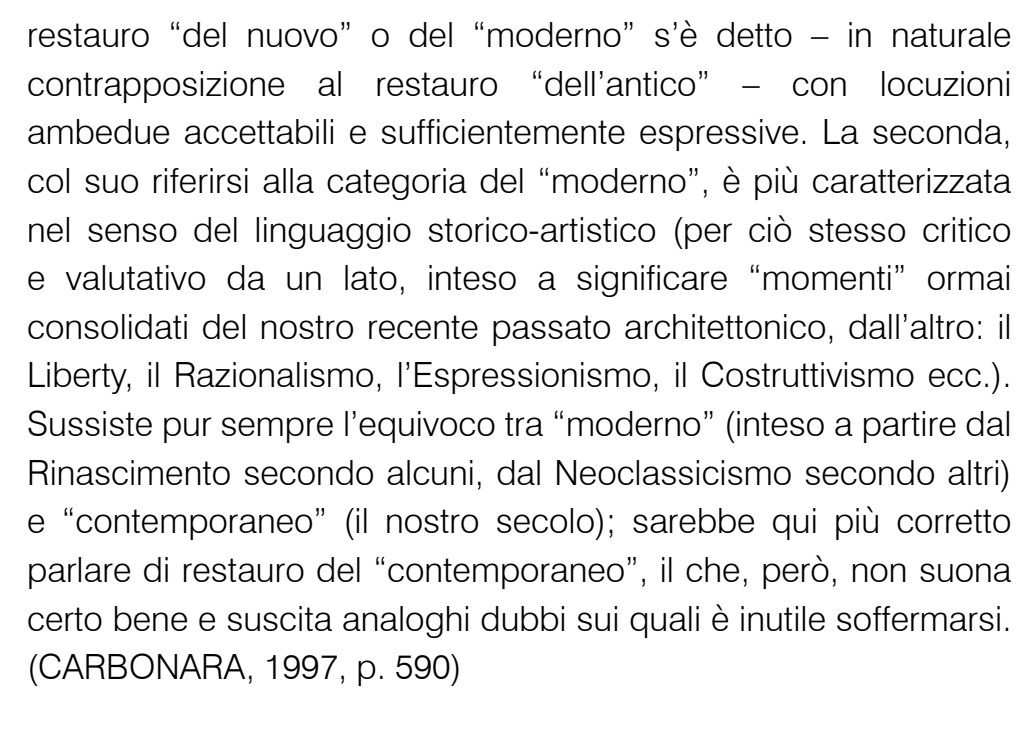

Portanto, a discussão colocada não se altera em função de um recorte temporal especifico. Sáo obras que estabelecem um conjunto impreciso, já que programas, sistemas construtivos e estilos são bastante diversificados, e que estão reunidas neste trabalho pelo fato de pertencerem a um conjunto de obras e autores consagrados pela historiografia da arquitetura moderna, o que dificulta um olhar crítico distanciado para a sua preservação.

Além disso, apesar das diferenças entre as legislações sobre preservação de patrimônio existentes em cada país, este trabalho aborda a questão principalmente com base em uma bibliografia que trata da discussão contemporânea de preservação, por isso, náo entra na discussáo dos critérios locais de temporalidade, mas aborda o problema das obras em si. Portanto, independentemente dos períodos para o reconheci-

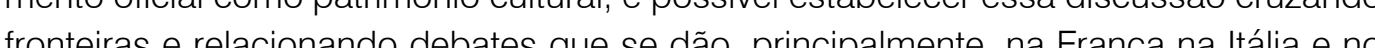
Brasil.
Deve-se determinar, também, uma distinção entre o campo da preservação e o da história. A relação entre as duas áreas tem acarretado leituras que misturam indistintamente os temas. A preservação se apropria dos trabalhos da história como um instrumento essencial para a atribuição de valor e preservação. O campo do patrimônio cultural trabalha com ações que, ao olhar para o passado, propõem uma ação no presente, contemporânea que visa uma transmissão ao futuro O olhar para essa produção a partir do campo da preservação de patrimônio cultural não pretende reestabelecer os a partir do campo da preservação de patrimononio cultural não pretende reestabelecer os oferecer contribuições significativas para esclarecimentos historiográficos.

Esta tese trabalha amparada pelas diretrizes estabelecidas pelo restauro-crítico que abordam o tema do restauro como ação contemporânea. Isso significa dizer que não é possível considerar qualquer intenção de resgate de um estado supostamente original. Ações de repristinação, comumente utilizadas em preservações em geral e do moderno com maior frequência, não são aceitas, por essa linha, como preservação de patrimônio. Pelo contrário, essas ações levam ao equívoco da compreensão da produção moderna, com "falsos" à imagem e semelhança dos originais. São intervenções que não evidenciam o envelhecimento e a passagem do tempo, com a sobreposiçaão de marcas que contam a história da obra ao longo de sua existência, e partem da seleção de algumas camadas históricas em detrimento de outras ${ }^{8}$

O restauro-crítico, base para a Carta de Veneza de $1964^{\circ}$ e já bastante discutido e trabalhado por diversos autores, tem como princípio a necessidade de conhecimento aprofundado dos bens. É a partir desse reconhecimento de valor que se pode trabalhar aprofunctarion cutural. Significa dizer que para cada caso estudado, vale trabalhar ficos e, jamais genéricos, serão identificados para que sejam preservados. Portanto, a hipótese de regras gerais preestabelecidas fica descartada Por se tratar de uma metodologia aberta sem definicão de um sistema rígido, exige-se uma abordagem criterioEntretanto, são estabelecidas também diretrizes imprescindíveis para a preservação . "conservadora".

Uma dessas críticas diz respeito ao falso, que é a questão fundamental para o desenvolvimento desta tese. Segundo Brandi "[...] a restauração deve visar ao restabelecimento da unilade potencial da obra de arte, desde que isso seja possivel sem cometer um falso artistico ou um falso historrico, e sem cancelar nenhum traço da passagem da obra de arte no tempo" (2004, p. 33). Isso significa que é necessário cuidar para que as obras transmitam, dentre os valores reconhecidos, a possibilidade de compreensão dos momentos pelos quais passaram. Momentos não no sentido de eventos, mas como passagem do tempo que deixa marcas e que são essenciais para a apreensão daquilo que se almeja preservar.

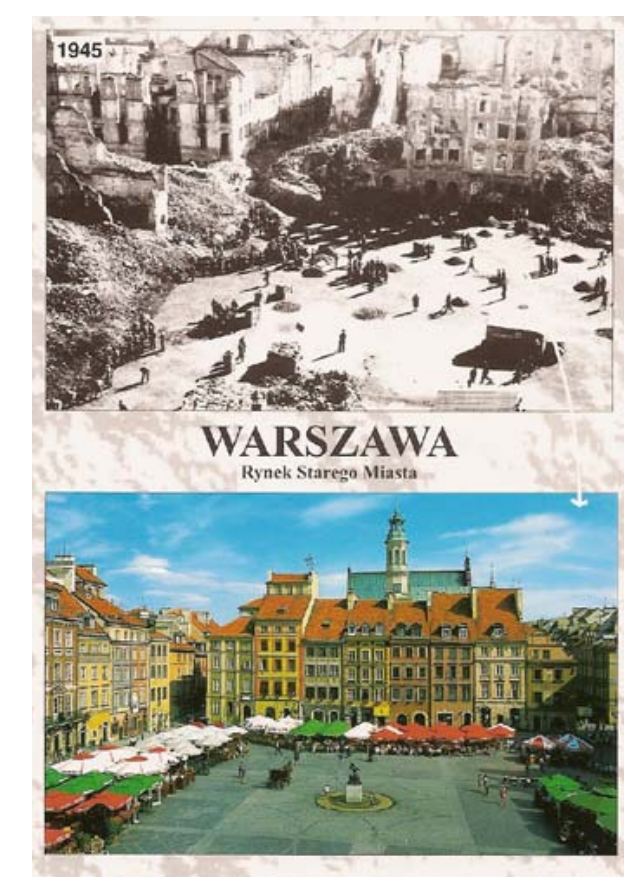

Um exemplo muito importante disso foi a construçäa Guerra Mundial. Uma area da da cidade foi duramentition A sociedade se organizou e decidiu " "ecoonstruit" a

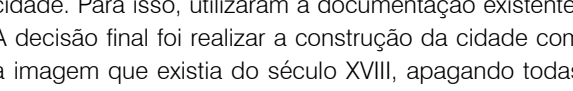
as intevennçöes realizadas no século XXX e as marcá

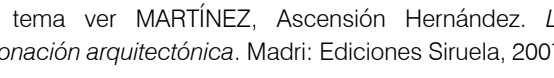
(Cartäo-postal mostrando o centro histótico de Varsóvia
logo apos all Guerra Mundiale e depois da intervengạa
dos anos 1960) Documentit final do II Congresso Ititracioional de alizado em 1964, a Carata de venezza e suas dirictrizes

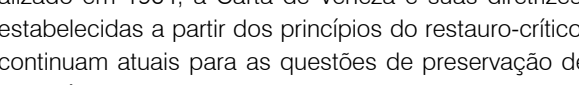
continuam atuais p
patrinonio cultural. 


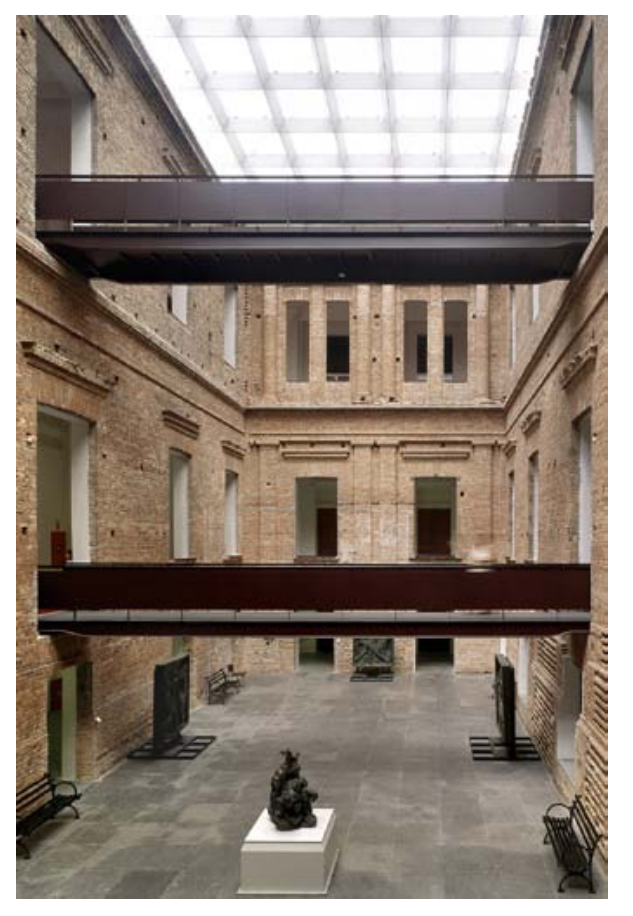

03. Pinacoteca do Estado de Săo Paulo apresentado chamava-se Preservação e reconstrução: contradiçōes na salvaguarda da arquitetura moderna - 0 termo se refere a ações que se mostram inaceitáveis do ponto de vista da preservação. Não significa dizer que as construções à imagem e semeIhança sejam aberrações e não tenham o seu lugar, mas elas precisam ser claramente explicitadas. Não se aceita, a priori, a ideia de que um edifício possa ser construído com'era, dov'era ${ }^{10}$ para substituir outro que por diversos motivos tenha desaparecido". Por mais que haja empenho em se realizar uma construção fiel a um original, diversas condicionantes de ordem material, de contexto, de execução, de avanço de tecnologia impedem uma reprodução idêntica, exatamente como era em todos os seus aspectos formais e técnico-construtivos. Nesse sentido, serão utilizados termos como "reinterpretação" ou "releitura", que têm sua importância pela possibilidade de uma percepção espacial e material de obras relevantes. Desde que bem sinalizada essa intenção, essas reinterpretaçoes e releituras têm caráter did́tíco insubstitúvel.

Ascensión Martínez trabalha com essa questão, não apenas no moderno, em sua obra La clonacion arquitectónica (2007). O próprio titulo indica a impossibilidade de se adotar o termo "reconstrução" para o caso da preservação, pois se trata, na verdade, de "clones". Essa obra, entbora pouco cilada nesta tese, foi fundamental para o desenvolvimento da dissertação de mestrado e apontou para questões desenvolvidas aqui.

O olhar crítico para o moderno sob a perspectiva da preservação cultural evidencia a dificuldade de abordar temas que tangem a mitificação e a idolatria e são sempre polêmicos. Ao levantar eventuais problemas ou posturas questionáveis dos grandes mestres e discuti-los, pode-se entender que se trata de um trabalho que se posiciona contrário ao moderno e a seus autores Pelo contrário esta tese parte de uma grande admiração por toda essa produção, e que pode ter seu legado prejudicado exatamente pela dificuldade de se lidar com esse assunto. Ao debatê-lo, a tese pretende levantar questões que podem levar a uma perda signticativa de valores a de são dessa produção arquitetônica.

Intervençōes em edifícios anteriores ao século XX, com mudança de uso e alteraçōes significativas nos bens, são aclamadas pela sociedade e pela crítica pela poss bilidade de fruiçáo do edifício histórico, pela atribuição de novos programas e pelo diálogo entre o edificio existente e a arquitetura contemporânea. São inúmeros casos como o do Museu do Louvre e do Museu d Orsay, em Paris, da Pinacoteca do Estado, en São Paulo, do Museu Reina Sofia, em Madri, da Tate Modern em Londres. São poucas raras as manifestaçoes que se posicionam a favor do retorno ao estado original desses edifícios. Quando se trata do moderno, porem, a proximidade temporal e a admiração por determinados autores leva a uma postura multo menos propositiva, que sugere, na grande maioria das vezes, a recuperação desse suposto "estado original".

Nesse sentido, opera-se com alguns argumentos que serão o objeto central de discussão desta tese: a existência de projetos executivos completos que seriam a representação fiel do edifício original e a possibilidade de consulta aos arquitetos-autores ou a membros de suas equipes e familiares - que aqui serão chamados de herdeiros culturais e biológicos ${ }^{12}$, respectivamente.

O que se observa é que a partir dessas abordagens a preservação fica submetida a critérios frágeis, tanto pela convicção que se tem neste trabalho (cujas razões serăo desenvolvidas no decorrer dos capitulos) de que os projetos e inagens não são unformaçoes definithas sobre os edilcios, como por discursos riágeis, carregados de uma carga emocional que interfere em uma leitura isenta.

A hipótese colocada para o desenvolvimento deste trabalho é a de que a preservação da arquitetura moderna não demanda diretrizes específicas, mas sofre interferências que podem prejudicar substancialmente esse processo. Para além do momento histórico em que se dá o seu reconhecimento como patrimônio cultural o curto espaço de tempo que separa a construção da valorização tem resultado em abordagens que divergem das diretrizes contemporâneas de preservação de patrimônio cultural. Dentre essas interferências chama atenção a atuação dos autores e de seus herdeiros culturais e biológicos. A abordagem dessas pessoas é carregada de questões que mutas vezes passam ao largo da leitura de uma obra específica, mas que tem tido grande interferência nos processos de presenvação. Dessa forma, a tese pretende evidenciar como esse tipo de atuação pode pôr a perder ou distorcer um legado essencial para a compreensão da produção arquitetênica do século XX.

Para tratar desses temas, a estrutura do trabalho baseia-se em três capítulos que pretendem abordar a questáo do reconhecimento do moderno como patrimonnio, a interferência dos autores e seus herdeiros biológicos e culturais no processo de preservação e, por fim, utilizar o caso do Parque do Ibirapuera, de autoria de Oscar Niemeyer (1907-2012), para ilustrar as questôes discutidas nos capítulos anteriores.

O primeiro capítulo trata das discussões colocadas ao longo da segunda metade do século XX, após a Segunda Guerra Mundial. Esse recorte temporal tem uma lógica que compreende o momento em que os princípios da arquitetura moderna passam a ser questionados e se inicia o processo de reconhecimento do moderno como patrimônio cultural. Não se trata de esgotar a questão do reconhecimento e val orização do moderno, mas de compreender de que forma o momento histórico en qu processo se inicia interfere no seu desenvolvimento.

Os Congressos de Arquitetura Moderna (CIAMs) tiveram onze versões desde o primeiro, na Suíça, em 1928, até a última edição na Holanda, em 1959. Após uma interrupção entre 1937 e 1947, os princípios que haviam norteado os congressos até aquele ponto começam a ser revistos. E o momento no qual a segunda geração de arquitetos
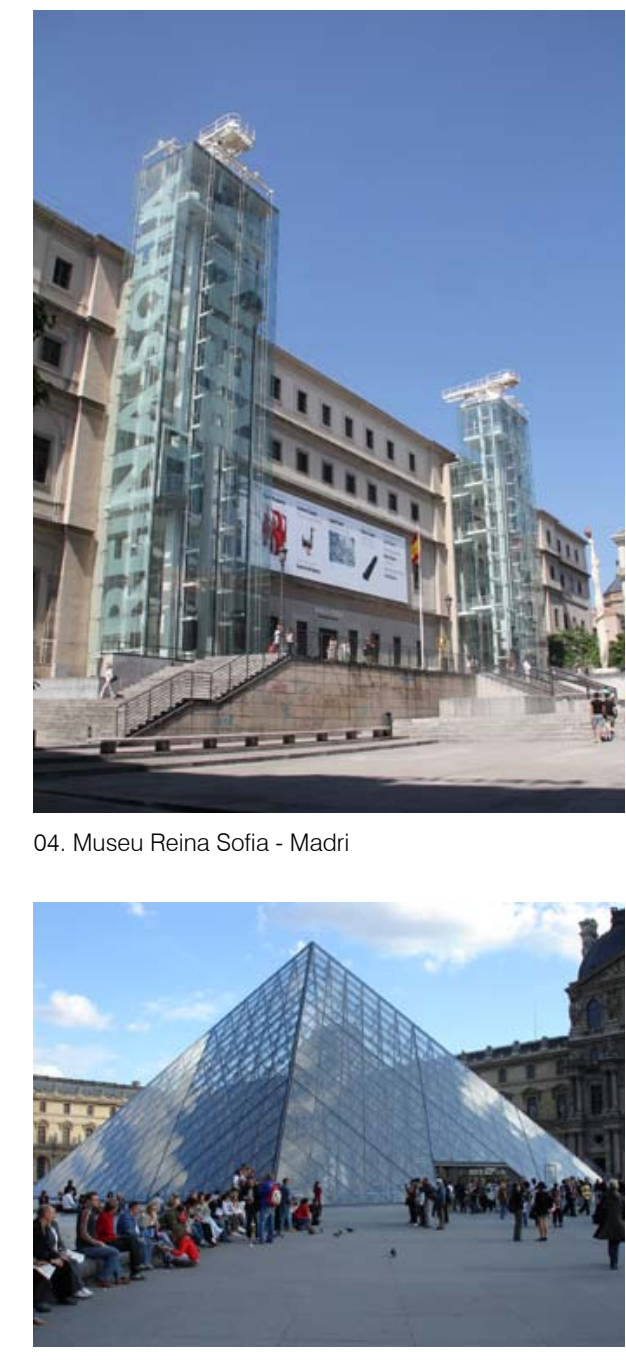

05. Museu do Louvre - Paris

12 Herdeiro cultural entendido como pessoas que têm
proximidade com obras e seus autores por terem tra- 
modernos toma a frente das discussões e passa a questionar os princípios da cidade funcional. Colocam na pauta temas até então evitados pelo comitê organizador.

O olhar para a cidade, a partir disso, passa a ser mais compreensivo com as preexistências, em certa sintonia com o olhar da preservação de patrimônio, que desde o início do século, a partir das proposiçōes de Giovanonni, já abordava a questão da qualidade dos centros das cidades. A idela de tabula rasa, da cidade ex novo, já não mais defendida. Essa mudança de olhar acontece, principalmente, em função das gran des destruçees das cidades duan por um processo de construção, em alguns casos de áreas urbanas inteiras.

É nesse momento, também, que ocorre uma ampliação do acesso à cultura, a chamada cultura de massa, que engloba um incremento substancial no turismo - e na economia. Esse processo tem forte interferência no campo da preservação do patrimônio cultural, que por vezes prioriza o potencial turístico e econômico em detrimento de ações mais criteriosas e de acordo com as diretrizes contemporâneas de preservação de patrimônio cultural.

A criação do DOCOMOMO, nos anos de 1980, inicia um processo de documen ação do moderno que, se não trata de uma questão objetiva de preservação dos ediftcios, estabelece um olhar sobre a necessidade do inventário dessa extensa produção.

Por fim, a estética proposta pelos pós-modernos que, a fim de negar a assertividade modernista, propõe uma liberdade absoluta de resgates estilisticos, com uma sado que, nesse sentido, poderia ser apropriado em novas construçōes.

É nesse contexto que o moderno passa a ser abordado como patrimônio cultural. Assim, sua valorização é contagiada também por essas questões do mercado cul tural. Soma-se a isso a dificuldade de abordá-lo como patrimônio, principalmente pela pequena distáncla temporal entre sua produça e sua preservaçao, levando a tem que serão aprofundados no segundo capítulo.

O segundo capítulo traz uma discussão central para a tese: a relação da preservação do moderno com seus autores. Pretende-se discutir como, a partir da proximidade temporal do reconhecimento do moderno com sua efetiva produção, os processos são contaminados por posturas que, muitas vezes, são de ordem pessoal. Há uma confusão entre obras e biografias que interfere nesse processo com questões que, mesmo podendo fazer parte da discussão, por vezes ganham maior espaço do que deveriam.

Assim, a discussão é feita com base na percepção de algumas posturas recorrentemente adotadas, tais como:
- A falta de reconhecimento pela proximidade temporal, que por vezes gerou a perda completa de importantes obras ou intervençōes de ordem pragmática que corromperam edifícios de forma irrecuperável

- O excesso de reconhecimento em função de um olhar mitificado que leva a ações de repristinação ou a novas construções idênticas às originais, com a utilização da documentação existente, ou, ainda, à imobilização e à ancapacidade, de ânea nos bens culturais;

- A construção ou complemento de obras a partir dos projetos executivos e imagens, em um processo de falseamento do que efetivamente foi o moderno

terceiro capítulo aborda o Parque Ibirapuera desde sua inauguração até os dias atuais, nos vários processos de intervenção propostos. A partir da pesquisa realizada nos processos dos orgāos de preservaçáo de património cultural - IPHAN (Instituto de Partimonio Historico e Artislico Nacional), CONDEPHAAT e CONPRESP (Conselho Municipal de Preservação do Patrimonnio Histórico, Cultural e Ambiental da Cidade de São Paulo) -, pode-se estudar como Niemeyer foi consullado e teve participação em todos os processos do parque, inclusive após a sua morte.

O próprio arquiteto se posiciona como arquiteto-autor, que seria a única pessoa com legitimidade para intervir no parque. Já os órgãos de preservação apresentam contradições claras ao deliberar sobre os projetos com posturas que tendem a preservar o "projeto original", que jamais foi construído na íntegra, com autorizaçōes e negações que se contradizem e com a figura do grande arquiteto pairando em todos os casos.

Por fim, é essencial pontuar que ao longo de todo esse processo de leituras, discussões e trabalho árduo, o diálogo constante com diversas pessoas foi fundamenlal para o desenvolum a agradecimentos gerais contribuíram de forma direta com a elaboração da tese.

No CONDEPHAAT, além das discussões já colocadas anteriormente, conversas com a presidente Ana Lucia Duarte Lanna e com os conselheiros Silvana Rubino, Paulo Cesar Garcez Marins, Heitor Frugoli, Sarah Feldman e Sueli Angelo Furlan trouxeram, cada uma delas, contribuições com olhares diferenciados para a questão da preservação, assim como minha relação com a equipe da UPPH, especialmente com Antonio Zagato, Deborah Neves, Lara Melo Souza, Silvia Wolff e Sonia Manski.

No CPC (Centro de Preservação Cultural da USP), Monica Junqueira de Camargo e Sabrina Fontenele foram incentivadoras e interlocutoras importantes na questão da preservação da arquitetura moderna. 
A possibilidade de diversas conversas com a professora Simona Salvo, da Università degli Studi di Roma "La Sapienza", que tem estudado a preservação do específica, a confirmação de algumas hipóteses levantadas pela tese.

A professora Fernanda Fernandes que, além da presença na banca de qualificação, acompanhou o trabalho com contribuições importantes principalmente no que diz respeito às questões da historiografia da arquitetura moderna.

Desde a banca de defesa da dissertação de mestrado, minha orientadora, Profa. $\mathrm{Dr}^{\mathrm{a}}$. Beatriz Mugayar Kühl, foi figura de presença central para o desenvolvimento desta tese. As discussões em campos diversos permitiram o aprofundamento de questões que nem sempre eram consenso, mas discutidas intensamente. Foram muitas as possibilidades de interação desde o estágio PAE na disciplina interdepartamental, o desenvolvimento do Plano de Conservação do edifício da FAU ${ }^{13}$, a discussão de vários processos do CONDEPHAAT ${ }^{14}$ além de inúmeras conversas que permitiram uma abordagem segura no campo do patrimônio cultural, muito mais abrangente do que o tema desta tese. A construção deste trabalho está completamente amparada nesse diálogo efetivo e, também, completamente referenciada em sua produção intelectual.

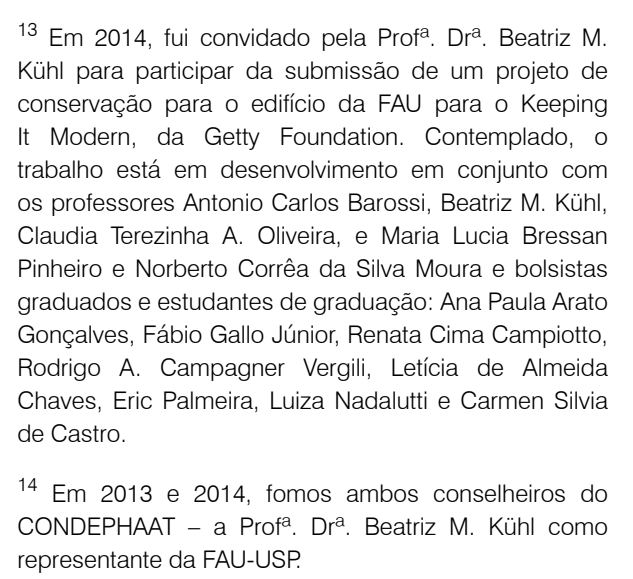

${ }^{14}$ Em 2013 e 2014, fomos ambos conselheiros do
CONDEPHAT - a Profa. D Pr. Beatriz M. Kühl como
representante da FAU-USP. 
Este capítulo pretende discutir de que forma o patrimônio cultural é contaminado pelo processo de valorização econômica que atinge o campo da cultura a partir da segunda metade do século XX. No caso espeć́fico do moderno, cabe analisar até que ponto seu reconhecimento como patrimônio é condicionado por novas políticas - já que no mesmo momento.

A segunda metade do século XX, nesse sentido, será estudada a partir de algumas abordagens que poderão esclarecer em que contexto o reconhecimento e a preservação da arquitetura moderna aconteceram: o pos-moderno e sua relação com a cultura de massa, o questionamento da arquitetura e urbanismo racionalistas, e as diretrizes contemporâneas referentes à preservação de patrimônio cultural.

As proposiçōes discutidas por Alois Riegl (1858-1905) no início do século XX sobre os valores dos bens culturais e a ampliação do campo a eles relacionado, que deixou de se ocupar apenas dos edifícios "grandiosos", fizeram com que obras anteriormente não consideradas passassem a ter valor cultural. Essa ampliação foi ainda mais evidente com os estudos de patrimônio industrial e moderno - que trouxeram consigo a questão da habitação e dos edifícios com programas cotidianos, que raramente seriam considerados patrimônio antes das formulações de Riegl e que se consolidam como tais na segunda metade de século XX.

Portanto, o patrimônio cultural passou a ter, após a Segunda Guerra, lugar de destaque na cidade e na cultura, de forma geral. Entre outras consequências, houve uma série de ações que supostamente seriam de valorização, mas que foram de encontro às recomendações contemporâneas de preservação e conservação: "[...] reconstituiçōes histôricas" ou fantasiosas, demoliçöes arbitrarrias, restauraçoos inqualliticaveis tornaram-se formas de valorização correntes" (CHOAY, 2001, p. 214).

Não se trata, no entanto, de discutir a problemática geral de valorização cultural do patrimônio. A construção de identidade, a atribuição de valor os inventários são assuntos amplamente debatidos em diversos trabalhos. Entretanto, essa recente valorização econômica ainda merece aprofundamento no âmbito brasileiro. O que motivou tamanho interesse? De que modo a arquitetura e o patrimônio passaram a ser atores importantes nas principais políticas econômicas e urbanas? Quais foram as consequências desse processo? 


\section{Valor econômico do patrimônio}

Quando Françoise Choay escreveu A alegoria do patrimônio (1992), colocou em discussão as questões da indústria cultural com relação à preservação do patrimônio. Apresentou os grandes problemas que naquele momento colocavam em risco a preservação dos bens culturais, a partir de uma relação em que o valor econômico passava a ser soberano, sobrepondo-se a outras demandas de preservação. Mais de duas décadas depois, esse processo não se estancou. Pelo contrário, multiplicou-se e mostrou diversas facetas.

A relação entre patrimônio cultural e valor econômico é visceral. Não há texto que fale sobre patrimônio sem deixar de citar a questão da propriedade, das políticas de preservação, dos ônus e bônus econômicos do tombamento. São temas que sempre estiveram no centro da discussão e que se tornaram mais evidentes com a ampliação da abrangencila do "patrimônio cultural". Apesar de essa relaçáo tender a colocar o patrimônio cultural como um empecilho e fator de perda de valor econômico, o que se observa, nos últimos anos, e que a promoçáo dosses bens tem se tonado alividade conômica importante, não apenas pelo próprio pela intensificação das atividades periféricas.

Desse modo, o patrimônio cultural passa a uma condição de produto a ser explorado em amplos sentidos, com forte apelo comercial. Assim, aumenta-se o turismo, os serviços, o comércio em um processo que abrange diversas atividades relacionadas. Mas, como Choay (2001, p. 228) destaca: "Esse público é em geral enganado em massa pela indústria patrimonial, que - temos de admitir - na esteira da evolucão das sociedades industriais avançadas, tende a vender-Ihes ilusões à guisa dos valores prometidos". A autora reforça que por um lado, o destaque dado ao patrimônio cultura confere um reconhecimento jamais alcançado e, por outro, leva ao risco da autodestrução. No início dos anos 1990, são diversas as formas de intervenções danosas por meio de um processo de mediacão, de comunicaçáo superficial e de encenaçáo. Muitos dos aspectos apresentados são de luz, som, informação, venda de souvenires, locaçãa para publicidade Apesar de interferirem na percepcão do objeto, esses casos são, em grande parte, de fácil reversão.

Outros aspectos levantados interferem diretamente na "matéria", causando danos irrecuperáveis. São os casos de modernizações, alterações de uso e adaptações a normas de segurança (que tiveram um aumento considerável desde então). No caso da atribuição de novos usos, os programas propostos muitas vezes não levam em consideraçao as caracteristicas espaciais e materiais dos edificios. $O$ aumento do fluxo de pessoas em um edificio originalmente construido para um uso de menor intensidade. como uma habitação simples, pode gerar um abalo em suas estruturas, visto que inicial- mente não foram consideradas as cargas e vibrações de um público grande'. Outro tipo de intervençáo que ocorre de modo semelhante é o de propor novos usos incompatíveis alguns casos, nem sequer permitem a leitura do bem cultural.

Há ainda o problema das cidades de pequeno porte que passam a receber um movimento de visitantes incompativel com a sua infraestrutura, causando problemas que ultrapassam a questáo do patrimônio e interferem no cotidiano de seus moradores. Nesse sentido, a lógica e a economia do turismo podem se impor como única possibilidade, eliminando traços da cultura local em nome de uma oferta massificada de produlos e serviços, ou gesar um processo de elilizaçao, expulando madores do local para implantação de novos programas que atendam a esse novo fluxo de pessoas.

Essas questões estão relacionadas, também, a outro fenômeno da segunda metade do século XX: a cultura de massa. Muitas dessas intervenções são projetadas por um grupo de arquitetos com superexposição nos meios midiáticos - os chamados "Star Architects" Ou seja, ao valor reconhecido do patrimônio cultural soma-se o valor de uma grife, ampliando ainda mais a visibilidade do edifício. Em um grande número de casos, o bem cultural serve de mero suporte para a intervenção, submetendo seus valores aos interesses de uma nova arquitetura. Em vez de estabelecer uma relação respeitosa com as preexistências, essas intervencỗes as tratam como suporte para proespeitosa com as preexistências, essas intervençoes as tratam como suporte para projetos mirabolantes, que acabam se tornando protagonistas absolutos. Saao diversos os Madri, que foi instalado no antigo Hospital General de Madri, edifício de 1788 , ou a recente proposta de Zah hadid (1950-2016) para a nova sede do porto da Antúnpla, renova e amplia (e canibaliza!) uma estação de bombeiros abandonada.

Considerando esse contexto, a assinatura de um projeto passa a ter um valor simbolico e, consequentemente econômico, que Bourdieu discute em um trabalho sobre o mercado da moda. O autor questiona: [...] como continuar produzindo Chanel - objeto simbólico, marcado com o signo da randade pela assinatura - sem Chaprodutos Chanel Como confeccionar produtos Chanel que não sejam cópias nem falsificações, como se diz na pintura? O problema existe porque pretende-se fazer sem Chanel aquilo que beme existe porque pretende se fazer sem chanel aquilo que Chanel: não um simples produto substituto, capaz de roprodu Cir produs de acordo com os cinnones "criados" pelo "criador",
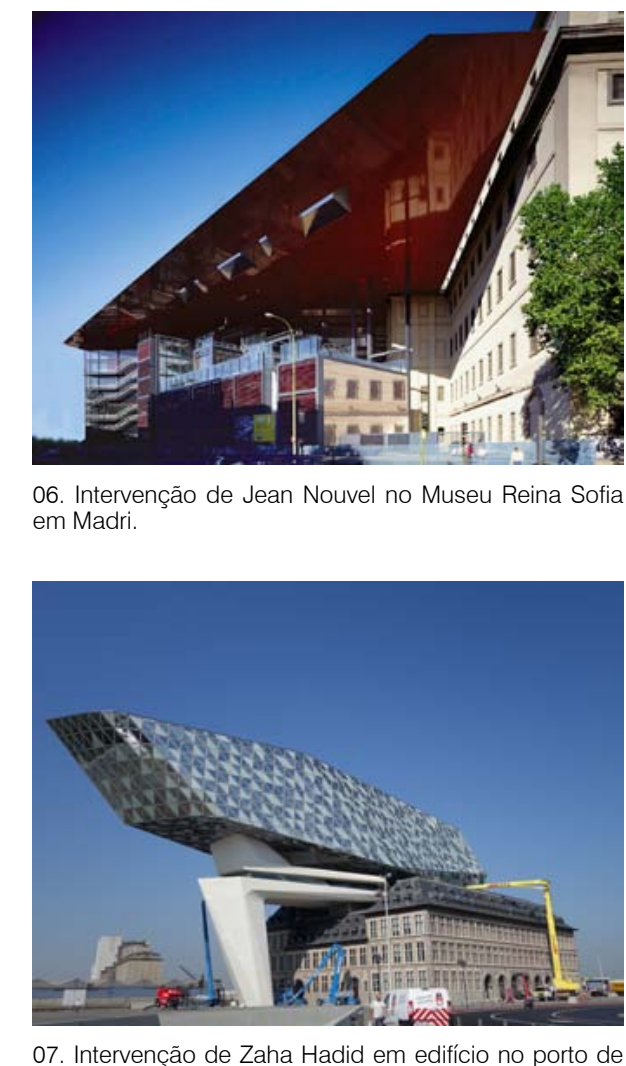

07. Interver
Antuerpiai. 
Sem entrar nas especificidades do campo da moda, na arquitetura, observa-se um desejo de perpetuar a assinatura, a grife, não apenas como uma possibilidade de preservar o que foi produzido, mas também como uma forma de continuar a produzi em nome de determinados autores, com a deliberada intenção de colher o bônus do capital simbólico e econômico dessa produção.

Outra forma de valorização econômica que passa a ser considerada é o aumento dos preços dos terrenos e dos imóveis no entorno de bens culturais. A recuperação de um edificio ou de uma área urbana acarreta, imediatamente, uma alta nos valores das propriedades. Um bônus indireto, mas que também merece atençaao, posto que en de decomposição de dinâmicas consolidadas nas áreas antes degradadas.

O que efetivamente interessa discutir neste trabalho é a interface entre preservação e as diversas formas de valorização econômica. Françoise Benhamou estuda essa relação na França e chama a atenção para as atividades econômicas que orbitam em torno do patrimônio a partir do final do século XX. O turismo e o comércio, evidentemente, são os que primeiro aparecem: " [...] le tourisme contribue au bien être local et au développement de senvices et permet des synergies avec d'autres secteurs de l'économie urbaine" (BENHAMOU, 2012, p. 65)

O problema não é apenas a bem-vinda utilização do patrimônio como importante participante das políticas públicas e urbanas, mas também de que forma essa participação se submete à lógica do mercado, colocando, invariavelmente, as questões pertinentes à preservação a serviço do ganho maior:

Savoir mettre en valeur le Patrimoine sans en surévaluer les retombées, tel est le défi que doivent affronter les défenseurs du Patrimoine s'ils souhaitent justifier le dépense publique et privée sans pour autant rédulie les stratégies patrimoniales â leur

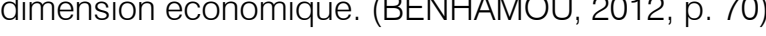

David Harvey ressalta, na mesma linha de argumentação de Choay, os problemas da valorização e de sua "[...] vulnerabilidade à manipulação do mercado de massa" (1992, p. 55)
"O pós-modernismo abandona todo sentido de continuidade e memória histórica, enquanto desenvolve uma incrivel capacidade de pilhar a historia e absorver tudo o que nela classifica como aspecto do presente" (HARVEY, 1992, p. 58). Assim, em contraponto à postura moderna de rejeitar qualquer historicismo, nesse momento há um resgate de estilos arquitetônicos do passado, usados de forma live, sem nenhum compromisso com os processos históricos. A produção pós-moderna está preocupada com as aparências superficiais.

Nesse amálgama de referências que o pós-moderno traz, há um resgate histórico que permite que:

[...] os arquitetos e projetistas urbanos podem sentir-se livres para citá-los na ordem que quiserem. A inclinação pós-moderna de acumular toda espécie de referências a estilos passados é uma de suas características mais presentes. Ao que parece, a realidade está sendo moldada para imitar as imagens da mídia. (HARVEY, 1992, p. 85)

Nesse sentido, a abordagem do "falso" feita por Cesare Brandi (1906-1988) contribui para a problematização dessa postura que aceita que novas construçês ou restauros se coloquem no lugar do original sem a distinção necessária entre o original e a nova obra.

Uma das primeiras questões levantadas por Brandi é que "[...] a falsidade se funda no juízo" (2004, p. 114). Portanto, não se trata de invalidar qualquer construção com seu valor inerente, mas de se fazer passar por outro:

$$
\begin{aligned}
& \text { [...] reconhece-se, assim, no juízo de falsidade um juízo proble- } \\
& \text { mático com o qual se faz referência às determinações essenciais } \\
& \text { que o sujeito deveria possuir e não possui, mas que, ao contrário, } \\
& \text { se pretenderia que possuísse, donde no juízo de falsidade se es- } \\
& \text { tabelece a não congruência do sujeito ao seu conceito e o próprio } \\
& \text { objeto é declarado falso. (BRANDI, 2004, p. 114) }
\end{aligned}
$$

O autor estabelece três situações do falso que sintetizam sua abordagem

1. Produção de um objeto semelhante a, ou reproduzindo, um outro objeto; ou, ainda, no modo e no estilo de um determinado
4Cesare Brandi ifoilistoriador de ate, fundadore diretor
do lostituto Centrale del Restauro, em Roma, no quad 


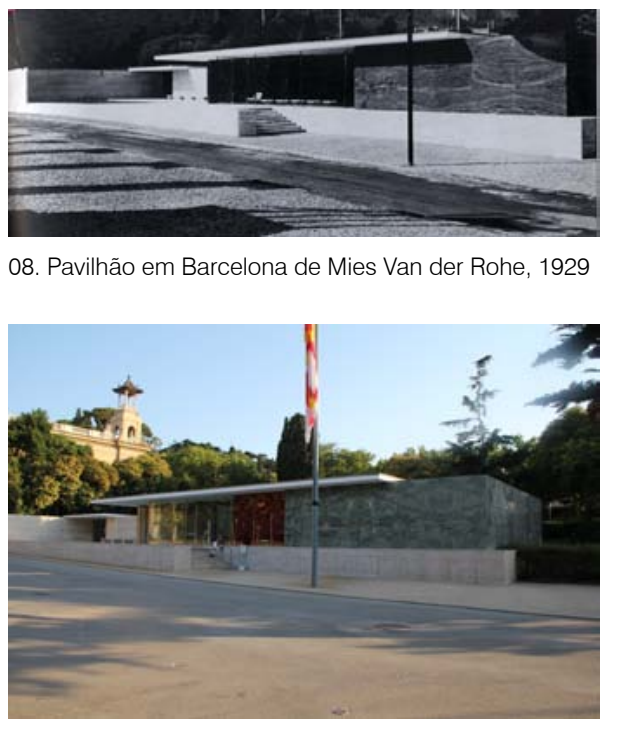

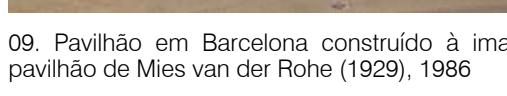

período histórico ou de determinada personalidade artística; para nenhum outro fim a náo ser uma documentação do objeto ou 0 prazer que dele se quer extrai

2. Produção de um objeto como referido acima, mas com o intento específico de levar outros ao engano a respeito da época, da consistência material ou do autor

3. Imissão no comércio ou, de qualquer modo, difusão do objeto, mesmo que não tenha sido feito com a intenção de levar ao engano, como uma obra autêntica, de época, ou de matéria, ou de fabricação, ou de autores diversos daqueles que dizem respeito ao objeto em si. (BRANDI, 2004, p. 115)

Publicada nos anos 1960, a Teoria da restauração de Brandi não estava mirando a preservaçáo do moderno, mas discutindo a preservaçáo de obras de arte em geral que evidentemente e de modo explíito inclui a arquitetura. Esses princípios contribuem para a discussão deste trabalho, já que diversos casos que serão abordados adiante se enquadram precisamente nas categorias acima. Estudar arquitetura não é apenas um exercício de estilo e de imagem. Trata-se também de analisar questões construtivas - que não são exclusividade do moderno, mas que ganham ênfase na produção do século XX - e de contexto. Assim, a busca pela imagem idealizada, que será discutida adiante, omite, em diversos casos, as questões de construção que, na atribuição de valor, são fundamentais. Em relação ao contexto, uma obra de arquitetura sempre estará relacionada com o seu entorno, seja ele urbano ou rural. Essa relação é parte indissociável da leitura de um edifício.

É evidente que a possibilidade de experimentar a espacialidade e a materialidade de obras que já não existem mais, ou que nunca foram construídas, é de grande interesse e tem um efeito didático de extrema relevância. Vivenciar o espaço de uma obra de arquitetura éma experiência única que até hoje ainda naao conseguiu ser substituida por outras representaçoes. ${ }^{\circ}$ O problema, como se verá adiante, é a ausência de informação que evidencie se tratar de uma cópia, ou uma interpretaçâo que busca dee Le Corbusier (1887-1965), emsos de Mies van der Rohe (1886-1969), em Barcelona

Orisco dessas acõos é de interferir na compreensão e na preservação daquilo dentemente aos amplos benefícios de se possuir um acervo de supostas obras de arte Se no campo das artes plásticas a ideia do falso já é compreendida como uma ação criminosa, na arquitetura essa leitura ainda não é clara. São numerosos os edifícios construídos à semelhança dos seus "originais" e que não são encarados como um problema de autoria e autenticidade. Pelo contrário, têm sido louvados como a possibilidade de fruiçáo de uma "arquitetura autêntica".

Uma hipótese para essa diferença de aproximação pode ser o valor econômico das obras e dos falsos. O mercado de arte cuida desses problemas que interferem nos valores das obras e, portanto, nos ganhos advindos de sua comercialização. No caso da arquitetura, essa valorizaçáo esłá ligada ao capital simbólco e aos ganhos econódivulgação de tais obras como publicações, vídeos e filmes.

No que diz respeito à "difusão do objeto", com ou sem a intenção de "levar ao engano" não cabe julgar a intenção dessas ações, mas tentar compreender seus reais objetivos, que de forma geral não estão alinhados com as diretrizes de preservação de patrimônio cultural, mas que respondem às demandas de atividades econômicas importantes.

Alguns documentos sobre o tema da preservação permitem uma leitura enviesada e têm sido utilizados para amparar ações bastante discutíveis.

A Convenção para a Proteção do Patrimônio Mundial, Cultural e Natural realizada pela Unesco, em 1972, confirma não apenas a ampliação do campo do patrimônio, mas também sua abrangência. A questão da preservação passa a ser de âmbito global. Considera-se a necessidade de que a "coletividade internacional" tome parte no processo de preservação. Estabelece a criação de um "[...] sistema internacional de cooperação e assistência, destinado a auxiliar os Estados-parte na convenção nos esforços que desenvolvam para preservar e identificar este patrimônio"

Após a Convenção, foi divulgada a Lista do Patrimônio Mundial?. Os bens que nela constam passam a ter direito a assistência financeira internacional, a partir de um fundo constituido para esse fim. Entre as contrapartidas estâo a obrigação de divulgar os processos, de apresentar planos de gestáo e de conservar sistematicamente os bens. O efetto inedaro fol a contida dos administradores públicos para obter o título de Patrimônio Mundial, abrindo uma possibilidade de aporte financeiro para a recuperação dos centros históricos e gerando um aumento significativo de turistas - com toda a valorização econômica que isso acarreta. Em diversos casos, esse processo levou, também, a uma supervalorização do entorno imediato, que teve como consequência a elitização de algumas áreas, conforme colocado anteriormente. No entanto, essa valorização não está exclusivamente relacionada ao patrimônio cultural, mas ocorre também em áreas urbanas mais degradadas ou esvaziadas por questões diversas. Os subúrbios das grandes cidades, com conjuntos habitacionais e edifícios industriais, também já sofrem com esse processo, com o crescimento das manchas urbanas.

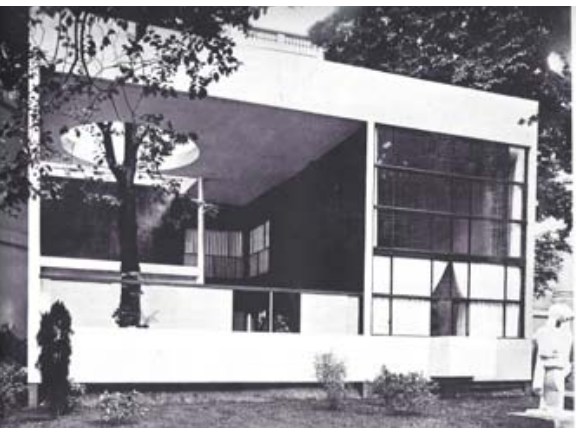

10. Pavilhăo Esprit Nouveau, em Paris, de Le Corbusier

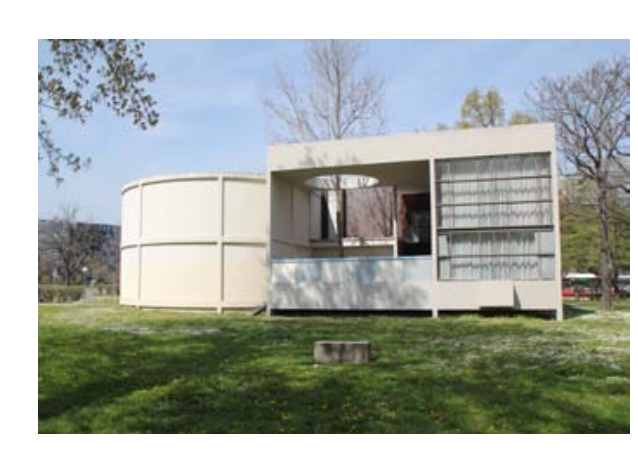

11. Pavilhäo em Bolonha construido à imagem do
Pavivhao Esprit Nouveau, de Le Corbusier (Paris, 1925)
1997

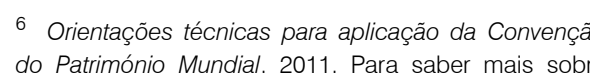
as questöes sobre o Patrimônio Mundial da UN UNESC

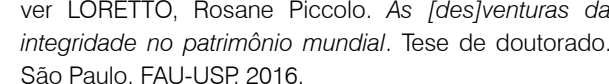
1 Idem. Atrigo 11. Parágrátio 2 


\section{Pós-moderno}

A leitura que David Harvey faz sobre o moderno e o pós-moderno contribui para esclarecer alguns dos novos olhares sobre a cidade e o patrimônio a partir da segunda metade do século XX.

Harvey ratifica a ideia de que uma das principais características do pós-moderno é o questionamento da assertividade e da racionalidade do moderno. Os pós-modernos aceltam e propoem a fragmentaçao e a elemenidade, o provisortio, a identidade cultura com todas as suas nuances regionais, permitindo a sobreposição de estilos e de linguagens. Uma grande liberdade em contraponto aos concellos modernos de universaque, segundo Habermas, foi um dos principais fatores que levou à sua decadência:

A utopia de uma forma de vida preconcebida, que já inspirara os projetos de Owen e Fourier, não se pôde encher de vida. E isto não apenas por causa da apreciação irremediavelmente subestimada da multiplicidade, complexidade e mutabilidade dos modernos mundos da vida, mas tambem porque as sociedades modenizadas, com suas conexoes sistemicas, excedem a dimensáo que a fantasia do planejador acaso pudesse medir. As manirestaçoes hoje evidentes de cirse na arquitetura moderna remonlam menos a una crise dela propria e, mais ao fato de que ela se deixou voluntariam (HABERMAS, 1987, p. 122; grifo do autor.)

Do ponto de vista de linguagem, ainda segundo Habermas (1987, p. 120) "[...] o movimento moderno contrapõe a exigência de um estilo que não se limite a vincar as construções de aparato, mas que impregne a práxis cotidiana"

O discurso moderno do início do século XX se afirma como definitivo, universal e, portanto, anti-historico. Não estaria sujeito ao envelhecimento, à caducidade e assim não faria parte do ciclo de estilos históricos.

Assim, segundo Harvey (1992, p. 45),

[...] as torres de vidro, os blocos de concreto e as lajes de aço que pareciam destinadas a dominar todas as paisagens urbanas de Paris a Tóquio e do Rio a Montreal, denunciando todo ornamento como crime, todo individualismo como sentimentalismo e todo romantismo como kitsch, foram progressivamente sendo substituídos por blocos-torre ornamentados, praças medievais e vilas de pesca de imitação, habitaçôes projetadas para as necessidades dos habitantes, fábricas e armazéns renovados e paisagens de toda espécie reabilitadas, tudo em nome da defesa de um ambiente urbano mais "satisfatório".

Há de se compreender que, em um movimento de negação do antecessor direto, os pós-modernos se esforçaram por contestar grande parte das premissas modernas ${ }^{8}$, passando por cima de questões que foram essenciais e que inclusive serviam de base para o pós-moderno. Harvey reconhece que há importantes avanços nas propostas modernas, principalmente no que diz respeito às questões urbanas e de habitação. Do ponto de vista da arquitetura, os pós-modernos absorveram grande parte das realizações modernas, em que pese a utilização de uma outra estética - uma alteração substancialmente superficial.

Nesse mesmo momento, outro dogma moderno, o urbanismo, também é duamente atacado, com o decreto do fim dos grandes planos e da cidade racionalista. O novo olhar propóe abordagens pluralistas e organnicas, "[...] colagem de espaços e misturas altamente diferenciadas" (HARVEY, 1992, p. 46). Harvey diferencia claramente ções urbanas com abordagens mais sensíveis às questões locais e de preexistência.

\section{Patrimônio e cidade}

A relação entre patrimônio e desenvolvimento urbano ganha destaque no Congresso do Patrimônio Arquitetônico Europeu (Amsterdã, 1975). Nessa oportunidade é proposta a "conservação integrada", ou seja, a relação essencial entre os projetos urbanos, politicas econômicas e patrimônio cultural. Vale destacar algumas questoes le-
vantadas pelo Congresso que confirmam a preocupação com a preservação, mas que vantadas pelo Congresso que confirmam a preocupação com a preservaçáa, mas ambém geram, como consequência imediata, políticas culturais questionáveis.

[...] d) a conservação do patrimônio arquitetônico deve ser considerada não apenas como um problema marginal, mas como objetivo maior do planejamento das áreas urbanas e do planejamento físico territorial [...]

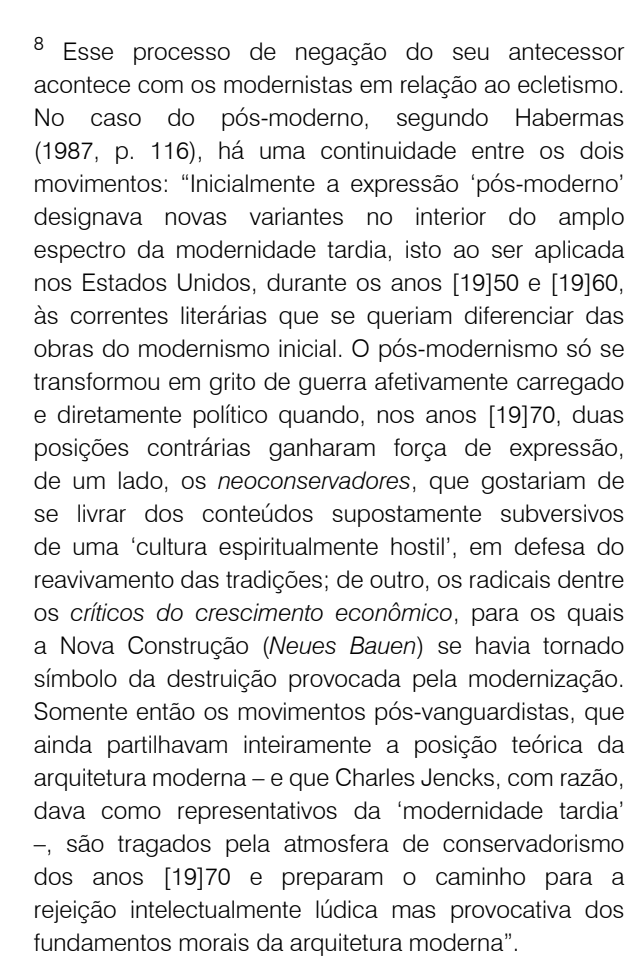



histórico, uma ajuda financeira adequada deve ser colocada à disposição dos poderes locais e dos proprietários particulares: além disso, para estes últimos, incentivos fiscais deverão ser previstos [...]

j) devem ser encorajadas as organizações privadas - internacionais, nacionais e locais - que contribuam para despertar o interesse público [...] (CURY, 2000, p. 200)

Os trechos mencionados evidenciam, portanto, o interesse na inserção do patrimônio nas políticas públicas urbanas e sociais, mas também dentro de uma lógica de mercado que não necessariamente é danosa, desde que bem regulada ${ }^{9}$.

Algumas diretrizes são estabelecidas no sentido de organizar as questões referentes às cidades e ao patrimônio: "[...] não basta sobrepor as regras básicas de planejamento às regras especiais de proteção aos edifícios históricos, sem uma coordenação" (CURY, 2000, p. 200).

A fim de evitar os processos de elitização, estabelece ainda que:

[...] para evitar que as leis do mercado sejam aplicadas com todo rigor nos bairros restaurados, o que teria por consequência rigor nos bairros restaurados, o que teria por consequência evasáo dos habilantes, incapazes de pagar aluguêis majorados, e necessária uma intervençáa dos poderes públicos no sentido do estabelecimento de politicas economicas destinadas às habitaçoes sociais. As intervençoés financeiras podem equilibrar-se entre os incentivos à restauraçáa concedidos aos proprielários, através da fixaçâa de tetos para os alugueis e da alocação de indenizaçoes de moradla aos localários, para dim nuir ou mesmo guéis. (CURY, 2000, p. 206)

A recorrente relação da preservação do patrimônio e da elitização de áreas urbanas traz uma questão essencial para esta discussão. É evidente que um processo de qualificação urbana acarreta um movimento no mercado imobiliário e a consequente valorização da terra e dos imóveis e, possivelmente, a expulsão de camadas sociais menos favorecidas. Essa questão, que deve ser cuidadosamente estudada, não está ligada à preservação em si, mas à ausência de outras políticas públicas que mantenham a população residente nesses locais. Políticas de oferta de habitação e locação social e de isenção fiscal devem se sobrepor às lógicas de mercado, sendo condicionantes para o desenvolvimento de projetos de qualificaçãa $0^{10}$.

A intervenção no centro de Bolonha, nos anos 1960, foi paradigmática no senIido de se obter um orimo resultado de qualificação urbana em consonância com poltilaboração da Carta de Amsterdã (1975).

Nos anos 1950 há, na Itália, uma grande movimentação pela preservação dos "centros históricos" e um olhar crítico para o crescimento do mercado e da especulação imobiliária"1. Bolonha, cidade da Emilia Romana, teve historicamente uma forte presença da esquerda em sua gestão - que trazia a ideia de uma cidade mais democrática menos desigual'

O projeto para o centro da cidade, desenvolvido por Pier Luigi Cervellati (1936) e Roberto Scannavini' ${ }^{13}$, tinha por princípio reverter um processo de destruição dos cenda Itália
as autores partem da compreensão de que o desenvolvimento econômico da Itália

[...] ha modificado profundamente la ordenación territorial preexistente $y$, en particular, ha relegado a los centros históricos (que eran el soporte de aquella ordenación) a ser abandonadas - en las áreas "marginales", sub-desarrolladas - o bien a ser objeto de inversiones especulativas de distinto tipo en las áreas congestionadas. (CERVELLATI, 1976, p. 1)

A discussão não é apenas colocada no sentido da preservação do patrimônio e da qualificação do centro, mas também aborda um sistema mais abrangente que inclua discussões sobre

Foi estabelecida uma área de intervenção, os edifícios foram inventariados segundo critérios tipológicos que foram a base para a definição de seus novos usos. A proposta teve como princípio a possibilidade de conservação da morfologia urbana: " [...] se ha considerado el problema de la forma urbana en su totalidad, analizándola como una organización dialéctica entre la permanencia de instalaciones y organismos originarios y los sucesivos cambios morfológicos" (CERVELLATI, 1976, p. 20).

Um discutível plano de conservação dos imóveis foi traçado, já que foram determinados critérios de intervenção que permitiam construções ou complementos que
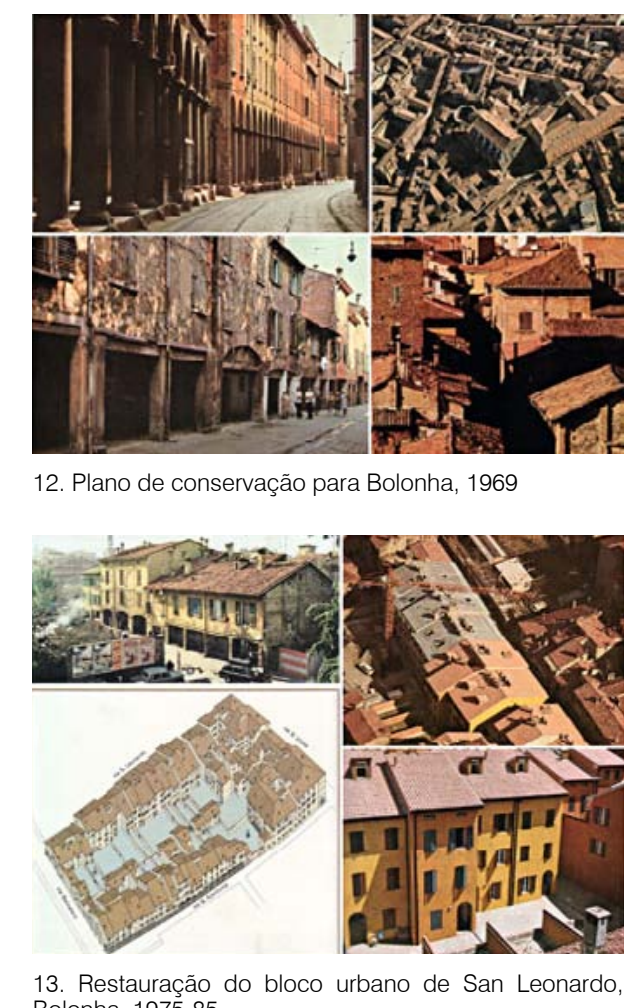

133. Restauracäo do
Bolonha, $1975-55$

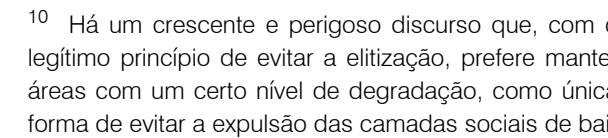
Toma de
xa renda.

"Em 1958, Italo Calvino (1923-1985) escreve o romann.

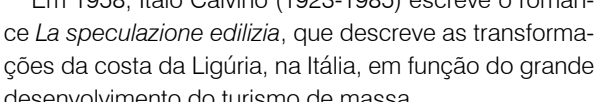

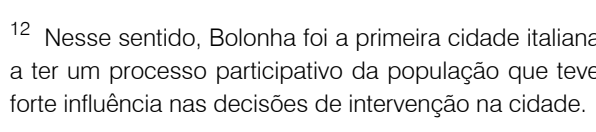
${ }^{13}$ Esse projett teve como base um profundo estudo so-
bre o centro de Bolonha desenvolvido na Universidadede

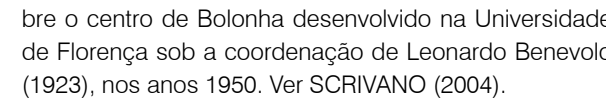




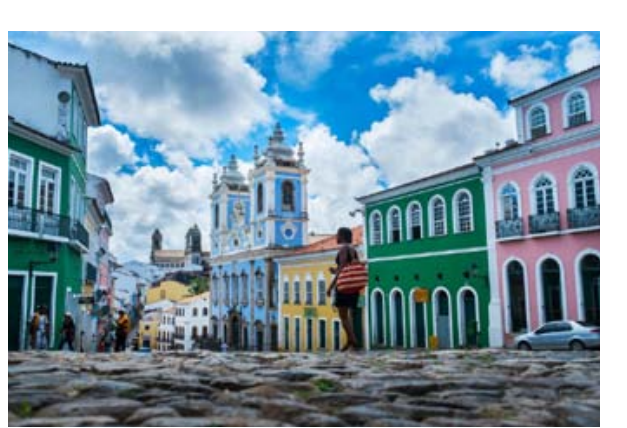

15. Pelourinho, Salvador, após a intervenção

14 Nos anos 1980, o centro de Bolonha passa a ser alvo
da especulacăo e do mercado imobiliario, e parte do

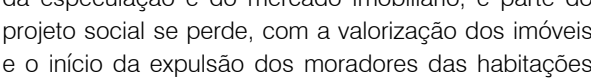
sociais propostas no plano de Cervelatti.
Ver: SCRIVANO (2004); FREGOLENT (2008). 15 Para saber mais ver LETE, Rogério Proença Contrausos da cidade - Lugares e espaço publico
na experiência urbana contemporânea. Campinas
Editora da Unicamp, 2004; e NOBBE, Eduardo $A$ C. Intervençöes urbanas em Salvador: Turismo
"gentrificąăa" no processo de renovacăa urbana do
Pelourinho. X Encontro Nacional da Annur. 2003. consolidassem uma morfologia urbana uniforme - no entanto, esses critérios não serão aprofundados neste trabalho. A questão principal que se coloca aqui e a possibilidade uma politica integrada de preservação e desenvolvimento urbano, econômico social. Para atingir o objetivo social, foram estabelecidas três diretrizes: constituição um patrimônio público; subsídio nos financiamentos e organização e gestão dos serviços sociais. O resultado foi, a princípio, bastante satisfatório tanto do ponto de vista da qualificação do centro urbano, como da política social de evitar um processo de elitização e expulsão dos habitantes da área central.

The policies for the city centre that Bologna's Communist administration carried out in the late 1960s and early 1970s drew wide international attention at the time of their implementation. They were seen as an ambitious program of urban preservation whose aims were to avoid both the physical destruction of the city centre and the expulsion of the original inhabitants. The example of Bologna was widely circulated, at least in Europe; it enjoyed a longlasting popularity among planners, architects, urban geographers, and those sectors of the public opinion that were more sensitive to the safeguarding of historical cities. (SCRIVANO 2004, D. 34)

Diversos processos de qualificação de centros urbanos tiveram a proposta deliberada de valorização econômica, sem o cuidado com a população local. Os projetos de restauro tratam os conjuntos históricos como cenários, desconsideram qualquer possibilidade de incorporação das pessoas e das práticas locais em nome da construção de uma imagem da cidade histórica e dos recursos e atividades que esse tipo de proposta traz No Brasil, casos como o do Pelourinho, em Salvador (BA) e do Bairro do Recife, no Recife (PE), são paradigmáticos nesse sentido. Ambos, com do especificidades, eram bairros centrais que passaram por um processo de degradação que mantinham de forma precária uma população de baixa renda mas principalmente, uma produção cultural bastante relevante. Em ambos os casos, o suposto restauro e qualificaçąo urbana, com a construção de um cenário "a la cidade histórica". levaram à expulsão das pessoas e de suas práticas, criando uma situação artificial, que atend a uma ideia fetichista da cultura do Nordeste brasileiro ${ }^{15}$ como pinturas sem relação com a morfologia arquitetônica de suas edificações e reconstruções em estilo. Mais do que a arquitetura e a cidade esses processos constroem uma cultura local falsa, que se utiliza da cultura vernacular para construir algo parecido, mas carregado de ap , que somercial que acaba interferindo na essência da cultura local como é o caso do Olodume de Carlinhos Brown, em Salvador, e do mangue beat e Chico Science, no Recife.
Antes de ser discutida pelos pós-modernos, a relação entre patrimônio construído os autores que refletiam sobre a preservação do patrimônio. Gustavo Giovanonni (18731947) aborda a questão da ambiência urbana desde os anos 1910 - cujos textos foram base para a Carta de Atenas para Restauração de Monumentos Históricos (CURY 2000) de $1931^{16}$

Giovanonni defende a necessidade de uma conservação que não inviabilizasse a vida contemporânea na cidade, com a clareza de que algumas ações deveriam ser fruto da ponderação entre a modernização e a preservação do patrimônio. Entende que as areas consideradas antigas, com um valor a preservar, deveriam fazer parte dos planos diretores e se articular com os novos sistemas e expansões urbanas. Em alguns casos, esclarece que a preservação do tecido urbano deveria se sobrepor a ações modemizadoras, as quals poderiam ter soluçós altemativas. Em outros, propõe o "desbastamento": demoliçoes especificas no tecido urbano que viabilizariam intervenções modernizadoras, desde que fossem previamente estudadas e feitas com rigor. Tambem desenvolve, de modo pioneiro, o concelto de ambiência, do entorno que qualifica o parimonilo cultural. Estabelece, portanto, relaçoes essenciais entre os tecidos urbanos e os monumentos para compreensão da cidade como um organismo único ${ }^{18}$

A Carta de Veneza, de $1964^{19}$, também aborda a questão da relação dos monumentos e de seu entorno nos seus artigos 6 e 7 :

Artigo $6^{\circ}$ : a conservação de um monumento implica a preservação de um esquema em sua escala. Enquanto subsistir, o esquema tradicional será conservado, e toda construção nova, toda destruicão e toda modificação que poderiam alterar as relações de volumes e de cores serão proibidas.

Artigo $7^{0}$ : o monumento é inseparável da história de que é testemunho e do meio em que se situa. Por isso, o deslocamento de todo o monumento ou de parte dele não pode ser tolerado, exceto quando a salvaguarda do monumento o exigir ou quando o justificarem razōes de grande interesse nacional ou internacional. (CURY, 2000, p. 93)

final da Segunda Guerra foi um momento crucial na discussão sobre as possíveis novas abordagens urbanas, principalmente em função da necessidade de pensar as açoes para reverter a situação das cidades devido à destruiçáa causada pela guerra. Nesse sentido, o discurso da segunda geração de arquitetos moderno ${ }^{20}$.

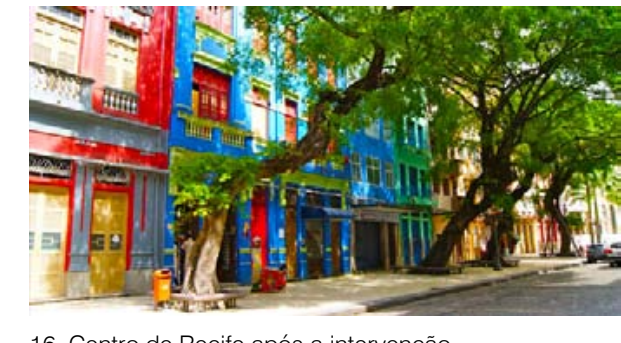

Documento elaborado durante o Primeiro Congresso
hternacional de Arguitetos e Técnicos de Monumentos

Desbastamento:"....] conjunto de pontual tarterioes, propostos seguindo a 'fibra' do bairro de salubridade, restituindo 'ar e luz', e de liberar

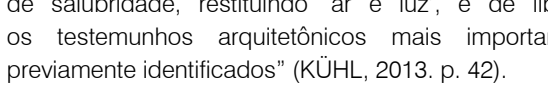

${ }_{18}$ Apesar do discurso se encaixar precisamente na

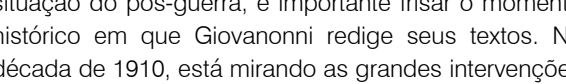

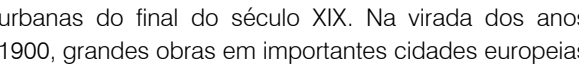

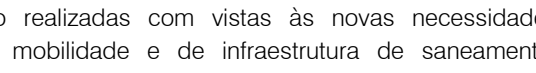

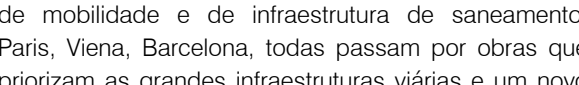
priorizam as grandes infraestruturas vírias e um novv ABRAL, Renata. A noçäa de "ambiente"en em Gustar

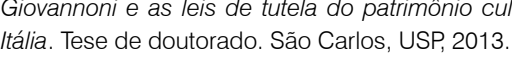

19 Documento final do II Congresso Intermacional de
Arquitetos e Técnicos dos Monumentios Históricos.

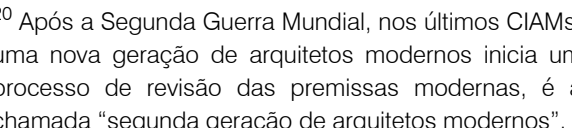



no VIII CIAM - The Heart of the Cities ${ }^{21}$, incorpora a discussão sobre ambiência e vida
na cidade existente, rompendo com as propostas urbanas estabelecidas pela Carta de Atenas, de 1933. Em 1951 é publicado um sumário do congresso. O próprio título indica o sentido para o qual a segunda geração de arquitetos modernos caminha. $A$ recuperação dos centros destruídos pela guerra, a consideração de que os centros históricos são essenciais para a vida na cidade, a necessidade de compreensão do contexto, como premissa de trabalho como coloca $J$ L S Sert, no primeiro texto do livro Centri per la vita dela comunità: [...] gli architetti e gli urbanisti si sono trovati di fronte al difficile
compito di stabilire i piani regolatori delle zone centrali di città bombardate e si sono ben presto accorti che queste zone richiedono un trattamento speciale, che i precedenti stud urbanistici non avevano mai considerato. (SERT, 1977)

Ernesto Nathan Rogers (1909-1969), um dos principais arquitetos da segunda geração, teve participação essencial na discussão sobre arquitetura moderna na segunda metade do século XX. Escreveu diversos textos a respeito, vários deles compilados no livro Esperienza dell'architettura (1958). Sua abordagem é feita com base na leitura das tradições e da vida nos centros das cidades - cuore della città. Enfatiza a questão da cultura e tradicão locais e da inviabilidade do homem universal, proposto pelos arquitetos modernos da primeira geração.

[...] para los diseñadores culturalistas, antes del movimiento moderno, el problema de la inserción de las propias obras en las preexistencias ambientales coincidía con el de la imitación estilistica, con la cual creían continuar la tradición, sin advertir que se trataba sólo de un formalismo vacío de todo contenido vital. En los primeros diseñadores del movimiento moderno el impulso de rebelión contra ese estado de cosas debía necesariamente convertirse en una áspera polémica contra el pasado, al punto de que la inserción consistía en un acto de violencia contra las preexistencias y, en el mejor de los casos, se resolvía como un contraste armónico entre los diversos aspectos de la belleza cada uno autónomamente válido. Nosotros, que tratamos hoy de llevar adelante las premisas de estos precursores del Movimiento Moderno que, por las diversas condiciones en que actuaron, no pudieron entonces desarrollarlas del todo, consideramos el problema de las preexistencias ambientales con renovada atención. Ya no nos basta que una obra exprese nuestra época, si no afirma la plenitud de los valores contemporáneos insertándolos en la sociedad y en el espacio, enraizándolos profundamente en la tradición. (ROGERS, 1965, p. 98)

Sem citar ou explicitar o seu interlocutor, Rogers está partindo dos mesmos princípios estabelecidos por Giovanonni²: a necessidade de intervenções nas cidades com o cuidado de preservar seu caráter e seu patrimônio. Entende que uma eventual radicalização na preservação possa engessar a cidade, sob o risco de inviabilizar a vida contemporânea. Tenta, dessa forma, compreender o que seria a justa medida para a cidade que não fosse nem a "cidade ideal moderna" nem "múmias embalsamadas",

[...] en la planificación, el conservar y el construir son momentos distintos de un mismo acto de consciencia, porque uno y otro están supeditados a un mismo método. La conservación resulta absurda si no se la entiende en el sentido de actualización del proceso histórico: se trata de clarificar en nosotros el significado de la historia. (ROGERS, 1965)

Nesse mesmo período, Aldo Rossi (1931-1997) escreve A arquitetura da cidade (1964), uma das obras que marcam a ruptura dos ideais da cidade moderna dos CIAM. O centro da discussão colocada diz respeito à forma de olhar a cidade existente. Estabelece outro modo de ler o tecido urbano e os monumentos. Para essa interpretação dos "fatos urbanos"23, entende que se deve considerar sempre as permanências ${ }^{24}$ e as "[...] forças que estão em ação de modo permanente e universal" (ROSSI, 2001 p. 23).

Rossi faz um recorte claro na sua leitura: fará o estudo a partir da arquitetura e da geografia - que é exatamente o que ele denomina "permanência". Portanto, não
dará ênfase às questões sociais e políticas, mas à questão da arquitetura, cidade e dará ênfase às questc

O alinhamento de Rossi com as posturas de Rogers é evidente. Ele amplia a noção dos valores da arquitetura e da cidade:

[...] todos nós pensamos nos valores que permaneceram e devemos constatar que, embora esses valores tenham uma conexāo na materia e seja esse o único dado empírico do problema, também nos referimos a valores espirituais. Nesse
22 Giovanonni nano é citado na elaboracăón da Carta de
Venezza apesar de suas proposstas ainda serem atuais estarem claramente refletidias na carta. O autor fo gnorado por décadas por ter
simpatizante dos governos tascistis

${ }^{23}$ Rossi usa o termo "tatos urbanos" para todos os

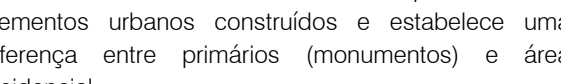
24 Para estabelecer uma letitura das construgóes do

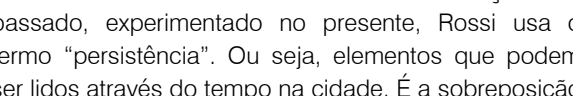

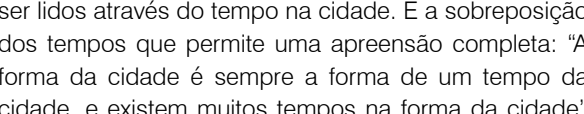
cidade, e existen
(Rossi, 2001). 

dele. (ROSSI, 2001, p. 16)

Rossi utiliza, para os fatos urbanos o termo "obra de arte". Mesmo termo utilizado por Brandi em sua Teoria da restauração ${ }^{25}$. Nesse sentido, ambos entendem que o objeto de estudo trata da matéria que suporta o valor de obra de arte. Rossi entrelanto, compreende que a cidade não pode ser lida apenas a partir das obras de arte. Essa leitura deve ser mais abrangente: "[...] o todo e mais importante do que as partes e que somente o fato urbano en sua totalidade, portanto também o sistema viário constituem essa totalidade." ${ }^{26}$ (ROSSI, 2001, p. 24)

As discussões estabelecidas tanto por Rogers como por Rossi no campo teórico foram fundamentais para a desconstrução do conceito de cidade funcional. Abriram novas perspectivas para os projetos arquitetônicos e urbanos que colocam a preexistência como protagonista das novas propostas. Exigem, de certa forma, que as novas inserçōes urbanas estabeleçam um diálogo com a cidade - 0 que vai se mostrar uma questão de difícil resolução, conforme será discutido adiante.

No campo da preservação, a segunda metade do século XX é também o momento em que o conceito de restauro-critico ${ }^{27}$ se consolida, principalmente com a Carta de Veneza. A partir de textos de Cesare Brandi e Roberto Pane (1897-1987), compreende-se a necessidade de leitura especifica para cada caso a ser tratado. Desse modo, a Carta náo estabelece regras igldas de inten doça, mas recom Seguces com base em estudos realzados e valores apreendidos do proprio objeto. Segundo Brand

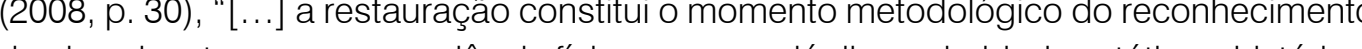
com vistas a sua transmissão para o futuro".

A Carta também ratifica a ampliação do campo do patrimônio cultural, sem hierarquizá-los, conforme estabelecido no seu Artigo 10:

${ }^{25}$ Brandi, na Teoria dar restauraçäa, considera o coniunto
urbano como um todo monumento e o assimila, do
ponto de vista do método, às obras de arte 2004 . ponto de vis
106-107) ${ }^{26}$ Brandit também discute a questáa da ambieincia
cuando trata da restauraçąa preventiva. Entende que

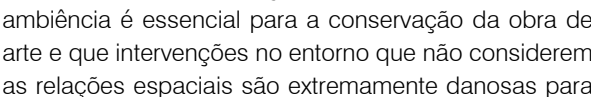
as relaçoseas easana

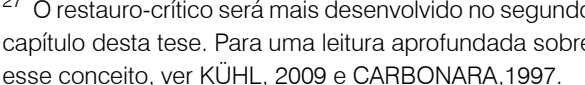

A noção de monumento histórico compreende a criação o sitio urbano ou rural que dá testemunho de uma civilizaçâao particular, de uma evoluçâa só às grandes criaç̃os, mas também às obras modestas, que tenham adquirido, com o tempo, uma significação culturat (CURY, 2000, p. 92)
Observa-se que as recomendações da Carta pretendem ser abrangentes e flexíveis para serem aplicadas em diferentes escalas.

Nesse momento, há uma certa convergência das discussões colocadas por Giovanonni e Brandi e pelos arquitetos modernos em relação à cidade. Entretanto, essa aproximação acontece essencialmente na questão do valor a ser resgatado e preservado has cidades. Para os modernos, o valor simbólico e social; para os que estudam a preservação, há um valor mais concreto: questōes figurativas e de materialidade. O trauma das destruiçócs e a demanda de reconstrução da vida exigem uma tomada de 作 lacunas?

"[...] seremos tanto más modernos cuanto más capaces seamos de conectarnos con las tradiciones, y cuanto más armonicen nuestras obras con las preexistencias ambientales" (ROGERS, 1965, p. 148). Verifica-se, no entanto, que a firmeza com que Ernesto Rogers se posiciona a respeito das novas construções em tecidos históricos se
desfaz rapidamente quando nos aproximamos dessa discussão nos anos 1950 e 1960. É evidente a dificuldade de consenso sobre o assunto.

Para os arquitetos modernos, qualquer tentativa de estabelecer diretrizes e criterios que "harmonizem" as novas edificaçōes com o território urbano gera distorções e não é possível abrir mão dessa premissa.

Para os que trabalhavam as questôes da preservação, a ideia do conjunto urbano harmônico é central. Tentam, nesse sentido, estabelecer princípios para as novas inserçōes e evidenciam a dificuldade de trabalhar com a arquitetura moderna dentro desses contextos.

Em 1956, na revista L'Architettura Cronache e Storia, Brandi escreve um artigo intitulado "Processo all'architettura moderna" no qual expõe de que forma, desde o tevas obras inseridas nos tecidos urbanos trataram de cuidar de uma relação com as preexistências

Para isso, atribui a Bruneleschi (1377-1446) uma nova leitura do espaço urbano que "[...] con la scoperta della prospettiva rese possibile la nuova spazialità della pittura della scultura e dell'architettura, come un ordine nuovo nello spazio stesso dove si svolge la vita umana" (BRANDI, 1956)

A partir de uma leitura da morfologia da cidade é que Brandi estrutura sua argumentaçäo. Percorre as posturas adotadas desde o "cinquecento" alé os modernos para demonstrar que, independien visuais, através da perspectiva, sempre foram respeitadas. 
Ao escrever sobre a arquitetura moderna, Brandi já indica em um dos subtítulos do texto ("La spazialita antiprospettica dell'architettura moderna") qual a questão que pretende levantar. Deixando claro seu respeito pela produção moderna: interpela, entretanto, a sua relação com os tecidos históricos e se pergunta:

[...] perché mai dovrebbe essere negato alla nostra epoca $d$ lasciare una traccia di sé in architettura, e di inserirsi accanto alle altre testimonianze del passato, cosi come è stato fatto dal Medioevo al settecento? Non esiste forse, oggi, un'architettura moderna che, superata la fase incubatrice del primo novecento ormai ha bene acquistato il diritto di essere considerata come arte? (BRANDI, 1956)

Como resposta a seu próprio questionamento, Brandi considera que a arquitetura moderna não pode ser inserida em um contexto histórico sem destruí-lo e se autodestruir. Entende que os princípios da perspectiva negam os da arquitetura moderna: "[...] perché un'opera d'arte si distrugge ove venga ad accettare delle condizion spaziali che la negano, e altreftanto distrugge in ragione di quello che negando afferma" (BRANDI, 1956).

Brandi entende que a arquitetura moderna não faz nenhum sentido se for lida do ponto de vista da perspectiva, que é como ele lê os tecidos históricos existentes. A crítica aqui é dirigida a uma determinada expressão do moderno, a posturas de vanguardas modernas que se manifestam pelo edifício isolado no terreno, e pelo fim da rua corredor

Quando Bruno Zevi (1918-2000), no mesmo número da revista, responde a Brandi, em artigo intitulado "Visione prospettica e spazio-temporalità nell'architettura moderna", defende alguns princípios que ele próprio irá rever anos mais tarde. Seu texto pretende desmontar a argumentação de Brandi, ponto a ponto. Critica a leitura de Brandi que se restringe à questão da perspectiva na cidade e esclarece a respeito da arquitetura moderna:

[...] la visione spazio-temporale moderna stimola la creatività dell'ultimo cinquantennio di storia, ma non si riferisce soltanto ad essa: costituisce un modo di vedere dinamico, un nuovo principio di visione che surroga quello prospettico ed è applicabile a tutta l'architettura presente e passata. (ZEVI, 1956)
Zevi afirma, ainda, que "[...] quando l'architettura contemporanea ripete i principi prospettici, è lesiva all'ambiente più di ogni 'interruzione' sinceramente moderna", e não deixa de reconhecer que são poucas as obras modernas bem inseridas nos contextos históricos, mas que isso acontece porque

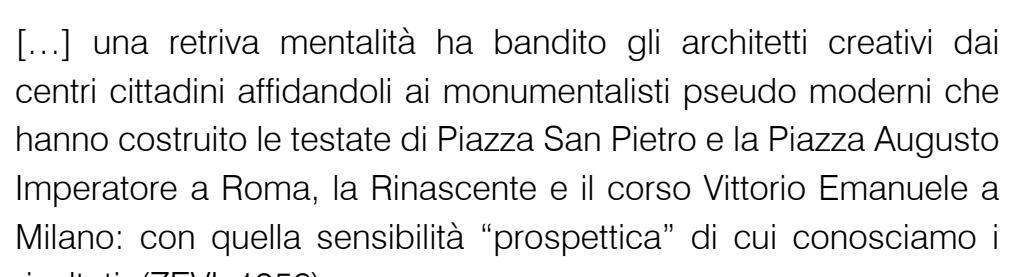
le testate di Piazza San Pietro e la Piazza Augusto a risultati. (ZEVI, 1956)

Toda essa argumentação contra Brandi não significa uma proposta clara de como trabalhar a questão dos centros históricos. Pelo contrário, seu artigo termina exatamente afirmando que essa ainda é uma questão aberta.

Voltando ao tema dez anos depois, na mesma revista, em 1965, Zevi escreve o artigo "Contro ogni teoria dell'ambientamento", no qual questiona duramente as propostas de intervenções harmonizadas. Nesse texto, estabelece alguns critérios que julga poder dar conta da questão das inserções em áreas urbanas. Para isto estabelece Irês tipos de tecidos urbanos:

1. "zone de rispettare": onde não se pode construir nada: se um edifício ser substituído por um jardim

2. "incontro tra antico e nuovo": locais onde se pode construir e deve se trabalhar com arquitetura moderna que "brilhará pela sua implantação dinâmica, quadridimensional, aberta, em conclusão, antitética ao contexto";

3. "zone libere da vincoli": as zonas da periferia que deveriam ser um estímulo à cidade moderna, sem limitações quanto à preservação.

Explicita ainda sua discordância com os critérios colocados pelos órgãos de preservação italianos para os edifícios de "substituição": "I discorsi sull'esigenza che l'architettura moderna 'si ambienti' nel contesto in cui s'inserice sembrano dettati dal buon senso; ma, come arrive quase sempre, la via del buon senso conduce ala catástrofe".

A questão principal colocada por Zevi é a de que o "ambientamento" acaba por como uma possibilidade de convivência no tecido histórico: 


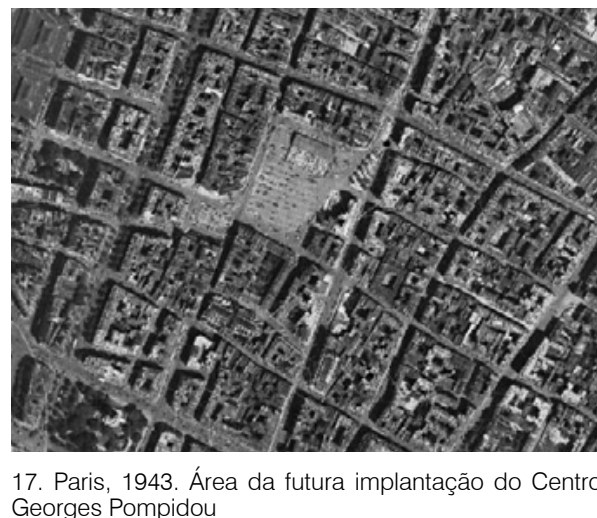

17. Paris, 1943. Áre
Georges Pompidou

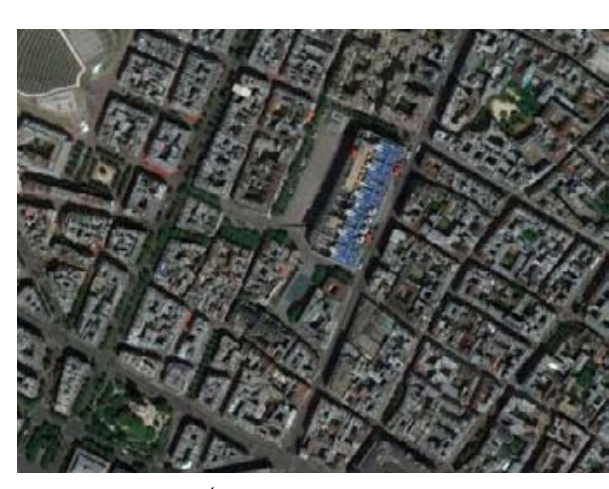

18. Paris, 2016. Área
Georges Pompidou

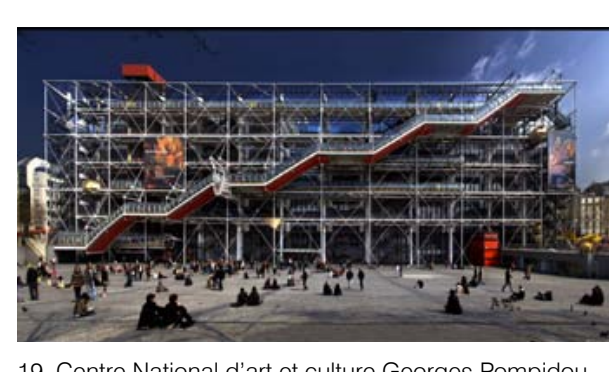

28 Essa questäo terá um desdobramento maior a partir
dos anos 1980 , com a a discussāo do contoxtuation

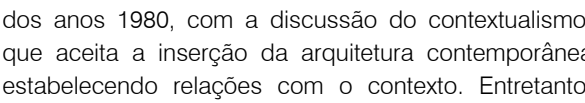
há de se compreander que o moderno que se discutia
nesse momento ainda ara o edificio isolado, que negava

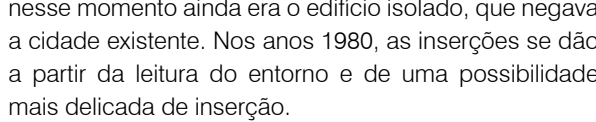

[...] ne nasce questo paradosso: basta fare una brutta architettura per avere il diritto di rovinare il centro storico. Ne discende questa conclusione: per salvare i valori del passato, bisogna lottare per l'architettura moderna, contro le teorie dell'ambientamento che tendono a depravarla e fungono de pretesto per ogni genere di scempi. (ZEVI, 1965)

As "zone de rispettare" evidenciam a dificuldade do tema. Apesar de toda a discussão e da defesa da arquitetura moderna, ele se rende à dificuldade de inserir um edifício moderno em contextos históricos. Para ele, as tentativas, nesse sentido, não se mostraram efetivamente satisfatórias ${ }^{20}$.

Essa discussão inconclusa perde força ao longo dos anos seguintes. A inserção de novos edifícios contemporâneos em tecidos históricos passa a ser uma prática que mais uma vez, entra em outra lógica: a da valorização econômica e urbana

Um dos exemplos mais evidentes é a implantação do Centre National d'art et Culture Georges-Pompidou, em Paris. Vencedor de um concurso internacional, o edifício projetado por Renzo Piano (1937) e Richard Rogers (1933) ocupou uma área pública que estava vazia desde os anos 1940 em decorrência de um conjunto de demoliçōes. Tratase de um edifício de grandes dimensões - 10 níveis de $7.500 \mathrm{~m}^{2}$ cada, absolutamente fora de qualquer padrão ou relação com seu entorno. Abriga um programa cultura bastante intenso: espaços expositivos, o Museu Nacional de Arte Moderna, salas de cinema, sala de espetáculos e de conferências, biblioteca e centro de documentação.

Segundo a própria instituição, o edifício:

[...] présente des caractéristiques techniques qui la rendent unique au monde et en ont fait l'exemple, voire le prototype d'une nouvelle geneneration de museees et de lieux de culture. Son originalité s'affirme principalement à travers la liberation de l'espace des grands plateaux interieurs tout entiers dévolus aux œuvres et aux activites. Leur surface respective de $7.500 \mathrm{~m}^{2}$ est ainsi débarlassée de toutes structures portantes et leur aménagement rendu plus souple et modifiable. Grâce à la structure porteuse rejetée à lexterieur du bâtiment, à lexterionisation des plux, à lutilisation de l'acier (15.000 tonnes) et du verre (11.000 $\mathrm{m}^{2}$ de surface vitrée), les constructeurs ont impose un baltment pécursour des les années 1970, héritier des grandes architectures de fer de l'âge industriel.
Futuriste à bien des égards, le Centre Pompidou s'inscrit dans le droit fil des utopies architecturales des années 1960, d'Archigram et de Superstudio. Le caractère novateur, voire révolutionnaire $d u$ bâtiment, élève le Centre Pompidou au rang des architectures les plus emblématiques de la fin du 20e siècle.

Arquitetura de vanguarda somada a um programa contemporâneo que se 作 Georges Pompidou, foi essencial para a valorização do seu entorno e, mesmo as vozes discordantes, principalmente do ponto de vista da inserção do edifício no contexto histórico, foram aos poucos silenciando perante o evidente sucesso da açâo.

Toda essa discussão evidencia uma questão que será abordada no próximo capítulo. As obras estudadas ou estão na periferia das cidades ou, quando em áreas mais centrais, são obras isoladas, seja num parque, ou no próprio lote. Isso porque, para a primeira geração dos modernos, a cidade existente não era viável, e para a segunda, os poucos casos de inserção na cidade não se mostraram satisfatórios. Um dos casos mais notáveis e o da Torre Velasca, projeto dos anos 1950 do Studio BBPR ${ }^{30}$ em Milão, que tem como princípio a ideia de uma arquitetura ambientada, que dialogue ante agressiva para a cidade

\section{Moderno como patrimônio}

É neste contexto que o moderno começa a ser reconhecido como patrimônio cultural. Portanto, essa valorização traz consigo todas as questões de turismo de massa e de valorização econômica.

Harvey (1992, p. 91) atenta para o fato de que "[...] as cidades e lugares hoje tomam muito mais cuidado para criar uma imagem positiva e de alta qualidade de si mesmos, e têm procurado uma arquitetura e formas de projeto urbano que atendam a essa necessidade".

Assim, a busca de uma imagem idealizada do moderno contribui para esse processo de valorização. Como colocado por Alois Riegl, dentre os valores atribuídos o patrimônio há o "valor de novidade", ou seja, aquele em que não está evidente o desgaste do tempo, o envelhecimento:

A maior parte dos monumentos respondem, entre outros, a uma expectativa dos sentidos ou do espírito que criações novas

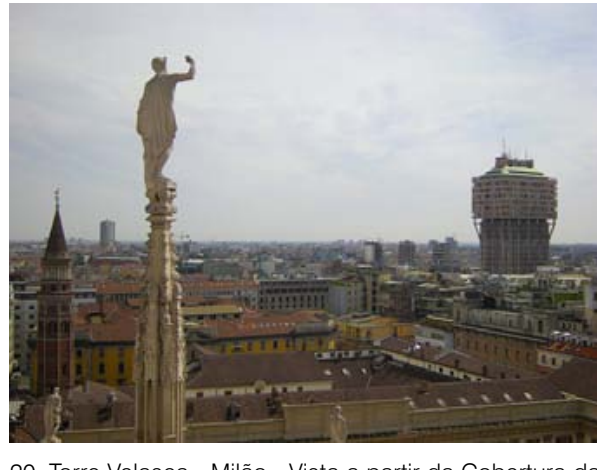

20. Torre Velasca - Miläo - Vista a partir da Cobertura d

\section{Disponivel em: <hitps://mww.centrepompidoutrffrt/
Le-Centre-PompidoulLe-batiment>. Acesso em: 7 nov. 2016.} 30 De Lodovico Barbiano di Belgiojoso (1900-2004).
Enrico Peressutti (1908-1976) e Enesto Nathan Rogers 

nem ao valor de rememoração que dela decorre. Em vez de considerar o monumento como tal, o valor de contemporaneidade tenderá sem dificuldade a nos fazer considerá-lo como igual a uma criação moderna recente, e a também exigir que o monumento (antigo) apresente $\mathrm{o}$ aspecto característico de toda obra human quando primeiro surge: dito de outra forma, que dê a impressãa de uma perfeita integridade, intocada pela ação destruidora da natureza. (KÜHL, 1998, p. 197)

No caso do moderno, essa questão se coloca com maior ênfase, já que as marcas do tempo dão uma aparência de envelhecimento e de má conservação que não condizem com o ideal moderno de atemporalidade, de não envelhecimento.

A preservação do moderno que vem sendo comumente posta em prática é aquela do edifício "novo em folha", como se tivesse acabado de ser construído. A relação e imagética, alinhado com o momento em que esse reconhecimento acontece:

[...] um apego antes às superfícies do que às raízes, à colagem em vez do trabalho em profundidade, a imagens citadas superpostas e não superfícies trabalhadas, a um sentido de tempo e de espaço decaído em lugar do artefato solidamente realizado. E todos esses elementos são aspectos vitais da prática artística na condição pós-moderna. (HARVEY, 1992, p. 63)

Salvo, que estuda a preservação do "novecento" também evidencia o sentido da grande maioria de ações de restauro do moderno:

[...] non è un mistero che la tutela delle opere de Wright sia fonte di un formidabile business che, a sua volta alimenta i ripristini volti a perpetuare l'icona e, insieme, ad adattare e trasformare l'edificio per necessità pratiche, economiche o turistiche: le migliaia di turisti che ogni anno visitano questi monumenti chiedono infatti di trovarli in una condizione di assoluta integrità che renda esplicito, semplice e "consumabile" il loro significato simbolico. (SALVO, 2016, p. 69)
Harvey (1992, p. 70) ainda aponta que "[...] a procura de meios de comunicar distinçães sociais através da aquisição de todo tipo de símbolos de status há muito é uma faceta central da vida urbana"31 e que o valor que uma sociedade atribu a determinados objetos ou rituais pode não ser objetivamente contabilizado. No entanto, esses elementos são simbolicamente valorizados em um primeiro momento e, posteriormente, adquirem um relevante valor econômico. Nesse sentido, cabe a utilização do patrimônio cultural também como capital. Isso ajuda a "[...] compreender o atual fascínio pelo embelezamento, pela ornamentação e pela decoração como códigos e símbolos de distinção social" (HARVEY, 1992, p. 83).

Não se trata de negar a necessidade de reconhecimento da produção moderna como patrimônio cultural, mesmo porque essa já é uma questão consagrada - pelo menos no campo da discussáo sobre preservaçá - mas de compreender as diversas questões que contribuem para esse processo.

Se as primeiras ações de reconhecimento do moderno foram pautadas pela historiografia da arquitetura moderna em diversas obras e publicações - algo que será discutido posteriormente - atualmente a indústria do turismo e o mercado editorial, de moda, audiovisual de eventos têm forte influência nesse reconhecimento. De acordo com Harvey (1992, p. 65) "[ ...] o capitalismo, pra manter seus mercados, se viu forcado a produzir desejos e, portanto, estimular sensibilidades individuais para criar uma nova estética que superasse e se opusesse às formas tradicionais de alta cultura".

Além do aumento significativo de publicações voltadas para o público de arquitetura, há hoje no mercado uma quantidade bastante significativa de publicações que divulgam a arquitetura como produto a ser consumid ${ }^{32}$, e o patrimônio cultural, principalmente quando se trata de conjuntos urbanos ou de intervençôes em edifícios existentes, tem ganhado cada vez mais espaço nessas publicações.

O patrimônio cultural como produto pode ser uma solução para viabilizar ações de preservação Cabe compreender de que forma esses processos estão de fato imbuídos de um sentido de preservacão Para o moderno, parece difícil até o presente momento, tratar do assunto com clareza e distanciamento Essa é a questão que será abordada no próximo capítulo, levantando pontos de difícil abordagem, já que mesmo quando se trata de patrimônio a pouca distância temporal em relação à construção dessas obras tem reflexos diretos no processo de preservação, principalmente no que diz respeito à autoria dos projetos.

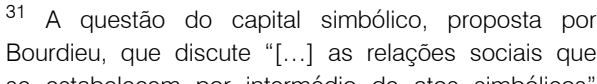

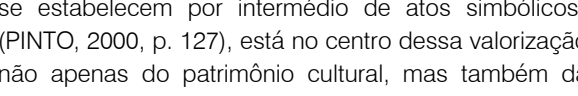
D. arquitetura uma imensa quantidade de livros com

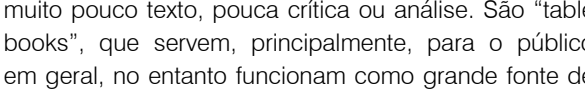
em geral, no entanto funciona
divulgagáa de arcuitetura. 
A preservação da arquitetura moderna tem ganhado espaço cada vez maior no campo do patrimônio cultural. Apesar de se tratar de um assunto relativamente recente, já há uma quantidade considerável de discussões e, principalmente, de intervenções que permitem analisá-lo criticamente.

Neste capítulo, será discutido especificamente o tema da arquitetura moderna como patrimônio cultural a partir de questões que dizem respeito à autoria dos procomo patrimonio cultural a partir de questōes que dizem respeito a autoria dos proto do moderno como patrimônio até as açoōes de preservação, conforme Carvalho (2006, p. 14) exemplifica:

[...] as rápidas mudanças a que está sujeita a sociedade atual comprometem uma avaliação serena deste período, porque fazem com que os papéis de produtores, usuários, críticos e historiadores se sobreponham no tempo. Arquitetos como Le Corbusier, Frank Lloyd Wright e Lúcio Costa se envolvem pessoalmente na batalha para preservar suas obras, dando lugar a uma relação muito diferente com a preexistência e com os bens culturais que merecem ser preservados para as gerações futuras.

Os tópicos colocados, portanto, partem do princípio de que a preservação do moderno não demanda diretrizes específicas, distintas das estabelecidas para a preservação do patrimônio cultural. Pelo contrário, as cartas e documentos de preservação, principalmente a Carta de Veneza, de 1964, que teve como base os princípios do restauro-crítico, são suficientemente abrangentes e flexíveis para atender, inclusive, a esse patrimônio recente O princípio basilar do restauro-crítico estabelece que, para cada estudo realizado sobre um bem cultural, é essencial seu conhecimento da forma mais aprofundada possível'. Exige trabalho multidisciplinar que evidencie as instâncias históricas e artísticas do bem², associado à análise de sua materialidade transformada pelo tempo: 

vés de dialética, em que as oposiçōes se resolvem numa síntese mas de modo algum as instâncias possuem autonomia absoluta não são destacáveis, são faces de um mesmo bem multifacetado são aspectos coexistentes e paritários. (KÜHL, 2009, p. 84)

Segundo a Carta de Veneza, no Artigo $1^{0}$ :

[...] a noção de monumento histórico compreende a criação arquitetônica isolada, bem como o sítio urbano ou rural que dá testemunho de uma civilização particular, de uma evolução significativa ou de um acontecimento histórico. Entende-se não só as grandes criações, mas também as obras modestas, que tenham adquirido, com o tempo, uma significação cultural (CURY, 2000, p. 90)

Uma leitura atenta do artigo apresenta uma das questões mais importantes sobre o patrimônio cultural no século XX: a partir do reconhecimento da obra de arte e de seus valores, não há hierarquia possível entre os bens. Não há bem maior e bem menor Nesse sentido, também não se pode atribuir mais ou menos valor. Cada bem tem seus próprios valores reconhecidos. Edifícios de todos os momentos históricos devem ser considerados de forma igual, independentemente de sua historicidade ou de questões de estilo. Alois Riegl já havia, no início do século XX, questionado a ideia do processo de evolução das artes, estabelecendo que cada movimento artístico tinha o seu valor e isso não o colocava como "menor" com relação a seu sucessor. O que se verifica no caso do moderno é uma constante tentativa de enquadramento em uma "categoria à parte", e que por isso teria questões específicas. Essa abordagem está ligada a questões afetivas, principalmente pela proximidade temporal que separa o moderno de seu reconhecimento como bem cultural e pelo valor icônico que muitos arquitetos e suas respectivas obras assumiram a partir de uma construção historiográfica engajada.

Apesar de soar óbvia, a diretriz que estabelece a necessidade de estudo aprofundado e de reconhecimento dos valores "caso a caso" dos bens culturais tem levado à interpretação equivocada de liberdade absoluta para intervir. No entanto, a grande di ficuldade, apos o reconhecimento dos valores atribuidos aos objetos, e saber relacionáIsso não elimina a criatividade no desenvolvimento do projeto, mas estabelece parâ- metros para as propostas. Assim, não é possivel estabelecer regras universais para as intervençoes. Cada caso exige a mobilização de elementos distintos em função de suas particularidades. Há de se compreender, inclusive, de que forma os valores atribuídos repercutem na sociedade em que os bens estão inseridos. Portanto, os instrumentos se mostram flexíveis para cada caso e para cada cultura, podendo ser aplicados ainda nos dias atuais

Os estudos sobre o tema não são de ordem unicamente histórica:

[...] per "monografia" si deve qui intendere non soltanto una raccolta di dati sulla committenza, l'incarico, le maestranze e il cantiere, sull inquadramento storico usuale, insieme al dossier dei piani di nilievo, della descrizione locale per locale eccetera, ma pure - e aggiungerei, sopratutto - un' analisi architettonica che tragga partito da tutte le risorse, trascorse e attuali, della critica architettonica. II che vuol dire rivisitare e rielaborare criticamente lo (REICHLIN, 2011, p. 16)

Nesse sentido, Bruno Reichlin (2011, p.13) ainda associa o reconhecimento do bem ao desenvolvimento de projetos:

Tutti noi conosciamo casi di opere riconosciute a posteriori come insostituibili e passate invece nel conto delle perdite per non aver incontrato a tempo "la storia" e il loro interprete e mentore. Costruire l'autocoscienza - epistemica ed ermeneutica - capace di pensare, insieme, sia l'oggetto che ci sta di fronte, sia gli strumenti storico-critici per andare incontro a quest' oggetto, è già progetto.

Essa aproximação de pesquisa e projeto diz respeito às questões de preservação de patrimônio de forma geral, mas levanta uma importante discussão em relação ao moderno: a necessidade do desenvolvimento de projetos contemporâneos para preservação desses bens. Segundo Reichlin (2011, p. 23), è a partir da pesquisa que se poderá ter a liberdade de propor intervenções qualificadas nos bens culturais: "Maggiore autocoscienza e proporre nuove percezioni, nuove letture dell'esistente: ecco un bel programma per una salvaguardia che si pretende creativa

Este ainda é um tema que não está bem resolvido e que entra em conflito com uma das posturas mais comuns na preservação do moderno: intervençōes de
Essa abordagem cuida das culturas europeias e, de extrema

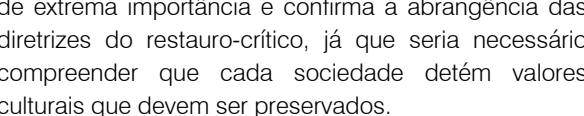



repristinação que almejam uma imagem idealizada e consagrada pela historiografia
moderna. Assim, evitam-se intervençooses e projetos que interfiram na imagem simbólica da obra - uma postura que evidencia a dificuldade de se lidar com esse legado.

Segundo Cabonara (1997, p. 274):

[...] la pulsione è sempre quella di tornare a possedere compiutamente l'opera, di farla propria con una ricreazione totale (si pensi a tuta la vicenda del restauro stilistico); essa è ancora più forte pel'architetto (rispetto, ad esempio, all'archeologo 0 allo storico dell'arte) orientato, per sua natura e formazione, piè al rinnovamentoeal'invenzionecheallaconservazione del'esistente.

Contrariamente às questões levantadas por Reichlin, é crescente a separação entre arquitetura e restauro ${ }^{4}$ como campos diferentes, ao invés de complementares. $\mathrm{H}$ uma clara cisão entre as pesquisas documentais e o desenvolvimento de projetos: os estudos realizados, muitas vezes, são abandonados nas propostas como se não fossem fontes fundamentais de informações. O resultado pretendido nas pesquisas documentais passa a ser uma sistematização e catalogação de informações (história, projetos, desenhos, croquis, imagens, publicações etc.), e não contribuem necessariamente para os processos de conservação e preservação.

É necessário considerar também que algumas abordagens sobre patrimônio cultural, principalmente as adotadas a partir do final do século XVIII e ao longo do século XIX, já não são mais aceitas, do ponto de vista teórico, no campo disciplinar do restauro como hipótese de trabalho. O conhecimento do projeto, da obra e das camadas históricas que se sobrepõem é essencial para direcionar qualquer accão de conservação restauro. Isso, no entanto, não abre a possibilidade para uma recuperação das propostas de Viollet-le-Duc (2000) de "[...] colocar-se no lugar do arquiteto primitivo e suporque ele faria se voltando ao mundo, fossem a ele colocados os programas que nos são propostos" Se havia consenso de que esses postulados já estavam superados, quando se trata do moderno há uma forte tendência a se aproximar das proposições de Viollet-le-Duc. Mesmo nos casos em que existe a possibilidade de consulta aos arquitetos-autores dos projetos e à documentação que contém informações sobre as obras, essa é uma questão que deve ser tratada com atencão redobrada. Exigir um olhar crítico, do ponto de vista da preservação do patrimônio cultural para o próprio autor da obra, do ser uma demanda difícil de ser atendida. Impõe-se um distanciamento para se alcançar uma abordagem desvinculada de todo o processo de concepcão do projeto e de construção do objeto. Compreender todos os valores que a sociedade atribuiu a uma obra e que, por vezes, cão diferentes dos que foram concebidos pelo autor leva a sitaços contradíŕíz. Por isso, o Artigo 11 da Carta de Veneza delimita a aça dos autores das obras: "[...] o julgamento do valor dos elementos em causa e a decisão quanto ao que

Entretanto, além de recorrer aos arquitetos-autores, o que se observa é a consante consulta aos autodenominados herdeiros culturais ou até mesmo aos herdeiros biológicos dos arquitetos-autores, como se fossem os únicos capazes de compreender a obra executada. A questão que se coloca nesses casos é ainda mais complexa. Tratase da necessidade de "[...] um verdadeiro trabalho psíquico de perda, chamado por Freud 'trabalho do luto' - tarefa lenta e dolorosa atraves da qual o eu não só renuncia ao objeto, dele se dis objeto [...]" (RIVERA, 2012, grifos da autora) ${ }^{5}$, e de um efetivo distanciamento - que tem se mostrado muito difíci.

Como já colocado, a obra deve ser entendida após estudos aprofundados realizados por equipes multidisciplinares que compreendam seus diversos valores, a partir das distintas abordagens, para a sociedade nos dias atuais, e não pela suposta autoridade de uma transmissão hereditária, altamente questionável. Supor que esses sucessores são os únicos que podem se posicionar em relação a essas obras tem levado a equívocos enormes. Não por incompetência mas por um vínculo afetivo que dificulta o distanciamento crítico e uma leitura isenta. Não se trata de buscar uma leitura técnica, livre de valores inclusive emocionais, pois qualquer atribuicão de valor tem uma dose considerável de subjetividade que deve ser controlada a partir de um método rigoroso para que não se torne arbitrária. No entanto a interpretação das obras feitas por pessoas próximas aos autores pode vir carregada de fatores externos ao objeto. Por um lado fica evidente, nesses sucessores, uma proposta de "entender o que o arquiteto-autor aria se estivese vivo", por outro, uma maneira de abter os bônus da assinatura- de um projeto, conforme discutido no capítulo anterior.

Em alguns casos, trata-se de herdar o capital simbólico da obra do autor por completo, como se fosse possivel se colocar na posição do arquiteto em todas as situações. Uma das formas de operar e a manutençâo do escritorio com o nome do arquiteto, o que supoe uma conthuidade bastante questionável, já que sugere sua presença e capacidade técnica, fato que é evidentemente inatingível.

É o caso do escritório de Oscar Niemeyer, que até hoje mantém seu nome e . tes do sécul XX por meio de uma herança familiar. A matéria a seguir publicada no site ArchDaily, demonstra essa situação:

Por decisão judicial, a viúva de Oscar Niemeyer, Vera Lúcia Niemeyer, deirou 0 comando do escitório que leva o nome do 
arquiteto, localizado em uma cobertura na Avenida Atlântida, no Rio de Janeiro. A partir de agora, quem assume a direção dos projetos é uma das netas de Niemeyer, Ana Elisa Niemeyer $\mathrm{A}$ disputa pelo espólio é grande desde a morte do arquiteto en dezembro de 2012. A divisão do patrimônio material do arquiteto é relativamente simples, porém, a herança intelectual e o poder de conduzir projetos com a "assinatura" de Niemeyer são também muito valiosos e sua divisão vem ocasionando tensão entre os familiares do arquiteto.

Novo projeto do escritório

O Conselho de Planejamento Territorial e Urbano do DF (Conplan) aprovou projeto do anexo duplo do Ministério do Desenvolvimento padrão dos demais anexos dos ministérios, em termos de dimensões, alturas e acabamentos externos, seguindo inclusive 0 que prevê a lei do tombamento de Brasilia. ${ }^{6}$

Outro caso semelhante é o de Rino Levi (1901-1965), que, mesmo após a sua morte, teve por muitos anos o nome vinculado a seu escritório, quando seus antigos parceiros e colaboradores assumiram a responsabilidade dos trabalhos. Manteve assim uma importante carteira de clientes e projetos, pautados ainda no nome do arquiteto já falecido.

\section{Reconhecimento de valor}

Os processos de reconhecimento de valor do moderno têm históricos diferentes, mas todos partem de uma mesma lógica evidente: a valorização dos edifícios "canônicos" em consonância com o estabelecido a partir da historiografia consagrada do modernismo, que considera não apenas o edifício, mas também a relevância de seus

A historiografia da primeira geração dos modernos se confunde com a realização dos CIAM, que determinava princípios e diretrizes para a arquitetura moderna Temas como habitação social e cidade funcional permearam os primeiros congressos, estabelecendo os principais campos de discussão dos grupos que os coordenavam. dello storico-ricercatore, dello scopo stesso della ricerca, della
temperie culturale nella quale si svolge. La conoscenza che si ha del passato è sempre limitata; ne consegue che l'operatività di restauro non può né deve nascere e svilupparsi dalla storiografia. (CARBONARA, 1997, p. 359)

Segundo Ana Barone (2002, p. 25), que estudou pormenorizadamente os CIAM,

[...] outro importante fator que levou à consolidação da hegemonia foi a centralização da gestão interna dos congressos em um comitê formado por Walter Gropius, Le Corbusier, Sigfried Giedion, Jose Luis Sert e Cornelius van Eesteren. Eles determinavam o rumo das discussões, fazendo enfraquecerem outros grupos que levantassem temas incompatíveis com seus interesses práticos. Finalmente, a historiografia também teve papel importante na consolidação da hegemonia do Movimento Moderno em Arquitetura a partir dos CIAM, muitas vezes identificando os congressos com o próprio movimento.

Segundo Simona Salvo (2016, p. 126):

[...] ne sono emersi, per esempio, a margine delle recenti proposte di sottoporre a tutela l'intero corpus delle opere di Le Corbusier e di Frank Lloyd Wright, dichiarandole "in blocco" Patrimonio dell' 'umanità, ma ancora con scarsi risultati e senza garanzia di un'effettiva conservazione. [...] In ogni caso, questo tipo d'iniziative evidenzia la tendenza a promuovere più che altro il culto di questi grandi architetti, che lascia prevalere la dimensione internazionale che le loro opere hanno assunto nel corso del Novecento.

caso do reconhecimento do moderno como patrimônio cultural tem uma história peculiar no Brasili. O SPHAN (Serviço do Patrimônio Artistico e Histórico Nacional), primeiro órgão público federal de preservação do patrimônio cultural, foi criado em 1936 e implementado em 1937. Desde então, foi dirigido por um grupo de arquitetos ligado à produção da arquitetura moderna. Com a missão de construir uma identidade cultural nacional, o grupo liderado por Lúcio Costa (1902-1998) e Rodrigo de Melo Franco 

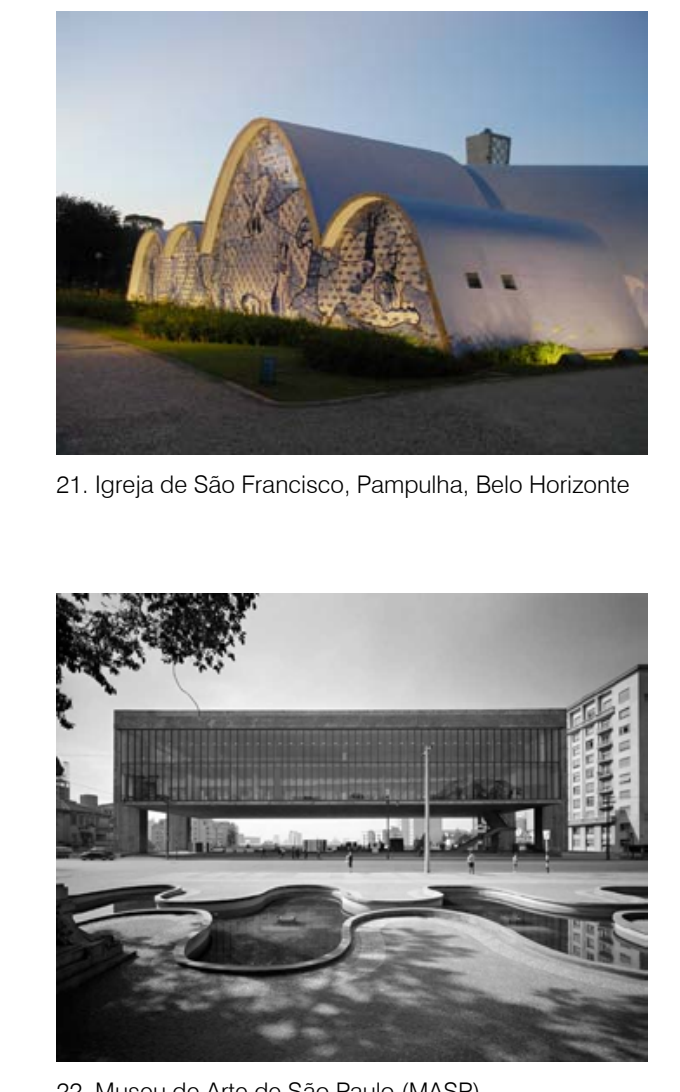

22. Museu de Arte de Săo Paulo (MASP)

CHUVA (2003).

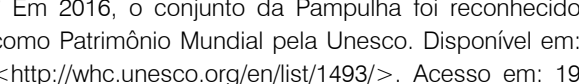
dez. 2016 .

9 Para saber sobre a atuagăa do CONDEPHAAT ver
WOLFF (1998)

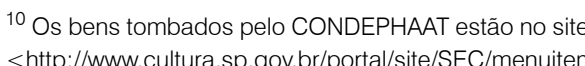

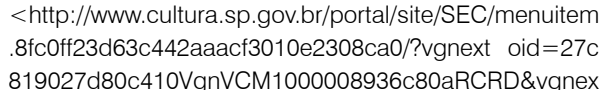

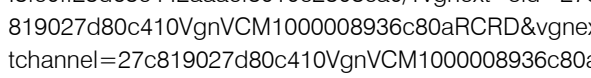

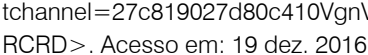

(1898-1969) tombou obras modernas, algumas recém-construídas. A intenção era de fazendo una referência à arquitetura produzida nos seculos XVII e XVIII, mostrar uma relação direta com a produçăo moderna do século XX, excluindo qualquer manifestação eclética do século XIX e início do XX

O caso da Igreja de São Francisco, em Belo Horizonte, projeto de Oscar Niemeyer, reflete essa postura do órgão que, com o forte posicionamento de Lúcio Costa, cria o "tombamento preventivo"

Considerando, enfim, que o valor excepcional desse monumento o destina a ser inscrito, mais cedo ou mais tarde, nos Livros do Tombo, como monumento Nacional, e que portanto seria criminoso vê-lo arruinar-se por falta de medidas oportunas de preservaçăo, para se haver de intervir mais tarde no sentido de uma restauraçáa dilioll o onerosa, ton ho a honra de propor de acordo com os itens I e lil do Art. 90 do Decreto Lei $n^{\circ} 25$, de 30 de novembro de 1937, O tombamento proventivo da lgreja de São Francisco de Assis, da Pampulha [...] (COSTA, 1999, p. 68)

Os órgãos de preservação estaduais iniciam os processos de tombamento no final dos anos 1970 e seguem a lógica de se amparar na historiografia consagrada, protegendo, de inicio, os edificicios canônicos de cada local ${ }^{9}$. No CONDEPHAAT, o primeiro edirio modemo lombado foi a FAU, a Faculdade de Arquiletura e Uibanismo da USP, projeto de Vilanova Artigas (1915-1985), e em seguida o MASP (Museu de Arte de São Paulo Assis Chateaubrand), projeto de Lina Bo Bardi (1914-1992), ambos em 1082 S. No Rio de Janeiro, o INEPAC (Instituto Estadual de Patrimônio Cultural) tomba, em 1978, o Edifício da Obra do Berço, de Oscar Niemeyer, e o Teatro Armando Gonzaga, de Affonso Eduardo Reidy (1909-1964).

A postura de reconhecimento diretamente vinculada à historiografia se mostrou insuficiente para a preservação da extensa produção do século XX que definitivamente, não se restringia a essas obras canônicas. O que se observa, a partir dos anos 1980, é uma revisão historiográfica do moderno, que vai reconhecer uma produção plural com variações ao redor do mundo, e que também merece ser reconhecida.

Soma-se a isso a

[...] continua ampliação, que se acentuou nas últimas décadas, daquilo que é considerado bem de interesse cuttural a ser preservado, estendendo-se a um número cada vez maior a tipos cada vez mais variados e a um passado cada vez mais próximo. A preservação volta-se, assim, não mais apenas às obras de excepcional importância histórica e qualidade artistica, como ocorrera no século XIX, mas também a todos os bens que - como enfatizado na Carta de Veneza, documento base do ICOMOS (International Council on Monuments and Sites) órgão da Unesco, de 1964 com o tempo adquiriram significação cultural' ou seja a todos os bens que são testemunhos significativos da operosidade humana e que são suportes da memória coletiva. (KÜHL, 2006, p. 19)

Os casos a seguir ilustram como os arquitetos-autores interferiram nos processos de reconhecimento de valor de suas próprias obras.

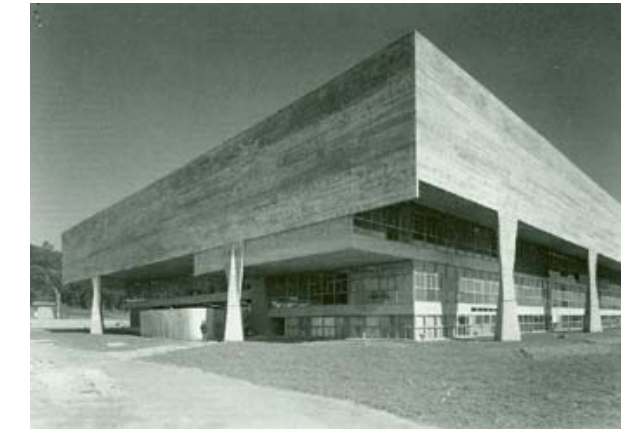

\section{Faculdaded de Arquitetura e Urbanismo
Universididade de Sáo Paulo (FAU-USP)}
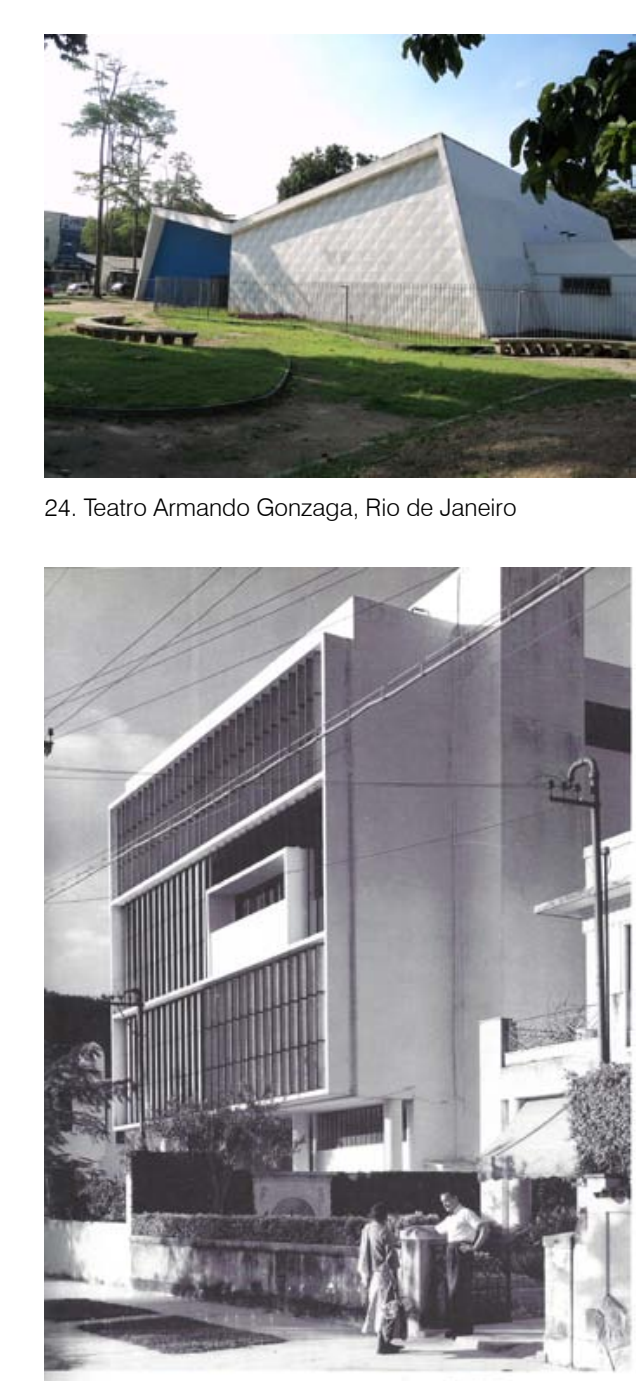

25. Obra do Berço, Rio de Janeiro 


\section{Tombamento das obras de Oscar Niemeyer}

A relação entre a preservação de obras e o posicionamento de seus autores é sempre controversa. No caso de Oscar Niemeyer, o IPHAN ${ }^{12}$ inicia, em 2007, um processo ${ }^{13}$ de tombamento de suas obras. Como colocado anteriormente, algumas delas já haviam sido protegidas, mas, no ano do centenário do arquiteto, esse reconhecimento também seria uma homenagem. O processo teve início com uma carta enviada por Niemeyer ao então Ministro da Cultura, Juca Ferreira, na qual lista os edifícios que, segundo ele, deveriam ser tombados ${ }^{14}$

A lista é acolhida pelo IPHAN, que inicia o processo com a análise das obras selecionadas. Em um primeiro momento são escolhidas as obras de Brasília e a Casa das Canoas, no Rio de Janeiro (RJ), por sugestão da arquiteta Maria Regina Weissheimer, do DEPAM (Departamento de Patrimônio Material e Fiscalização, do IPHAN) (IPHAN, 2007 v. 1, p. 36). O processo, dentro do órgão, permite a inclusão de outras obras, como fo o caso do Parque Ibirapuera - que será discutido no próximo capítulo.

A análise desses processos ratifica a ideia da mitificação do arquiteto. A reunião do Conselho Consultivo do Patrimônio Cultural do IPHAN, realizada no dia 6 de dezembro de 2007, decide pela abertura do processo de tombamento, a partir do relatório do conselheiro Nestor Reis Goulart Filho (IPHAN, 2007, v. 2, p. 238). Nesse documento Goulart Filho concorda com a abertura do processo de tombamento dos imóveis indicados pela superintendência de Brasília (23 imóveis em Brasília) e da Casa das Canoas. A lista de Niemeyer não é plenamente atendida mas serve como base para as indicações.

Há ainda uma extensa discussão sobre a inclusão de obras a serem tombadas e vale notar como a discussão sempre mistura a biografia do autor, seus familiares e amigos, e as obras propriamente ditas. Goulart Filho, logo no início de seu parecer, já coloca:

Trata-se de uma incumbência extremamente honrosa e um prazer especial para este Conselheiro formado intelectualmente com zer especial para este Conselheiro, formado intelectualmente com tão presentes neste Conselho ilustres colegas, amigos pessoais e antigos colaboradores do arquiteto Oscar Niemeyer na construcão de Brasilia que certamente estariam mais qualificados para exame do assunto. (IPHAN, 2007, v. 2, p. 231)

Quando discorre sobre as obras a serem tombadas e a definição dos critérios e

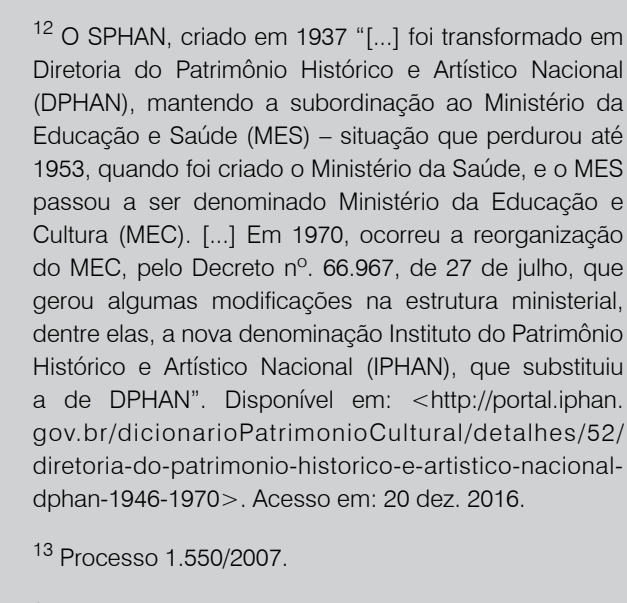

Além de ter se iniciado de forma questionável, repete o procedimento de Lúcio Costa nos primórdios
do IPHAN, pedindo o tombamento, inclusive, de obras
ainda nâo concluídas. 
que é amigo de Oscar Niemeyer, trabalhou com ele, para verificarmos a fundamentação de cada caso, o que estava claro e o que não estava claro" (IPHAN, 2007, v 2 p. 232).

Na sessão em que foi votado o tombamento do conjunto de obras, o conselheiro Paulo Ormindo de Oliveira propôs:

Gostaria de chamar a atenção para aspectos formais de tombamento. Penso que deve haver a enumeração de todos os objetos incluidos no tombamento, mais do que isso, uma serie de elementos informativos. Compreendo tambem que há uma circunstância - a idade do arquiteto - que dificulta, agora, implementar toda essa informação. Assim, a minha proposta è que se fizesse uma declaraçáo de tombamento da obra completa, o conjunto da obra de Oscar Niemeyer, e num segundo momento, se providenclasse toda a documentaçáo. Nesse momento fariamos, como algumas academias fazem, o conjunto da obra de um autor, ou de um alor, ou de um diretor, no caso do onema, e depois seria fella a instruçáa de um processo para cada uma delas, devidamente detahadas. Porque, realmente, o tombamento fica muito incompleto. Por exemplo, mesmo algumas de Brasila năo estâa no corpo do parecer, pelo que entendi. Numa visão da obra de Oscar Niemeyer, por exemplo, há unia serie de obras primeiras que não podem ser somente a culminaça de Braslilia. Acho que ate para compreender a obra de Oscar Niemeyer, ha uma serie de obras pequenas, como foi citada a sua primeira casa, e não a das Canoas, e uma sene de oulras obras esparsas en todo o pals. Agora, em lugar de tombar uma parte e depois outra, considero muito mais interessante tombar o conjunto da obra e depois fazer a instruçaa desses pross com o inventário de todas as obras. (IPHAN, 2007,v. 2 p. 295)

E o conselheiro Ulpiano Bezerra de Menezes ponderou:

Acho um pouco perigoso tombamento de obra geral. Isso cria uma série de problemas. Em primeiro lugar, do ponto de vista puramente juridico é complicado na medica en que o tombamento fazer e não fazer, portanto os objetos, a respeito dos quais as obrigaçōes de fazer e não fazer são compulsórias, devem ser explicitamente definidos. Então é complicado, sem contar também que o tombamento implica uma seleção, qualquer que ela seja, e a mera autoria não me parece que seja suficiente como seleção. (IPHAN, 2007,v. 2, p. 297)

Ao final dessa sessão ficaram tombadas: o Palácio da Alvorada (conjunto arquitetônico, incluindo a Capela); a Capela Nossa Senhora de Fátima; a Praça dos Três Poderes; o Congresso Nacional; o Museu da Cidade; o Palácio do Planalto; o Supremo Tribunal Federal; a Casa de Chá; o Pombal; o Espaço Lúcio Costa; os Ministérios e anexos; O Palácio da Justiça; o Palácio ltamaraty e anexos; O Panteão da Liberdade e Democracia; o Teatro Nacional; o Quartel General do Exército; o Palácio Jaburu; o Memoria

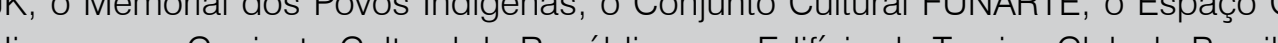
Niemeyer; o Conjunto Cultural da República; e o Edifício do Touring Club do Brasi.

Parecer 002-2016 assinado por Andrey Rosenthal Schlee, diretor do DEPAM PHAN, faz uma síntese de todo o processo, uma breve retrospectiva da produção de Niemeyer e estabelece uma periodização. Além das obras já tombadas pelo Conselho na reunião de 2007, decide pelo tombamento das seguintes obras: o Museu de Arte Contemporânea de Niterói (RJ): 0 coniunto de edificações projetadas para o Parque birapuera (esse tema será retomado no próximo capítulo), em São Paulo (SP); e a Passarela do Samba, no Rio de Janeiro (RJ): e pela abertura do processo de tombamento do Edifício Copan, em São Paulo; dos Pavilhões de Serviços Gerais da Universidade de Brasília (DF); e do Museu Oscar Niemeyer, em Curitiba (PR).

o processo ainda vai ser finalizado e não se trata de discutir a sua validade. Pelo contrário, efetivamente há um grande número de obras de Niemeyer a preservar Nesse sentido, o IPHAN teve uma postura tecnica, anallsando o valor a ser preservado e não caindo na armadiliha do tombamento do conjunto integral da obra. A questão principal que se coloca é que a participação de Niemeyer neste caso foi com o objetivo de preservação, mas, como será discutido adiante, em diversos outros casos, seu posicionamento contrário à conservaçăo de suas obras também foi essencial e acarretou em perdas (Duchen, ver página 83) ou em intervenções bastante problemáticas (Parque birapuera, ver capítulo 3). 


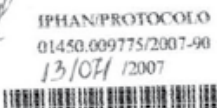

Prezado Ministro,

De acordo com a conversa que tivemos dias atrás em meu escritiónio edificios por mim projetados. ficou acertado que the enviaria uma relą̧o desses prèdios (ver anexo).

Alguns, como os que integram o Caminho Niemeyer em Niterói, reclamam essa medida com maior urgência - inclusive o Teatro Popular, cujas obr ș

A sua intervenção nessa matéria me deu uma nova esperança. Afinal, por agradecimentos sinceros que lhe dirijo.

Cordialmente,

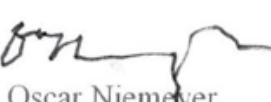

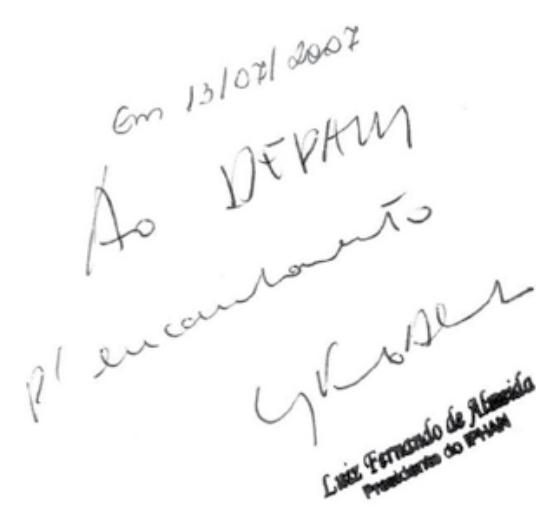

no
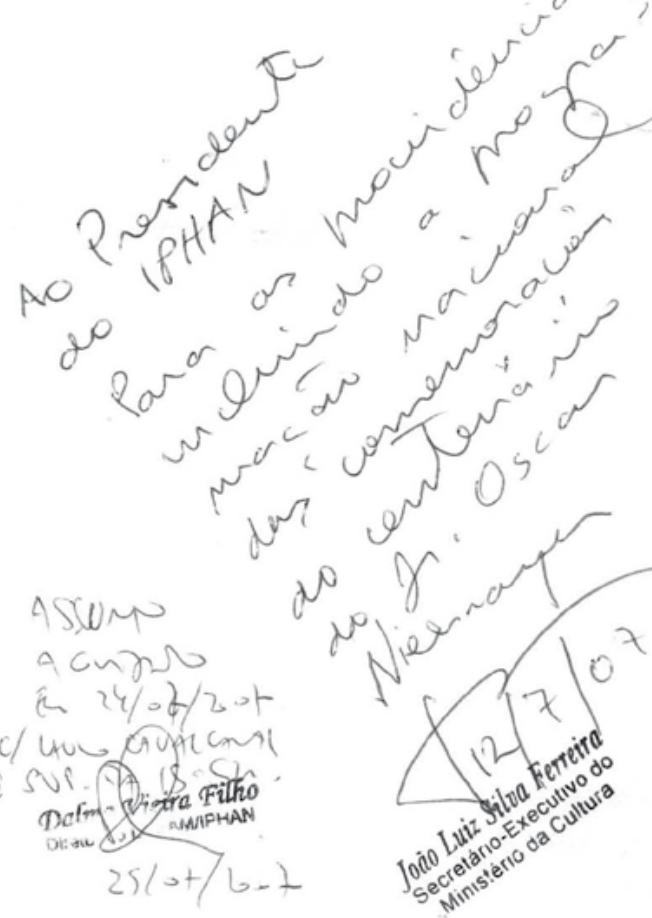

ANEXO

$\frac{\text { Rio de Janeiro }}{- \text { Casa das }}$

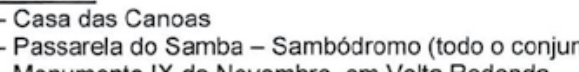
Museu de Arte Contemporânea de Niterói

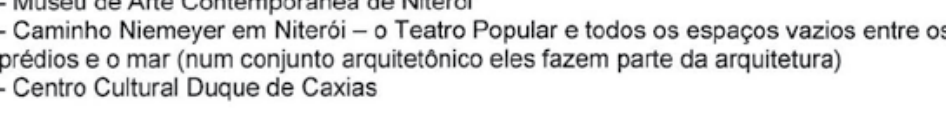

Săo Paulo

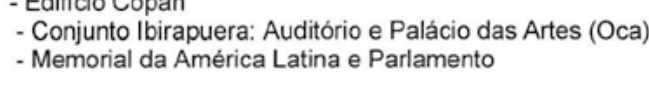

Minas Gerais
-Coniunto da Pampulha: Igreja de Săo Francisco de Assis, Cassino, Casa do Baile

Brasilia. Pa

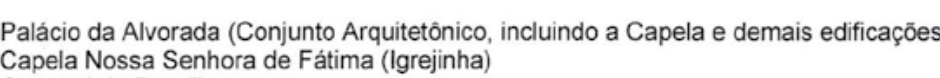

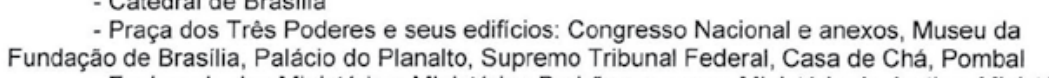

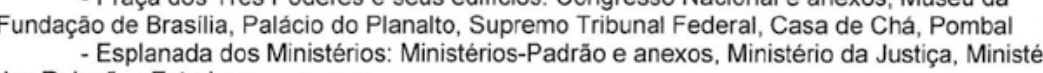

das Relaçôes Exteriores e anexos - Tanteán da cliberdade e da Democracia Tancredo Neves
- Teatro Nacional
- Quartel-General do Exéritio

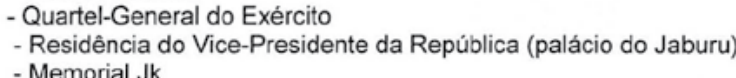
- Museu do Indio

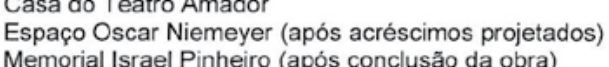
Parane

Goiás - Centro Cutural Oscar Niemeyer Rio Grande do Norte
- Torre no Parque de Natal

$$
\begin{aligned}
& \operatorname{Lin} 16107 \\
& \frac{\text { Silevona }}{\text { DER }} 16^{07} \\
& \text { on }
\end{aligned}
$$




\section{Arquitetura e outras artes}

A relação conceitual com outras artes é bastante utilizada para amparar algumas ações de preservação. São comparações que eliminam as diferenças entre os campos, justamente as que estabelecem as distinções primordiais.

É comum a construção de uma analogia entre a partitura musical e o projeto de arquitetura. Ambos seriam, supostamente, a representação fiel da obra final. Com base em uma partitura seria possivel executar infinitamente a mesma música, como foi pensada pelo seu autor. Mas al há um problema serrio. Não por acaso, os músicos são chamados de interpretes. Se a partitura fosse algo rigoroso, sem diretito a leituras variadas, teriamos apenas uma interpretação possivel, consagrada e definitiva. Năo haveria nenhuma diferença entre a execução de um ou outro músico. Estariamos fadados a um engessamento da obra. Basta ouvir duas gravaçoes da mesma música para ver que isso náo é verdade. Alé porque as indicaçoes em uma partitura năo são definidas de modo absoluto, ou alguém se arreveria a estabelecer una lei para o planissimo, fortissimo, allegro ma non troppo, entre outros t. E a contagem do tempo? Poderiamos executada. Qual é então a versão original?

A interpretação de grupos como o II Giardino Armonico ${ }^{17}$, que tenta se aproximar ao máximo da sonoridade da música barroca conforme ela foi concebida, com os instrumentos mais próximos aos da época da composição das obras, permite ouvir uma música completamente diferente daquela conhecida até pouco tempo ${ }^{18}$ Uma não invalida a outra. A mesma partitura aceita diversas interpretações, todas elas válidas e originais.

A música se situa no campo das artes performáticas e tem uma relação particular com a materialidade da obra, se comparada com a arquitetura (e outras artes ditas plásticas). A obra de arquitetura, uma vez construída, permanece. Materializa o projeto e consagra uma construção, uma forma e um espaço. Muitas vezes, nesse processo, definiçoes do projeto são alleradas em funçáo de questôes apresentadas no canteir de obras, como colocado anteriormente. Além disso, o fato de perdurar no tempo traz alterações no próprio corpo da obra, que passam a fazer parte de sua existência

O mesmo se dá na comparação da arquitetura com a escultura moldada. O molde da escultura em bronze é concebido para gerar múttiplos sem original. Apesar de algumas pequenas diferenças que podem aparecer entre uma fundição e outra, ninguém ousaria dizer que não sãa originais, ou questionar a sua autoria. Feitas as cópias, não o são pelos motivos já expostos: a relação com o ambiente, as alterações no canteiro, a sobreposição das marcas do tempo que o edifício incorpora etc.
Portanto, a comparação carece, entre outros problemas, de reconhecimento do processo tecnico de produção e da relação das manifestações artísticas com as respectivas materialidades. A arquitetura pode ter os "tipos" 19 , pode ser pensada de forma industrializada e repetida. Nesses casos, poderíamos falar até de réplicas e ausência de originais. Mas é necessário reconhecer que até mesmo essas obras seriadas se transormam, cada qual, de maneira diferente ao longo do tempo (em função do ambiente em que estão inseridas, do modo como são mantidas) e estabelecem relações distintas com seu entorno Se o tema é problemático inclusive para obras industrializadas, estender o conceito de seriação para toda a produção arquitetônica soa, no mínimo, leviano, e esconde os propósitos reais de tais ações.

Por fim, a relação com a tradução - talvez a comparação que mais se aproxima da abordagem da arquitetura e do restauro. Segundo Ortega y Gasset (1883-1955), o bom tradutor e aquele que sabe da impossibilidade de una tradução que gere um texto idêntico ao original.

Traduttore, traditore: a expressão italiana evidencia a dificuldade do trabalho de traducãa. Decisões deverão ser tomadas de acordo com a escolha do tradutor: a métrica, o jogo de palavras, a rima Cabe, portanto, avaliar quais serão os critérios preponderantes para que a tradução alcance o seu leitor Outros valores reconhecidos, eventualmente, terão menor destaque. Da mesma forma, quando se reconhece um bem cultural, diversos valores lhe serão atribuídos, tais como as instâncias histórica e estética que por vezes se sobrepõem uma à outra, e as demandas da sociedade, que vêm ganhando cada vez mais espaço nas discussões sobre cidade e arquitetura Cabe àqueles que vão tratar do tema - uma equipe multidisciplinar, devidamente versada nessas questões - estabelecer os valores que serão preservados. Eventualmente, em detrimento de ou-

A diferença substancial entre os dois campos é que, na tradução, os documentos originais continuam disponíveis para verificação, novas versões e interpretações. No campo da arquitetura, o trabalho de restauro se dá diretamente sobre a mateilat No do documento original, a obra, e pode resultar em eventuais perdas irrecuperáveis.
17. Página do grupo: : chtpt://mw
com/>. Acesso en: 19 dez: 2016.

18 Para a discussäo desses temas envolvendo lundamentadada em micidás insica e e para uma bibiliogra complementar sobre o tema
FABBAN (2001) e HAYNES (2007)

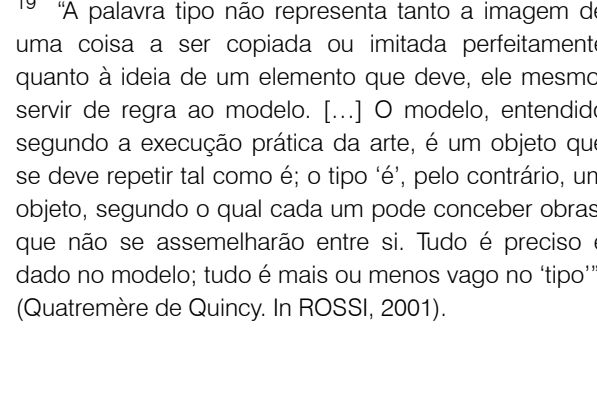

AUTORIA 


\section{Ausência de reconhecimento}

A falta de reconhecimento oficial ainda é uma questão que leva a perdas consideráveis do ponto de vista da preservação do moderno. A ampliação do campo do patrimônio cultural, que inclui edifícios industriais e de habitação, e ainda, o fato de parte para os intensos processos de evolução das manchas urbanas, que trabalham, na sua grande maioria, com a ideia de "tabula rasa" e desconsideram a possibilidade de incor-

Apesar das inúmeras discussões acerca da necessidade da conservação integrada ao planejamento urbano e territorial nos anos $1970^{21}$, as políticas públicas e 0 mercado imobiliario tendem a considerar a preservação como grande entrave para seus novos projelos. Casos recen as mostram a difould da de consenvacho dessas obras positivenente nos planos e projetos urbanos.

Mais do que as legislações de proteção de patrimônio, ou os pesquisadores $e$ órgãos de preservação, são os movimentos sociais, de moradores e usuários desses edifícios, que têm evidenciado seu valor e se posicionado, com eficiência, pela sua preservação ${ }^{22}$

Segundo Reichlin (1997, p. 3),

[...] il y a d'excellentes raisons pour sauvegarder un édifice des années 70-80, qui in'ontrienàvoir avec sa valeur historico-artistique mais qui mettent en avant l'économie des moyens employés pour récuperer des surfaces habitables, le choix écologique de la non-démolition et le respect des uilisateurs des lieux. Ce type de sauvegarde reunit autour du même objectif des acteurs que tout sépare dun point de vue culturel el programmalique. peut êre appliqué à la plus grando partio du parc inmobilier et même préfigurer une gestion territoriale en rupture avec les Trente Glorieuses. Tortanto, de compreender a multiplicidade da produção do século XX que teve diversas correntes, todas com valores específicos a preservar e não se limitar a recontos pode ser obsernos na segunda metade do sécul XXX - a chamada segunda geraçãodessa produção ter ocorrido em áreas periféricas das cidades ${ }^{20}$, acarretaram perdas porar edifícios existentes em seus planos.

princípios estabelecidos até então, incorporando novos temas para discussão e novos para os problemas anteriormente estabelecidos: habitação social e cidade fun-

Apesar de aparentar uma unicidade nas posturas, já nos primeiros CIAM era possível observar divergências no grupo que liderava os congressos. O grupo alemão inha um olhar mais objetivo, baseado em questoees já colocadas em prática em seu pais de origem. O grupo francês tratava de questoes teóricas de concepçöes amplas, congresso o faz chegar ao seu fim, no CIAM $X^{23}$

A partir da década de 1980, inicia-se um processo de revisão historiográfica que inclui outros autores, obras e países, evidenciando as diversas nuances do moderno que ficaram em segundo plano nos primeiros manuais de arquitetura moderna.

Frampton (1997) aponta as distintas variantes do moderno em função de condiçōes "climáticas e culturais". Aponta a relevância da produção de diversos arquitetos fora dos eixos principals trabahnados pela historiografia modena. Cila os casos da Inglaterra, Thecoslovaqquia, Espanha, Africa do Sul, Brasil, Japão entre outros. Mostra como a produção nesses lugares, apesar de ter sua origem na relação com a produção moderna europeia, se descola do Estlo in ternacional para incorporar relaçoes com as (x. elas clińticas, topogaticas ou culluras, anda na pineira metade do século XX

Essa revisão, com a ampliação da produção moderna, acabou sendo essencial para a possibilidade de uma leitura abrangente que permitisse a abordagem como patrimônio, na segunda metade do século XX.

A criação do DOCOMOMO - International committee for documentation and conservation of buildings, sites and neighborhoods of the modern movement -, na Holanda, em $1988^{24}$, e sua implantação em vários locais do mundo vão colocar toda a produção do século XX sob una nova perspectiva: a ideia de que há un patimônio ente do inventário do moderno, que é um passo essencial para a sua preservação.

Consequência direta da pouca distância entre a produção e o reconhecimento é o fato de que diversos edifícios foram tombados enquanto seus autores, ou membros de sua equipe, ainda estavam vivos. A opinião dessas pessoas para a valorização é bastante controversa. Evidentemente, são contribuições valiosas, pois podem trazer informações relevantes. Mas há de se compreender a dificuldade de abordagem das obras, por parte de seus autores, como patrimônio cultural já que não há o distanciaobras, por parte de seus autores, como patrimônio cultural, já que não há o distanciapartir de um olhar que deveria ser externo, conforme colocado anteriormente. Assim, em
${ }^{3}$ Ver BARONE (2002)

"In the last decades, the architectural hertiage of the

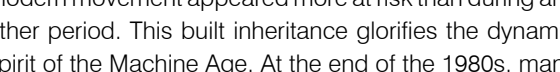

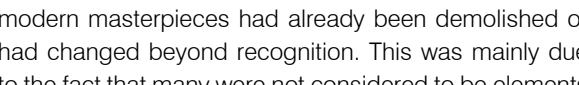
to the fact that many were not considered to be elements of heritage, that their original functions have substantially
changed and that their technological innovations have
not always endured long-term stresses. Docomomo

movemen

-exchange ideas relating to conservation technology
history and education foster interest in the ideas and -elict responsibility towards this recent architectura

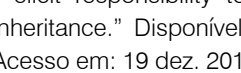


grande parte dos casos, essas obras são tratadas de forma pragmática, de atualização e modernização como se o edifício fosse um trabalho em aberto.

Em tempos recentes, razōes pragmáticas, de cunho setorial e imediatista, muitas vezes disfarçadas de açōes culturais, voltam a prevalecer, mesmo em relação a bens reconhecidos legalmente como partimônio cultural. Imperam razōes que trazem beneficios materiais, esquecendo-se as raízes espirituais que motivam o campo. As ações são ditadas por questões utilitárias: pelo uso pela especulação em busca de maiores lucros, para se obter visibilidade, tambem com intuitos politico-eleitorais (resultante de certas práticas politico-partidárias atuais e não da politica entendida como administraçáo pública vollada ao bem da coletividade). Questões de ordem prática não podem ser desprezadas, são antes, essenciais e devem estar presentes, mas deixam de ser unicas e prevalentes e passam a ser concomitantes, ter caráter indicativo, mas não determinante, se a preservação é de fato um ato de cultura. São empregadas como meios de preservar, mas não como a finalidade, em si, da ação. (KÜHL, 2006, p. 21)

Numerosos edifícios foram alterados ou até demolidos com o aval de seus autores ou de seus herdeiros culturais e biológicos. Essa não é uma questão de fáci solução. Contra uma argumentação de leitura abrangente - que acompanhe as recomendações e diretrizes para a preservação do patrimônio cultural - se opõe o próprio arquiteto com a suposta autoridade de um conhecimento inquestionável. Entretanto, cabe ressaltar que o reconhecimento como patrimônio cultural exige uma abordagem diversa. Não apenas do profundo conhecimento da obra em si, mas dos valores atribuídos pela sociedade. É nesse ponto que a postura dos autores pode se fragilizar.

O olhar fetichista e mitfificado para os principais arquitetos modernos coloca a questáo de forma categórica: quem teria autoridade para contrapor a postura dos "grandes mestres"?

Do ponto de vista da preservação, a resposta é indiscutível: pesquisadores de várias áreas do saber e arquitetos que se dediquem a conhecer todas as camadas de valor que se sobrepõem à obra, levando em conta a visão dos diversos grupos sociais, inclusive as contradições presentes nas obras que, nos casos das icônicas, são invariadescartadas. Essa abordagem deve ser feita no momento de reconhecimento

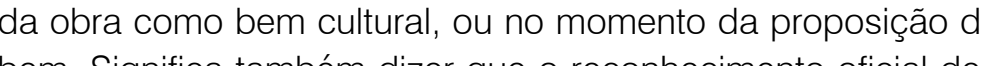
chen determinado momento não congela o edifício no tempo. As ações de restauro são sempre realizadas na construção existente da forma como se encontra, a partir da já discutida leitura crítica. Portanto, não pode ter caráter nostálgico em hipótese alguma - uma postura que é muito comum e que será discutida adiante.

É possível encontrar casos em que a relação do autor com sua obra pode ter acarretado intervenções lesivas ou demolições completas pela impossibilidade de reconhecer em sua própria obra um valor de patrimônio cultural.

Em outros casos, o resultado pode ser satisfatório. Por vias tortas, o arquiteto-autor, na defesa de sua própria obra, preserva o edifício com critérios adequados, mesmo que o tema não seja abordado do ponto de vista do patrimônio cultural. Ou seja, autor e equipe, com o desejo de proteger a produção, estabelecem limites de intervenção que terminam por preservar seu valor cultural.

Os casos estudados a seguir evidenciam diferentes situações nas quais a ausência de reconhecimento pode levar, ou à perdas de edifícios significativos, ou à intervenções de caráter pragmático, que desconsideram eventuais valores culturais. 


\section{Robin Hood Garden - Alison e Peter Smithson}

O conjunto habitacional Robin Hood Garden, de autoria do casal Smithson, finalizado em 1972, está correndo o risco de ser demolido em função do crescimento da implantação de novos edifícios no grande lote do conjunto.

Alison (1928-1993) e Peter Smithson (1923-2003) participaram do último CIAM, que aconteceu em 1959, em Otterlo, na Holanda, e que abriu a possibilidade para que arquitetos mais novos se posicionassem. Durante a organização do congresso Le Corbusier já anuncia que

$$
\begin{aligned}
& \text { [...] são aqueles que têm } 40 \text { anos, nascidos por volta de 1916, en- } \\
& \text { tre guerras e revoluções, e aqueles que têm hoje } 25 \text { anos, nasci- } \\
& \text { dos por volta de 1930, durante a preparação de uma nova guerra } \\
& \text { e em tempos de uma profunda crise econômica, social e política- } \\
& \text { por se encontrarem no centro do presente período - os únicos ca- } \\
& \text { pazes de sentir pessoalmente e profundamente o problema atual, } \\
& \text { os objetivos a perseguir, os meios de consegui-los, a urgência } \\
& \text { patética da atual situação. Eles sabem. Os seus antecessores não } \\
& \text { são mais, estão fora, eles não são mais sujeitos do impacto direto } \\
& \text { da situação. (LE CORBUSIER, } 1959 \text { apud BARONE, 2002, p. 57). }
\end{aligned}
$$

É esse grupo de jovens arquitetos que propõe a extinção do CIAM e que inicia o TEAM 10: "[...] a origem do grupo marca-se pela necessidade de discutir a humanização dos espaços lismo proposto pelo CIAM" (BARONE, 2002, p. 61)

Nesse contexto, os Smithson abordam a discussão sobre a "[...] possibilidade de pensar a cidade a partir dos padrões de associação entre grupos e das relações de identidade[, que] permitiam focalizar as atençōes dos arquitetos para as interfaces existentes entre as diversas escalas" (BARONE, 2002, p. 79), e "Estiveram entre os fundadores do movimento brutalista inglês dos anos [19]50, responsável pela atualização do debate em arquitetura moderna naquele país" (BARONE, 2002, p. 128).

O conjunto habitacional Robin Hood Garden, projetado nos anos 1960, foi a obra construída dos Smithson que sintetizava seus principios voltados ao social e à dentidade territorial. Em um grande lote, oconjunto piconposto de duas grandes lâminas de habitação, configurando um espaço interno que promove uma melhor qualidade 

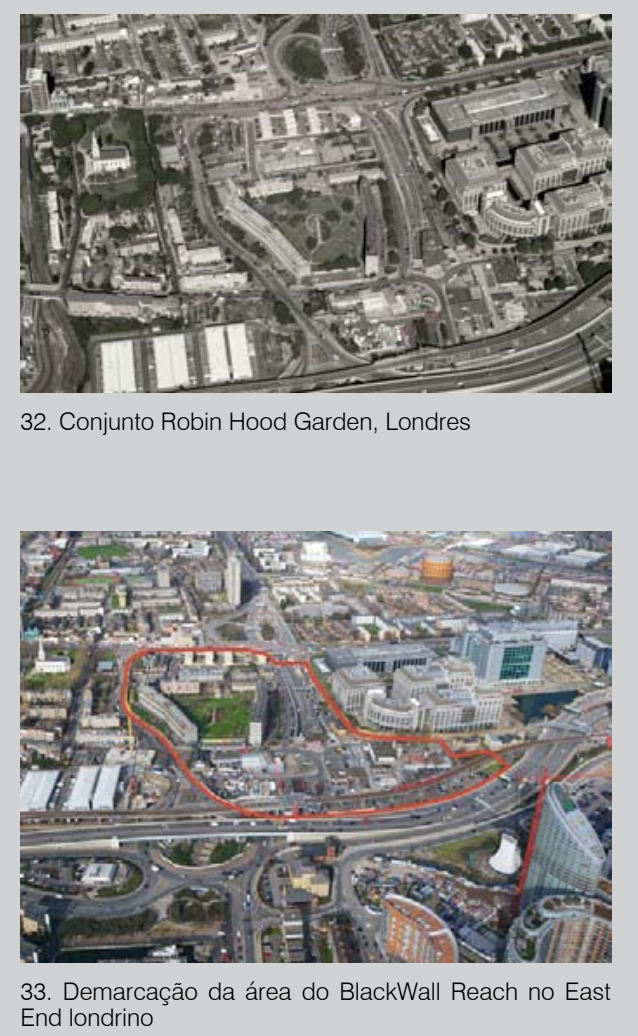

25 conjunto habitacional St. Prutit-1goe, em Saint Louis,
Missouri, projetado por Minoru Yamasaki (1912-1986)

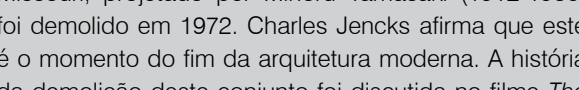

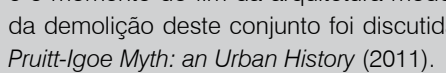

ambiental, protegida da intensidade de fluxos da região - o East End londrino, região cas instalaçoes portuarias da Companhia Britânica das Indias Orientais, que naquela ecca ainda tinha um forte carater industrial e uma quantidade grande de população de imigrantes.

Entre as principais questões enfrentadas pelo projeto, buscava-se criar a possibilidade de amenizar o impacto do tráfego e da poluição da vizinhança, dispondo a circulação comum às unidades nas fronteiras dos blocos e implantando, na face interna ao jardim, as cozinhas e os quartos, na expectativa de que isso gerasse a possibilidade de vigilância das mães sobre as crianças no jardim e destinando os dormitórios para a face interna, mais calma e protegida. (CRUZ, 2013, p. 8)

Também há uma intenção de sociabilidade na implantação das áreas comuns, com elevadores com paradas a cada três pavimentos e circulaçōes generosas, que promovem o encontro.

Os deques de circulação comum foram pensados como uma forma de realização da chamada "rua no céu" uma das principais apostas do casal Smithson. Trata-se tanto de uma referência às "ruas corredor" corbusianas da Unité de Marselha, como também uma tentativa de superação dessa referência. Os arquitetos espe ravam que sua proposta não permanecesse confinada ao interior do edifício e sim, promovesse uma maior interacão entre as unidades e a vizinhança. (CRUZ, 2013, p. 8)

A conclusão da obra, em 1972 coincide com um momento de revisão dessa tipologia de grandes conjuntos habitacionais - mesmo ano em que o conjunto Pruitt-lgoe, construído em Saint Louis, nos Estados Unidos, foi demolido, e que, para alguns autores, é um marco do fim do moderno ${ }^{25}$.

Desde a construção do Robin Hood Garden, a área em questão já era alvo de ações do mercado imobiliário. Grandes projetos urbanos de renovação são propostos próximos à área do conjunto, como o Cannary Wharf. Além disso, o brutalismo inglês estava ideologicamente vinculado ao welfare state:

Não somente na Inglaterra, como também na Escócia, assiste-se a uma constante desvalorização do legado brutalista, não ape-

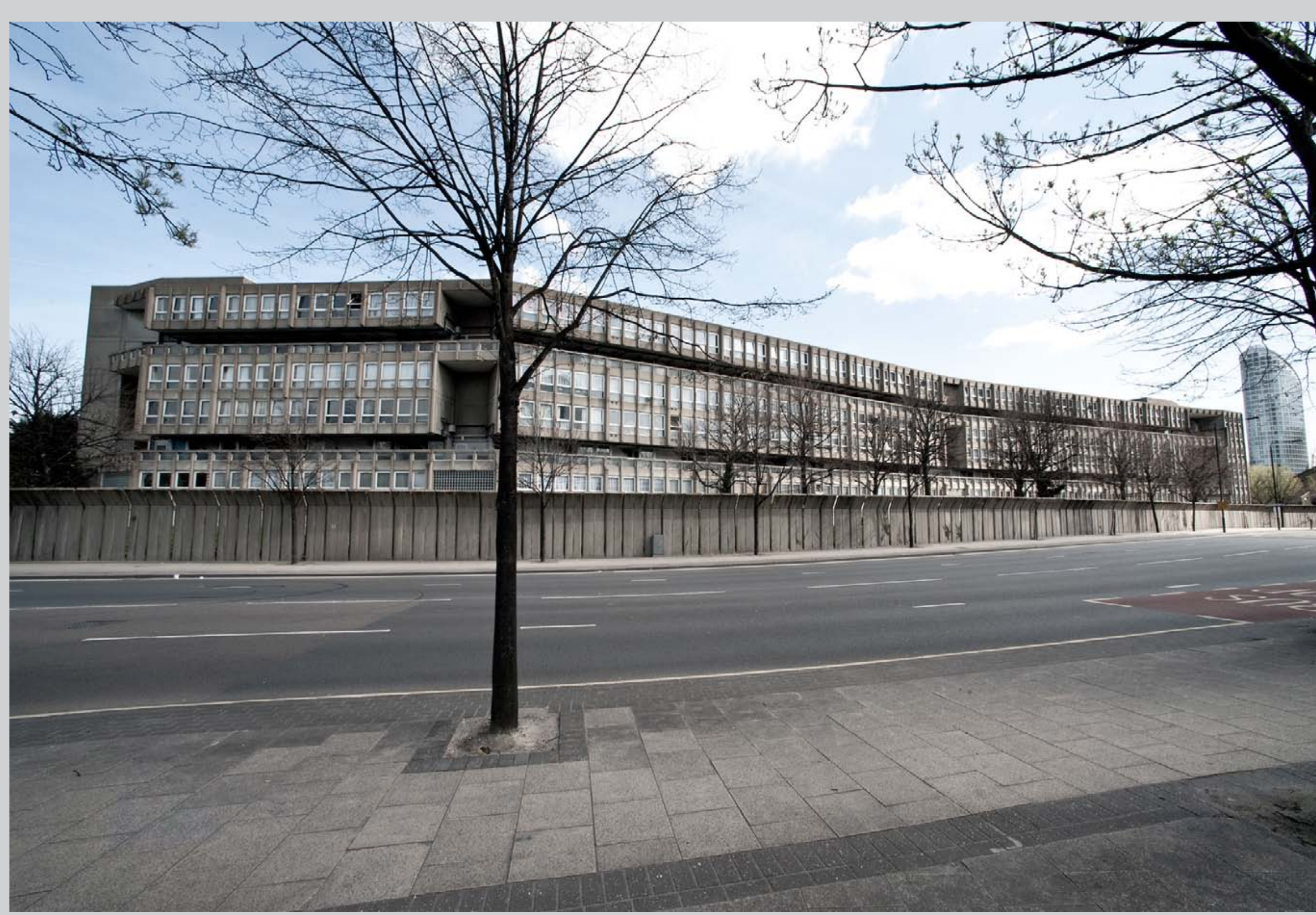

34. Conjunto Robin Hood Garden, Londres 


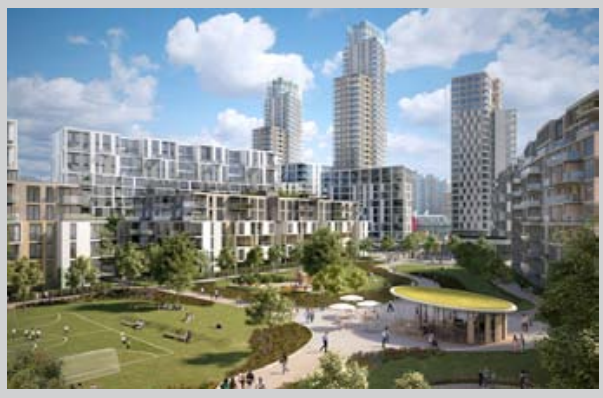

35. Imagem do BlackWall Reach na área do Conjunto
Robin tood Garden

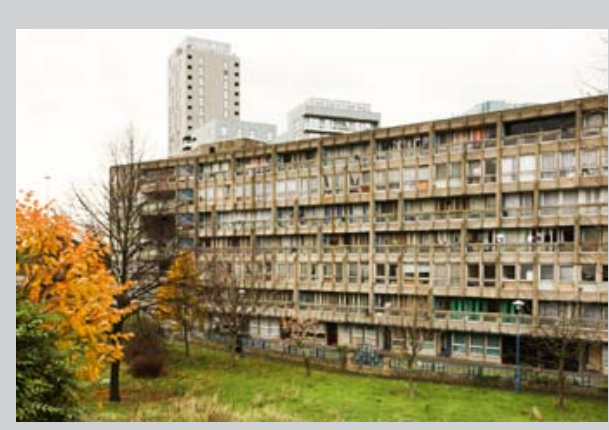

36. Coniuntit Robin Hood Garden com novos
enprenendimentos aot tund nas com a demolição de conjuntos habitacionais - vejam-se os casos do Heygate Estate em Londres, demolido em 2011, e do Red Road Flats em Glasgow, demolido em 2012 - como também de edifícios com grande caráter cívico, a exemplo da prevista demolição do Scottish Provident Building, em Edinburgh, ainda em discussão. Para não falar das constantes "renovaçōes" que visam basicamente a substituir $\mathrm{O}$ concreto aparente por revestimentos espelhados ou metálicos. (CRUZ, 2013, p. 8)

Em 2007, foi apresentada uma proposta de intervenção nessa área de Londres Parte desse novo empreendimento se dá exatamente no grande lote do Robin Hood Garden e considera a sua completa demolição. A obra intitulada Blackwall Reach Regeneration Project é vendida como: "One of the first developments in an exciting new regeneration area, Blackwall Reach will be fresh, fashionable and above all, differen Offering stunning apartments, beautiful open spaces, new shops and community facilities" 20

Um e-mail de Richard Rogers e Simon Smithson (filho do casal Smithson), enviado a arquitetos e entidades ligadas ao moderno, pede apoio a um abaixo-assinado para o tombamento do conjunto, mas até o momento não há nenhuma decisão a respeito ${ }^{27}$.

O jornal britânico $B D$ Online ${ }^{28}$ também promoveu uma campanha para a preservação do conjunto e, mesmo com a manifestação de seus moradores, tudo indica, no entanto, que em breve o Robin Hood Garden será demolido. una primeira etapa do novo empreendimento já está sendo construída e a segunda inclui justamente a área do

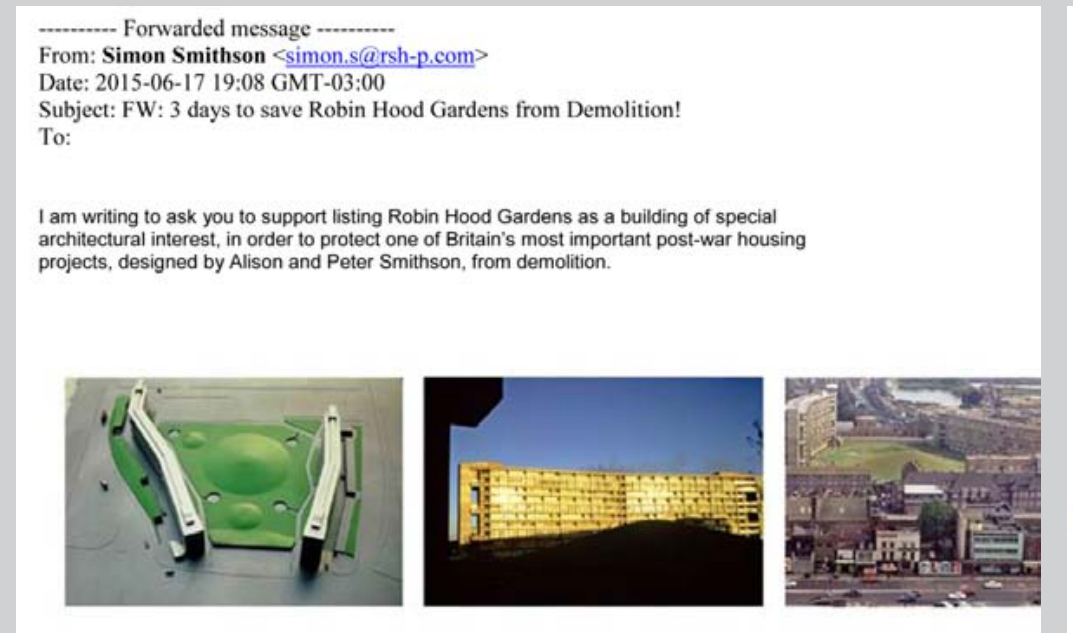

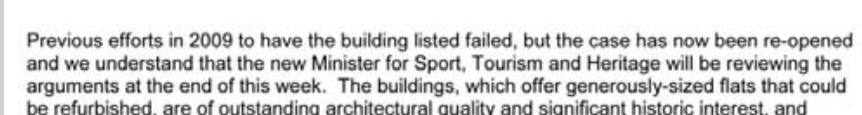

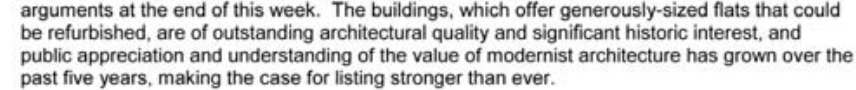

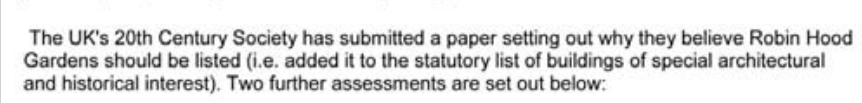

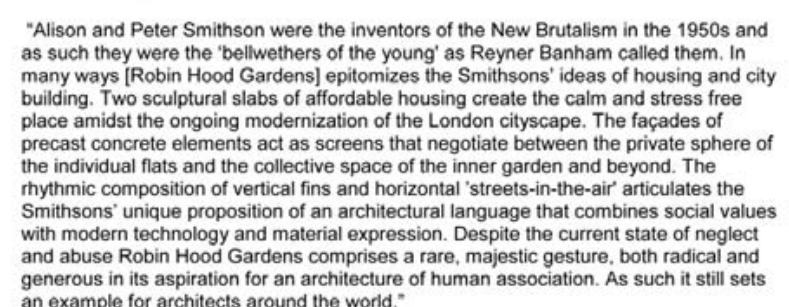

Dr Dirik van den Heuve, Deflt University, Hollane

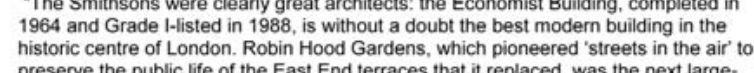

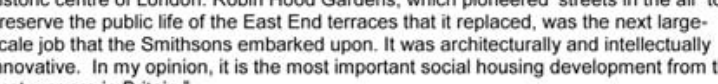

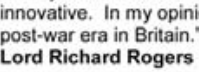

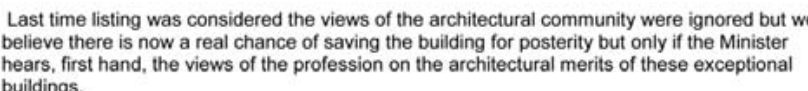

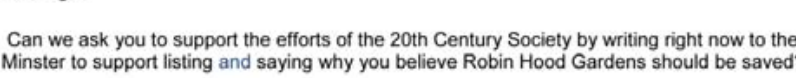

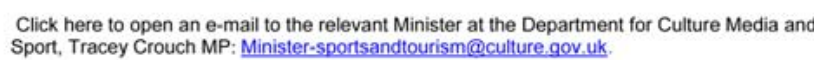

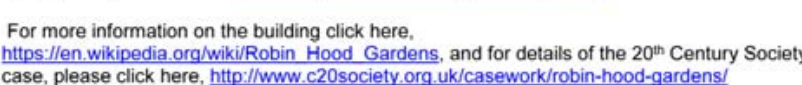

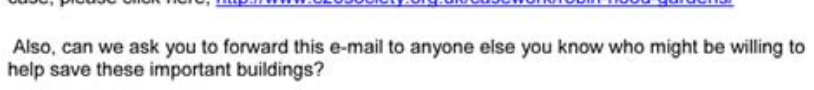

Yours saithuly,

Richard Rogers and Simon Smithson

Rogers Stirk Harbour + Partners
whwrsh- Doom

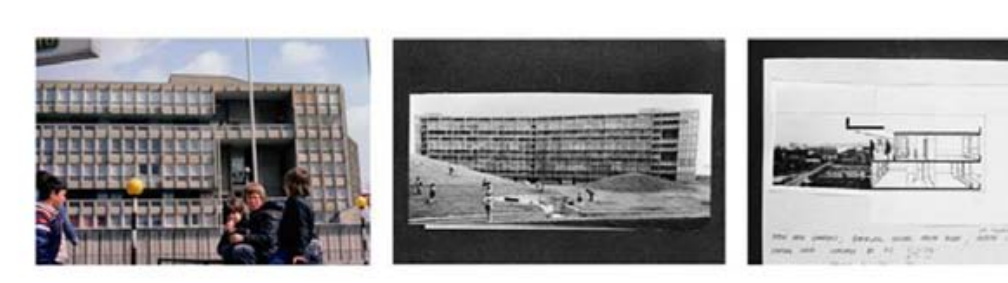

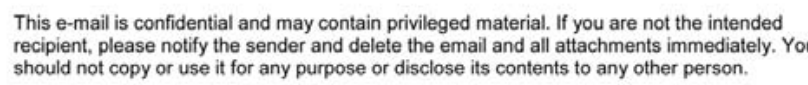

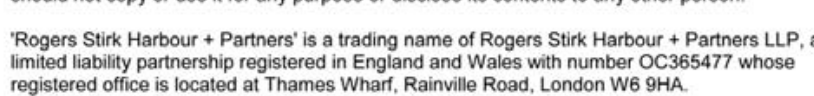




\section{Fábrica Peixe Duchen - Oscar Niemeyer}

O edifício industrial Peixe-Duchen foi projetado por Oscar Niemeyer e Helio Uchoa (1913-1971) nos anos 1950, às margens da Rodovia Presidente Dutra, que liga São Paulo ao Rio de Janeiro e passa por importantes polos industriais como Guarulhos, São José dos Campos e Taubaté. Tendo encerrado suas atividades industriais, o conjunto foi vendido no iń́cio dos anos 1980 e o novo proprietário pretendia usar o terreno para uma nova atividade. Para isso, precisava demolir por completo os edifícios industriais. Já com os prédios sem uso, um processo de tombamento foi aberto pelo CONDEPHAAT. Entre os diversos argumentos apresentados pelo novo proprietário para impedir o tombamento, há uma carta de Niemeyer afirmando que, sendo um edifício para uso espećífico e tendo perdido sua função, não teria nenhum valor a ser preservado. Essa carta foi fundamental no desdobramento do processo, que acabou com a demolição completa dos edifícios.

Apesar de não ter sido integralmente construído, foi reconhecido pela crítica como um relevante conjunto industrial, segundo Henrique Mindlin (1961, p. 218): "[...] in this design, also based on curving roof-lines, the structure, worked out by Joaquim Cardoso, is transformed into a daring investigation of the plastic possibilities of reinforced concrete", e está presente nas principais publicações que tratam da arquitetura moderna no Brasif . Oediffio recebeu o prim pub prescion na calegoria de edifícios industriais da $1^{\text {a }}$ Bienal de São Paulo, em 1951

Em 1986, o conselho do CONDEPHAAT aprova a abertura do processo de tombamento do conjunto - processo 14.896/86. Na justificativa de abertura, o arquiteto Marco Antonio Lopes Tabet constrói uma argumentação que se inicia com a importância de Niemeyer na producão da arquitetura e construção de uma identidade nacional e na especificidade da produção brasileira em relação aos modernos europeus.

Sobre o edifício propriamente dito esclarece que

[...] seu interesse formal se deve ao fato de que desde os projetos para a Pampulha, o arquiteto vinha realizando uma série de experimentos que estavam viabilizando sua ruptura formal com o racionalismo de Le Corbusier. Esses experimentos combinavam dois conceitos que até então eram vistos e entendidos em separado, a saber, a forma arquitetônica e a forma estrutural. Por isso, desde a Capela de São Francisco, encontramos no ARCO o centro formal das pesquisas de Niemeyer. [...] estruturalmente, o projeto da fábrica se baseia na articulação de dois pórticos
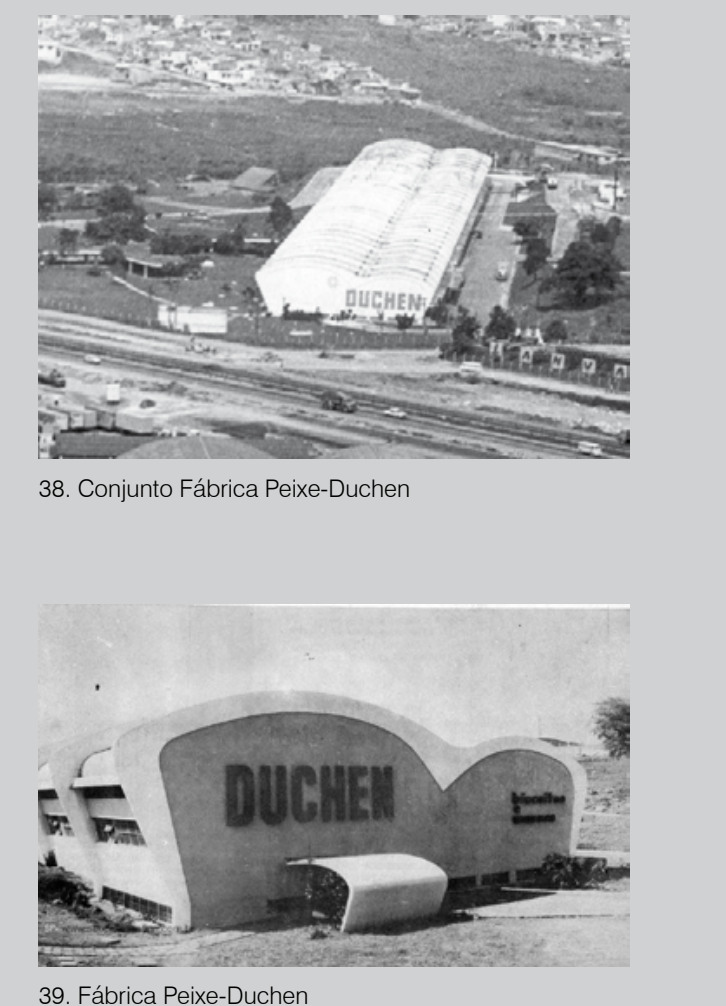

39. Fábrica Peixe-Duchen 
A construção do primeiro edifício, o bloco que vemos quando passamos de automóvel pela Dutra, foi feito de modo [a] aproveitar as curvas de nivel do terreno, evitando assim o movimento de terra. Por isso, o bloco principal fica em angulo para as divisas do lote, abrindo a vista alegremente para a Dutra, de onde pode-se ver a succssáo do pollcado a dar profundilade à modesta fachada. E, esse bloco, lambém serviria de pano -de -fundo para uma marquise curvilinea como uma "ameba", sob a qual estaria localizado o restaurante da indústria, de modo semelhante ao partido do restaurante dançante da Casa de Baile em Belo Horizonte. O segundo Bloco, náo construido, fora pensado tambem na forma de um porticado, muito à semelhança da Capela da Pampulha quando visto de frente. Estruturalmente, entretanto, sua solução era nova, derivada do bloco principal. A caixa d'agua e a portaria, esta unitma demolida, constiulam duas jolas modernas da brasilidade.

O segredo que tornou possível que o conjunto tão significativo viesse a ser projetado e, parcialmente construído, em São Paulo, está na linearidade do espaço interno que se permite pelo emprego da estrutura em pótrico: em funcão disso, a organização da linha de producão, que tinha nos fornos lineares seu maior problema, podiam ter uma soluça ótima, em termos de custo benefício. Comprimento (profundidade) e largura (vão) tinham no arco porticado sua melhor solução.

Desta maneira, como se vê, a fábrica Peixe-Duchen é muito mais importante do que se é dado ver. Foi publicada em todas as revistas de arquitetura brasileira que se prezassem na epoca. Também está publicada em Architectural Forum, Architecture d'Aujourd'hui, Progressive Archileclure [...] entre outras que podemos cilar. Foi o único projeto de indústria que Oscar realizou e, não por mera coincidência, tinha que estar em São Paulo.

Porfim quem não se lembra de tê la visto ao viajar pela Dutra? De marcar com sua passagem o início da viagem e de não encontrar 
As atividades industriais do conjunto se encerraram no início dos anos 1980. Em 21 de outubro de 1986, o jornal Folha de S. Paulo anuncia que a Empresa de Transportes Atlas havia adquirido o lote da Duchen, no qual pretendia aumentar o seu terminal de carga.

Inicia-se um processo na tentativa de inviabilizar o tombamento e, além da argumentação do fim da função do edifício, o grupo encaminha uma carta assinada por Oscar Niemeyer, na qual o arquiteto declara não reconhecer nenhum valor no conjunto

Fica evidente que, a partir da carta, as discussões tomam outro rumo. Em resposta ao recurso da empresa, o arquiteto Bernardo José Castello Branco, então chefe da seção de projetos do CONDEPHAAT, apresenta um parecer que recomenda

[...] o não tombamento, motivo do processo 24.896/86, devido particularmente a três questões:

$1^{\circ} \mathrm{O}$ aspecto fragmentário da obra ${ }^{30}$

$2^{\circ} \mathrm{o}$ atual estado de deterioração e retalhamento do seu terreno original

$3^{\circ}$ a necessária adaptação para um novo uso. (CONDEPHAAT, 1986, p. 68)

Ainda recomenda que "[...] o CONDEPHAAT providencie toda a documentação necessária, fotográfica inclusive e resenha histórica, completando os dados fornecidos na Informação Inicial, do arquiteto Marco Antônio Lopes Tabet, para salvaguarda da sua memória" (CONDEPHAAT, 1986, p. 68)

$\mathrm{O}$ arquiteto apresenta um conjunto de fotos que mostram o estado de conservação dos edifícios. O conjunto se apresenta íntegro, absolutamente legível com suas características principais preservadas.

Esses documentos geram grandes discussões no CONDEPHAAT . Há uma forte

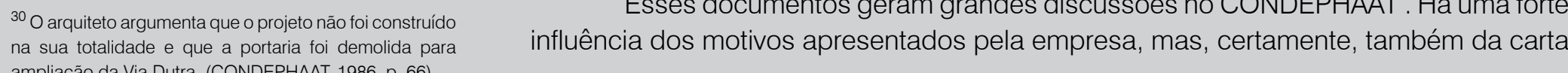

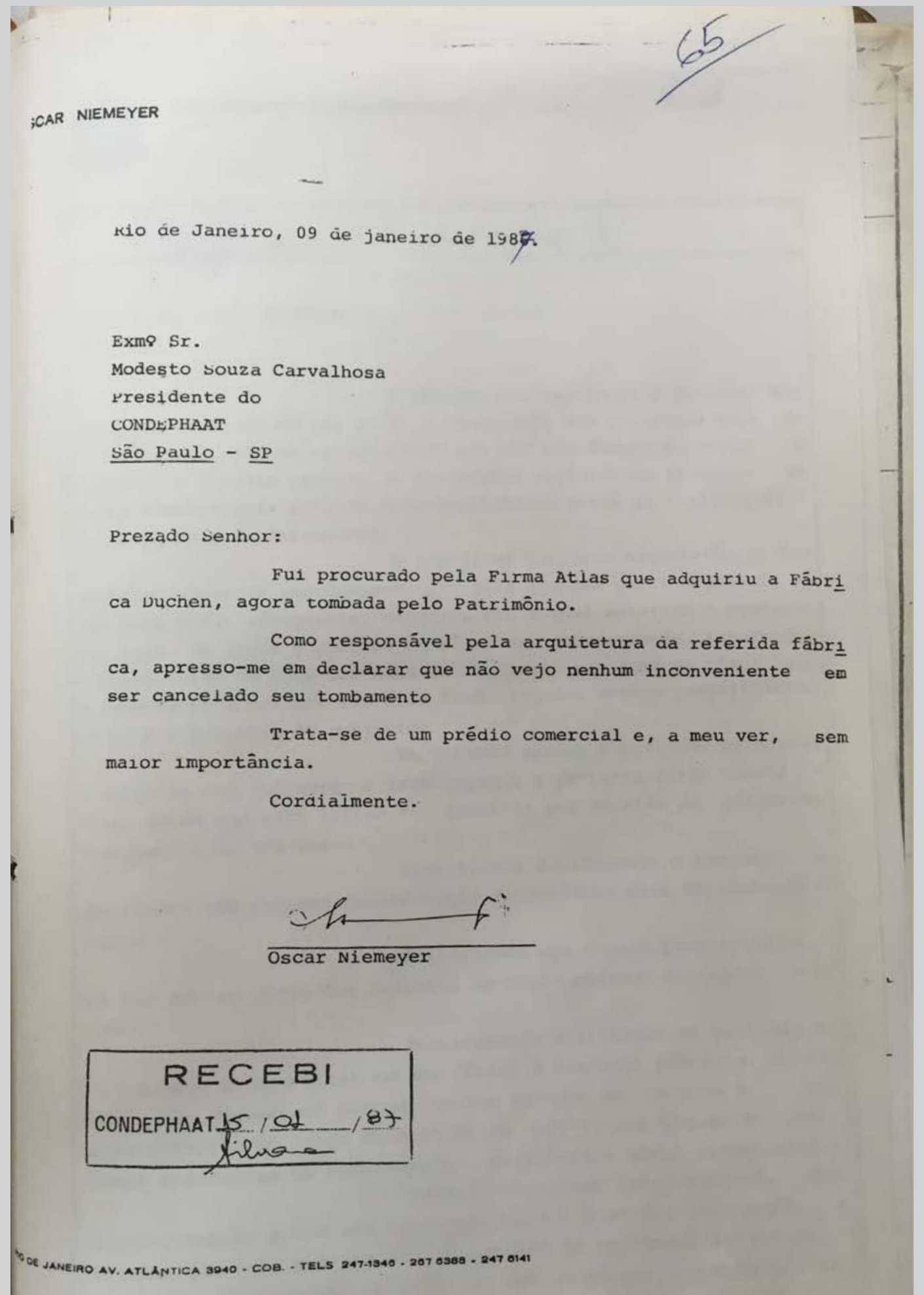

41. Carta de Oscar Niemeyer para o CONDEPHAAT 

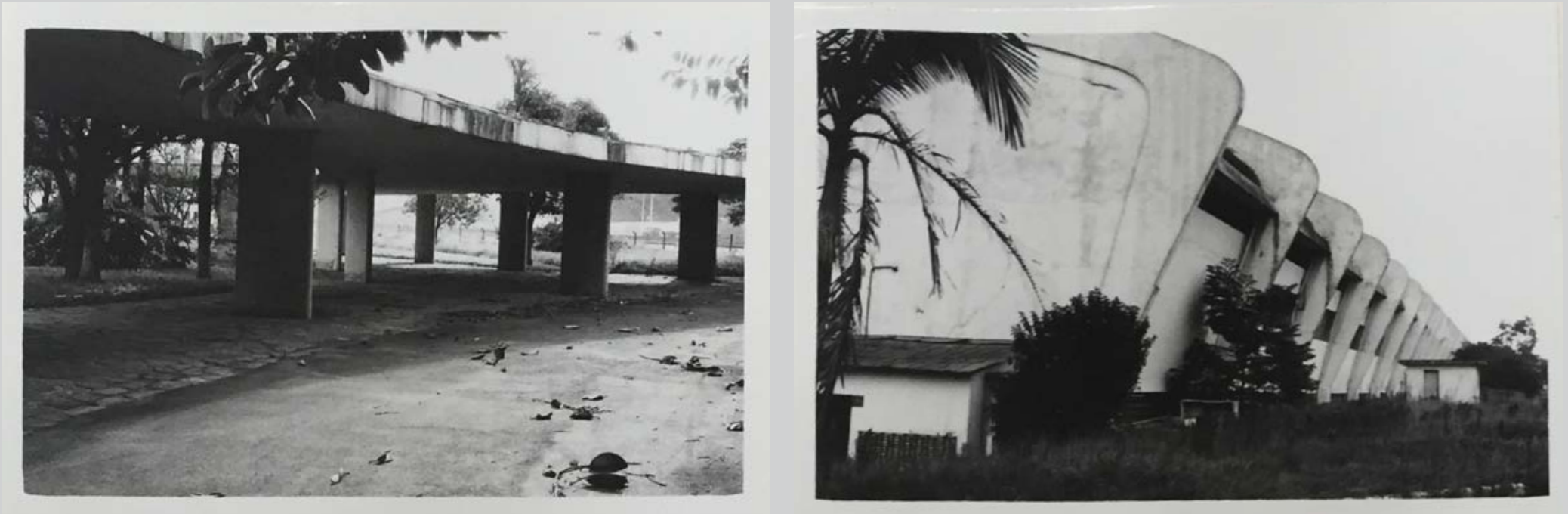

de Niemeyer, já que os argumentos levantados para o não tombamento são facilmente refutáveis, pois mesmo tendo um aspecto fragmentário ainda era possivel apreender o conjunto, além disso, a não conclusão do projeto não tira da obra construída o seu valor arquitetônico e histórico, e se mau estado de conservação fosse motivo para o não tombamento, pouquíssimos bens teriam sido preservados até hoje. Pelo contrário, o mau estado levanta a necessidade de proteger e pensar em política de restauro e qualificação da obra. Por fim a necessária adaptação a um novo uso nunca foi nem será motivo para o não reconhecimento - é o tipo de ação mais usual para preservação do bem, recomendada, inclusive pela Carta de Veneza.

Apesar do parecer contrário ao tombamento, o Conselho decide tombar o conjunto em sessão do dia 30 de novembro de 1987.

Em resposta ao recurso da Atlas e ao arquiteto Castello Branco, a conselheira Maria Luiza Tucci Carneiro retoma a discussão do Conselho, lembrando que os arquitetos Castello Branco e Carlos Lemos ${ }^{31}$ se posicionaram pelo não tombamento do edifício É importante lembrar que Lemos foi um dos principais colaboradores de Niemeyer em suas obras em São Paulo, o que faz com que seu posicionamento também tenha um peso relevante na discussão. Em 1977 na ocasião do aniversário de 70 anos de Niemeyer a Folha de $S$. Paulo fez uma série de matérias sobre o arquiteto e sua obra. Em um dos textos intitulado "Niemeyer faz 70 anos, triste com São Paulo" o argumento para a suposta tristeza era de que um grande número de obras do arquiteto na cidade sofreram alteraçães e segundo Lemos, já não possuíam as características originais dos projetos. Entre as obras citadas "[ . ] há o conjunto do ITA que o Oscar ganhou o concurso final, no fim da década de [19]40. Depois veio o prédio da Duchen de 1949/50,"32 É curioso notar como, muito provavelmente em função da manifestacão de Niemeyer a respeito do conjunto da Duchen, Lemos não reconhece valor nos edifícios industriais, dez anos após a declaração no jornal.

Carneiro, entretanto, ratifica a posição do conselho:

[...] por configurar-se como o importante espécime da linhagem de obras neimayerianas (sic), independente da opinião pessoal do arquiteto Oscar Niemayer (sic) ressalta que: o valor e o significado de um bem cultural está justamente no reconhecimento que a sociedade faz do objeto em questão. Por isto ele é "único" extrapolando em significado e ocupação ao nivel da memória coletiva. (CONDEPHAAT, 1986, p. 83) 
Na sequência, tanto a empresa como o arquiteto Castello Branco afirmam que

[...] se podemos recuperar e preservar um significativo exemplar histórico e arquitetônico em "seu original", não há porque sugerir [que] esse fique apenas "fotograficamente" registrado na memória da coletividade. Nesses casos, a resenha histórica e a documentação fotográfica devem subsidiar o restauro do edifício e não a sua demolição. Aí sim, estaremos colaborando pra salvaguardar a nossa memória já tão espoliada por interesses imediatistas e [] por que não, políticos. (CONDEPHAAT, 1986, p. 83)

O Conselho decidiu manter o tombamento do conjunto ${ }^{33}$. Iniciou-se, como é de praxe, uma discussão jurídica sobre a validade do tombamento. A empresa entrou com recursos, com argumentações pautadas no parecer de Castello Branco e enfatizou que o próprio autor não reconhece valor na obra.

Mais um conselheiro, o arquiteto José Carlos Ribeiro de Almeida, se pronuncia pela preservação da obra e desqualifica os argumentos da empresa; considerando inclusive que:

[...] não cabe ao Sr. Niemeyer julgar a importância de uma obra sua. Se Ihe foi dado o talento para projetá-la, e se esse talento se refletiu numa obra do significado da Fábrica Duchen, passou ela a compor o patrimônio da sociedade, passou [a] ser de domínio público. Sua atifude de declarar o bem como de pequena impor tância, é, no minimo, uma allude prosunçosa, por mais que 0 admiremos. (CONDEPHAAT, 1986, p. 125)

Em um telegrama, cuja data é desconhecida, o então presidente do Scontece definitivamentente após a tombamento, ele sò

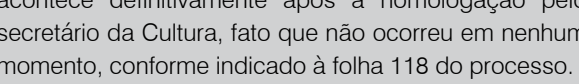

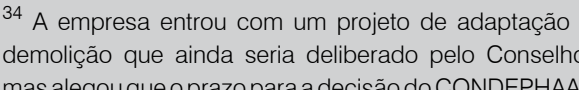
se extinguiu no recesso de jubho e decidiui iniciar as
obras sema devida autorizaçä (CONDEPHAT, , 1986 . . . 125) - năo há prazo estabelecido para deliberąąăo CONDEPHAAT, Edgard de Assis Carvalho, informa ao administrador da Regional da Vila Maria de que havia uma denúncia de que estavam sendo executadas obras no conjunto da Duchen e soliclia o embargo imedlato das demoliçoes em andamento e e de 1990

A empresa então alega que o terreno havia sido ocupado por moradores de rua mento ${ }^{34}$ a falta de conservação, iniciou-se um processo irreversível de deterioração e e desabamento da estrutura.

Um laudo datado de setembro de 1990, elaborado pelo Departamento Estadual de Polícia Científica, atesta o estado de ruína do conjunto e as fotos apresentadas conde Polícia Científica, atesta o estado de ruín
firmam, de fato, uma situação irrecuperável.

A comparação entre as fotos de Castello Branco, de 1987, e as do laudo, de 1990, mostram um estado de arruinamento impensável para uma estrutura de concreto daquele tipo, mesmo com a alegada falta de conservação. A justificativa de se tratar de uma estrutura frágil que, por ter grandes vãos e problemas nas juntas de dilatação, teria se arruinado, parece omitir uma intenção deliberada pelo desmoronamento - ou demolição? - do conjunto.

Um acordão de setembro de 1991 do Tribunal da Justiça decide dar ganho de causa à Empresa Atlas, de causa à Empresa Atlas, sendo que um

Em 22 de fevereiro de 1992, em documento cuja assinatura não é identificada, consta:

O E. Colegiado, na referida sessão de 06.07.92, propendeu pelo cancelamento do tombamento dadas as condiçōes aludidas retro, com a mantença, no imóvel, de arcos que restariam remanescentes e tomada de medidas punitivas. Contudo, em conversação que mantive com a Atlas, proprietária, na pessoa de seu advogado, ficou combinado que o colega me enviaria cópia do inquérito criminal instaurado por representação nossa, já arquivad os arcos já foram demolidos após a publicação do Acordão do TJ que em suma levantou a probição das obras demolitórias dando provimento ao recurso da Atlas, com o que se pôs termo à ação cautelar do douto M. Público. (CONDEPHAAT 1986, p. 180)

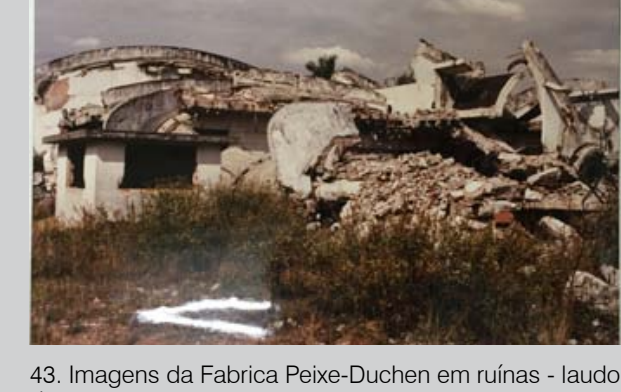

43. Imagen 10
de 1990
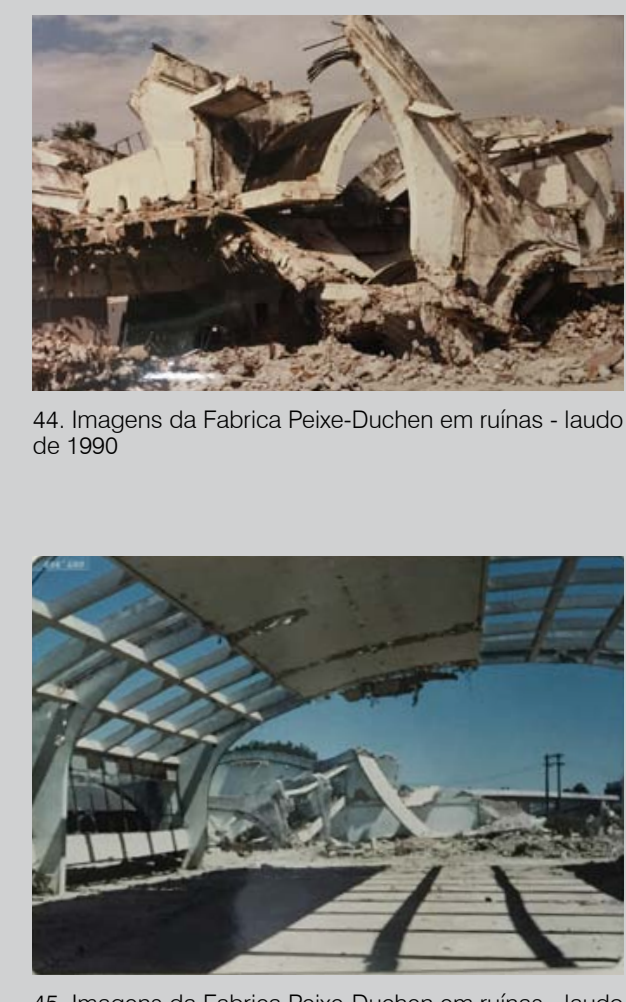

45. Imagens da Fabrica Peixe-Duchen em ruinas - laudo

Essaquestä́o mostra o desconhecimento dos trâmitites

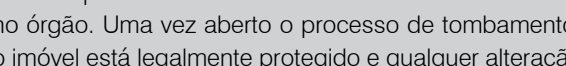

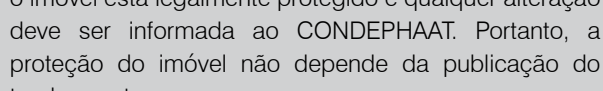


O edifício sede da Sociedade Harmonia de Tênis, tombado pelo CONDEPHAAT (SC 34/1992) e pelo CONPRESP (TEO Res. 31/1992), foi projetado pelo arquiteto Fábio Penteado (1929-2011) em parceria com os arquitetos Alfredo Paesani (1930-2012) e Teru Tamaki (1934-2013), em 1964. A edificação, concluída em 1970, se insere na chamada "Escola Paulista" ou "Brutalismo Paulista" (BRUAND, 1977, p. 269).

O edifício apresenta toda a sua solução em um bloco único destacado do chão, reunindo um jogo de níveis que define sutilmente os usos do espaço e permite sua flexibilização e renovação, sempre buscando a horizontalidade e a transparência. Esta transparencia proporcionada pela grande estrutura em grelha apoiada em doze pilares periféricos, que a partir de seus balanços e fechamento em vidro permite a continuidade do interior e do exterior do prédio, seja alravés dos jardins e area da piscina, seja através da praça de acesso e sua relação com a rua

Outra característica típica do brutalismo paulista marcante nesse edifício é o jogo de iluminação zenital proveniente da grelha de cobertura. Toda a parte de servicos é concentrada no subsolo do edifício, decisão de projeto que reitera o partido da permeabilidade dos espaços nas diversas cotas térreas, sem interrupção por volumes fechados.

Sua materialidade é composta com base em quatro elementos: o concreto aparente, o piso em madeira, o vidro e a lona laranja utilizada nos brises. Esse edifício resulta da combinação de espaços simples e núcleos funcionais, concebidos a partir

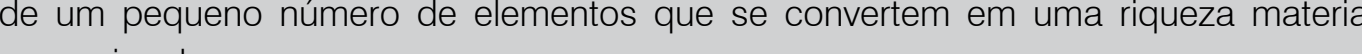
excepcional.

O arquiteto-autor, sócio do clube, foi sistematicamente consultado sobre as intervenções que foram realizadas ao longo do tempo no edifício. Nesse caso, o arquiteto foi extremamente cuidadoso com sua obra: mesmo em intervenções mais complicadas, como a necessidade co instalação de elevador para adequacão à acessibilidade universal, os valores reconhecidos no edifício foram respeitados. A instalação do elevador tinha poucas opções de localização em que pudesse atender aos níveis intermediários do edifício. Assim, o local escolhido exigiu o rompimento do peitoril de concreto do pavimento superior. Outras intervenções, como a instalação do sistema de ar-condicionado e alteração do bar foram absolutamente respeitosas com edifício.
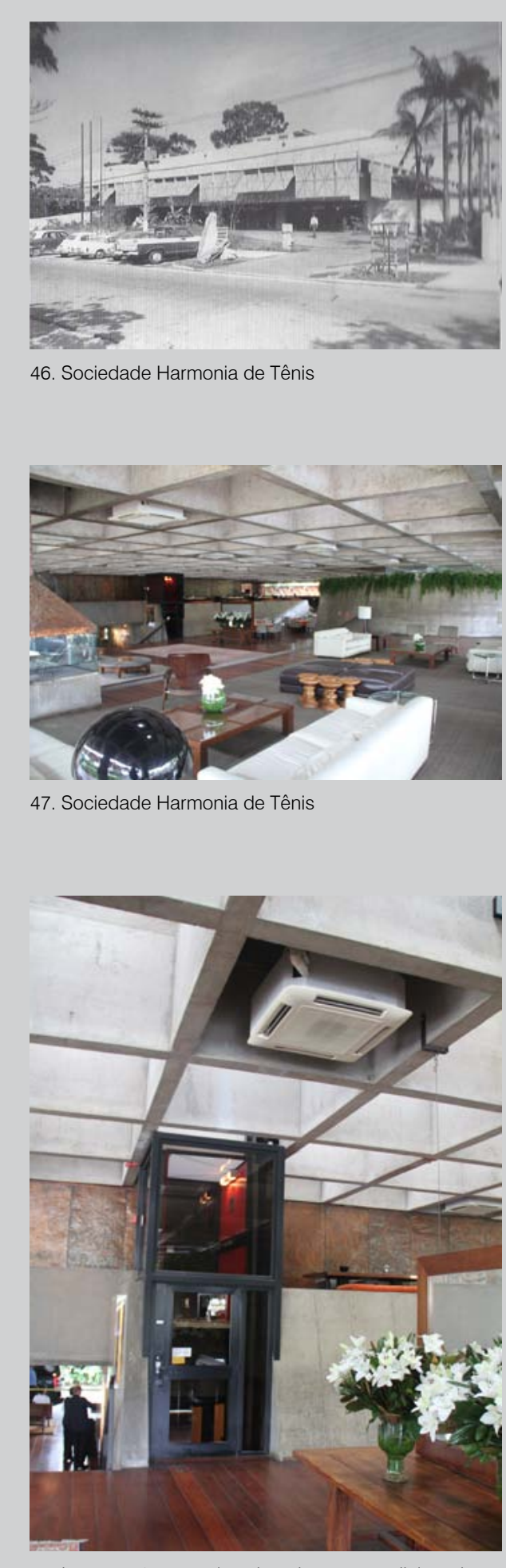

48. Intevennąăo posterior, elevador e ar-condicionado 


\section{Intervenções no moderno}

Reconhecidas as obras, as questões que se colocam são de outra ordem. Como preservar edifícios tão recentes, construídos com tecnologias ainda atuais e materiais disponíveis? Nas abordagens da arquitetura moderna é evidente a dificuldade de se trabalhar com a passagem do tempo, o envelhecimento e problemas provenientes da experimentação tecnológica - conceitos absorvidos ao longo do século XX, com base nos escritos de Alois Riegl, e que estão incorporados aos princííios do restauro-crítico.

Apesar do extenso reconhecimento oficial a partir de tombamentos, ainda é possivel identificar uma enorme quantidade de intervenções com duas abordagens distintas: as pragmaticas, que não consideram os valores atribuidos, comprometendo sua transmissaáo como parimontio cullural, e as de repristinação, que não aceitam a passagem do tempo incorporada aos edifícios.

Carbonara (1997, p. 286) faz uma importante distinção no que diz respeito à recuperação da imagem de uma obra em um trabalho de restauro: "[...] si tratta quind d'intendere il restauro come azione mirante al recupero della vera immagine dell'opera che, come vedremo, può essere cosa diversa dallimmagine originale e non ha nulla a che fare con le tentazione della vecchia 'unità di stile'"

Algumas realidades normativas, como França e Itália, estipulam parâmetros temporais para o tombamento, exigindo um mínimo de antiguidade. No Brasil, não hă nenhum tempo estabelecido, ou seja, uma obra recém-concluida ou até mesmo não terminada pode ser tombada ${ }^{30}$. Independentemente de questóes legais, 0 reconhecimento do moderno é recente, e considerando o intervalo entre a produçáo e reconhecimento evidencla-se um cunto espaço entre as duas. Esse e um dos principals

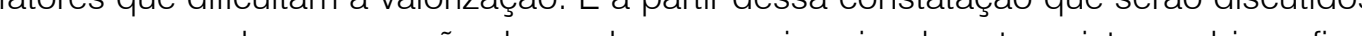
projetos e obras construídas

Não é privilégio da produção moderna a assinatura de projetos; pelo contrário, desde tempos remotos os edifícios têm em seus autores um ponto de destaque, mas a relação que atualmente se estabeleceu com os grandes nomes da produçấo arquitetônica do século XX tem interferência direta na sua preservação, diferentemente de edifícios de épocas anteriores.

São duas as abordagens principais: a consulta a arquitetos-autores, membros de sua equipe ou familiares que se posicionam como habilitados a intervir nas obras devido seriam, tambén e repristinaçōes. Como aponta Küh:
Para as obras icônicas, em geral vinculadas ao movimento moderno - em que se chega a extremos de nem mesmo buscar o suposto estado original as built (como de fato construído), mas o estado as published, como divulgado através de fotos e projetos da epoca da construção, ou mesmo refazer uma obra desaparecida segundo projeto original -, até manutençōes e modernizaçōes desrespeitosas em relação aos aspectos documentais e formais das obras, algo que acomete sobretudo algumas expressōes da arquitetura mais recente, constrú́das no segundo pós-guerra ou obras anteriores, não modernas. (KÜHL, 2009, p. 95)

Essas questões colocadas por Kühl revelam, também, uma crise na produção da arquitetura. Se desde a segunda metade do século XX as preexistências são incorporadas nos discursos dos arquitetos, observa-se que o campo da preservação e restauro ainda carece de aprofundamento nas atividades de projeto. As abordagens mais comuns, no sentido da repristinação, evidenciam a dificuldade de se trabalhar em
diálogo com os edifícios e seus autores. É um processo de submissão que em nada contribui para a preservação e tem um forte caráter nostálgico, como aponta Simona Salvo (2016, p. 77):

Nel migliore dei casi, pertanto, si perseguono motivazioni culturali per recuperare quel valore simbolico che la letteratura critica ha riconosciuto all' opera ma facendo un uso pretestuoso delle fonti documenlane eratlandoconscas pur di raggiungere un antistorico "purismo formale"

Há uma questão burocrática que poderia ser um contra-argumento à discussão colocada neste trabalho. Trata-se de como cada país aborda o direito do autor. Cada legislação estabelece regra-se de como cada pais aborda o direito do autor. Cada sua obra caso ela tenha sido reconhecida com valor artístico - "[...] se all'opera sia sua obra, caso ela tenha sido reconhecida com valor artístico - [...] se all opera sia all'austore lo studio e l'attuzzione di tali modificazioni,37 No Brasil, a lei que regulamenta o direito autoral estabelece que:

Art. $5^{\circ}$ Qualquer projeto ou trabalho técnico de criação só poderá ser repetido com a anuência do detentor do direito autoral patrimonial correspondente, respeitados os direitos autorais morais do auto 
Art. $6^{\circ}$ Para os efeitos desta Resolução considera-se: I-Repetição indevida: reprodução integral de projeto ou outro trabalho técnico de criação em Arquitetura e Urbanismo, realizada em desacordo com o art. $5^{\circ}$ desta Resolução e efetuada por pessoa física ou jurídica que é titular de algum direito patrimonial sobre a obra intelectual; II - Cópia: reprodução integral de projeto ou outro trabalho técnico de criação em Arquitetura e Urbanismo, efetuada por pessoa física ou juŕdica que não é titular de nenhum direito patrimonial sobre a obra intelectual. ${ }^{38}$

Observa-se, no entanto, que a legislação vigente se mostra absolutamente inviável. Numerosas reformas são feitas sem nenhum tipo de consentimento de arquitetos-autores. No caso do patrimônio, um dos argumentos poderia ser que, pelo valor cultural, deveria ser obrigatória essa consulta.

O caso da legislação brasileira, que atribui o direito autoral inclusive à pessoa jurídica, incentiva as ações de preservação dos escritórios de determinados arquitetos que ficam legalmente autorizados a atuar em nome de seus autores, o que remete à discussão colocada no capítulo anterior.

Este trabalho não abordará o tema a partir dessa demanda burocrática, mas a partir da discussão sobre preservação que, em alguns casos, poderá ir de encontro às legislações citadas.

\section{Edifício Pirelli - Gio Pont}

Um exemplo dessa questão foi o restauro da fachada contínua de vidro e alumínio do Edifício Pirelli, em Milão, projetado por Gio Ponti (1891-1979). A edificaccão fo inaugurada em 1958, transformando-se num marco na paisagem da cidade. O edifício de 33 pavimentos foi construído com estrutura em concreto armado e sua fachada tem enormes panos de vidro e alumínio, uma grande inovação para a época.

Em função do estado de conservação da fachada, que passou quase cinquenta anos sem manutenção, um grupo de especialistas sugeriu a substituição de toda a sua estrutura por um sistema novo, contemporâneo, de excelente desempenho. Depois do choque de um monomotor contra o edifício em 2002, novos estudos foram feitos. A equipe de arquitetos responsável pelos trabalhos de restauro da fachada propôs tratar os montantes e painéis de alumínio originais - que ainda tinham boa condição estrutural e apresentavam desgastes aceitáveis - colocar vidros duplos com câmara de ar para melhor isolamento térmico (em vez de simples, como era originalmente) realizar pequenos ajustes nas peças de vedação, interferindo minimamente no sistema realizar pequenos ajustes nas peças de vedação, interferindo minimamente no sistema original e atingindo ótimo resultado técnico. Assim, preserva-se a inovação do projeto,
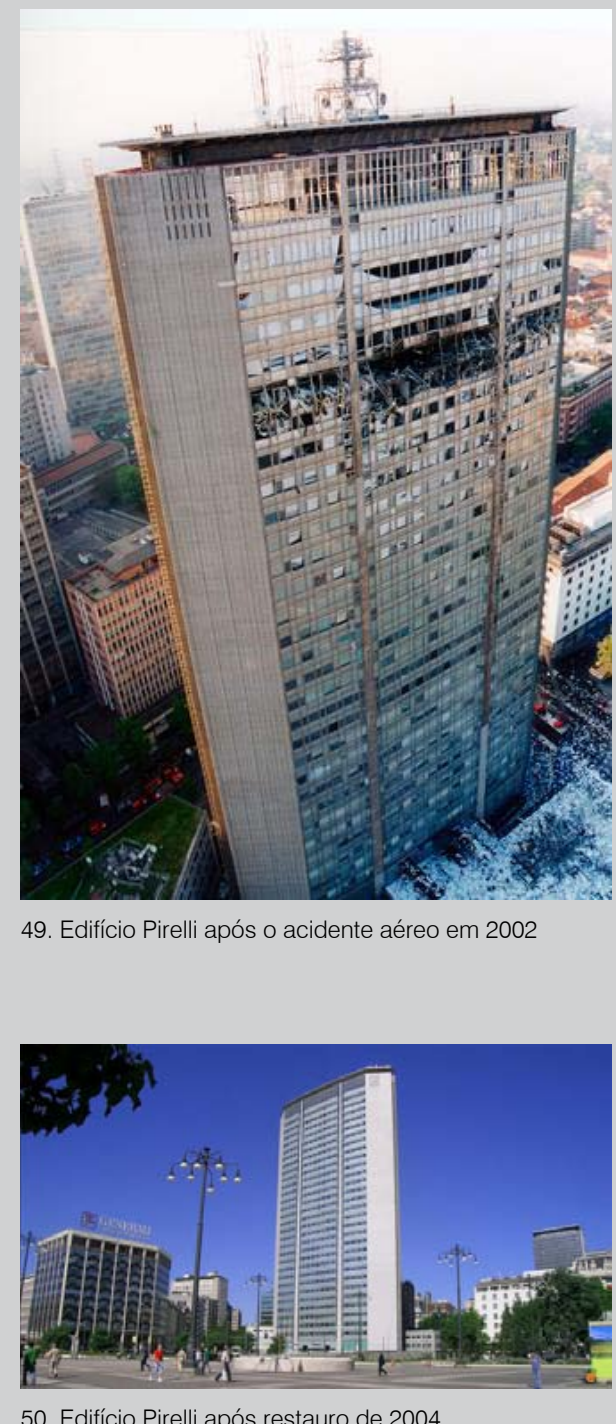
39 Sobre orestauro do Edificio Prielli ver KÜHLL (2005) 


\section{Mitificação}

Apesar de partir do ponto contrário ao que foi exposto anteriormente, ou seja, do reconhecimento contundente do valor da arquitetura moderna, a importância atribuída em alguns casos não se dá somente pela preservação de patrimônio cultural, mas de um olhar mitificado construído pela crítica e pela história da arquitetura. Assim, as relações com os autores, equipes, herdeiros e documentação também são colocadas, mas de forma distinta. Há, nesses casos, a constante busca de uma suposta originalidade e de uma aparência de obra nova que nega o passar do tempo. Ações de repristinação que se pautam por justificativas questionáveis e colocam a preservação em cheque.

Segundo Salvo (2016, p. 79):

[...] dal ripristino più spinto al conservatorismo feticista, dalla condanna del passato al suo spasmodico revival, si verificano imprevisibili corto circuiti fra Storia e vicende personali, che consentono la scesa in campo dí quelle già enunciate "affinità elettive" generate da relazioni personali, a volte affettive, altre intellettuali, altre professionali, ma comunque determinant nell'orientare l'intervento.

Uma busca incessante pela imagem idealizada desta arquitetura, que nesses processos, ainda segundo Salvo, passa a ter como principal valor a sua imagem desvinculada de processos historicos, sociais e culturais: "Larchitettura non e piu oggetto collocato nel tempo e nello spazio ma diventa modello di sé tessa" (SALVO 2016, p. 27).

Para isso, desconsideram-se vários aspectos construtivos e de contexto ou as decisões são amparadas na justificativa da existência de projetos executivos. Ambos os casos serão discutidos adiante, mas no que diz respeito ao reconhecimento dos bens como patrimônio, levanta-se uma discussão específica: estaria sendo construída uma nova abordagem do patrimônio, específica para o moderno, que nega a construção teórica desenvolvida até o momento? Quais as reais intenções desse tipo de postura?

Uma delas parece ser, efetivamente, a dificuldade de aceitar o fim da proposta moderna que pretendia uma transformação radical na sociedade, na cidade e na arquitetura, e que essa importante produçāo do seculo XX teve conquistas relevantes, mas se encerrou como mais um ciclo da historia. Há um deliberado interesse em da produção em série como tendo alcançado o ponto máximo de uma evolução da arquitetura. Contrária, inclusive, às propostas que, desde pelo menos Riegl, negam os sucessivos movimentos artísticos e históricos como um processo de desenvolvimento, e que evitam uma leitura hierárquica deles.

As obras assumem um caráter mítico, inacessível, que acaba por prejudicar a sua preservação de forma adequada. Há uma dupla possibilidade de abordagem: por um lado, uma compreensaao de "intocabilidade", na qual novos usos e demandas contemporâneas são prejudicados em nome de uma suposta condição original; por outro, açōes que buscam resgatar una condiçáo supostamente original, vinculada à imagem consagrada da obra, conforme discutido anteriormente.

Simona Salvo (2016, p. 11) destaca que "I principi de serialità, transitorietà e fragilità che hanno programmaticamente indirizzato la produzione dei manufatti, pur raramente posti in atto, inducono a ritenere legittimi copie e ricostruzioni". Evidentemente, a justificativa de ações de repristinação a partir do ideário moderno da industrialização da construção mostra ser frágil, posto que vários dos edifícios modernos preservados não partem desse princípio A ideia de produção em série está vinculada principalmente à questão habitacional e industrial. Utiliza-se de forma inadequada o conceito, a fim de justificar essas ações de repristinação e novas construçōes a partir de projetos. Basta verificar quais os casos de novas construções com'era, dov'era ou de "restauros" que recuperam uma suposta imagem original, como o caso da Vill a Savoye (citado anteriormente) para perceber que não se trata de obras que operam baye (citado princípio de série. Assim, a ideia do falso, conforme estabelecido por Brandi, contribui para localizar essas obras no seu devido lugar jé que "[ - ] o falso poderá espellhar a forma particular de ler uma obra de arte e de inferir o estilo que foi próprio a um dado período histórico" (BRANDI, 2004, p. 116). Assim, passa a ser essencial desvincular-se e ter o devido distanciamento do discurso dos arquitetos e teóricos modernos do ińcio do século XX para não cair em anacronismo, afastando-se de armadiha da militância que aquele momento exigia.

Entretanto, em um trabalho de restauro, as decisões no projeto correm sempre o risco de estar no limite entre restauro, conservaçáo e repristinaçao, conforme Carbonara (1997, p. 274): "[...] fino a quale punto il restauro deve mirare a ristabilire l'unità $e$ l'integrità dell'opera in quanto immagine senza commettere un falso artistico o storico e senza cancellarne le trace del passaggio del tempo?. Para o patrimônio recente, essa questão ganha maior complexidade pela possibilidade de utilização no restauro dos mesmos materiais e tecnologias empregados na construção. Esse limiar é sempre bastante tênue.

Uma vez construída, a obra tem especificidades locais irreprodutíveis tais como o tipo de solo, a orientação, a topografia e, principalmente, o contexto ambiental, socia 
é condicionada pelo entorno e, por sua vez, o ambiente como um todo passa a ser percebido a partir, também, da presença da obra ${ }^{40}$

Além disso, para aqueles que em algum momento acompanharam qualquer construção por meio de projetos extremamente detalhados, é evidente que decisões de obra, in loco, não são registradas nos desenhos e, muitas vezes, são incorporadas ao edifício sem nenhum registro.

Fotos, desenhos e croquis também têm as suas armadilhas. Qual autor divulgaria imagens dos problemas das suas obras? Dos ângulos menos privilegiados? Obviamente as imagens são escolhidas a fim de mostrar o que há de melhor, de mais elaborado, que confirme o discurso a ser incorporado ao edifício.

Nem de longe se trata de ignorar esses documentos como importantes fontes de informação sobre os projetos. São essenciais para a sua compreensão como um todo e tambem para amparar os estudos de um eventual projeto de conservaçáo ou restauro. Mas sua leitura demanda cuidados, ou seja, do ponto de vista epistemológico, a crtica das fontes sáo úteis no sentido de entender do que toi proposto, mas náo garantem, em hipótese alguma, que o que foi construído é rigorosamente o que está representado.

Soma-se aisso o fato de que, segundo o restauro-crítico, éessencial compreender os processos e as camadas históricas que se sobrepõem continuamente; fatos que não estão incorporados ao projeto, sendo legíveis apenas no objeto construído.

Os casos a seguir mostram a dificuldade de trabalhar com os edifícios modernos sem se contaminar pelos discursos e pelas relações com os arquitetos-autores e seus projetos

\section{Weissenhofsiedlung - varios autores}

Le immagini recenti delle architetture di Mies van der Rohe, Oud, Stam e soprattutto di Le Corbusier alla Weissenhofsiedlung di Stocardacimostrano opere tutte accuratamente e "filologicamente" rimesse a nuovo, come se si trattasse di costruzioni odierne e come se il tempo, più di mezzo secolo, quanto mai denso d'avvenimenti, non fosse passato. Quest'esibita assenza di storicità, questa restituita presenza a-temporale sono un bene e si traducono, sul piano culturale, in un arricchimento oppure costituiscono un limite, una carenza intrinseca al paziente lavoro di ripristino condotto da un decennio a questa parte? (CARBONARA, 1997, p. 390)

Giovanni Carbonara inicia com a pergunta mencionada na citação o capítulo que trata do "restauro do novo" em Aw/icinamento al restauro (1997). Evidencia, logo nas primeiras linhas, a dificuldade de abordar o tema e usa como exemplo o reconhecido conjunto construído na Alemanha, com plano de Mies van der Rohe (1886-1969), e os projetos dos edifícios dos mais renomados arquitetos modernos da época, como Peter Behrens Victor Bourgeois, Le Corbusier, Pierre Jeanneret, Richard Däcker. Josef Frank. Walter Gropius, Ludwig Hilberseimer, J. J. P. Oud, Hans Poelzig, Adolf Rading Hans Scharoun, A. G. Schneck, Mart Stam. Bruno Taut, Max Taut e Ferdinand Kramer. Cada arquiteto apresenta questões diferentes tanto do ponto de vista espacial como construtivo.

Segundo Benevolo (2006, p. 458):

[...] a exposição de Stuttgart apresenta ao público, pela primeira vez, um panorama unitário do movimento moderno. O confronto direto entre obras de muitos arquitetos, provenientes de várias naçöes, evidencia os propositos comuns mais do que as diferenças e loma vistul a convergencla substanctul en que muitas pesquisas que têm origens diversas. Não existiu um projeto de conjunto, e os varios edilicios esláo simplesmente colocados um ao lado do outro, tal como nos balisos periericos comuns. Se se refletir, contudo, no fato de que os edifícios são pensados como protótipos, adequados para serem repetidos em série e que valem, em um certo sentido, como amostras de bairros correspondentes, o Weissenhof pode ser considerado como uma representação

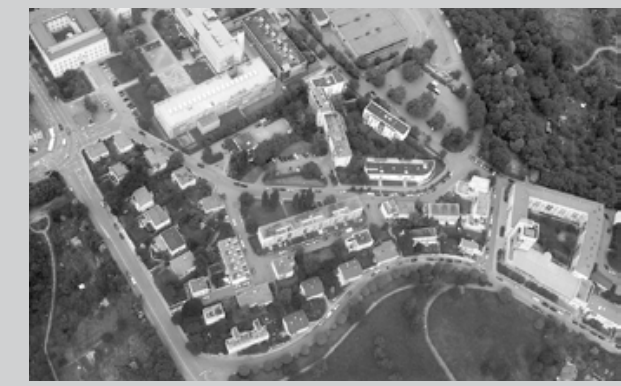

51. Vista aérea do Weissenhofsiedlung Stuttgart, 2004
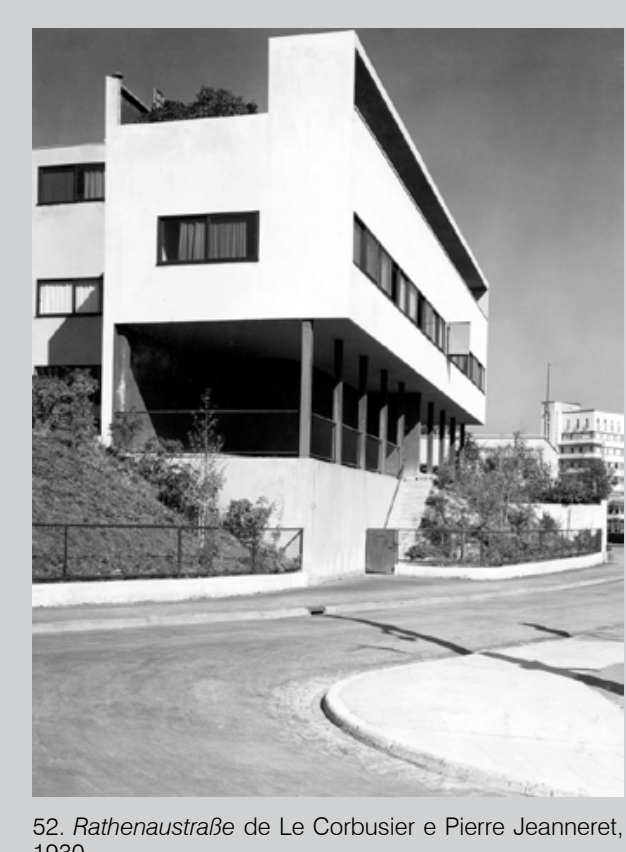

52. Rathenaustrabe de Le Corbusier e Pierre Jeanneret.

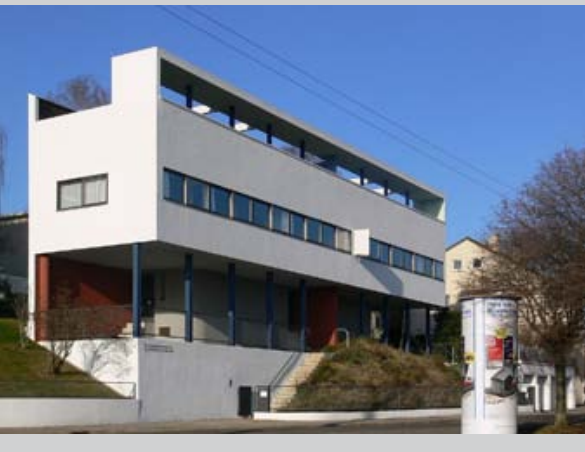



diversos modos de projetar.

O processo de restauro foi conduzido por uma comissão constituída em 1977 na prefeitura de Stuttgart, devido à pressão de uma associação chamada Freunde der Weissenhofsiedlung ${ }^{41}$, presidida por Bodo Rasch, arquiteto que participou de alguns projetos de interlores de apartamentos da Weissenhot? Os trabahos se iniclaram en 981.

A revista $D O M U S^{43}$ publicou uma grande matéria sobre o restauro do conjunto, questionando os princípios que o nortearam. Logo no subtítulo, já levanta a questão de se tratar de um olhar mitificado sobre o conjunto que procura suas "origens" e não opera no sentido de compreender suas camadas históricas.

I| carattere assiomatico e dimostrativo dell'intero quartiere è rimasto dunque confinato nell'auratico alone della sinopia fotografica: la strada, vale a dire, attraverso cui la contraddittorietà del fenomeno storico è stata pacificata e consegnata immobile al delle stratificazioni non come scrupolo archeologico ma come

Foi realizado um levantamento dos edifícios considerando as partes originais ${ }^{41}$ Do alemäo: "Amigos de Weissenhotsiedlung". 42 Há uma suspeita de que Mies van der Rohe tenha
desaprovado um dos projetos de Rasch e de sel mobiliário porque estava, no mesmo momento,
desentando as suas caderias em balanç (MR-10, em

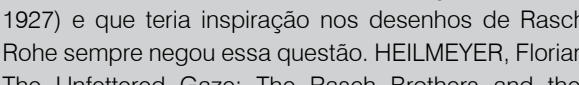
The Unfeterered Gaze: The Rasch Brothers and their

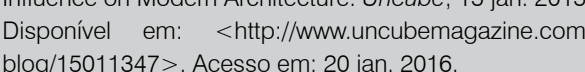
${ }^{43}$ DomUS. n. 649 , p. 2-13, abril de 1984.
Nesse caso, há um conflito de interesses entre os curadores que desejam recuperar um estado original dos edifícios e seus proprietários e usuários que desejam morar em uma casa confortável de acordo com os padrões atuais - que podem, inclusive ser contraditórios com as propostas de projeto originais. Evidentemente, nesse tipo de restauro, cabe uma discussão sobre a habitabilidade de edifícios projetados um século atrás e as demandas contemporâneas. A preservação não deve impedir alterações para atender a questões atuais. Pelo contrário, essas mudanças são essenciais para que as residências continuem ocupadas. A questão principal é saber a justa medida entre preservar os valores e permitir uma ocupação contemporânea.

O princípio que guiou os trabalhos foi o de recuperar um suposto estado original em toda a parte externa do conjunto com a busca das cores originais e apagamento de qualquer marca de passagem do tempo. No interior foram feitas alterações para atender

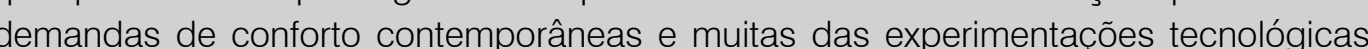
foram perdidas ${ }^{44}$.

[...] il lato più importante del nostro lavoro è cercare di trovare delle soluzioni chi soddisfino tutti questi intendimenti, di tradurli in progetti realizzabili che non tradiscano l'architettura L'involucro di tutti gli edifici viene ripristinato senza compromettere, anche nei colori. Negli interni non è sempre possibile seguire questa nei colori. Negli sndo le case non dei musei ma delle abitazioni regolarmente cedute in affitto. (DOMUS, 1984, p. 5)

que fica evidente nessa proposta é um olhar que separa "interno e externo". Por que não trabalhar com o mesmo critério - da intervenção contemporânea - no conjunto como um todo? Por que não permitir a compreensão da passagem do tempo e da apropriação dos edifícios também no seu exterior?

[...] prendiamo ad esempio il restauro della casa unifamiliare di Le Corbusier: l'esterno, nella forma e nei colori, corrisponde all'originale del '27. I serramenti in acciaio nella zona inferiore e i serramenti scorrevoli in legno nella parte superiore corrispondono nelle dimensioni a quelli del '27; mentre sono stati perfezionati il meccanismo e l'solamento. All'interno sono stati ricostruiti i caratteristici elementi plastici: la scrivania in cemento, armadi a muro in cemento, il bagno aperto con pareti ad altezza parziale. I colori, invece, per desiderio degli inquilini, non sono quelli originali (molto più forti). Gli impianti (riscaldamento, sanitari, ecc.) sono stati totalmente rinnovati, e corrispondono alle esigenze di oggi. (DOMUS, 1984, p. 5) mito. Tra "la messa in posa" dell'ieri e la drammaticità dell'oggi si stende dunque uno spazio del tempo che chiede di essere rappresentato e parlato: riconsegnare il "moderno" al ciclo della "storia delle cose" vuol dunque anche dire riconsiderare il valore indicazione di una sua possibile vitalità problematica. (DOMUS, 1984, p. 5)

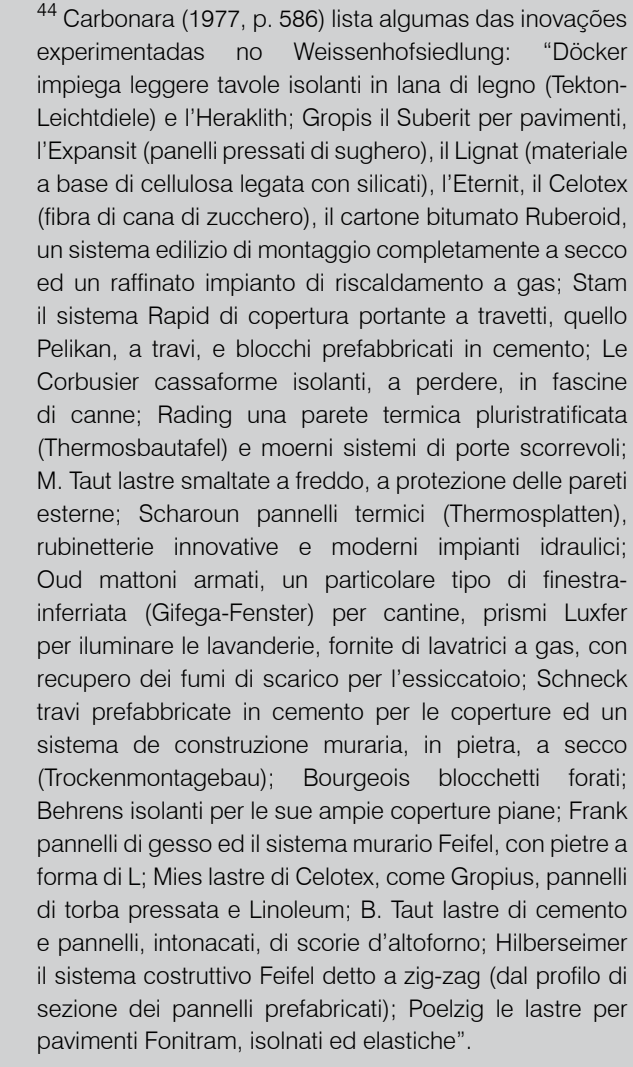
questa storia? (1984, p. 11) 


\section{SIEDLUNG AM WEISSENHOF}

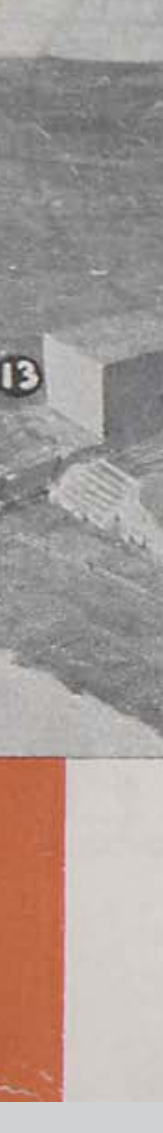

a the

9

Q $\frac{0}{0}$

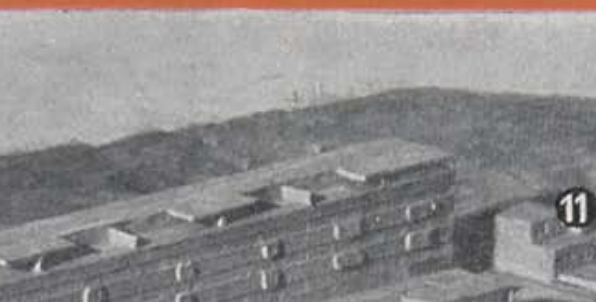

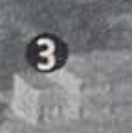

$=0$ 4is 6 का ए 6 ${ }^{1}{ }^{11} \quad 12>1$ 8 $\leqslant 10$ 1. 8

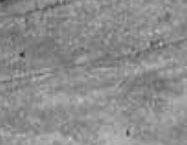
ERSTELLT DURCH DIE STADT STUTTGART NACH. DEN VORSCHLÄGEN DES DEUTSCHEN WERKBUNDES WERKBUND AUSSTELLUNG DIE WOHNUNG JULI-SEPT. 1927 STUTTGART
Projetada em 1927 e construída em 1928 por Gregori Warchavchik (1896-1972), a casa da Rua Santa Cruz é considerada, por alguns autores, a primeira obra moderna do país. Há controvérsias sobre a classificação do prédio como arquitetura moderna, devido a algumas soluções construtivas que buscam mais a imagem dessa arquitetura do que a essência da construção.

Uma das questôes levantadas é o fato de a cobertura ter sido executada com telhas cerâmicas e ser escondida por platibandas, dando a impressão de se tratar de uma cobertura plana. Segundo o próprio arquiteto: "Náo tive coragem de construir a casa com cobertura de terraço-jardim, como teria desejado. Ainda não existiam na praça os materlals isolantes adequados. Cobri o telhado, embutido entre as paredes, com telhas coloniais" (FERRAZ, 1965, p. 51)

Em 1934, a casa passou por uma série de reformas feitas pelo próprio arquiteto com a inserção de uma marquise e a ampliação da sala com a construção de uma laje, configurando um terraço no pavimento superior.

A casa está construída em um terreno de grandes proporções, cujos jardins foram projetados pela esposa do arquiteto, Mina Klabin (1896-1969), em perfeita consonância com o projeto da edificação.

O pedido de tombamento da Casa da Rua Santa Cruz foi feito em 1983 por associação de moradores da vizinhança menos mobilizados por seu valor arquitetônico do que pelo risco da transformação do grande terreno ajardinado em área densamente edificada com torres de apartamento. No processo de luta por sua preservação muitas outras manifestaçōes somaram-se a esta, inclusive as que avaliavam a importância da edificaçáa como "marco da arquiletura moderna paulistana" que foi sua justificativa de tombamento, mas o que dellagrou este processo foi, sem dúvida, a ameaça de destruição. (WOLFF, 1998)

O imóvel passou a ser propriedade do estado em 1994 e, desde então, alguns trabalhos de conservação foram realizados. Sobre a sua recuperação, o arquiteto Marcos Carrilho escreveu que havia três alternativas:
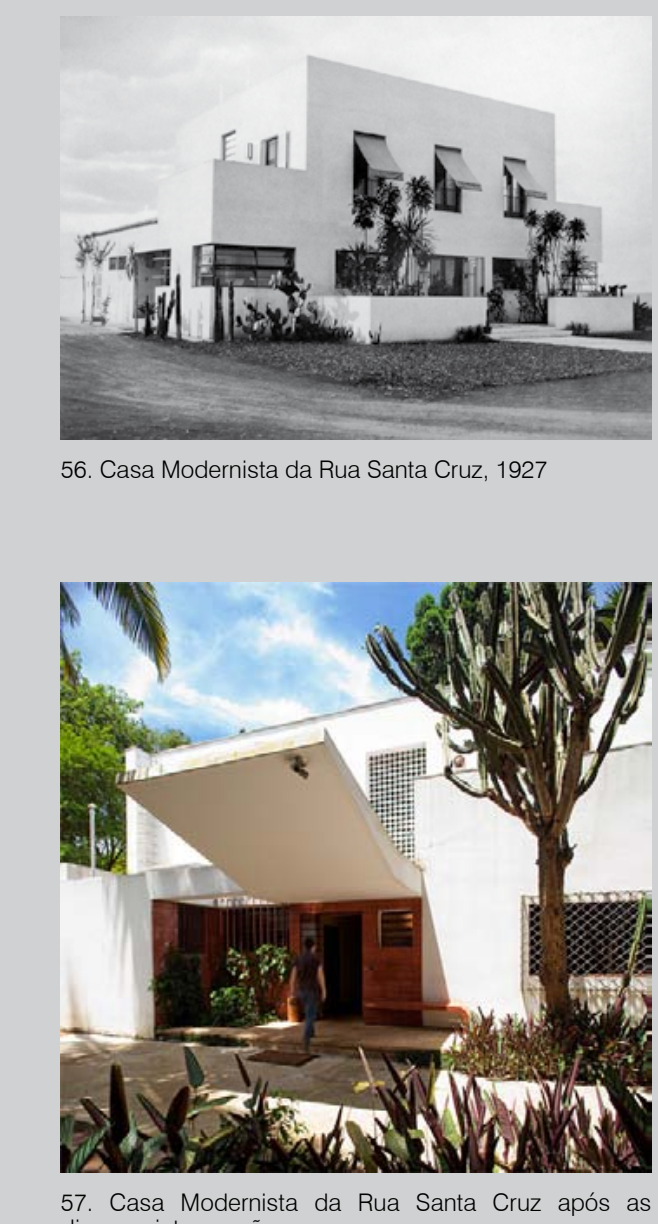

57. Casa Modernista da Rua Santa Cruz após as 
[...]

a) preservá-lo tal como se encontra:

b) recuperar alguns de seus aspectos originais como a fachada emblemática preservando o restante de acordo com a situação atual;

c) fazê-lo retornar à sua configuração original. (CARRILHO, 2000)

O arquiteto descarta as duas primeiras hipóteses e justifica a terceira já que

A reversão da casa à sua configuração original é relativamente fácil. Não se trata de recriação, pois lá estão presentes quase todos os elementos originais. O mais dificili - porem simples diante dos recursos hoje disponiveis - e a remoçáo da laje do terraço. $O$ pavimento superior é pralicamente o mesmo, tendo sofrido apenas alguns acréscimos. A iconografia disponivel e suficiente para orientar a recuperação dos elementos em seus detalhes. dúvidas e confirmar detalhes construtivos. (CARRILHO, 2000)

Evidencia-se a idealização da obra no seu suposto estado original. Uma repristinação que se pauta por imagens e que retira o efeito da passagem do tempo sobre a obra.

Desde 2008, a casa faz parte de um programa municipal chamado Museu da Cidade de São Paulo. Uma rede de edifícios formada por doze exemplares arquitetônicos administrados pelo Departamento do Patrimônio Histórico (DPH) $)^{45}$.

Uma visita à casa deixa evidente que fazer parte desse programa de museus 45 O núcleo conceitual e administrtativo da rede situa-se
no conjunto formado pelo Solar da Marquesa de San-

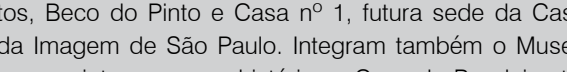
os seguintes espaços históricoss: Casa do Banderiante.
Casa do Sertanista, Capela do Morumbi, Stitio Morrinhos.
Casa do Tatuane, Stiti da Ressaca, Monumento à Inde. Casa do Tatuapé, Sitio da Ressaca, Monumento à Inde
pendência, Casa do Grito e, em 2008, foi agregada a

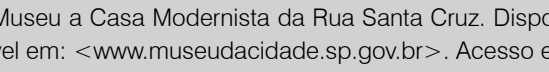
13 fev. 2011.

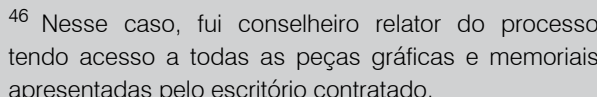
não é suficiente para que se estabeleça um uso adequado e suficientemente intenso evitando a deterioração do imóvel.

Em 2013, foi protocolado no CONDEPHAAT um novo projeto de intervenção no conjunto da casa ${ }^{46}$

No material apresentado pelo escritório contratado pela Prefeitura de São Paulo para desenvolver o projeto observa-se que:

Sobre o uso da edificação o processo, no "Anexo II: diretrizes e programa de Uso" estabelece que a intervenção tem como mote a valorização dos bens existentes, a adequação do conjunto à acessibilidade, a implantação de múltiplos usos para ampliar $e$ diversificar o público usuário do conjunto, a criação de um espaço de referência para estudo do modernismo em São Paulo, tanto pela adoção do conceito da casa modernista como "museu de si mesma", como pela previsão de espaços para debates, palestras e pesquisa, a criação de áreas agradáveis para fruição do parque. (CONDEPHAAT, 2011)

A proposta indica a intenção de "restauro" de todas as construções anexas à casa e a justificativa está, invariavelmente, pautada no fato de serem construçōes de autoria de Warchavchik. Assim, um anexo praticamente arruinado seria construído "conforme o original", por evidenciar um estudo de estrutura que 0 arquiteto supostamente iria experimentar em outras obras. Esta é uma leitura do arquiteto-autor da intervenção que coloca Warchavchik num lugar divino: tudo o que ele pensou e propôs naquele local deve ser considerado patrimônio cultural e portanto, preservado e restaurado. Mesmo que cabível, um pequeno anexo em ruínas ser tratado como "obra de arte" e ser restaurado supostamente com'era dov'era, evidencia uma postura que pouco problematiza as diversas questões envolvidas, como o significado que o estado atual daquela construcãa adquiriu, a documentação lacunosa sobre a construcão a suas transformações, o porquê do abandono, as outras possibilidades que se abrem a partir da ruína, entre outras.

A decisão de recuperar os anexos da casa parte única e exclusivamente da leitura do arquiteto, como uma tentativa de impor sua visão sobre a casa no "corpo" da obra construida, sem um respaldo consistente vindo por parte da historiografia ou deduzido a partir de uma leitura mais acurada do complexo. Corre-se o risco de uma deformaçáo ou revisá historlográfica sem un olhar cillico para aquilo que efelivamente poderia ter valor. Importante lembrar que o principal valor atribuído à casa se dá pelo momento em que foi construída e por sua proposta de vanguarda.

Caberia discutir qual a justificativa para a reconstituição desses anexos, se 0 próprio documento apresentado despreza sua relevância. 


\section{Construção a partir do projeto}

Na segunda metade do século XX, os arquitetos modernos da segunda geração conseguiram fazer uma revisão das obras e posturas dos arquitetos da primeira geração, mas isso, na verdade, foi um novo alinhamento; pode-se dizer, inclusive, que foi uma continuidade ${ }^{47}$. Neste momento, início do século XXI, a leitura crítica deve ser feita de outro lugar: o da preservação. Exige comprometimento com outras questões e não com a continuidade do projeto moderno.

Estudar a documentação existente, atualmente, não deve ser buscar um estado original, retroceder, voltar no tempo. A existência de farto material de pesquisa não autoriza esse tipo de postura. Pelo contrário, a documentação deve amparar o profundo conhecimento, e assim evitar intervenções pouco cuidadosas.

São numerosos os casos em que a existência dos projetos executivos completos (arquitetura, estrutura, instalações etc.) é evocada no sentido de um retorno à imagem e semelhança do que seria o projeto originalmente concebido. A documentação não pode, nem deve ser ignorada. É fonte essencial de informações para a compreensão da arquitetura. A partir dela, pode-se apreender uma grande quantidade de dados que colaboram para os vários valores atribuídos às obras, principalmente no que diz respeito à sua materialidade e imagem. Mas não pode ser tratada como representação fiel das obras a serem executadas, e menos ainda sugerir ser ação de preservação de monumentos históricos.

Há nesse tipo de postura uma contradição que diz respeito inclusive aos valores preconizados pelos modernos. A arquitetura moderna mais propositiva não se apresenta como um estilo, uma imagem. Pelo contrário, propoe, em princípio, atender as demandas e funçoes de una sociedade que se transtormara, que necessitava de um novo modelo de vida na cidade. Essa resposta náo se dá apenas na espacialidade e nas formas propostas, mas tamberm no seu sistema construlivo. Trata-se de compreender que tão importante quanto a imagem é a construção. Os famosos cinco pontos de Le Conbuster, clados anteriomente, versam exatermente sobre questoes construlivas. Assim, intervençoes que visem a se aproximar apenas de uma imagem e que, na busca desse resultado, alterem o sistema construrvo desconsiderando seu valor, caminham num sentido contrário a um dos principais postulados da arquitetura do século XX.

Grande parte dos problemas de preservação da produção moderna diz respeito à grande experimentação de sistemas que foram desenvolvidos. O concreto, o aço o vidro passam a ser utilizados de forma inédita; se por um lado permitem situações jamais pensadas anteriormente, por outro, são responsáveis por grandes problemas na sua conservação Não significa dizer que esses sistemas devam ser simplesmente substituídos, preservando ser repetidos, incorrendo no mesmo problema resultante da experimentação. Trata-se, mais uma vez, de encontrar, a partir do projeto, a justa medida que dialogue com a preexistência no sentido de preservar os valores reconhecidos e viabilizar a conservação e utilização dos edifícios em questão. Há de se ponderar até que ponto a preservação de uma imagem intacta é a melhor forma de intervenção. Se a "forma segue a função", as intervenções contemporâneas devem utilizar a tecnologia atual em seu melhor desempenho o que seguramente, levaria a formas diferentes. Esta é a criatividade que Reichlin propõe nos projetos: a necessidade de conciliar a preexistência com as novas demandas a partir de bons projetos contemporâneos.

Qualquer intervenção, num bem ou num contexto de interesse histórico, implica mudanças, mas isso não deve significar cancelar fatos históricos e estéticos de interesse para naquele espaço, sobrescrever uma nova história, por melhor que seja essa "nova história". A ação contemporânea deve se colocar como novo estrato, aposição, justaposição, integração e jamais como eliminação ou substituição de documentos históricos, para forçar uma nova realidade totalmente diversa daquilo que lá existe. É necessário, através do projeto, inserir nova estratificação que se comporte como adição que não destrói o edifício ou o coniunto urbano, nem do ponto de vis figurativo. (KÜHL, 2006, p. 30)

Mas estaé, também, a maior dificuldade ao se tratar da preservação do moderno. Decidir o que preservar, como substituir ou como intervir para adequar o desempenh sem perder os valores reconhecidos. Considerar ainda que grande parte dos materiais utilizados continuam em produção, ou evoluíram do ponto de vista tecnológico, demanda cuidado extremo para todas as decisões.

Volta-se mais uma vez ao tema do discurso dos autores ou de seus herdeiros. Em diversas situaçōes, falas realizadas no âmbito privado (em reuniões de trabalho, em casa etc.) são trazidas para justificar as ações e as intenções no projeto. Vale reafirmar que tais informações não devem ser negligenciadas, mas não podem pautar, exclusivamente, as discussões.

No entanto, não são apenas essas pessoas que assumem essa postura. Estudiosos de arquitetura e órgãos de preservação também costumam atuar com o propósito de recuperar uma suposta originalidade dos grandes autores e de suas obras, em um argumento defensivo que supostamente garante sua preservação, afastando-as de intervenções danosas e descuidadas. 
Se há consenso de que a melhor forma de preservação de um edifício é a sua utilizaçãa, há de se entender que as suas formas de apropriação, em que pese a manutenção do seu uso, se modificam substancialmente ao longo do tempo. Demandas acessibilidade universal precisam, na medida do possível, ser atendidas da forma mais apropriada. A nostalgia e a consequente impossibilidade de intervenção de um edifício pode ser um fator determinante para inviabilizar sua preservação. Conforme Bardeschi (In CARBONARA, 1997, p. 362): "[...] di cositenza fisica si perde in un'architettura è perduto per sempre. Non c'è alcuna possibile arte magica che possa alimentare la ingenua nostalgia . di richiamare in vita le componenti perdute del nostro passato".

A mitificação dos autores modernos coloca outra questão que, com o passar pempos, vem se tomando recorrentei exis projetos feitos por vários arquitetos já falecidos e que jamais foram construídos.

Outros projetos, devidamente construídos, e documentados também com fotos da construção, foram, por numerosas razões, demolidos.

Além da ação do DOCOMOMO de documentação do moderno, diversas outras instituições têm ampliado seu acervo e disponibilizado-o publicamente. O MoMA (Muse of Modern Art, em Nova York) oferece em seu site uma grande quantidade de projetos; a FAU-USP tem um importante aceno de arquitetos do seculo XX. Alem deles, acervos particulares foram organizados em fundaçōes que levam os nomes de seus autores ${ }^{48}$.

O estudo desses documentos tem se mostrado de extrema importância para a compreensão de processos, de ideias que se desenvolveram em outras obras, e de percursos. Essenciais, portanto, para o aprofundamento do conhecimento sobre os autores e também como referência para novos projetos. São parte primordial da produção da arquitetura moderna e sua organização em diversos acervos é uma contribuição inquestionável para o ensino e prática da arquitetura. mas há de se compreender qual o seu real papel.

O que se tem visto é a utilização desses documentos como base para a construção de obras novas, que tem sido divilgad autoria dos principais arquitetos modernos. São?

O incessante esforço de encontrar projetos de autores consagrados e ainda a possibilidade de que esses autores continuem projetando mesmo após a sua morte, seja a partir da permanência de seus escritórios, de croquis de estudo, ou até de projetos desenvolvidos e jamais construídos, remete à questão da valorizacão econômica do patrimônio discutida anteriormente. São muitas vezes estudos que não foram concebidos para ser construídos. Desenhos de discussão, de abordagem e de partidos que podem, seguramente, contribuir para a compreensäo de processos e para o reconhecimento de valor.
A construção desses edifícios segundo a suposição do que teria sido a proposta do projeto ou uma copia fiel de um edificio demolido e bastante questionável. O que justifica construir um edifício pensado tantos anos antes?

Se aceitarmos que a única possibilidade de produção da arquiteturaé a do tempo presente, construir um edifício que foi concebido seguindo programas, tecnologias e demandas de um tempo anterior é de um anacronismo inadmissivel em diversos aspectos, tanto do ponto do vista das propostas de vanguarca da arquitetura moderna, como do ponto de vista do que é a preservação e do que é a produção contemporânea de arquitetura

Os documentos utilizados como base para esse tipo de ação para novas construçōes - projetos, croquis, perspectivas, maquetes - são, inevitavelmente, alterados em função de diversas questôes contemporâneas. Os cálculos estruturais, a resistência dos materiais, as tecnologias de construção evoluíram e têm hoje condições de melhor desempenho. As demandas de segurança e acessibilidade são outras, mais restritivas em relação ao período em que o projeto foi concebido. Em alguns casos, nem mesmo o programa original é possível. Todas essas questões interferem na nova construção evidenciando a impossibilidade de um processo de reconstrução com o intuito de reaver edifícios em seu suposto estado original. Há, na melhor das hipóteses, uma aproximacão da sua imagem idealizada É nesse sentido que não cabe, para a discussão colocada neste trabalho, o termo "reconstrução".

Além disso, é necessário compreender a relevância do entorno na concepção e na implantação de um edifício, que, principalmente se tratando de área urbana seguramente leve alleções do momento da concepção do projeto até a decisão de construí-lo.

Portanto, são intervenções de diversas ordens que ficam sempre submetidas a uma imagem ideal que se pretende atingir.

Mas se entendermos que parte substancial da arquitetura está nesses aspectos e que uma das máximas modernas - não a considerando uma verdade absoluta sempre foi "a forma segue a função" "ị", não há um equivoco fundamental na decisão de construir uma o demandas e possibilidades tecnológicas diversas?

O resultado plástico dos edifícios está intimamente relacionado com os aspectos colocados anteriormente. Ás questões contemporâneas impõe-se uma nova imagem, relacionada diretamente com seu desempenho e seu sistema construtivo. A estrutura de um edifício pasa a ter protagonismo interferindo substancialmente na imagem das obras. Se o moderno propunha um rompimento violento com a arquitetura historicizada eclética por considerá-la anacrônica, principalmente pelo uso de ornamentos acabamentos supérfluos, parece que buscar a imagem de um edifício moderno como 
forma de sua preservação é a negação de um dos principais dogmas daquilo que se quer preservar.

Além disso, pressupor que um arquiteto, sejaele quemfor, daria a mesmaresposta projetual hoje a um problema colocado décadas atrás significa congelar o pensamento desse autor no tempo, tratá-lo como reliquila. Essa é uma questão fundamental para se abordar a preservação, e que precisa ser reafirmada constantemente. 0 campo da preservaçáo se diferencla do da história. A leitura critica que se propōe náo é feita no sentido de elaborar ou reescrever a historiografia, mas de atribuir e trabalhar com valores reconhecidos hoje como bem culural, com o propósito de sua apropilaçáa no presente e transmissăo para o fuluro. Assim, hão se pode fosse atual, nem trabalhar com suposições daquilo que um autor estaria pensando caso estivesse vivo.

A la différence d'un patrimoine aux titres d'ancienneté reconnus, le contemporain apparaît pour ce qu'il est en effet: une préfabrication. II s'agit d'une fabrication reflétant l'état mouvant des connaissances in statu nascendi provisoires et souvent divergentes de la critique et de Thistoriographie. Un sentiment inconfortable d'êphémère et d'improvisation se dégage des discours faits autours de la promotion de l'objet en monument. Discours généreux certes, mais souvent creux avec des arguments dun autre temps, mais qu'on retient, parce que si le bâtiment en question est en rupture avec le patrimoine accredite, comment peut-on convaincre de concepts en sa faveur sont inattendus. (REICHLIN, 1998, p. 3 )

O recorte feito aqui pretende, principalmente, discutir se essas obras são de fato autoria dos arquitetos que as conceberam anos antes e patrimônio moderno. Responder à primeira pergunta pode eliminar a segunda.

A perspectiva de encará-las como obras de autoria desses arquitetos abre a possibilidade de construção de numerosos projetos engavetados de grandes arquitetos, com alterações que, de fato, são necessárias. Como faremos então para contar a história da arquitetura moderna? Os principais livros sobre o tema encerraram esse capítulo, cada qual em um determinado momento histórico. Seria então o epílogo que faltava?

Nesses casos, é muito comum que o processo seja conduzido pelos "herdeiros" que, supostamente, saberiam exatamente quais as questôes principais do projeto poderiam então dar continuidade à construçãao.
Atribuir essas obras construídas ao autor dos desenhos originais leva a uma leitura absolutamente equivocada, não apenas da intenção do projeto, da sua materialidade, imagem e espacialidade, mas também cria confusão para compreender o que seria a produção de cada um. Pode uma obra dessas entrar no conjunto de obras completas desses autores?

Parece irresponsável supor que seja possível saber como um arquiteto se debruçaria sobre um projeto de sua autoria anos depois. Não apenas em arquitetura, mas em qualquer outro processo criativo. É Impossivel presumir qual seria a abordagem de um autor sobre sua propria obra alguns anos mais tarde, bem como traçar uma linha evolutiva, que leve a uma solução obbvia. Basta olhar os percursos e obras desses autores para perceber que não se trata de linhas evolutivas previsiveis. Pelo contrário, há mudanças de percurso que, além de surpreendentes, são aquelas que imputam valor ao autor e sua obra. A capacidade de revisão de novos percursos é extremamente instigante e, por mais que se estudem esses processos, qualquer tentativa de supor o que seria a sua continuidade não se sustenta à luz de uma análise acurada.

Portanto, para qualquer obra construída hoje, com a aparência ou a referência a um projeto concebido anos atrás, corre-se o grande risco de contaminar de forma negativa a compreensão do trabalho desse autor no seu tempo. Bruno Reichlin, ao tratar do tema, é bastante firme em sua posição, afirmando que

[...] compléter l'œurre d'un architecte qui s'est battu sa vie durant pour construire utile et contre tout esthétisme académique, avec la seule motivation esthético-commémorative et sans aucune nécessité, constitue vraiment un renversement curieux et détourant des priorités. (REICHLIN, 1998, p. 4)

Os casos a seguir demonstram como as decisões de projeto podem levar a situações que comprometem a compreensão das obras e de seus tempos. 
O Teatro Cultura Artística, projetado em 1942 pelo arquiteto Rino Levi, foi, desde sua inauguração, um dos mais importantes teatros de São Paulo, com programação
nacional e internacional de música e teatro. No livro publicado em 2001, que apresenta as obras do arquiteto, o teatro é descrito da seguinte forma:

Até hoje uma das melhores salas de concerto de São Paulo, o Cultura Artística ocupa quase integralmente um lote de formato irregular no centro da cidade. A elevar a plateia principal do solo, Levi libera uma grande área para o hall de acesso e uma segunda sala para espetáculos menores. Aproveitando o desnível da parte superior da plateia, o foyer, no primeiro pavimento, torna-se um posto de observação da cidade por sobre os sobrados da vizinhança. A sala principal de espetáculos desenvolve o tema das paredes, pisos e teto em curvatura paraboloide, com o objetivo de uma melhor difusão de som. A falta de uma cadeira compatível com a modernidade do teatro levou ao desenvolvimento de um projeto especial, com assento e encosto móvel. A grande parede dos fundos da sala de projeçōes, que desenvolve uma suave curva ao acompanhar a forma do terreno, recebe um gigantesco painel de Di Cavalcanti, levando à paisagem urbana o tema das musas das artes. (LEVI, 2001, p. 148)

O edifício teve sua sala de espetáculos completamente destruída após um incêndio, em 2008 . Apenas o painel artístico de Di Cavalcantí, que com e uma área do foyer resistiram ao fogo. A estrutura da cobertura, de madeira, desabou. Nas discussōes sobre como proceder nesse caso, as virtudes técnicas da sala foram enaltecidas e a existência do projeto executivo senviu como argumento para a tentativa de reconstrução do edifício De acordo com a reportagem do jornal Folha de S.Paulo (texto na página 110), um dia após o incêndio, os arquitetos consultados p pronunciaram a favor da reconstrução do projeto de Levi, "com algumas adaptações para condições mais contemporâneas". Chama atenção o fato de que os três arquitetos tiveram forte ligação com Rino Levi e o próprio texto da matéria os coloca como "[...] [Machado e Anelli,] dois dos maiores estudiosos brasileiros da criação de Levi, com livros e teses publicados". Esse tipo de abordagem, se mal interpretada, pode levar a compreensão de que se está sugerindo a reconstrução conforme o projeto original.

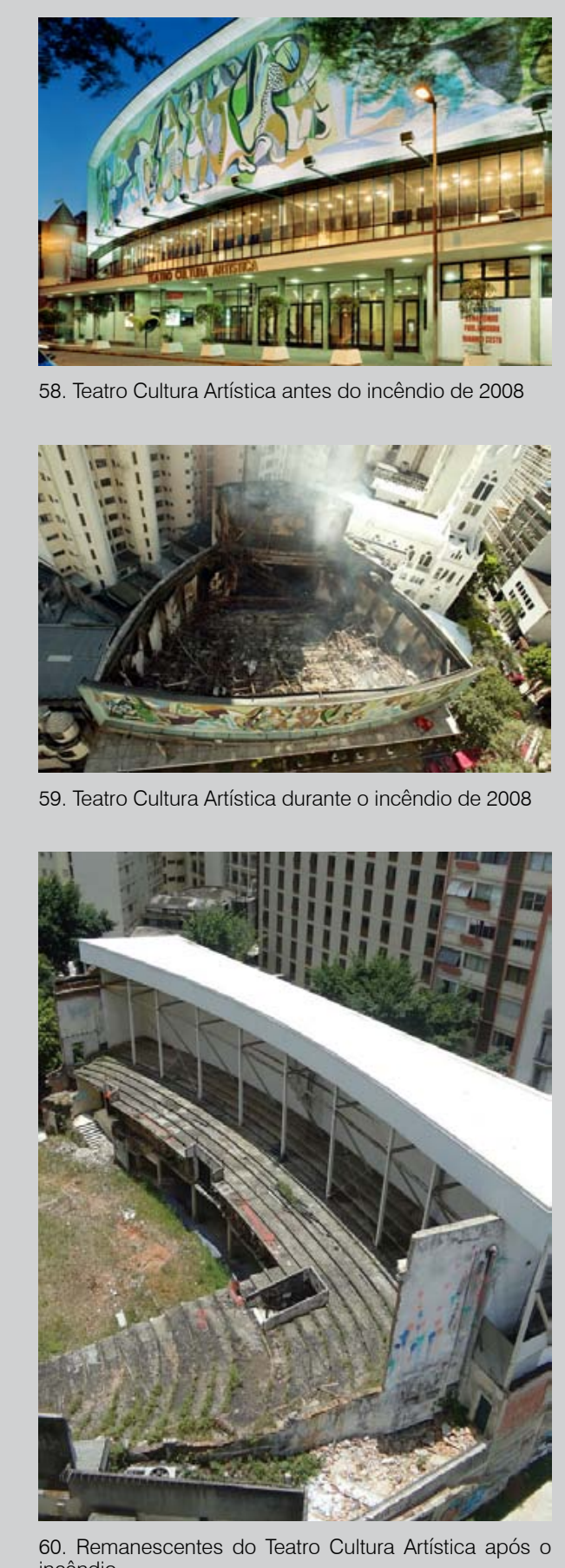


Texto da matéria:
Arquitetos defendem reconstruçăo do projeto de Rino

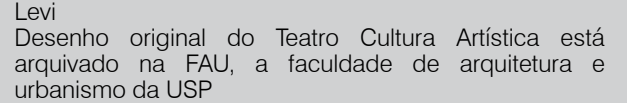

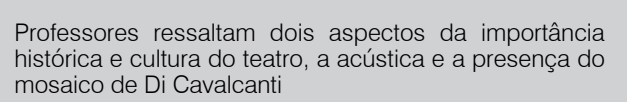

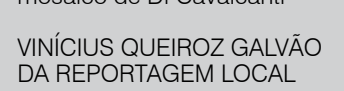

Projetado por Rino Levi, o teatro Cultura Artística,
destruido num inceindio de causa ainda desconhecide de especialistas no legado da obra do expoentile e un

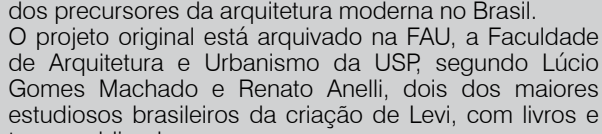

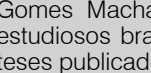

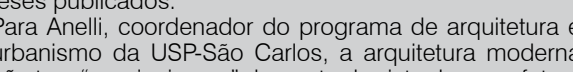

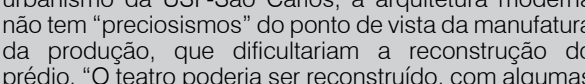

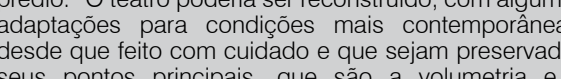

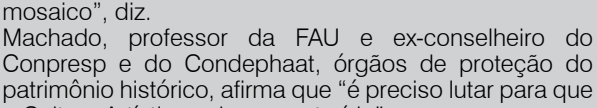

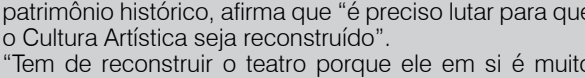

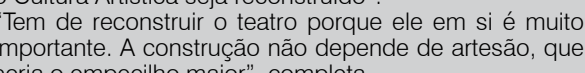

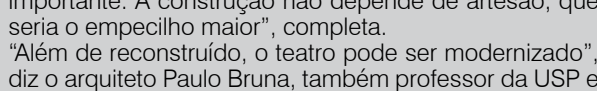

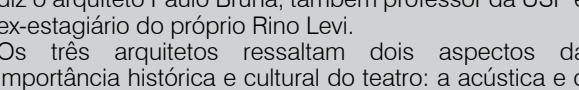

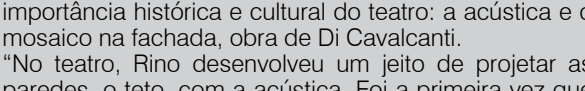

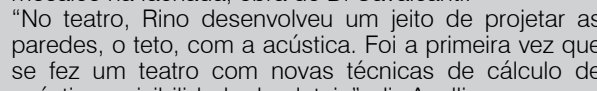

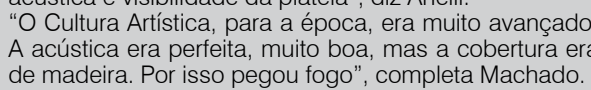

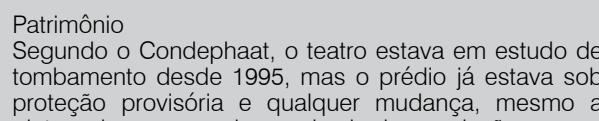

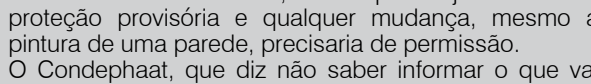

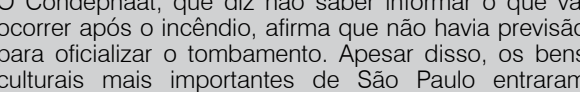

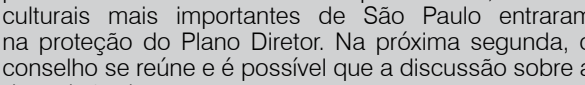

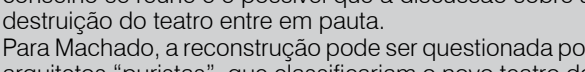

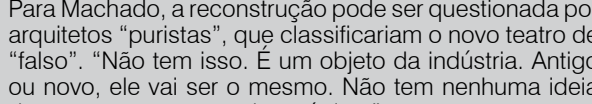

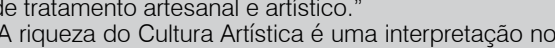

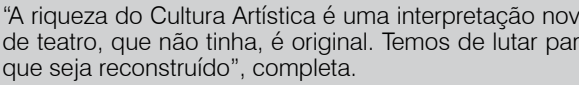

Por melhores que fossem as soluções técnicas do projeto, passados mais desenvolvidos e devem ser utilizados - tanto em relação às questões cênicas e acústicas, como às de segurança.

Um novo teatro está sendo projetado pelo arquiteto Paulo Bruna, que trabalhou com Rino Levi. O painel passou por um processo de restauro e o novo edifício, apesa de estar no mesmo local e preservar parte da estrutura que sobreviveu ao incêndio, absolutamente novo.

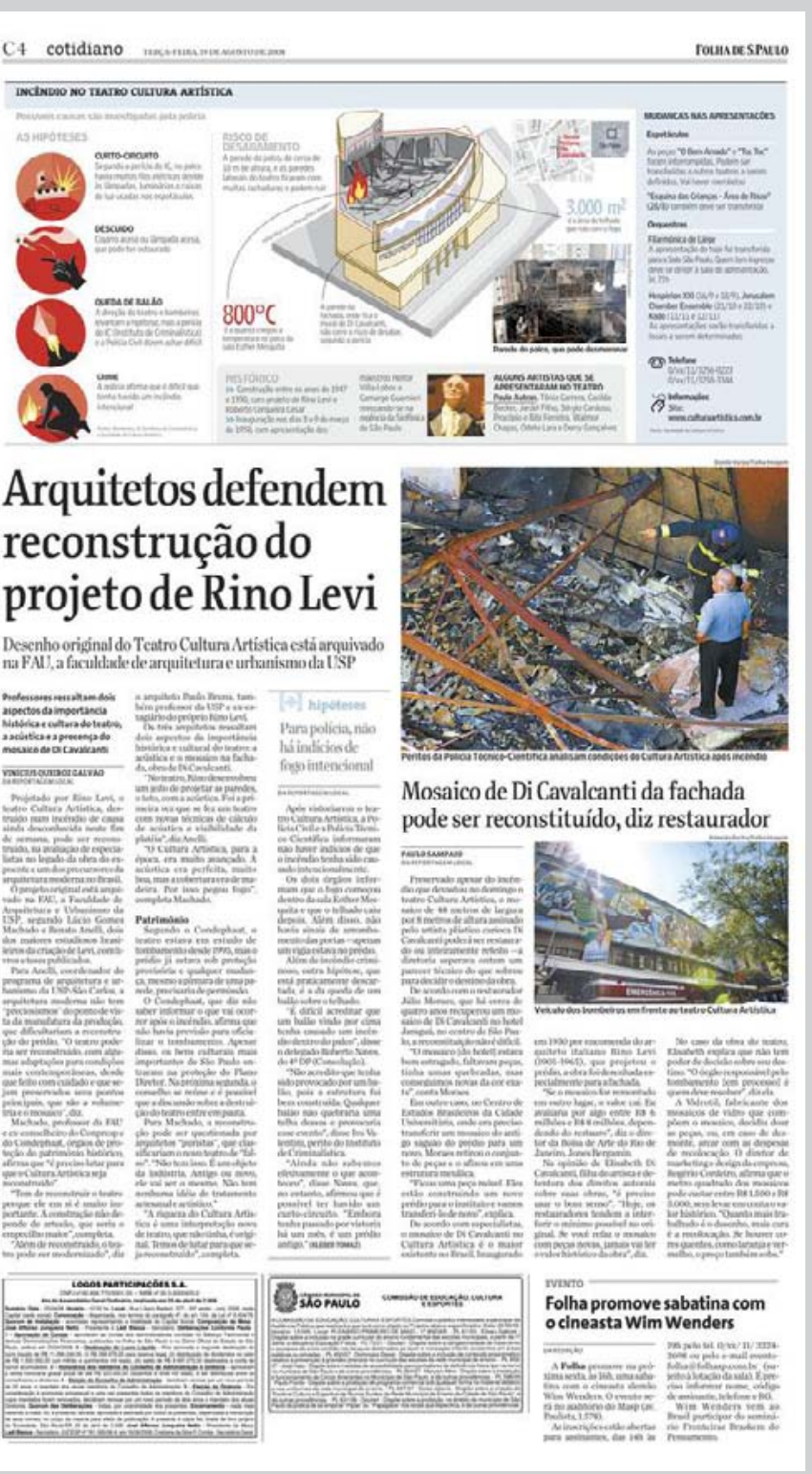

\section{Igreja de São Pedro de Firminy - Le Corbusier}

Firminy, uma pequena cidade da região do Loire, na França, nos anos 1950, eve em sua proposta de expansäo urbana um projeto denominado Firminy Vert ${ }^{00}$ Nessa área estava prevista a construção de um centro cultural e esportivo, uma unidade de habitação e uma igreja. Le Corbusier foi contratado para desenvolver o projeto do novo centro esportivo e do centro cultural. Nos anos 1960, projetaria a unidade de habitação e a igreja ${ }^{51}$.

No ano da morte de Le Corbusier, em 1965, parte do centro estava em construção, e alguns edifícios, como a igreja, ainda não haviam sido construídos. Em função de diversas questões políticas e econômicas, a igreja teria suas obras iniciadas apenas no inicio dos anos 1970. No final da década, apenas os dois níveis de embasamento haviam sido construidos e a obra foi interrompida. Abandonado, nos anos 1980 o edifícic estava em pessimo estado de conservação: "Ruina e edificio inacabado ao mesmo

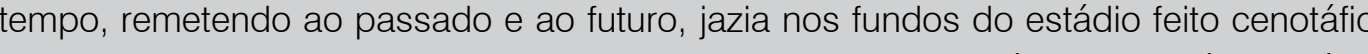
de seu chiador e testasa da vanguarda" (PELEGRINI, 2008, p. 217).

Com a interrupção da construção, a base construída foi destinada a anexo do Museu de Arte Moderna.

Segundo Reichlin (1998, p. 4):

[...] si l'on tient compte des toutes les décisions nécessaires à prendre pour répondre aux nouvelles normes de sécurité, aux question de l'équilibre thermique, aux choix des matériaux, l'œuvre ainsi terminee appartiendratt à un autre auteur que Le Corbusier " parce que, dans ce cas, le "monument" est justement, l'œuvre

Nos anos 2000, em um processo de valorização do patrimônio de Le Corbusier em Firminy o arquiteto francês José Oubrerie, que havia trabalhado com ele, desenvolve o projeto do edifício da igreja. Nessa retomada, seu programa original é alterado. Deixa de ser uma igreja para ser um espaço de exposiçōes. A geometria e os materiais também sofrem mudanças no desenvolvimento do projeto, atendendo a novas demandas de segurança e incorporando novos materiais, com novas tecnologias. Entretanto, o novo projeto, que foi claramente inspirado nos desenhos de Le Corbusier, tem seu desenho final com diferenças significativas em relação aos desenhos dos anos 1960.

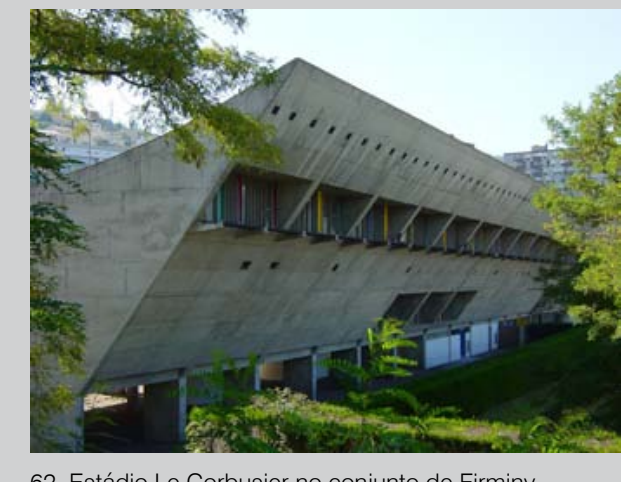

(3an:

63. Embasamento da I Ireja de São Pedro, projeto de Le
Corbusier, em Firminy

A Aclade tinha sua atividade e econônmica diretamente

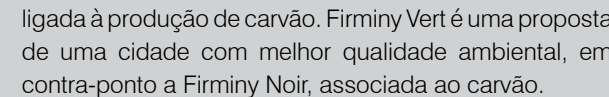
51 Para ver os projetos propostos por Le Corbusier para
Firminy ver os volumes 7 (1957-1965) e 8 (1965-1969)
deil 5 co de $L$ Le
(1995) 


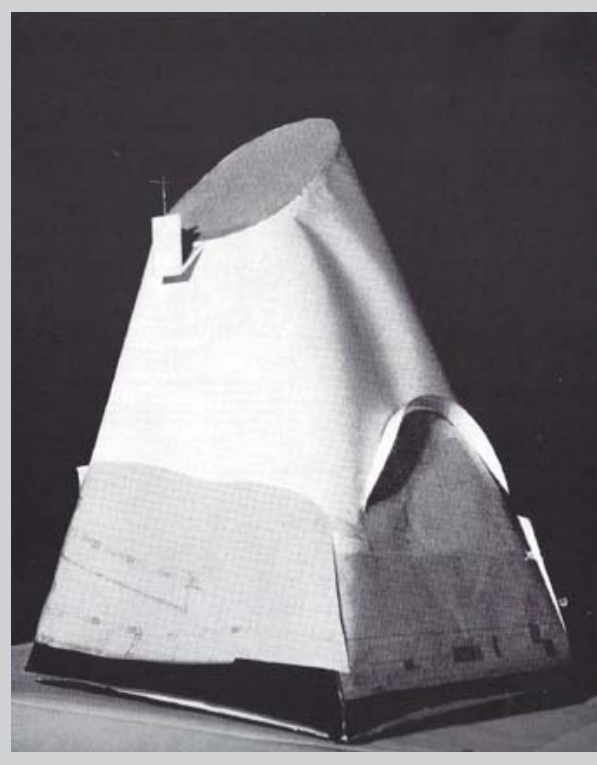

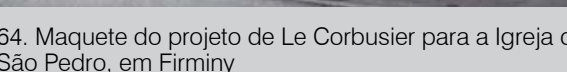

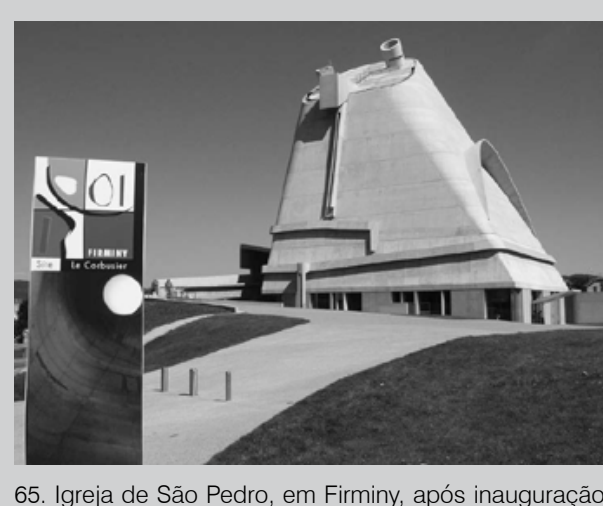

65. Igreia de Sâa Pedro, em Firminy, após inauguraçaco
nos anos 2000
Intervir nesse edifício inacabado não pode ser considerado um desrespeito ou usurpaçáa. Pelo contrário, caberia ao arquiteto-autor da nova intervençáo compreender como estabelecer um diálogo respeitoso com a preexistência, mas que se manifesta como um ato do presente. A construção do edifício, segundo a suposição do que teria sido a proposta original, é de uma submissão inadmissível, tanto do ponto de vista das propostas de vanguarda da arquitetura moderna, como do que é a preservação segundo o que vem refletindo o campo disciplinar do restauro. Ao atuar dessa forma o que se recupera é um ideário de que esta arquitetura é atemporal e não envelheceria jamais. Esse tipo de idealizacão é, na verdade, de cunho positivista e prevaleceu nas intervenções do século XIX. Será que devemos tratar a arquitetura de vanguarda do século XX a partir de um ideário oitocentista superado do ponto de vista crítico e historiográfico?

Supor que seria possível saber como Le Corbusier se debrucaria sobre um projeto de mais de cinquenta anos é não reconhecer a trajetória do arquiteto e as mudanças radicais que aconteceram na sua forma de pro os seus desenhos para Fiminy como uma base para o desenvolvimento do projeto, se não for considerado plágio, no mínimo interfere na percepção da obra do arquiteto de forma negativa, ao permitir que outra pessoa projete em seu nome.

Nesse caso, não se pode dizer que o projeto de Le Corbusier é uma referência, ou que há um diálogo entre a preexistência e a intervençāo contemporânea. Trata-se da reforma e do desenvolvimento de um projeto que não fora executado.

A concepção de Le Corbusier, nos anos 1950, considerava as questões daquele momento, os materiais disponiveis, com suas limitações. Trabalhar no das condiçoes tecnológicas sempre foi uma questao impolante para ele. Reproduzi formas do passado com tecnologlas mais modernas e de melhor desempenho, tira grande parte do valor do projeto.

A mudança de uso é bem-vinda quando a função original já não faz mais sentido para a sociedade contemporânea. É uma das formas mais efetivas de preservação e conservação de um edifício. Se um uso não tem mais sentido para a sociedade, a alteração de atividade é a principal ação no sentido de sua presenvação. Isso não compromete, em hipótese alguma, os valores reconhecidos no edifício, pelo contrário. Portanto, nesse caso, o embasamento executado conforme o projeto de Le Corbusier não tem menor valor por ter seu uso alterado.

Conforme citado anteriormente, não se considera qualquer ordem hierárquica na atribuição do patrimônio cultural em relação à sua ancianidade, seu valor ou pertencimento a um ou outro movimento artístico. Posto isso, pode-se fazer uma comparação entre projetos de intervenção em patrimônio cultural de diferentes momentos históricos, todos com características semelhantes e realizados nas últimas décadas.

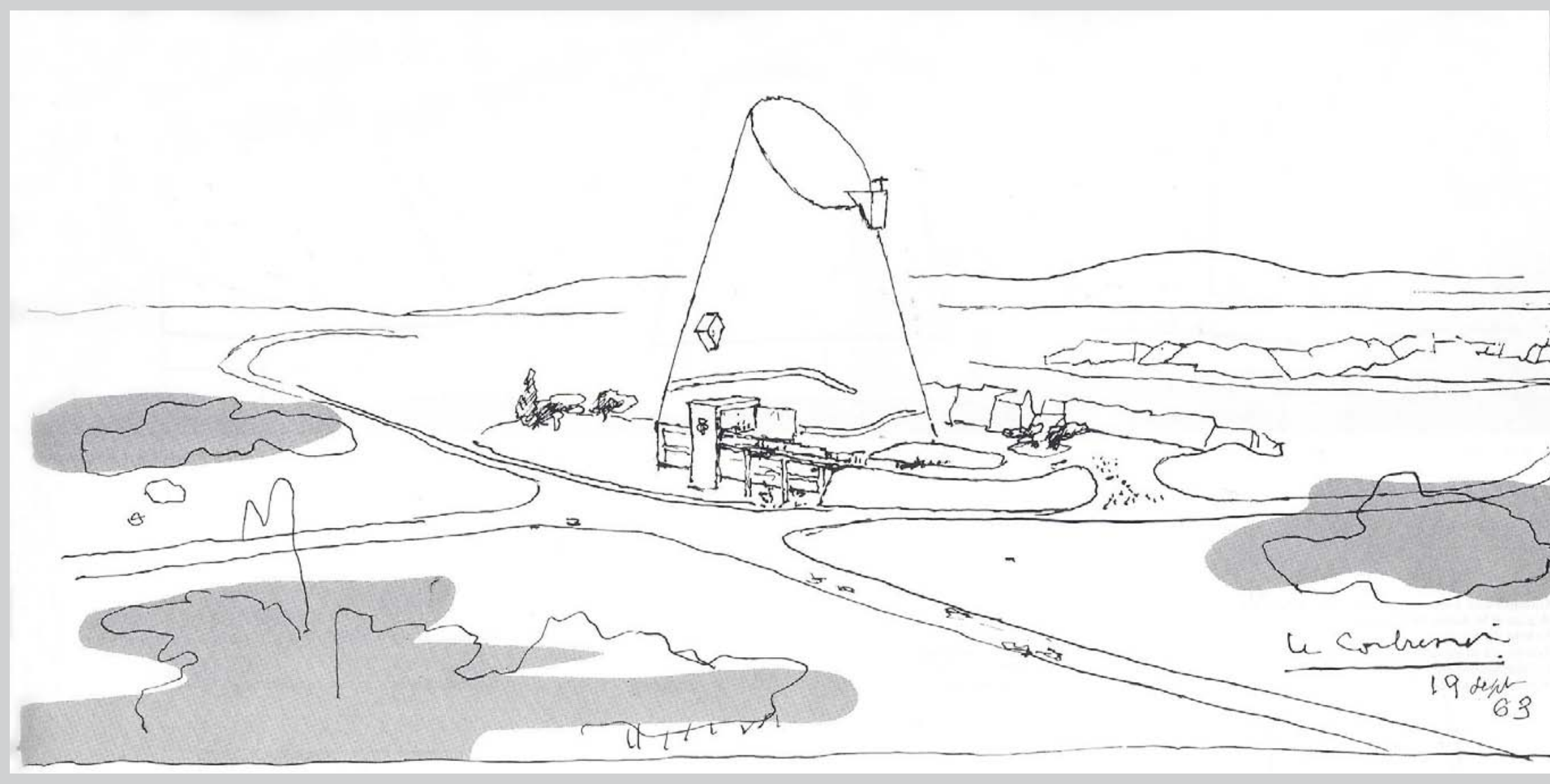




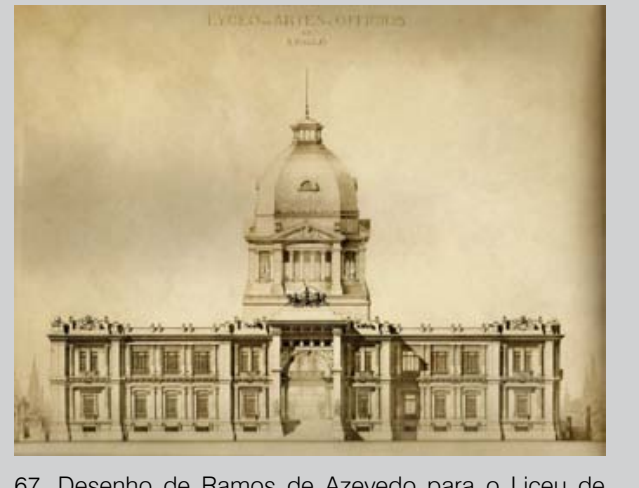

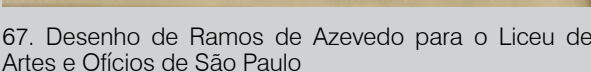

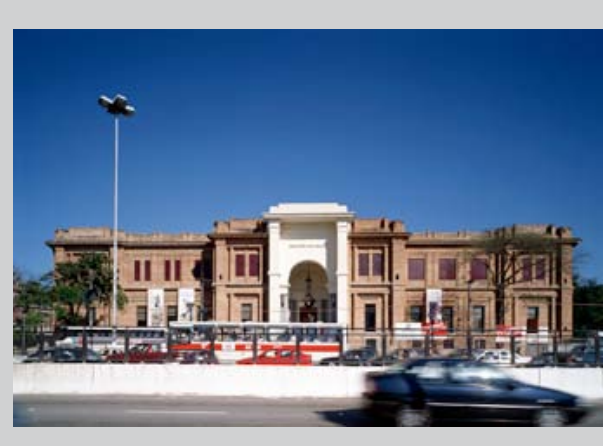

68. Pinacoteca do Estado de
de Paulo Mendes da Rocha
O edifício do Liceu de Artes e Oficios, em São Paulo, tem seu projeto e construção datados dos anos 1890, com autoria de Ramos de Azevedo (1851-1928) - um dos principais nomes da arquitetura eclética na cidade de São Paulo ${ }^{52}$. O projeto original do edifício previa uma grande cúpula apoiada nas alvenarias que configuram o seu espaço central e que nunca foi construída.

Nos anos 1990, o edifício já abrigava a Pinacoteca do Estado de São Paulo e os arquitetos Paulo Mendes da Rocha e Eduardo Argenton Colonelli foram contratados para desenvolver o projeto de restauro e adequaçao do espaço. O projeto, premiado e aclamado, propunha uma cobertura plana construida a partir de uma greha melálica e vidro no mesmo local da cúpula proposta por Ramos de Azevedo. Não há registros de manifestaçóes que reivindcassem a execuçáo da cúpula projelada originalmente. diretrizes para a preservação do edifício.

Reichstag

O edifício do Reichstag foi construído em Berlim nos anos 1880, projetado pelo arquiteto Paul Wallot (1841-1912) para ser sede do parlamento alemão. O edifício pelo arquiteto Paul Wallot (1841-1912) para ser sede do parlamento alemão. O edifício
construído tinha uma cúpula de aço e vidro no seu corpo central. Durante a Segunda construldo tinha uma cúpula de aço e vidro no seu conpo central. Durante a Segunda Guerra foi bombardeado, transtormando-se em ruina. A estrutura da cúpula ainda er visivel, mas estava absolutamente destruída.

Nos anos 1960, o edifício foi restaurado com critérios questionáveis. Não há registros da rúna que se tornou e os trabalhos foram feitos no sentido de recuperar o edifício com'era, dov'era. Nesse momento, sua cúpula não foi construída. Com a reunificação alemã e a volta do governo para a cidade de Berlim, o edifício volta a ser sede do parlamento, nos anos 1990. Logo em seguida, o escritório Foster and Partners é contratado para desenvolver um projeto de intervenção. Além de algumas ações no interior do edifício, projeta-se uma nova cúpula que em nada se assemelha à original. Mais uma vez, o projeto é reconhecido pela sua qualidade técnica e pela sua relação com o edifício. Não se lê, nos textos que abordam esse projeto, um questionamento em relação à nova cúpula. aceita com tanta naturalidade e, no caso dos modernos, essa mesma postura é evitada? O que leva à decisão de construir um projeto à imagem e semelhança daquilo que Le Corbusier pensou cinquenta anos antes? Evidentemente, existem as questões da valorização econômica a partir da obra de Le Corbusier, mas também há a já citada crise de produção de arquitetura que, como mostra esse caso, ainda tem extrema dificuldade moderno

Firminy já tinha em seu território uma unidade de habitação de Le Corbusier e o centro para jovens, mas não era suficiente para colocar a pequena cidade no circuito de

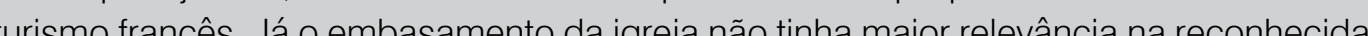
obra de seu arquiteto-autor. Passa a ter após esse completamento questionável.

Hoje, o conjunto que inclui a obra de 2007, faz parte de uma propostatransnacional de reconhecimento pela Unesco chamada L'œuure Architecturale et Urbaine de Le Corbusier $r^{53}$ e está sendo considerado o maior conjunto de obras construídas de Le Corbusier na França Não por acaso, a cidade tem seu escritório central de turismo em um dos edifícios do conjunto. O número de visitantes, que dobrou depois da construção de 2007, revela a importância econômica de açôs como essa.

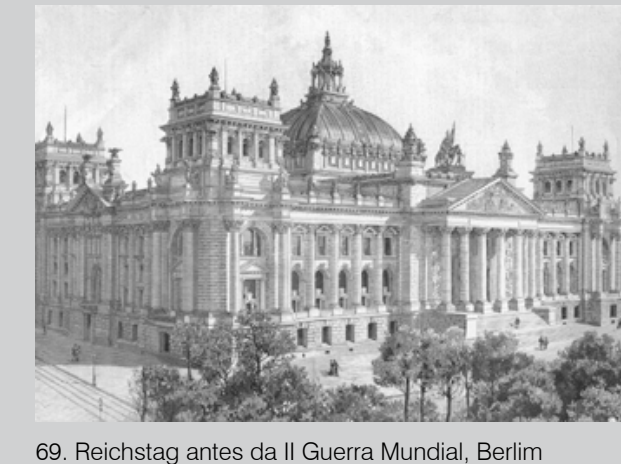

69. Reichstag antes da II Guerra Mundial, Berlim

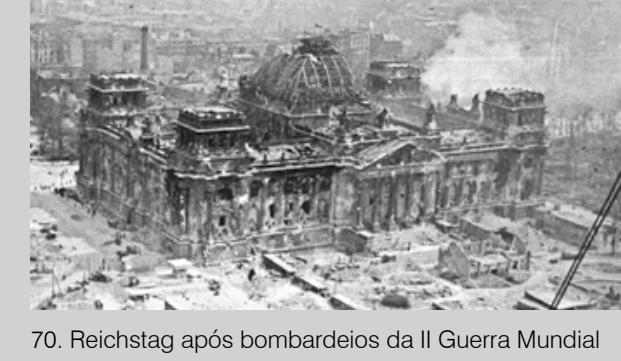

70. Reichstag apos bombardeios dall Guerra Mundial

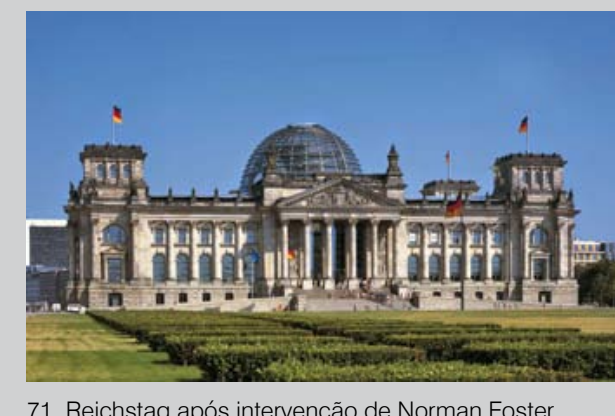

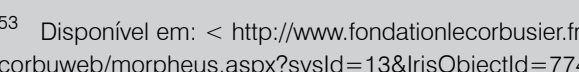

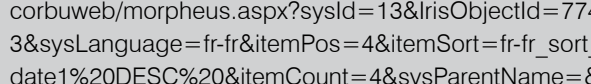

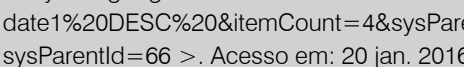




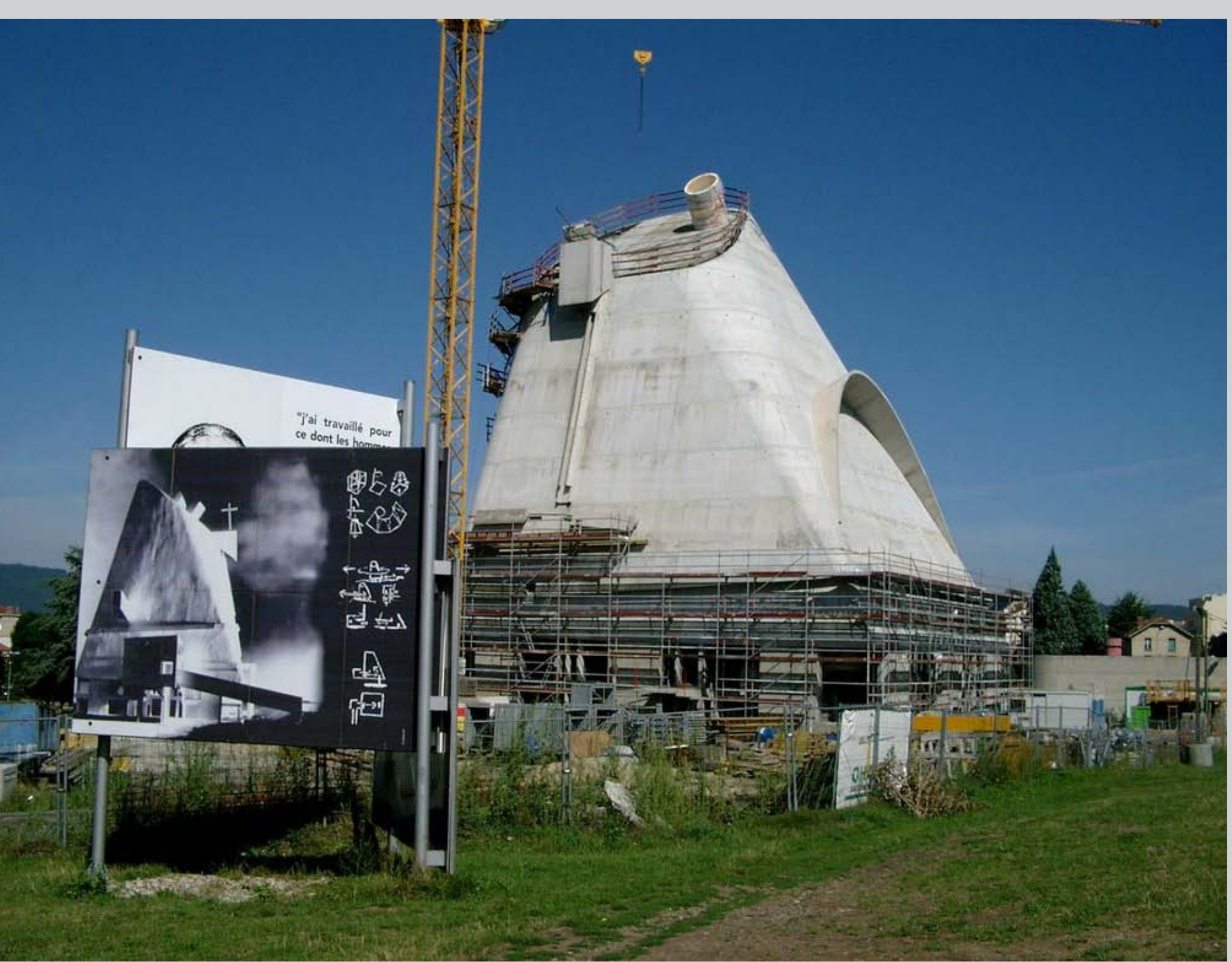

72. Igreja de Săo Pedro em obras, em Firminy. Projetto de José Oubrere
Projetado pelo arquiteto alemão Mies van der Rohe, para a Exposição Universal de Barcelona, em 1929, transformou-se em um dos edifícios ícones da arquitetura moderna pela sua planta inovadora, o uso dos materiais, as transparências e a fluidez do espaço. Estabelecia uma nova linguagem entre os edifícios neoclássicos ao seu redor. Foi demolido logo após a mostra, como já era previsto. O grande destaque dado a essa obra na história da arquitetura moderna foi um dos argumentos para uma nova construção nos anos 1980

No final dos anos 1950, um grupo de jovens arquitetos procurou Mies van der Rohe para propor a reconstrução do Pavilhão. Nesse momento, o arquiteto afirmou que a perda dos desenhos durante a Segunda Guerra não seria um problema. Ele teria condiçoes de refaze-los de memória. Entretanto, nada foi feito até os anos 1980, quando se resolveu ir adlante com o novo projeto de construçao com nado pelo arquilteto espanhol Ignasi de Solà Morales. A obra foi finalizada em 1986

Segundo Solà Morales, essa obra tinha o caráter de reinterpretação do pavilhão, feita com base nas imagens em preto e branco e dos poucos desenhos que havia Sabe-se que Mies van der Rohe teve controle sobre os ângulos fotografados, a fim de evidenciar suas intenções de projeto.

Apesar de implantado no mesmo local do edifício de 1929, a proposta de construção de um pavilhão permanente exigiu alterações no projeto. Utilizou-se um novo sistema de impermeabilizaçao da cobertura, mais moderno e de melhor desempenho, portas toram instaladas, inexstentes no edflio de 1929, as peças estrulurais do projeto original, em aço comum, cromado, foram substituídas por aço inox.

Atualmente é a sede da Fundação Mies van der Rohe ${ }^{54}$ e foi sede do DOCOMOMO Internacional de 2010 a 2014. Não há no local nenhum registro ou informação que indique não ser esse o pavilhão construído em 1929, mas um clone ${ }^{55}$ dos anos 1980.

Brandi, muitos anos antes desse episódio, ou de outro similares, escreve, na Teoria da restauração que nesse tipo de ação [...] do ponto de vista da execução técnica, e, portanto, de
artesanato, pode ser, com efeito, reconhecido um valor de documento histórico. Mas o discurso é diferente quando se trata de reconhecer no falso um valor como obra de arte, sobretudo quando se tratar não mais de uma cópia que substitua um original, mas de uma interpretação, presumivelmente autônoma do estilo de um dado mestre. É necessário, entretanto, distinguir que a licitude da cópia, à parte o virtuosismo da execução, é
54 Fundació Mies van der Rohe Barcelona. Disponivel
em: <htip://miesbch.ocom/>. Acesso em: 20 dez. 2016 . 550 termo "clone" é utilizado por Ascensión Hernández
Martinez para designar caosos como esse de novas
construçōes que sáo supostas reconstruyoues. Para

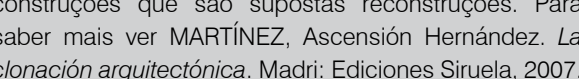



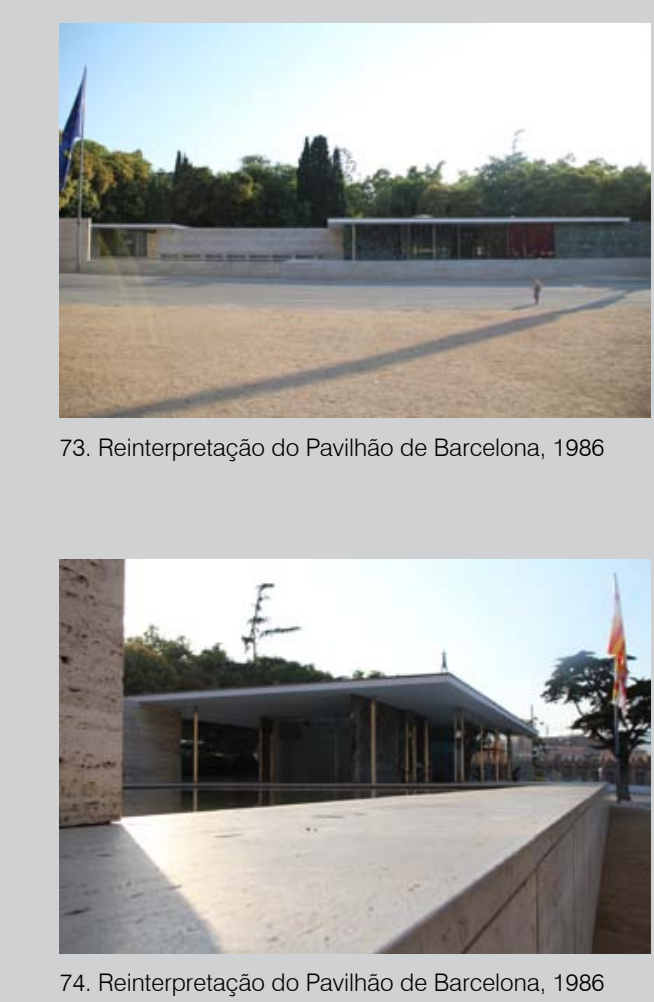

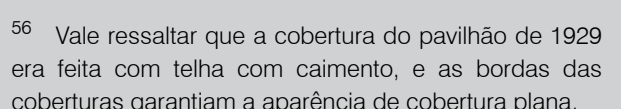

57 Após as grandes intervencóes para os Jogos
Olimpicos de 1992, Barcelona passa a ser uma das

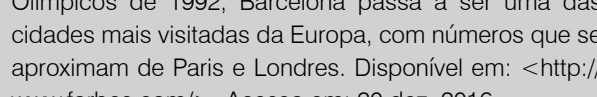

limitada, para a Estética, ao eco que transmite do original e que enfraquecerá de um tanto o original, todas as vezes que 0 reproduzir ou o divulgar. (BRANDI, 2004, p. 119)

Sobre o pavilhão de Barcelona há de se entender uma questão fundamental: foi construído para uma exposição e com a ciência de que seria demolido no final. Assim aconteceu. Essa náo serla uma caracterislica importante? Um valor a preservar, um partido de projeto? Transtorná-lo en um pavilhão permanente parece transgredir uma das suas principais características

Além disso, caso o pavilhão tivesse sido mantido, por qualquer razão que fosse, ele teria passado por um processo de envelhecimento, assim como passou a Torre Eiffel. Os materiais estariam gastos, os vidros, que naquela época eram feitos com outra tecnologia, estariam mais riscados, mais opacos, a cobertura já teria passado por diversos processos de manutenção para garantir a sua estanqueidade ${ }^{56}$, a estrutura teria marcas de corrosão. Sinais importantes para entender a ação do tempo. Da forma como se apresenta hoje, nega essa passagem temporal, confunde o visitante ou o pesquisador que são figuras importantes nesse processo. Um pesquisador atento saberá identificar a confusão que tais obras fazem e compreenderá as intenções por trás dessas ações e decidirá como inserir esses elementos ao encaminhar o seu trabalho. Já o visitante merece maior cuidado e respeito. Não deve haver apreciador de arte e arquitetura no mundo que se negaria a experimentar um espaco concebido por Mies van der Rohe ou Le Corbusier. Para isso, esses edifícios são perfeitos. Mas parece ser de bom tom trução desses novos edifícios. Desse modo, eles assumem um caráter didático fundamental.

No caso do pavilhão de Barcelona, essa releitura apresenta diversas alterações em relação ao projeto concebido por Mies van der Rohe. As dirterenças são, propositadamente, ocultadas a fim de dar o caráler de "Paviliháo do Mies". Visualmente, a "partitura" que o define, no entanto, é outra

A valorização simbólica do pavilhão se confirma quando passa a ser a sede do DOCOMOMO Internacional. Ratifica seu lugar como obra de Mies van der Rohe e patrimônio moderno. Essa postura coloca em discussão o olhar da instituicão para a efetiva preservação do moderno, que contradiz as diretrizes contemporâneas de preservação.

Barcelona, desde sua preparação para os Jogos Olímpicos de 1992, passou por uma transformação urbana extraordinaria. Na esteira dos investimentos para os jogos, fez uma verdacleira revoluçáo na cidade, com projetos de quallicação e melhoria plano para seu crescimento. Resultado disso foi atrair turistas do mundo inteiro ${ }^{57}$. Não se pode negar que a construção do pavilhão, em uma das áreas que recebeu muito investimento, tenha tido também essa intenção. O pavilhão está em um dos principais acessos ao Montiuiic, local onde foi construída a principal infraestrutura de esportes, como o Palau Sant Jordi e a Torre de Comunicações de Montjuïc (construída por Santiago Calatrava). Faz parte, portanto de um circuito de turismo e atividades econômicas importantes para a cidade.
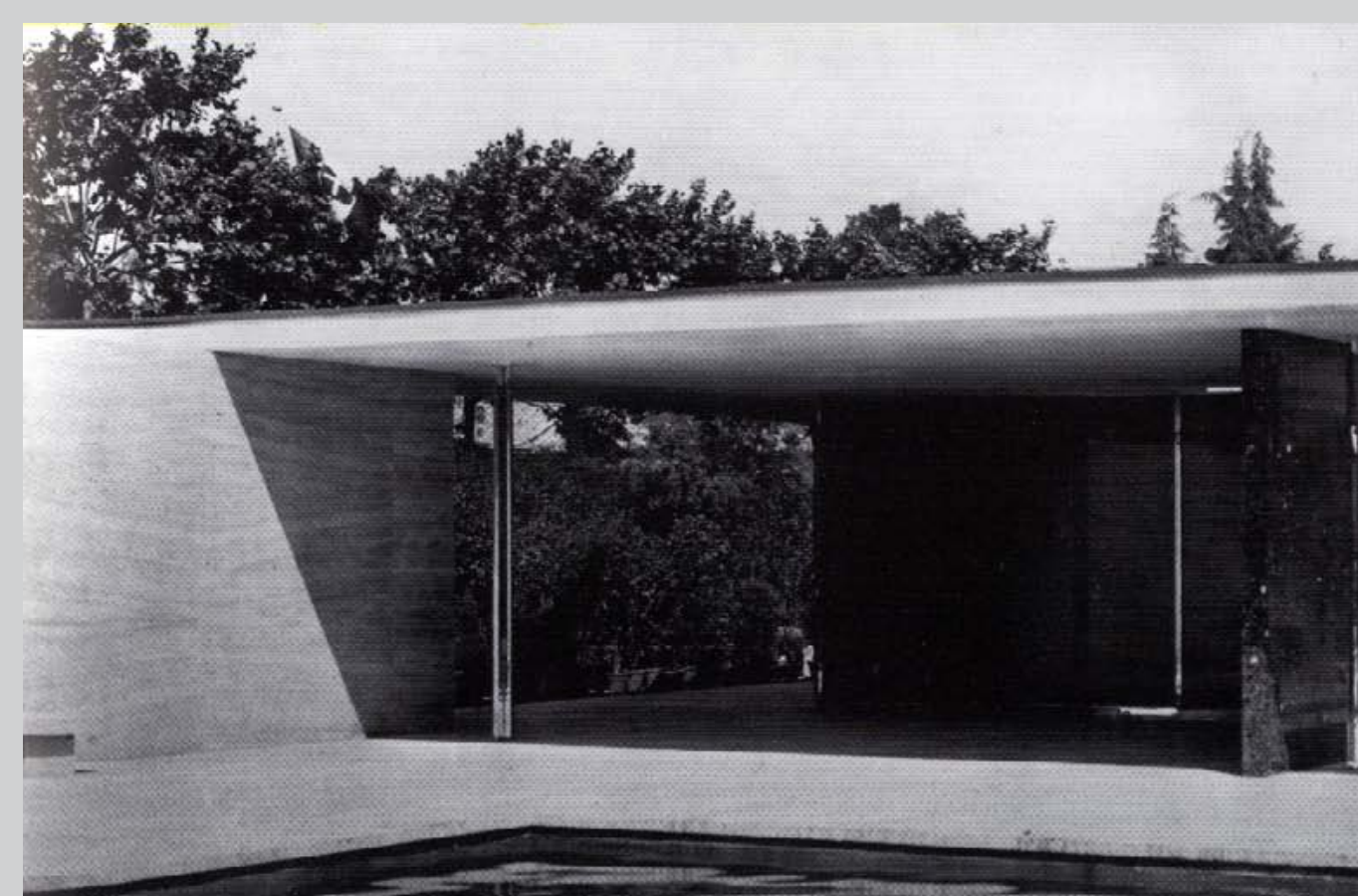
O Parque Ibirapuera, projetado por Oscar Niemeyer para as comemoraçôes do V Centenário de fundação da cidade de São Paulo, em 1954, é considerado o primeiro parque metro numerosas intervencões e, na grande maioria delas Niemeyer foi consultado ou mesmo contratado paçesé na grande maioria delas, Niemeyer foi consullado ou meslustrar toda a discussão zá-las. Assim, o parque mostrou-se um caso adequado para órgãos de preservação (IPHAN CONDEPHAAT a CONPRESP), a consulta aos processos nesses órgãos permitiu, mais do que conhecer os projetos propostos, estudar as discussões sobre cada caso, os posicionamentos divergentes e as contradições que evidentemente têm relação com a presença do arquiteto.

\section{Breve histórico}

Com $1.584 .000 \mathrm{~m}^{2}$ de área total, localizado junto a bairros nobres, o parque foi equipado com um conjunto de edifícios desenhados pelo arquiteto modernista Oscar Niemeyer, destinados a abrigar exposições comemorativas. Seu projeto tem uma dimensão simbólica significativa. Nele, a arquitetura, o urbanismo e o paisagismo dialogam e constroem, em conjunto, um discurso comum. (BARONE, 2007, p. 6)

A história do Ibirapuera tem início nos anos 1920 com o prefeito Pires do Rio, mas é no início dos anos 1950, com a criaçáo da cor tinha como objetivo não só a organização dos festejos como também a construção da ideia de futuro e a preservação da memória paulistana" (GURIAN, 2014, p. 20), que o parque é efetivamente projetado e construído.

O Parque Ibirapuera foi pensado como o núcleo principal dos festejos do IV Centenário. Logo após a formação da Comissão, o arquiteto Christiano Stockler das Neves (1889-1982) apesenta um projeto.

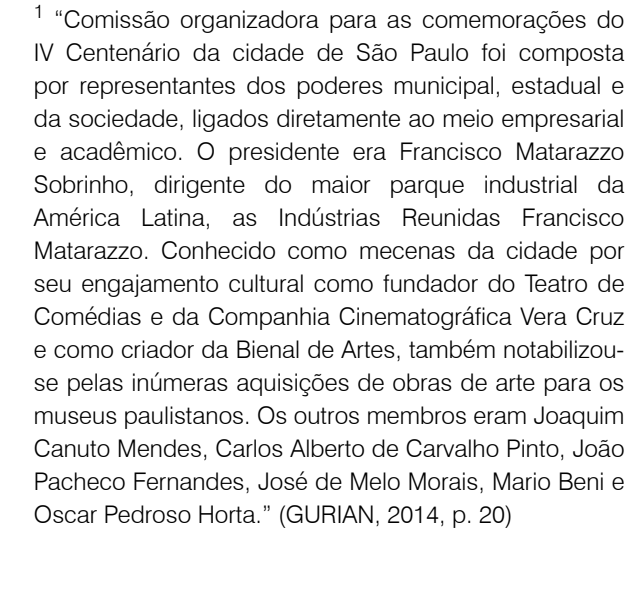


No parecer redigido por Stockler das Neves, o Parque do lbirapuera deveria ser uma criaçao artistica. Considerando também o caráter plano da superfície do lbirapuera, Stockler justifica em longo texto as características e, por conseguinte, sua opinião sobre os jardins ingleses, franceses e italianos, os quais seriam incorporados em sua proposta para o parque. (ANDRADE, 2004)

O projeto de Stockler das Neves priorizava as áreas verdes em detrimento de construções permanentes, o que repercutiu positivamente em setores da sociedade que defendiam a necessidade do parque para uma cidade que crescia em grande velocidade e que não privilegiava tais espaços².

O projeto final aprovado previa edifícios permanentes e alguns provisórios para atender às festividades do IV Centenário. Um projeto que promovia a imagem de modernidade, de progresso, mas que não teve maiores desdobramentos.

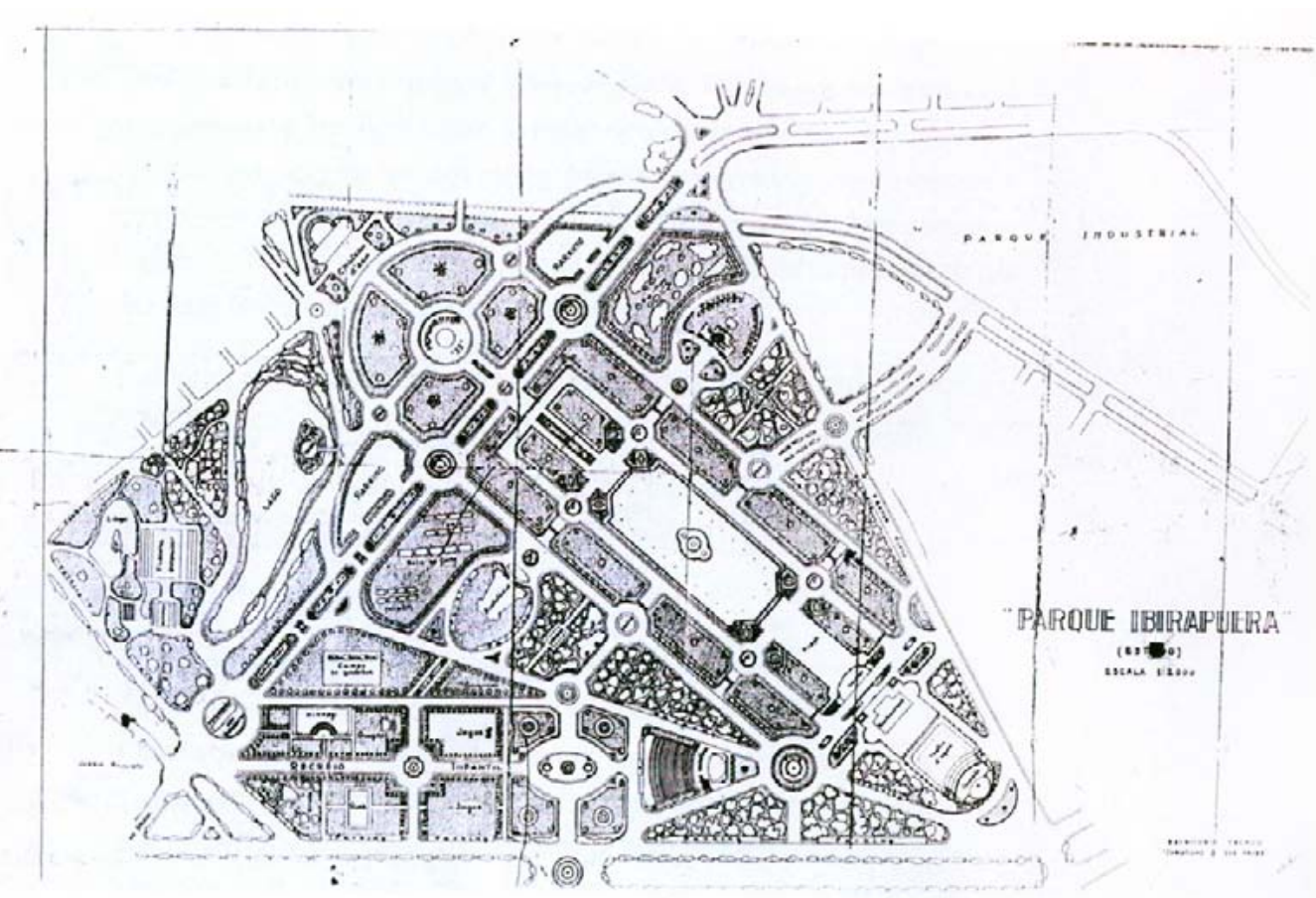

76. Projetto de Stockler das Neves

Francisco Matarazzo, com apoio do prefeito e do governador, decide compor uma nova equipe de planejamento. Pela escolha dos arquitetos, evidentemente se buscava uma nova abordagem para a comemoração, vinculada à imagem de progresso, de modernidade e que exaltasse a força da indústria paulistana.
A nova equipe era formada por arquitetos filiados ao moderno - Rino Levi, Oswaldo Bratke, Eduardo Kneese de Mello, Icaro de Castro Mello, Roberto Cerqueira Cezar, Alfredo Giglio, Carlos Brasil Lodi e Carlos Alberto Gomes Cardim Filho - e definiu um programa funcional base para as construcões do parque: Pavilhão das Indústrias, dos Estados, das Nações, Palácio das Artes e o conjunto esportivo.

Uma longa discussão se deu com o objetivo de consolidar o programa de necessidades e as demandas, já que:

[...] era preciso um território que, por um lado, abarcasse a memória evocada para São Paulo em 1954, e, por outro, expressasse a açaao politica realizadora do grupo responsável. Neste sentido, o Parque do Ibirapuera, alem de monumento que eternizava a memória do IV Centenário, transtorma-se no lugar ideal para onde deveria convergir a diversidade dos acontecimentos da celebração. (GURIAN, 2014, p. 47)

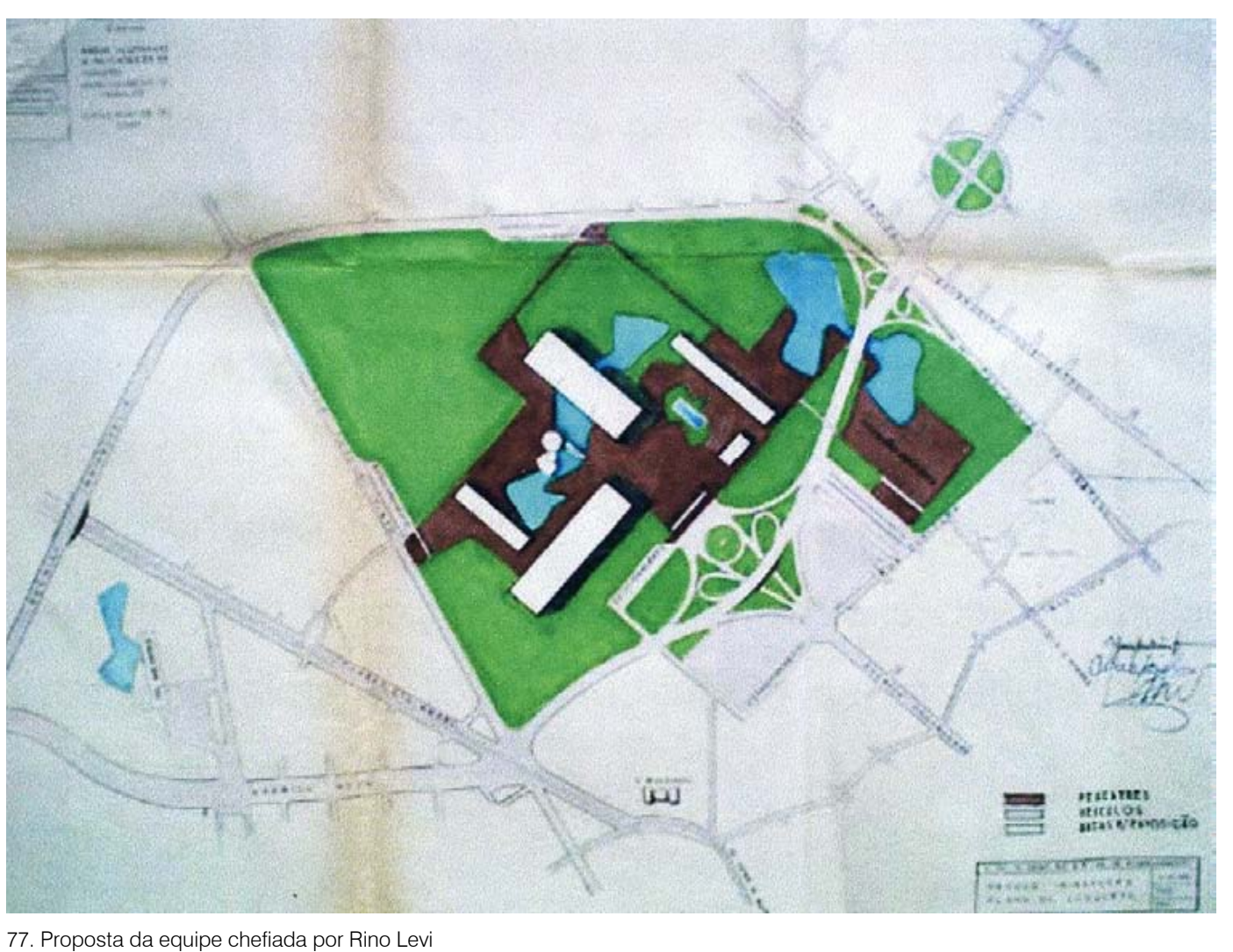




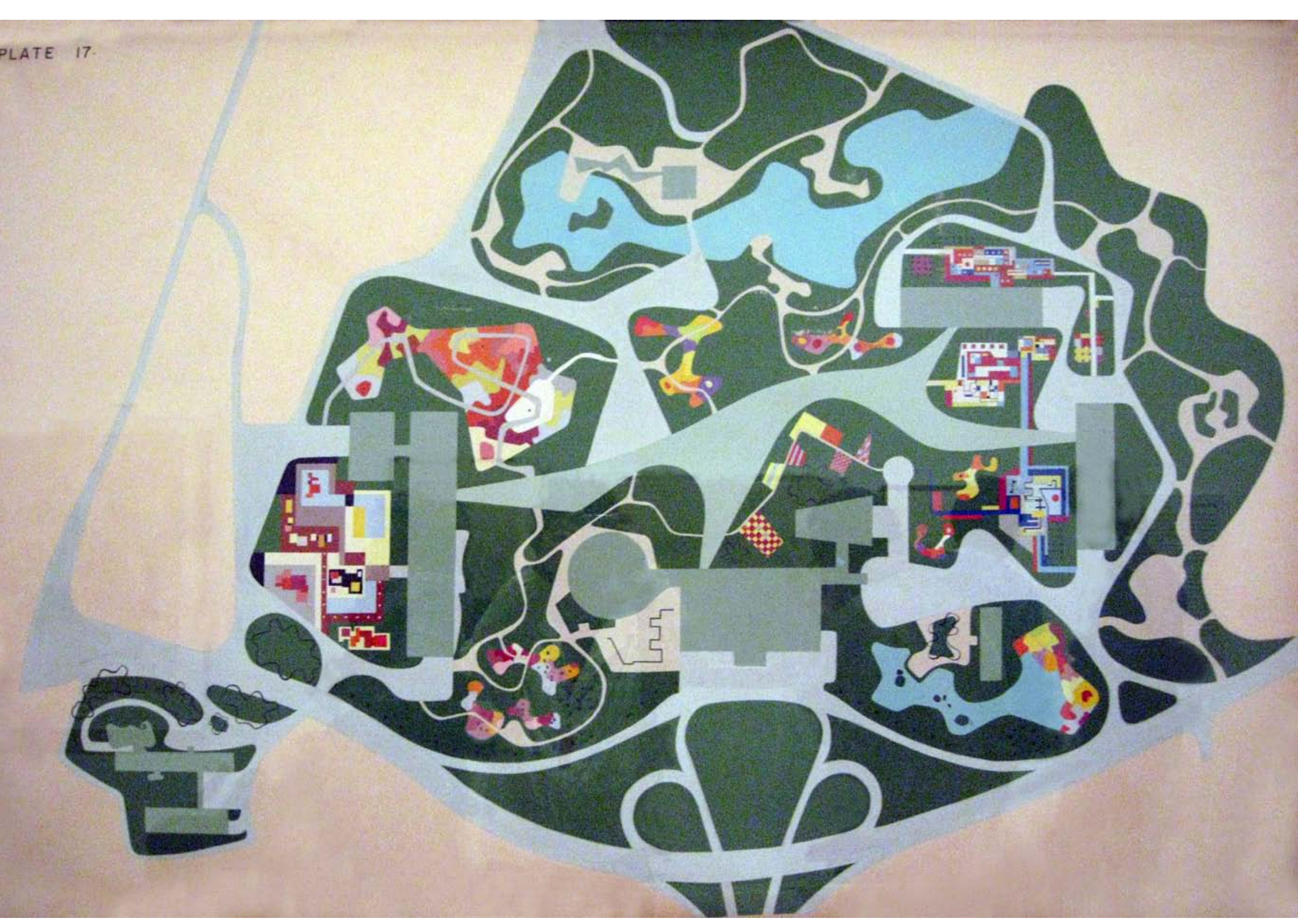

A equipe chefiada por Rino Levi apresentou um estudo de implantação para os pavilhões do parque, mas, segundo Gurian, a proposta financeira apresentada pelo grupo inviabilizou a continuação dos trabalhos.

Em 1952, Matarazzo convida Oscar Niemeyer para desenvolver um projeto para - Parque Ibirapuera. A decisão de contratar Niemeyer relaciona-se a outras questões além da reconhecida competência do arquiteto. Cabe colocar o esforço empreendido pelo grupo que formava o SPHAN, liderado por Lúcio Costa e Rodrigo Mello Franco de Andrade, para construir a identidade nacional a partir do moderno. $\mathrm{O}$ arquiteto proeminente que o grupo promovia era Oscar Niemeyer que, nesse momento, já tinha reconhecimento internacional Sua escolha tambem pode ser vista sob a necessidade de afirmação da identidade cultural moderna paulistana ${ }^{3}$.

O primeiro estudo apresentado parte da distribuição dos pavilhões pelo parque, todos unidos por uma grande marquise. Esse princípio se manteve no projeto construído. A arquitetura dos edifícios, entretanto, foi completamente alterada nos desenhos finais. O lago, com represamento dos córregos que passam no local, também já estava presente nos primeiros estudos. № acesso principal, os edifícios do planetário e do auditório são interligados por uma marquise reta que se conecta com a ponta da grande marquise, que sempre foi apresentada com uma geometria bastante sinuosa ${ }^{4}$. Nesse acesso também foi proposta uma plataforma elevada que permitiria observar todo o conjunto.

Evidentemente, com a evolução do projeto, informações sobre a topografia e a confirmação dos programas, foram feitas alterações gerais, da implantação do parque ao desenho dos edifícios, mas é possível reconhecer no projeto final e na obra construída a evolução do partido arquitetônicos

Roberto Burle Marx (1909-1994) desenvolveu um projeto de paisagismo que jamais foi implantado, já que a comissão organizadora preferiu trabalhar com a equipe do serviço público, comandada por Otávio Augusto Teixeira Mendes, chefe da seção de Parques, Jardins e Arborização.

Do projeto apresentado não foram construídos o auditório e a marquise - interligação entre a Oca, a grande marquise e o auditório que configuraria a praça de acesso principal e que permanece sem um desenho até os dias atuais ${ }^{6}$. Essa incompletude do projeto gerou uma reação da equipe de arquitetos responsáveis, que escreve um artigo para a revista Modulo intitulado "A verdade sobre o projeto e a construção do belo traçado destinado às comemorações do IV Centenário de São Paulo: a concepção, a realização e o que ainda pode ser feito
空

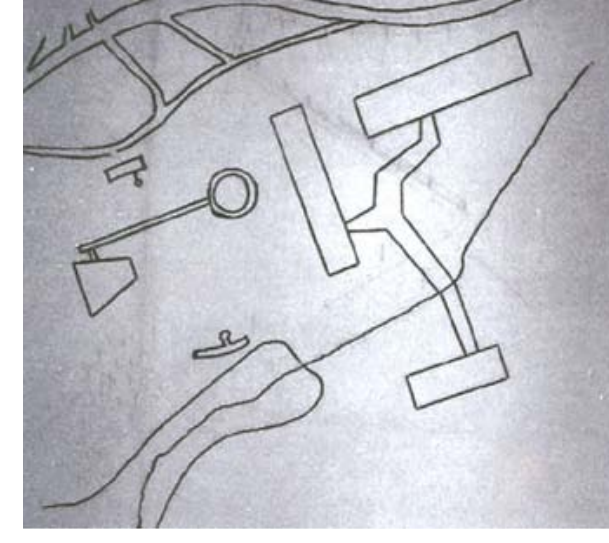

79. Croqui de estudo de Oscar Niemeyer

Pode-se questionar por que abiri mảo de uma arquitete carioca, para o desenvelvimente do trabalho
Evidentemente, naquele momento, Niemeyer bátem

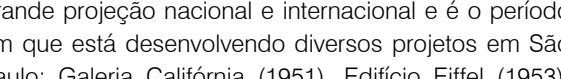
Eaulo: Galeria Califormia (1951), Edificioio Eifter

${ }^{4}$ Ao analisar as marquises na obra de Niemeyer, Marco marquises do arcuiteto poderiam estar sob influência $\mathrm{de}$ Gue jáno conjunto da Pampulha passa a ganhar "tormas e redesenhos sucessivos:

T. Jo desentho da marquise do projetto incial do Parque

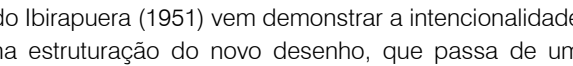
forma de tentáculos neurais orgânicos para um desenho antropomórifico próxin
NALLE, 2000, p. 224)

Partido arquitetônico entendido como a conceppáa os princíipis que condicionam o pro
não necessariamente o seu desenho.

Ésse tema seráretomado mais aciante, neste capitulo 


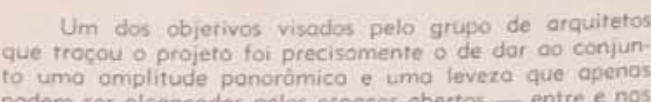

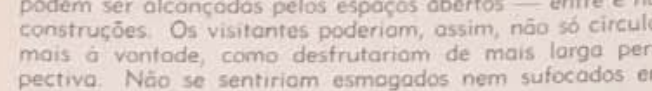

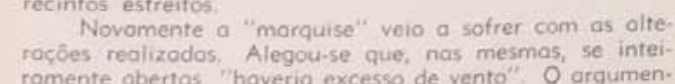

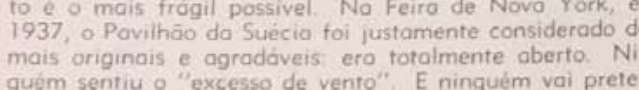

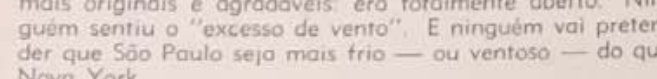

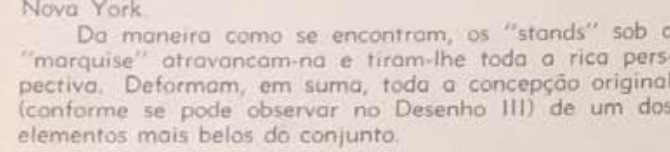

NOS PAVILHOES

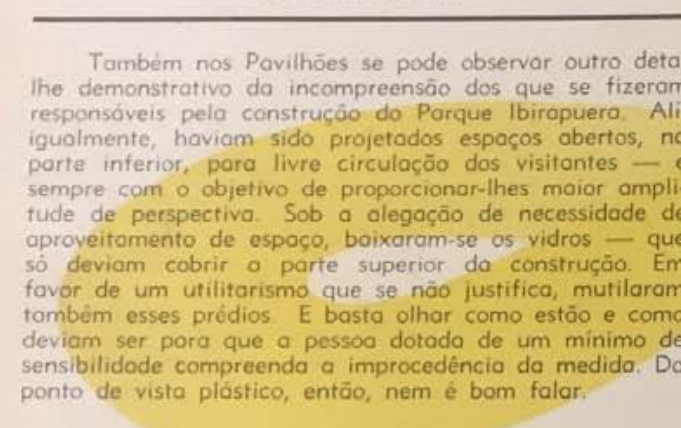

A ESPERANCA

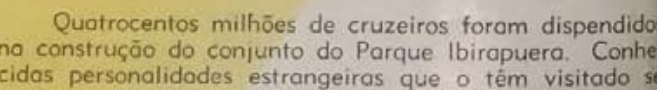

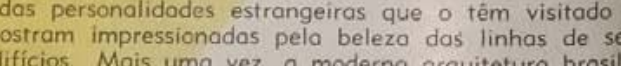

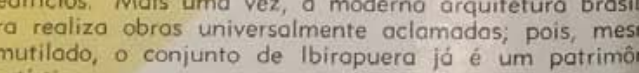

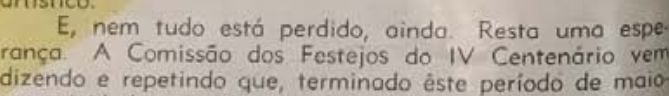

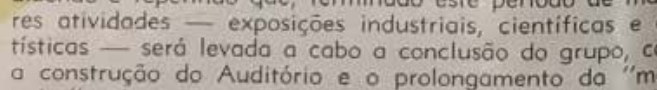

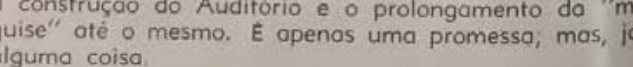

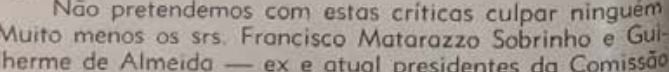

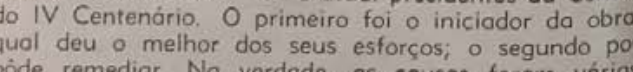

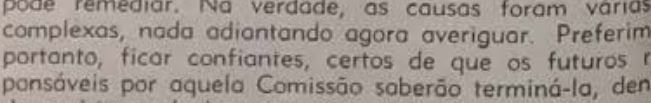

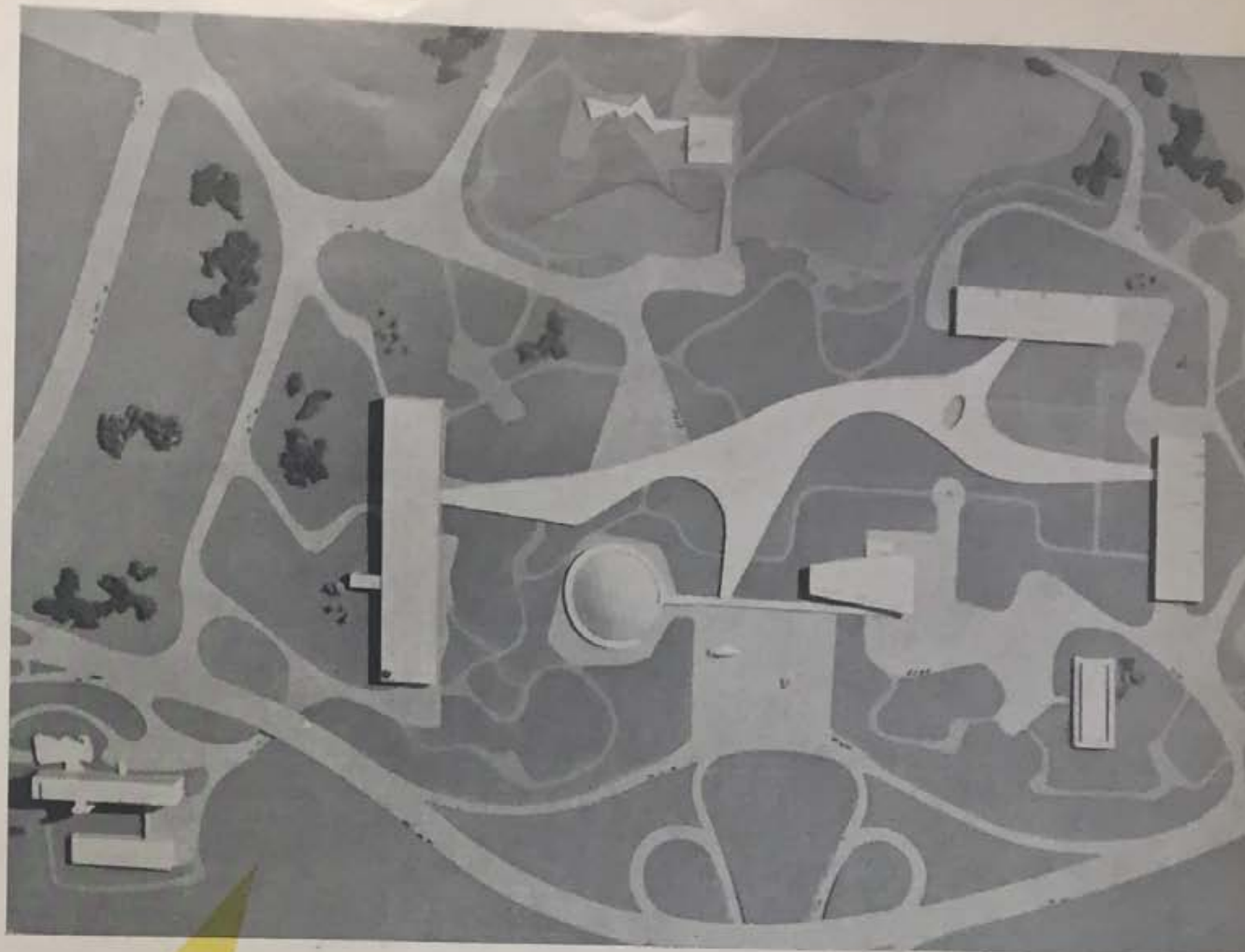

Fotos do "moquerte": Pode-se observor a importinncie do Auditiório no equilitbio

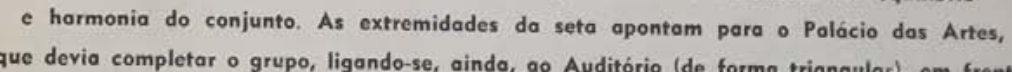

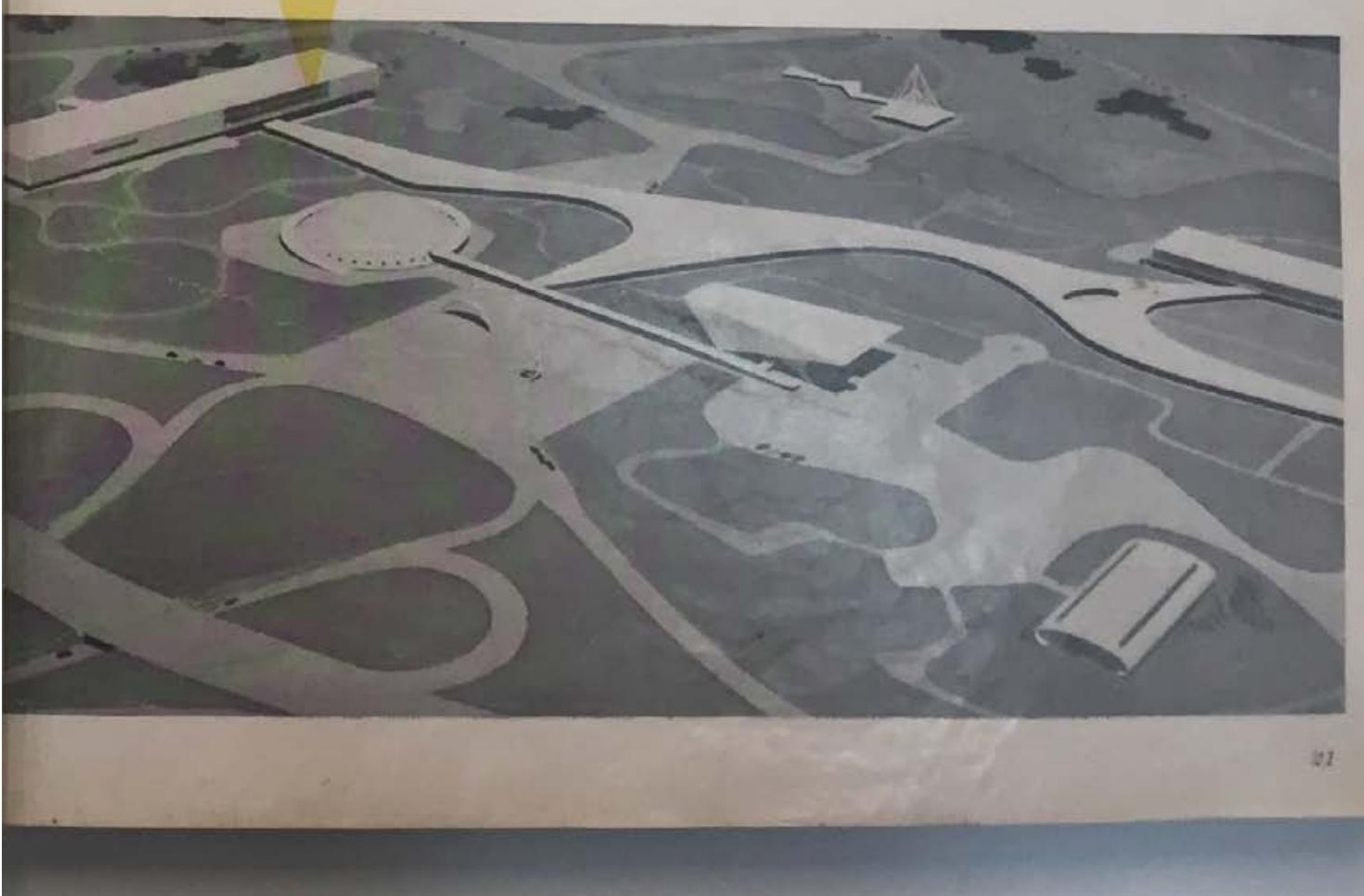




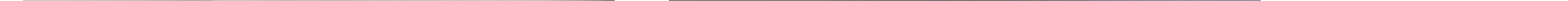




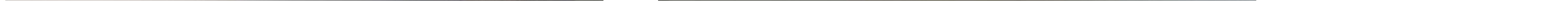




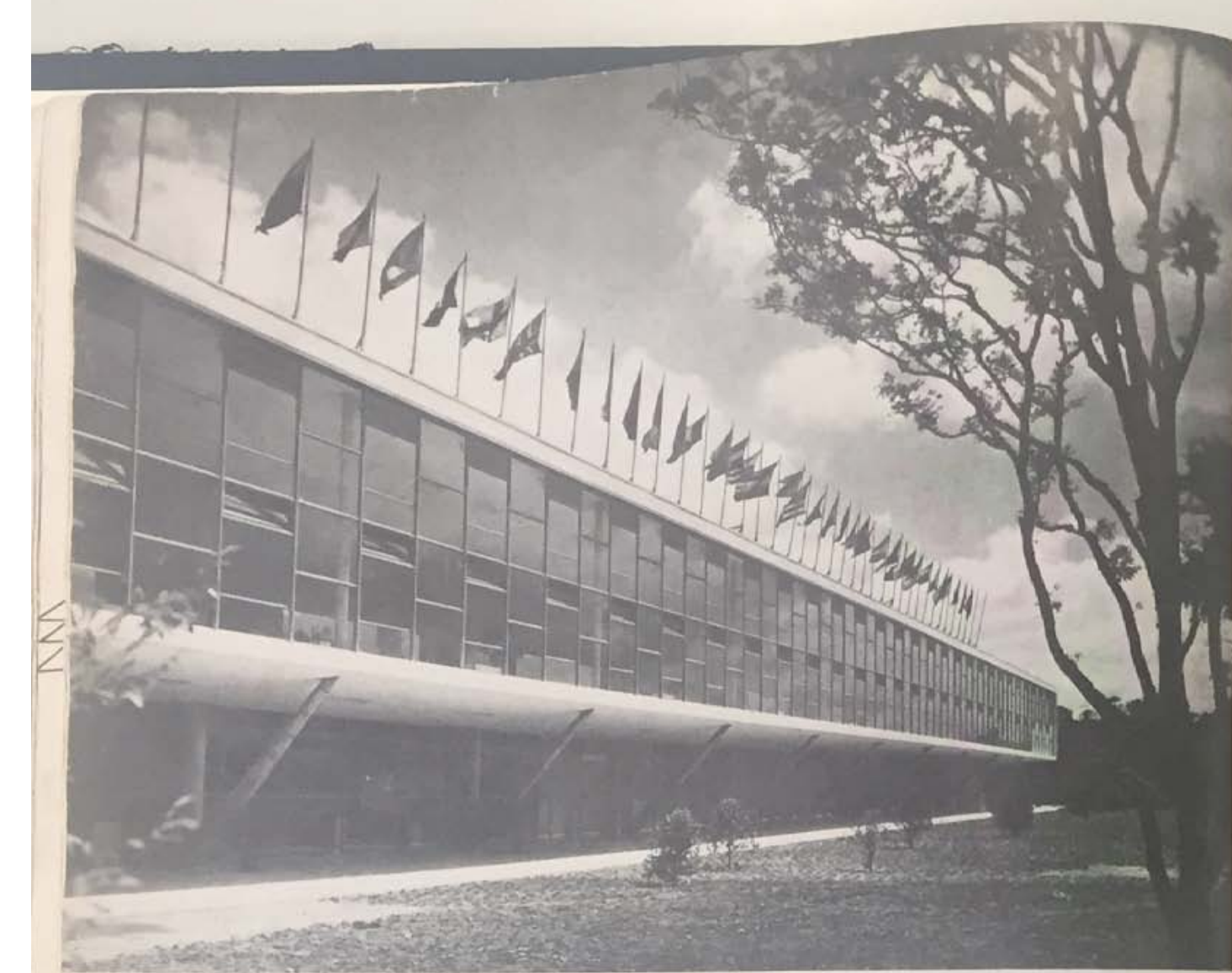

PALÁCIODAS NAÇÕES

PALÁCIO DOS ESTADOS

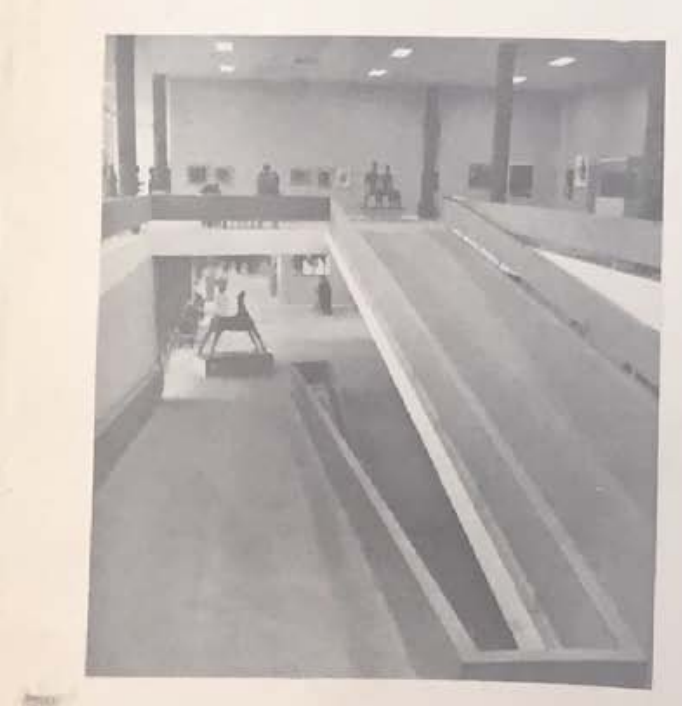

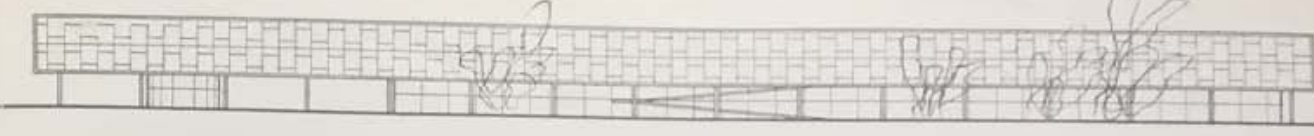

FACHADA SUDESTE

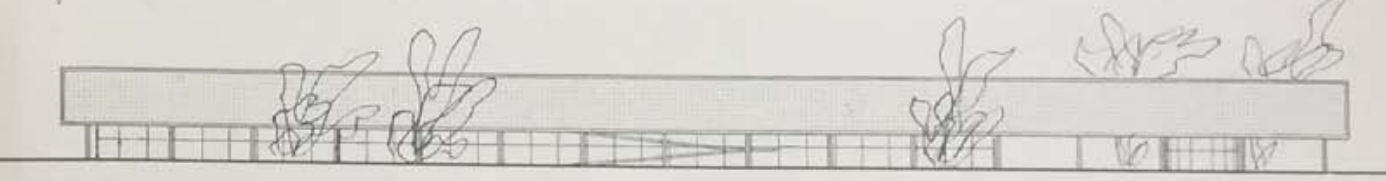

FACHADA NOROESTE

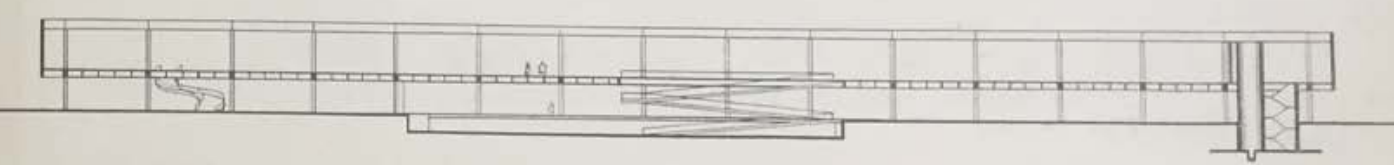

CORTE LONGITUINAL A.B

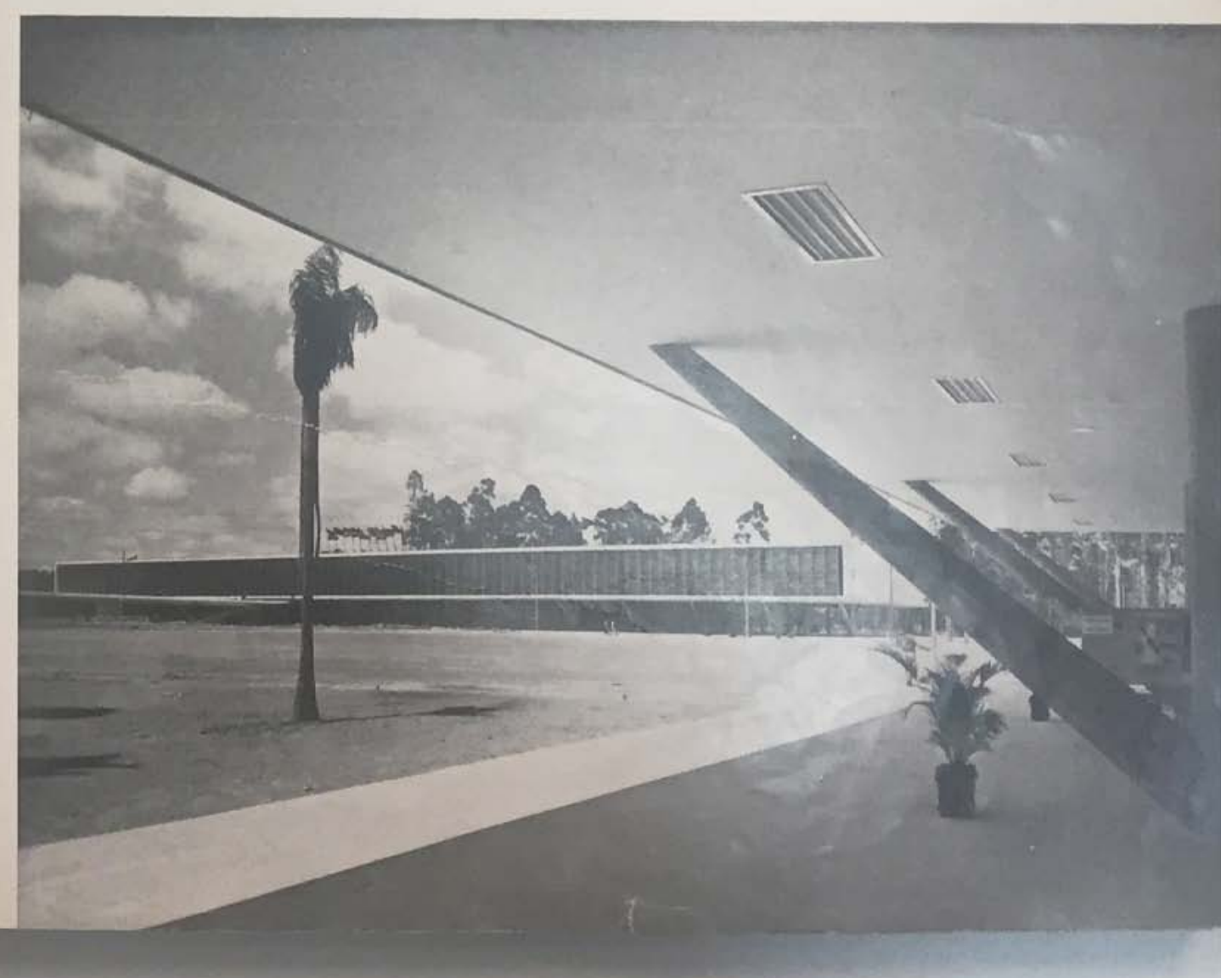


Lom

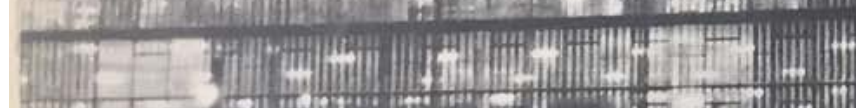

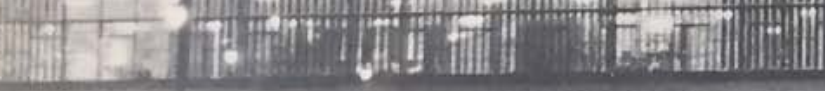

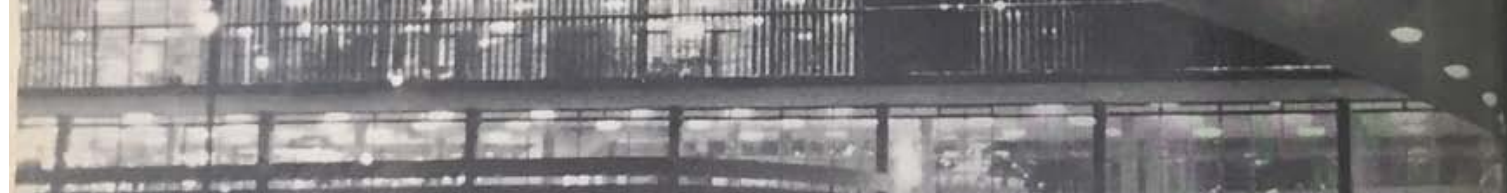

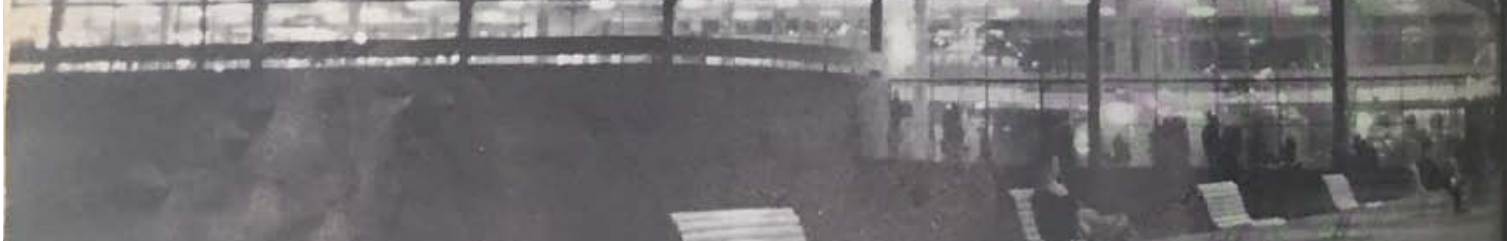
$2 \quad$ L
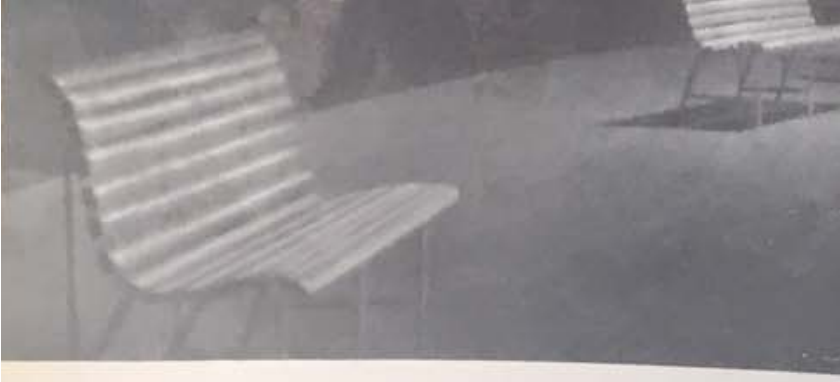
PALÁcIo DA AGRICULTURA

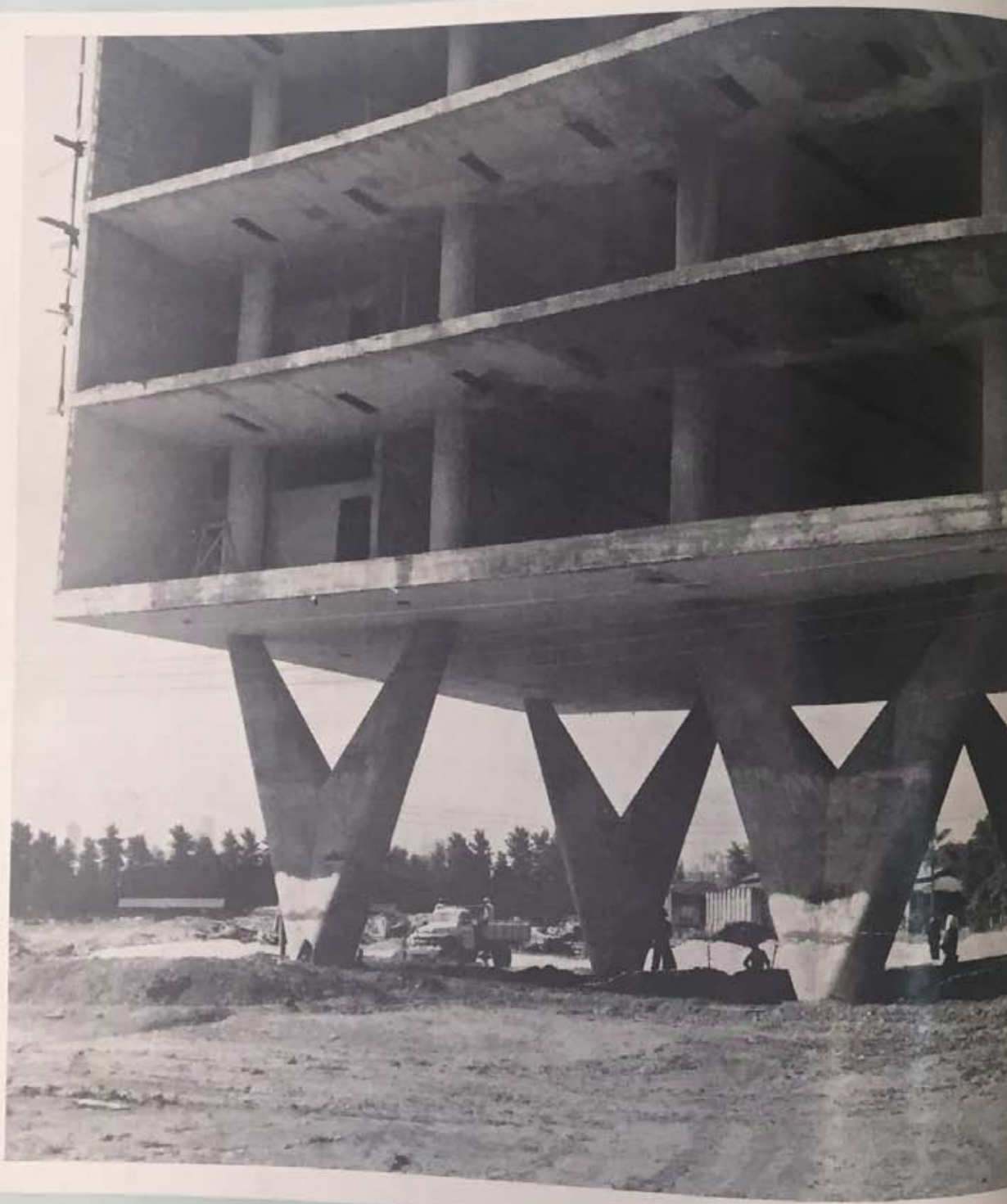

A fotografio mostra que o originalidade das colunas não foi
plástico: retivadou simplesmente por uma fantosio on coprich

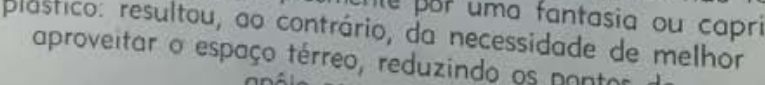

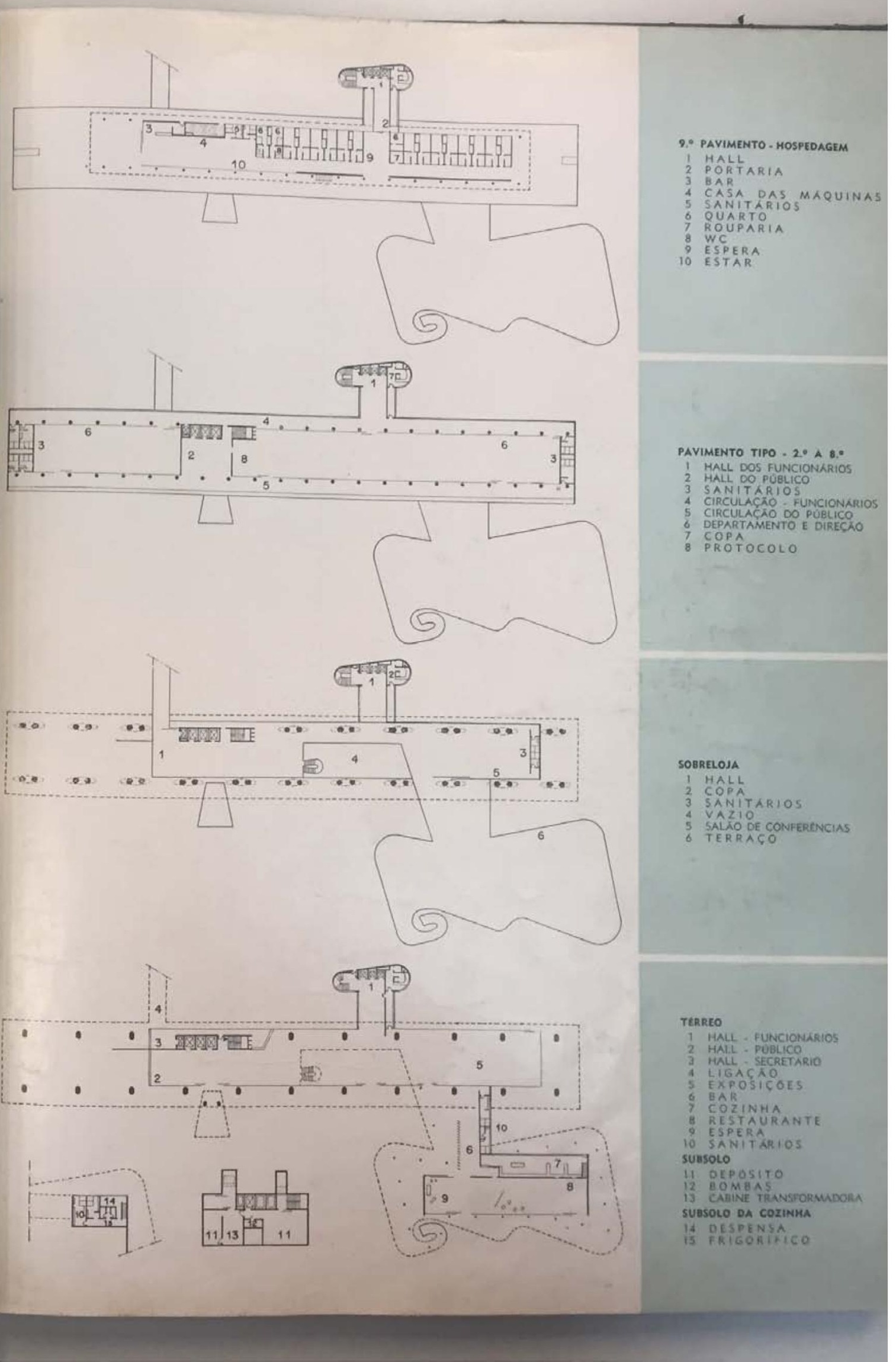


Em outubro de 1954, a revista Acrópole apresenta os edifícios e estandes da Exposição do IV Centenário. O texto que abre o artigo é bastante esclarecedor não apenas com relaça à grandiosidade da exposiçáo, mas também sobre a proposta e construção do parque e seus pavilhões:

Perto de três milhões de pessoas fazem de nossa terra um dos centros de mais rápido progresso de todo o mundo. Não é exagero. São Paulo apresenta um espetáculo grandioso pelas formas gigantescas de seu comércio. Há entretanto outros pontos que tornam a metrópole bandeirante deveras impressionante. Um deles, temos a noite, desde ao acender das luzes, quando a urbe magnifica se desfaz em cordéis de infinita luminosidade. São cordéis que tremeluzem com a mesma força, tanto no coração da cidade como no lbirapuera. Agora, todos os olhares de nossa metropole estao voltados para a obra gigantesca empreendida nesse local. E o espetáculo é de infinita grandiosidade! O lbirapuera, através de suas inúmeras manifestações, é testemunho fie da nossa verdadeira estatura econômica. Mas não é só. Também a arte, a ciência, a cultura enfim, estão lá representadas de forma magnifica. Ocupando a maior area até hoje concebida em São Paulo para iniciativas de tal natureza, a Exposição do IV Centenário e o nosso maior legado à postendade. So o Palácio das Indústrias ja e uma prova irrefutável disso. Mais de quinhentos stands estão lá instalados, dando aos interessados um quadro real da nossa capacidade de produção. Primorosamente decorados, esses stands são o que há de bom gosto [...] (ACRÓPOLE, n. 193, 1954, p. 53)

Segundo Marco do Valle

[...] no projeto do Conjunto Ibirapuera, Niemeyer propõe pela primeira vez uma concepção espacial que será recorrente em seu trabalho, uma derivada do conceito da "forma sobre plataforma e pilotis", que teve seu "grau zero", no late Clube (1940), juntamente com a concepção de duas formas diferentes interligadas à distância por uma marquise", com seu "grau zero" na Casa de Baile (1940). A síntese dessas concepções anteriores Niemeyer a realizará no conjunto formado pelo Palácio das Artes e Auditório (1951) do Ibirapuera. (VALLE, 2000, p. 201)

\section{Tombamento}

O Parque Ibirapuera é tombado pelos três órgãos públicos de preservação de patrimônio cultural (CONPRESP, CONDEPHAAT e IPHAN)?. Cada um deles, com estruturas distintas e autônomas, estabelece nas suas resoluçōes de tombamento abordagens diferentes, com atribuições de valor que consideram questões diversas. As decisões dos órgãos não são concorrentes nem hierárquicas, ou seja, no caso do lbirapuera, para qualquer intervenção proposta é necessária a aprovação nas três esferas. Caso haja algum indeferimento, este prevalece ${ }^{8}$

A resolução de tombamento do Parque Ibirapuera elaborada pelo CONPRESP é a mais sintética das três. Cita apenas o perímetro de tombamento e a necessidade de preservar o traçado urbano, a vegetação e área permeável: "A vegetação de porte arbóreo e os ajardinamentos públicos e particulares que assim definem e preservam a área permeavel do perimetro" (CONPRESP, 1997). Trata-se de um tombamento de uma área da cidade que náo especilica nenhuma questao relacionada à qualidade arquitetônica dos edificios do parque, a não ser no que diz respeito à sua volumetria. E importante frisar que a resolução năo faz distinção entre as construçoes internas e externas do parque. Há uma sêre de altraçoes posteriores que tratam da questao das areas enambiental do parque e da cidade ${ }^{10}$

A resolução do CONDEPHAAT tem uma definição mais clara a respeito do tombamento do parque. Inicia pela proteção de toda a área verde em seu interior, considerando a carência de áreas verdes no municííio. Em seguida, lista os edifícios protegidos: Palácio das Nações (Pavilhão Manoel da Nóbrega), Palácio dos Estados (Pavilhão cez), Palácio das Indústrias (Pavilhão Armando de Arruda Pereira), Grande Marquise de cez), Palácio das Indústrias (Pavilhăo Armando de Arruda Pereira), Grande Marquise de Interligaçao dos Pavilhoes e as edificaçoes sob a mesma (antigo Museu de Cera, que
integra parte da área atualmente ocupada pelo MAM, antigo Pavilhão de Exposiç̃es integra parte da area atualmente ocupada pelo MAM, antigo Pavilhão de Exposições,
antigo lunchbar blocos de sanitários e central de telefonia), Planetário Municipal Instituantigo lunchbar, blocos de sanitários e central de telefonia), Planetário Municipal, InstituSiderúrgica Nacional). Estabolece, entre outras diretrizes, que "[. ] não será permitido

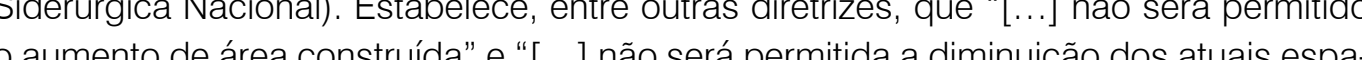
ços permeáveis e/ou cobertos por vegetação em toda a área do Parque"12

A resoluçáo ainda sugere adequaçōes do espaço, principalmente no que diz respeito às ocupações posteriores à construção do conjunto:

Somando-se a isto, aproveitando a oportunidade da saída da Prefeitura e da Prodam dos prédios que ora ocupam, prevista pela

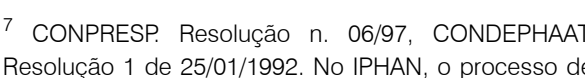

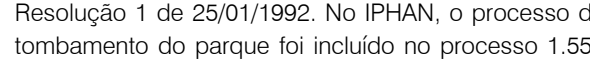
de tombamento das obras do arguiteto oscar Niemeyer,
que até o momentionano foi concluido (confirme
apresentado no capitulo 2 )

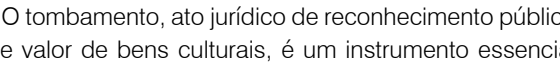
(a) preservagăáo e conservaçăo dos bens aos quais atribu

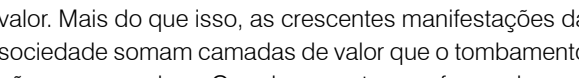

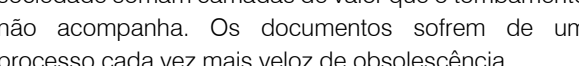
Essa resoluçăo passou por várias alteraçöes que gulam as construçóoes externas ao parqu

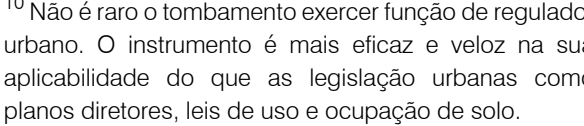
11 Pavihảo Japonês, doado pela Colônia Japonesa a
Săo Paulo. É reproduçăo do Palácio Katura de Kioto construido inteiriamente com material importaca do Japão, por técricos
(CONDEPHAT, 1991, p. 497).

2 CONDEPHAAT. Resolugạa 1 de 2501/1992

IBIRAPUERA 
lei 10.929 de 11 janeiro de 1991, sugerimos a relocação de museus e outras atividades instaladas sob a marquise, que ao longo do tempo tem sido indisciplinadamente ocupada, criando novos compartimentos fechados que prejudicam a leitura de seu espaço grandioso, culminando com uma lanchonete cujas instalaçōes criaram anexos cobertos contíguos a esta marquise, prejudicando totalmente este núcleo central de comunicação entre os paviIhões. (CONDEPHAAT, 1991, p. 498)

Já no IPHAN, a proposta de tombamento se restringe especificamente aos edifícios projetados por Niemeyer para o parque:

Por sua relevância urbanística e cultural poderão ser inscritos no Livro do Tombo Histórico e no Livro do Tombo das Belas Artes. São eles: a Grande Marquise, o Palácio das Nações (Pavilhão Manoel da Nóbrega, atualmente ocupado pelo Museu Afro Brasil), o Palácio dos Estados (Pavilhão Francisco Matarazzo Sobrinho, atualmente desocupado), o Palácio das Indústrias (Pavilhão Armando de Arruda Pereira, atualmente ocupado pela Fundação Bienal), o Palácio de Exposiçōes ou das Artes (Pavilhão Lucas Nogueira Garcez, também conhecido como Oca, atualmente ocupado para grandes exposições), e o Palácio da Agricultura (atualmente ocupado pelo Museu de Arte Contemporânea da USP). ${ }^{13}$ Conforme colocado anteriormente, esse processo ainda não foi homologado,
ssou a fazer parte do tombamento das obras de Oscar Niemeyer que ainda tramita no órgão. Seguindo o regimento do IPHAN e das demais entidades de preservação, a partir da abertura de um processo de tombamento, as obras em análise passam a ficar sob tutela do órgão e qualquer intervenção deve ter prévia autorização. Portanto, independentemente da conclusão do processo, os edifícios do Parque Ibirapuera estão provisoriamente preservados pelo IPHAN".

Cabe comentar a dificuldade, nos três casos de tombamento, de estabelecer os valores e as diretrizes de um conjunto como o do Ibirapuera nas resoluções que pautam as decisoes dos orgäos en relaçáo ao bem cullural. A ideia de una resoluçáa que

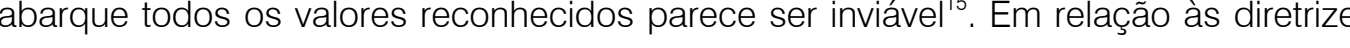
vem ser suficientemente claras para que se possa efetivamente preservar, mas também suficientemente flexíveis para que se possa intervir sem correr o risco de inviabilizar a preservação e pleno uso dos bens culturais.

No caso da resolução do CONDEPHAAT, no episódio da solicitação de construção do novo auditorio - que será discutido mais adiante - o Conselho, a partir de um texto de Ulpiano Bezerra de Menezes, demonstra os problemas da redação da resolução, principalmente no que diz respeito à probiça de aumento de área construla, quando ventradição da proibição com a regra de que

[...] todas as mudanças de uso das edificações, assim como as intervençōes nas áreas tombadas - demoliçōes, construçōes, reformas, obras de conservaçaao e restauração - serão objeto de prévia deliberaçāo do CONDEPHAAT [...]tem-se que reconhecer que a Redação da Resolução é infelize tecnicamente insatisfatória, pois daria margem a ambiguidades numa leitura sumária e apenas
literal [...]com efeito, não é cabível admitir-se a proibição em gênero de quaisquer construções novas e, ao mesmo tempo definir diretrizes destinadas a reger "todas as obras de [...] construções" e, para culminar o absurdo, exigir que "construçōes" (novas, por . (CONDEPHAAT, 1994, p. 99)

A análise dos casos a seguir trata de compreender os acontecimentos no Parque Ibirapuera a partir da leitura mais abrangente possível dos valores atribuídos e das diretrizes contemporâneas de preservação de patrimônio cultural, sem se restringir às que foram estabelecidas pelos órgãos de preservação. Pretende mostrar, conforme discipalmente, da interferência do arquiteto-autor e dos membros de sua equipe.

\section{Intervenções no parque}

Desde sua inauguração, foram numerosos os processos de intervenção no lbirapuera, como é de se esperar para um espaço público numa cidade como São Paulo, que teve um processo de transformação enorme desde a construção do parque nos anos 1950. Pela sua importância na cidade e por se tratar de uma obra de Niemeyer as intervençoes têm ampla repercussão na sociedade. Fica evidente que a discussão sobre a sua preservação trata sempre da sobreposição e confusão de três aspectos: as 
construções propriamente ditas, o projeto original e a autoria de Oscar Niemeyer, que fo sistematicamente consultado a respeito das intervenções até a sua morte em 2012.

Como será apresentado adiante em diversos casos, em vez de concentrar as discussões nas propostas de intervenção - se são compatíveis com a preservação desejada - as diversas abordagens se atrapalham mutuamente, evocando, em cada caso argumentos diversos e muito contraditórios.

Tombar o Parque Ibirapuera não pode significar a impossibilidade de interferir no seu conjunto. Como discutido no capítulo anterior, os projetos originais ${ }^{16}$ não podem ser tomados como representação fiel do conjunto construído e também não são, obrigatoriamente, os documentos que estabelecem as novas possibilidades dentro do parque. Eles são essenciais, no entanto, para a compreensão dos princípios que nortearam proposta. A constante consulta ao arquiteto-autor também deve ser considerada com cautela.

O parque não pode ser compreendido apenas com os valores reconhecidos no projeto e na construção original. A apropriação do conjunto pela população, suas numerosas possibilidades de uso, o desenvolvimento urbano, as novas demandas da sociedade sáo camadas de valor que se sobrepóem e precisam estar na pauta das discussoes de intervençâa, para que se possa agir considerando o pleno uso e a preservaçăo. Os usos propostos orginalmente ja foram alterados muitas vezes, diversas construções té hoje. É com este Ibirapuera que existe hoje que é necessário dialogar.

Se no projeto original havia edifícios que jamais foram construídos, não há nenhum compromisso imperativo para a sua finalização. Uma vez terminada a obra esse - Parque lbirapuera, conclúído, dentro das condiçôes possiveis Não significa dizer que era, então, uma obra fechada, vedada a novas intervenções.

A análise dos casos a seguir pretende mostrar a dificuldade de discussão, a sobreposição de leituras de valor e a relação com as diferentes atuações dos órgãos de preservaçâo. Evidencia a dificuldade de separar uma leftura do parque como patrimônio cultural de seu projeto oniginale da aluaçao do aqu liteto-autor como dono absolut obra. A proposta é perceber, a partir da discussáo dos projetos propostos - realizado ou não - a dificuldade de lidar com o parque e essas outras instâncias que invariavelmente se impõem.

Os projetos estudados a seguir dizem respeito ao período posterior ao reconhecimento do lbirapuera como bem cultural pelos órgãos de preservação. A partir da abertura do processo de tombamento, toda e qualquer intervenção no parque deveria ser submetida aos órcãos. Assim, os processos apresentam diversas situaçoes, com as solicitações dos proponentes e as discussões que se seguiram.

\section{Ampliação do Pavilhão das Indústrias - edifício da Bienal}

Em março de 1994, Oscar Niemeyer escreve uma carta endereçada ao então presidente do CONDEPHAAT, o arquiteto José Carlos Ribeiro de Almeida, justificando o pedido de construção de um espaço anexo ao edifício da Bienal "[...] compreendendo locais de encontro, um grande auditório, restaurantes, bares, etc. daria ao conjunto outra importância convocando a população, criando o ambiente indispensável ao conhecimento e à difusão das artes plásticas" (CONDEPHAAT, 1994, p. 2).

Sua argumentação parte do fato de que o parque não havia sido concluído uditório existente no projeto original que havia sido pensado junto ao edifício da Oca.

Nessa mesma correspondência, Niemeyer reforça a importância de ser ele o autor do projeto e, portanto, autorizado a intervir no bem tombado

[...] e gostaria de lembrar o critério que, em caso idêntico, está sendo adotado nas modificaçōes que serão feitas no edifício-sede do Ministério da Educação e Saúde - já tombado - permitindo aos arquitetos responsáveis pelo projeto qualquer alteração ou acréscimo que considerem necessários para o bom funcionamento do edifício, ficando claro que sem a presença deles nada mais poderá ser feito nele, pois cada arquiteto tem sua maneira própria de ver a arquitetura. E isto que nos parece de clareza irrecusável deveria valer também para o prédio da Bienal. (CONDEPHAAT, 1994 , p. 3)

Após extensa discussão a respeito da solicitação, o CONDEPHAAT manifesta-se contrário à aprovação do projeto. O argumento principal para a decisão está amparado na resolução de tombamento (SC-1 de 25/01/1992), que estabelece que não será permitido o aumento de área construída e nem a diminuição de áreas permeáveis no parque.

Há pouca documentação de imagens desse processo, o que evidencia que a questão não foi discutida a partir da leitura do bem cultural e do impacto da intervenção proposta. Não há nenhuma discussão a respeito do projeto propriamente dito

Era um programa compatível com o parque? O programa ampliaria e qualificaria as atividades desenvolvidas no edifício da Bienal? Seria uma intervenção de fato danosa ao conjunto? 
Em uma correspondência para o arquiteto Fábio Penteado, presidente da Fundação Bienal, José Carlos Ribeiro de Almeida, o presidente do CONDEPHAAT, expressa a sua compreensão sobre o tema e a dificuldade para a aprovação do projeto: "O tombamento, em consequência, teve como objetivo manter o parque no estado atual evitando novas intervençōes e edificaçōes, preservando dessa forma o bem cultural" (CONDEPHAAT, 1991, p. 914) ${ }^{17}$

O parecer da área técnica confirma a hipótese levantada apontando que a resolução de tombamento não permite aumento de área construída dentro do perímetro tombado do parque: "Independente do autor, do seu renome e competência, não dente perigoso, acabando por enfraquecer a própria lei" (CONDEPHAAT, 1991) (18 $^{18}$.

O projeto não é aprovado pelo Conselho, que vota em conformidade com a área técnica. Não há maiores desdobramentos desse processo e nada mais é discutido. Esse é apenas um caso, de uma sequência de fatos similares, cada qual tratado de forma diferente como será visto a seguir.

\section{Plano Diretor}

Desde a inauguração, o parque passou por numerosos problemas referentes a estacionamento de carros, construções feitas sem autorização ou controle e uso indevido dos espaços. Os usuários e moradores dos arredores se organizaram em associações e sempre se posicionaram a favor da preservação - não necessariamente como bem cultural - do parque público.

Em 1996, a prefeitura decide contratar Niemeyer para elaborar um plano diretor para a conservação do Ibirapuera

Evidentemente, mais do que conservá-lo, Niemeyer tinha uma leitura absolutamente contemporânea sobre o parque, questionava seu estado propondo numerosas intervenções. Logo na introdução, já esclarece: "Nada de concessões, nada de atender apelos que o desmereçam. O importante é o Parque do Ibirapuera e o conjunto arquitetônico nele construído". A única menção em relação ao projeto original é sobre a "[...] realização no Ibirapuera do Grande Centro de Arte"

A primeira questão apresentada por Niemeyer foi a possibilidade de intervenção na entrada principal do parque. A solução proposta foi construir um grande estacionamento no local e também um auditório - que já havia sido proposto no projeto de 1954 mas com desenho completamente diverso. Seria, segundo o arquiteto, a possibilidade de concluir o acesso principal que não pôde ser realizado nos anos 1950.
Também são determinados os usos dos edifícios, sempre vinculados às artes: exposições, auditórios, bibliotecas, locais de encontro etc.

Seguindo a diretriz de "[...] total desocupação da grande marquise que, conorme projeto original do Arquiteto Oscar Niemeyer, deverá ser mantido totalmente livre para a integração dos Museus ali existentes" , o plano prevê que para o "[...] Museu de Arte Moderna, construldo debaixo da Marquise, seria destinado, como as plantas indicam, um novo espaço, com 3.000 m"

Em seguida, é solicitada e autorizada a remoção das seguintes construções existentes sob a marquise: "Sanitário, cabines primárias, cabines telefônicas, ASSUAPI (Associação dos Usuários e Amigos do Parque Ibirapuera) 21. ||I Millenium"22.

A contratação de Oscar Niemeyer para desenvolver o Plano Diretor, ou seja, um plano para o futuro do parque, evidencia, entre outras questões, a dificuldade de abordar o conjunto sem a anuência do arquiteto-autor. Como se fosse dele a única possibilidade de uma leltura crtlica sobre o estado de conservaçáa e sobre planos futuros. Tanbén é possivel observar no plano um olhar distanclado do parque real, existente. espaço. É uma leitura superficial pautada no plano original e em propostas novas de ocupação.

Entretanto, há de se observar que nenhuma proposta do plano fere os valores reconhecidos no parque. A desocupação da marquise, inclusive com a remoção do MAM (Museu de Arte Moderna) e sua instalação em outro ponto do parque, parece uma solução adequada à sua preservação e pleno uso - este tema será retomado mais adiante. Essa liberação de fato acontece e contribui muito para a fruição do espaço já que o deixa livre para uso público. As construçōes existentes estabeleciam um recorte do espaço e uso privativo. As demais propostas, como o projeto do acesso e a alteração do MAM, não são levadas adiante.

É interessante notar que o plano não considera as restrições colocadas na reente, proibia novas construções. O mesmo Niemeyer, que dois anos antes tinha recebido do órgão uma neguiva para a mervenca no edflio da Bienal, ignoa o fato e propõe intervenções que, em princípio, jamais seriam aprovadas.

Do ponto de vista da gestão do parque, um plano que organizasse as intervenções e ações de consenvação seria muito bem-vindo. Não significaria um instrumento que engessasse as ações no parque. Pelo contrário, um documento que poderia ser revisto de tempos em tempos, incorporando novos valores e novas demandas. Da forma como foi apresentado, pouco contribuiu para a preservação do Ibirapuera, principalmente porque tem um olhar de continuidade de implantação do conjunto, com grand abras e não uma abordagem cuidadosa voltada para a conservação do existente ${ }^{23}$.
19 Ofício 426/SVMA-G/99, assinado pelo Secretário
Municipal do Verde e do Meio Ambiente Ricardo Ohtake
(Acervo IPHAN)

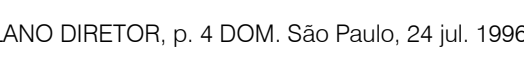

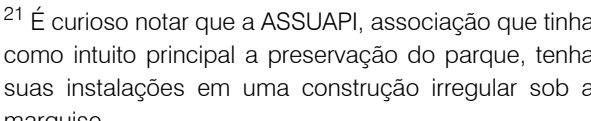
marquise

Oício 426/SVMA-G/99, assinado pelo secretétí Municipal do Verd
(Acervo IPHAN).

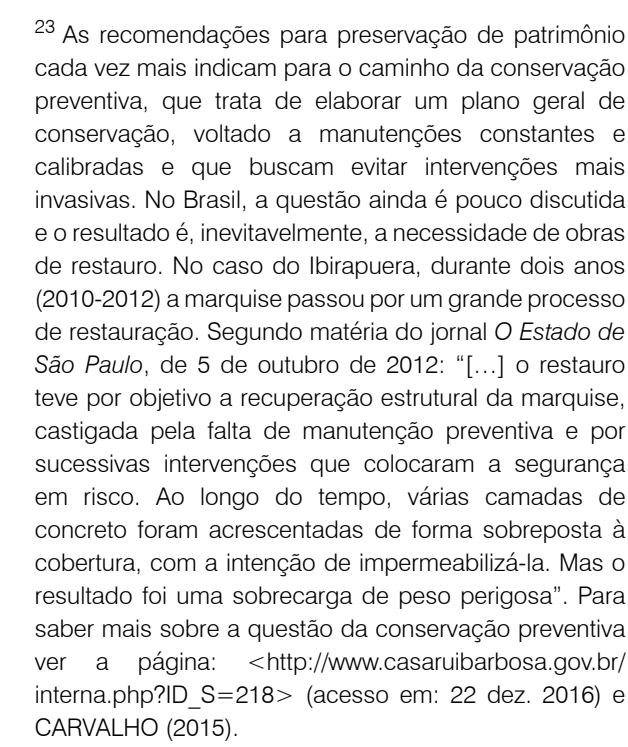

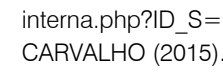




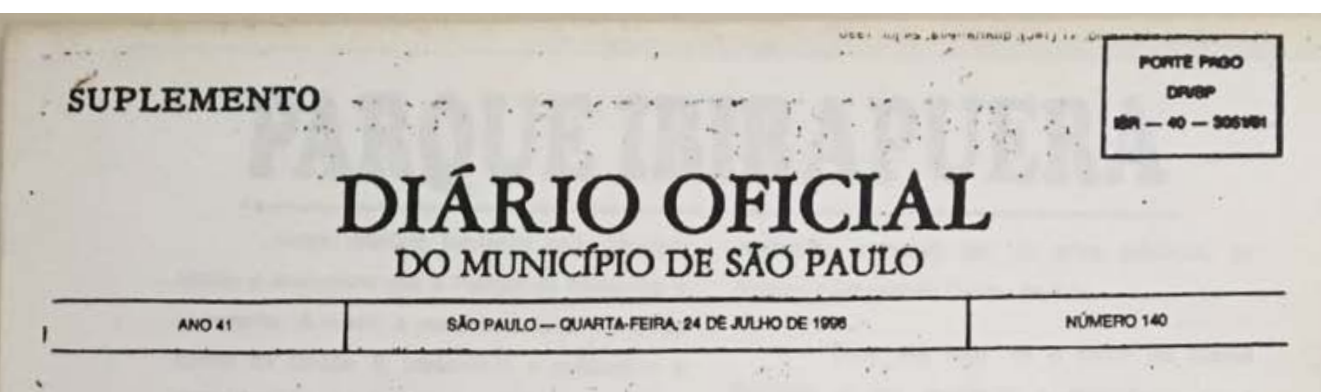

PLANO DIRETOR PARA O PARQUE IBIRAPUERA ELABORADO PELO ARQUITETO OSCAR NIEMEYER.

-1996 -
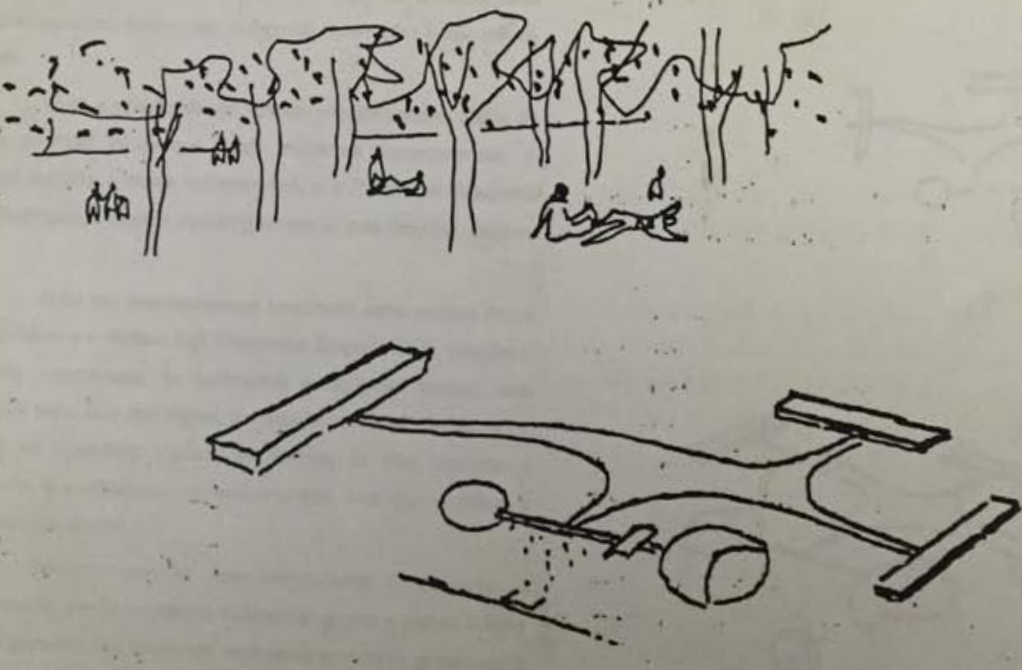

\section{PARQUE IBIRAPUERA}

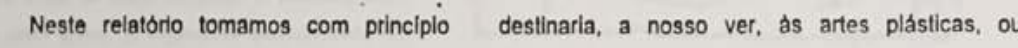

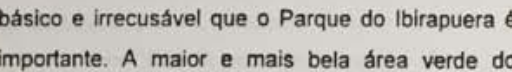
centro da cidade. E preservato o e detende-to
dever do governo e de todosos os seus habitantes dever do govemoe de todos os seus habtian

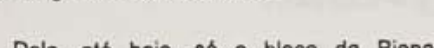

Adotando esse ponto de vista, esper (a)

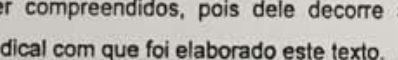
esinteresse pelo assunto. Fora esse bloco, os utros dois edificios continuam sem deffiniça, e as adcal com que foi elaborado este text tarios, pois

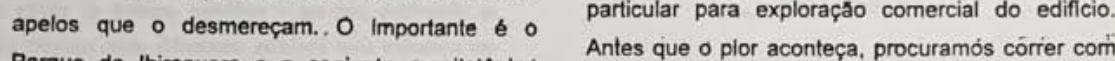

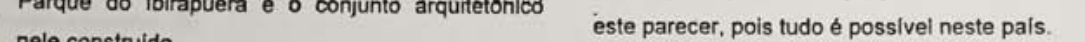

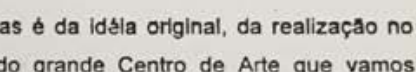

\section{PROJETO}

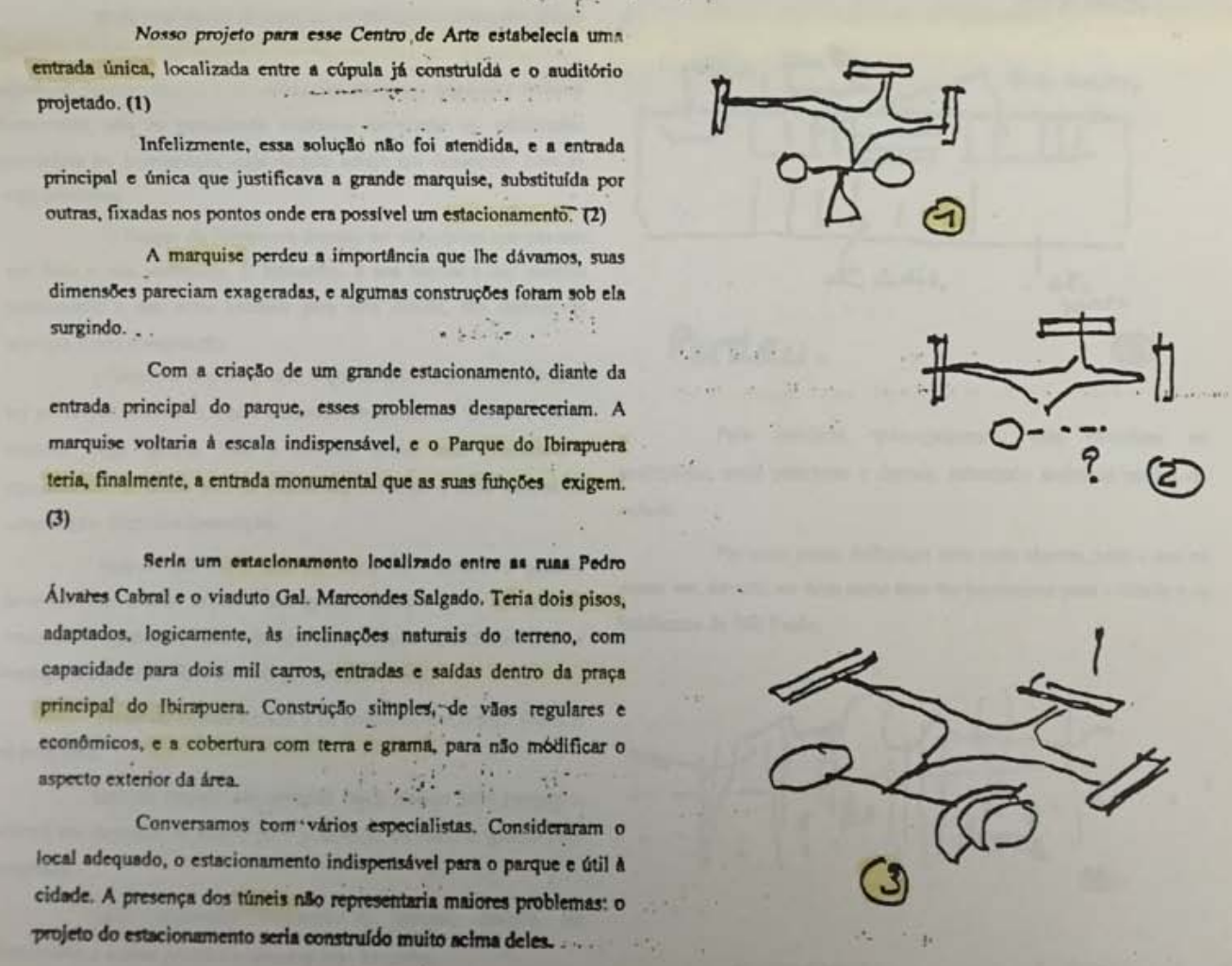




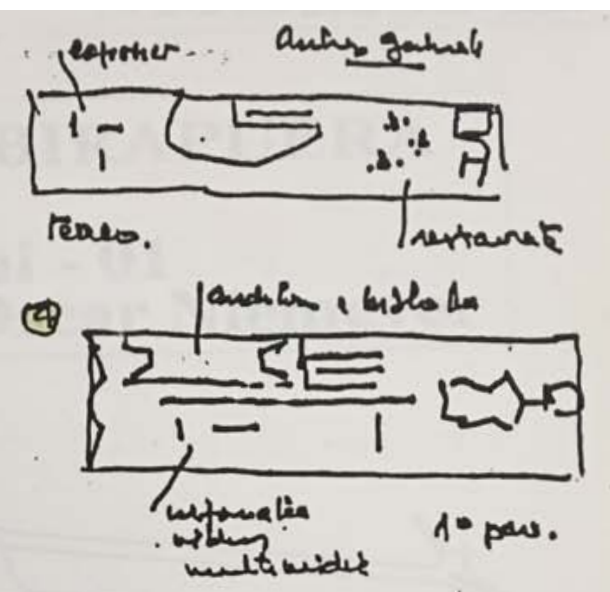

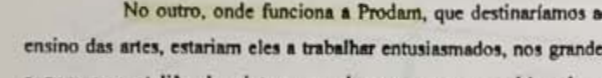

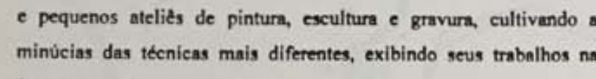

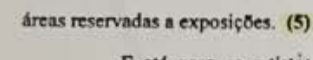

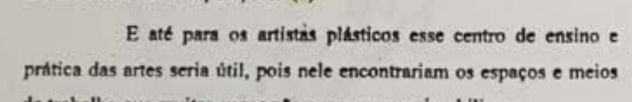

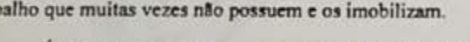

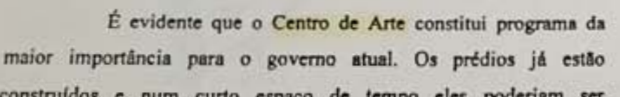

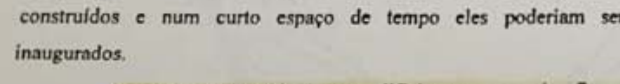

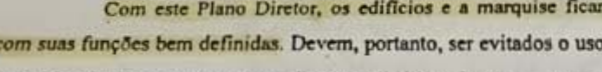

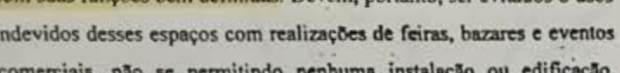

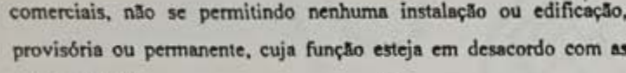
squi previstas.

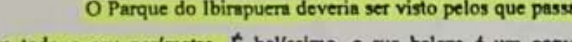

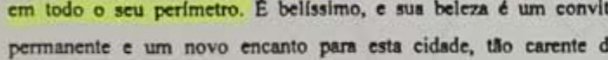

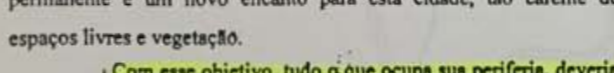

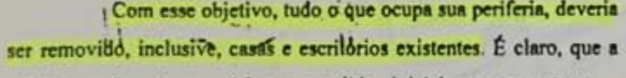
solvesto exige tempo. Mas a mestida inteila que propomos.

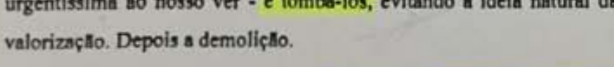

Nossa opiniato ef que as atras de repouso e passerio

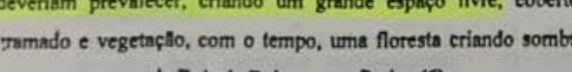

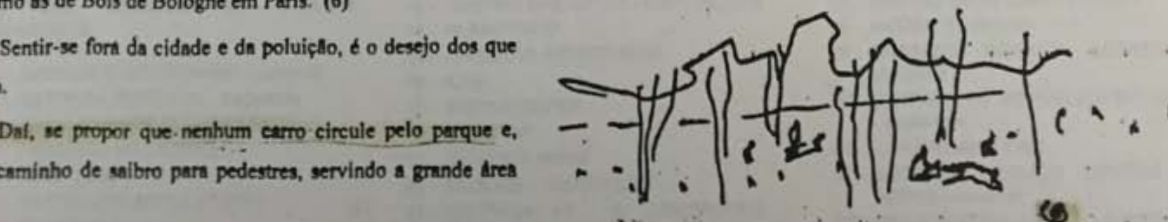
Dar $x$ Thote

\section{emposices}

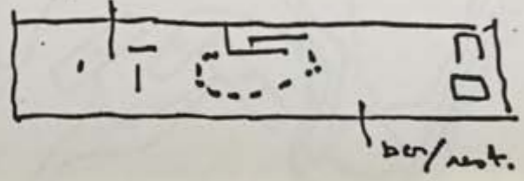

atten, Puthen

LLITE LIIII!

1111,11

Purdau. Exisio. Takises

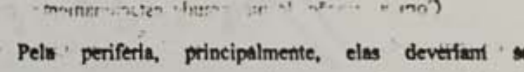

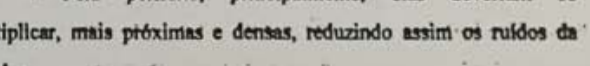

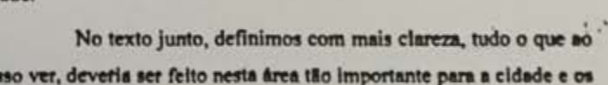

PARQUE IBIRAPUERA

Plano Diretor

Planta Geral - 01

Arquiteto Oscar Niemeyer

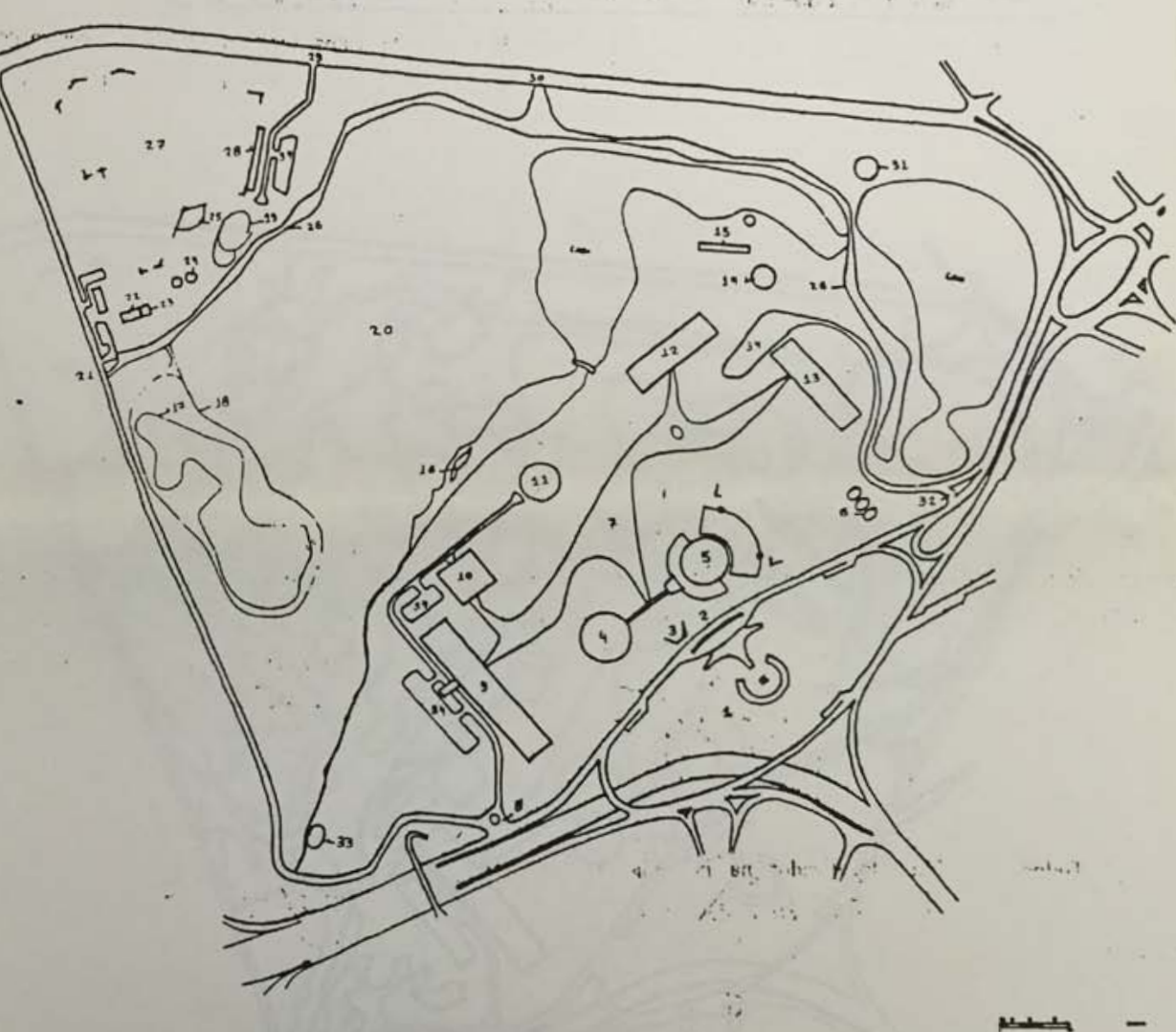

puno aerac

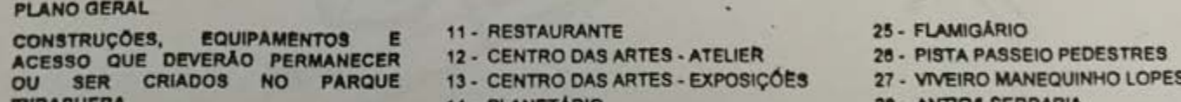

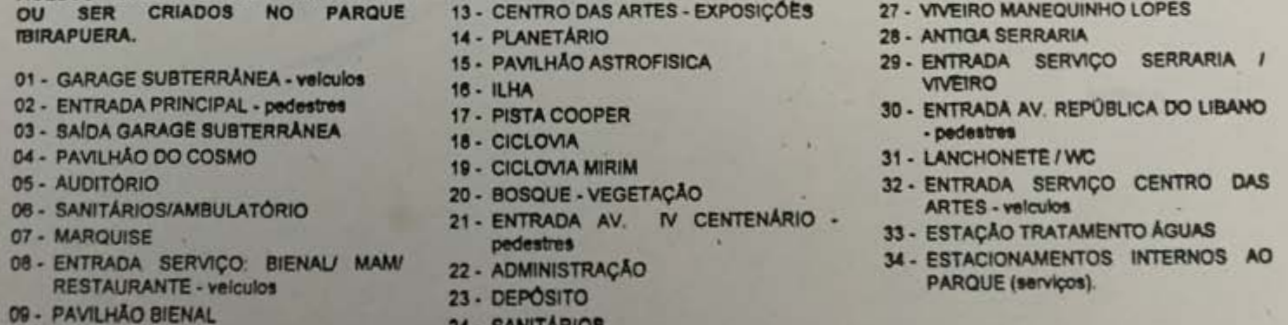


PARQUE IBIRAPUERA

Plano Diretor

Paisagismo - 02

Arquiteto Oscar Niemeyer

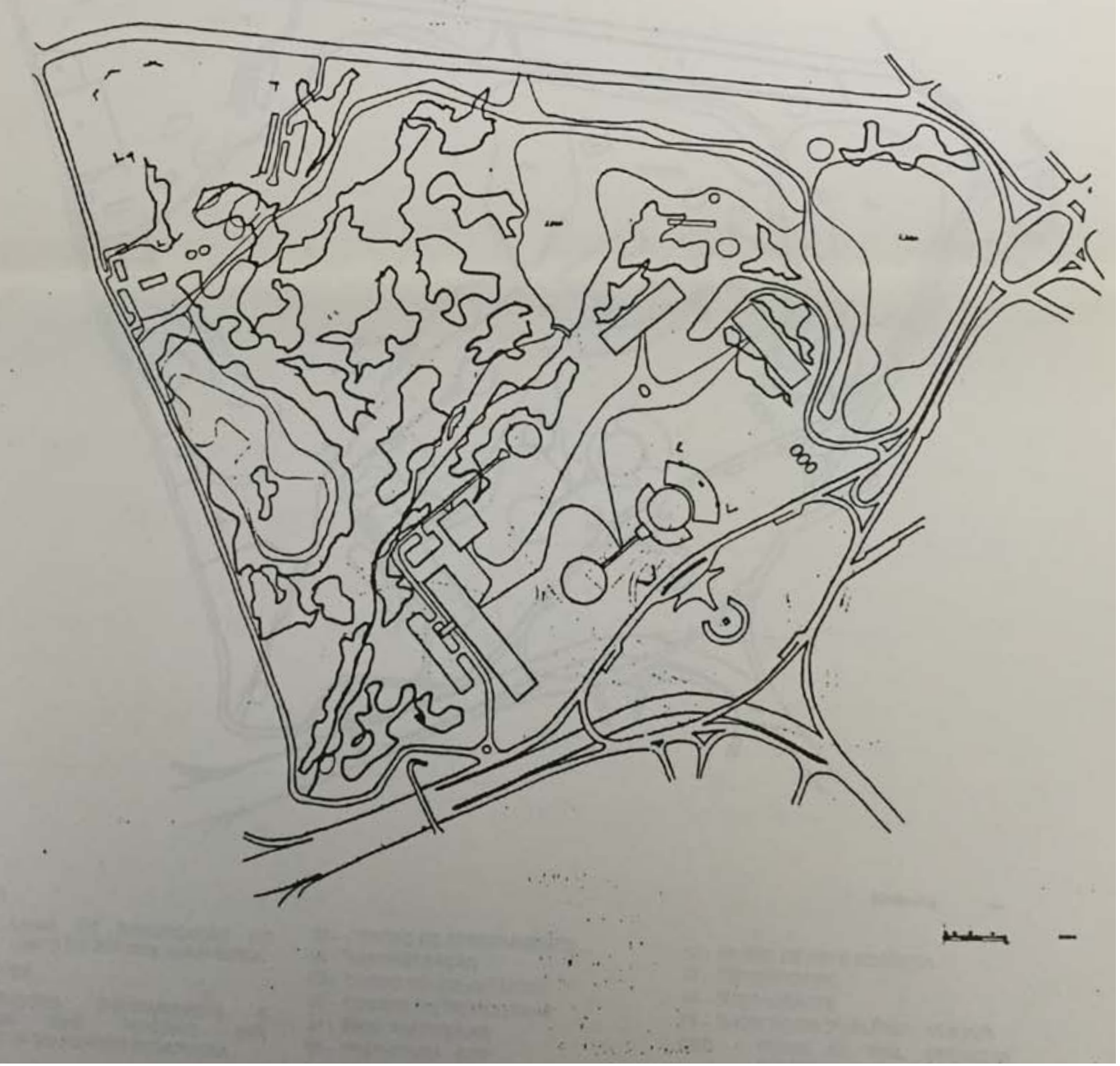

PARQUE IBIRAPUERA

Plano Diretor

Limites e Remoções - 03

Arquiteto Oscar.Niemeyer

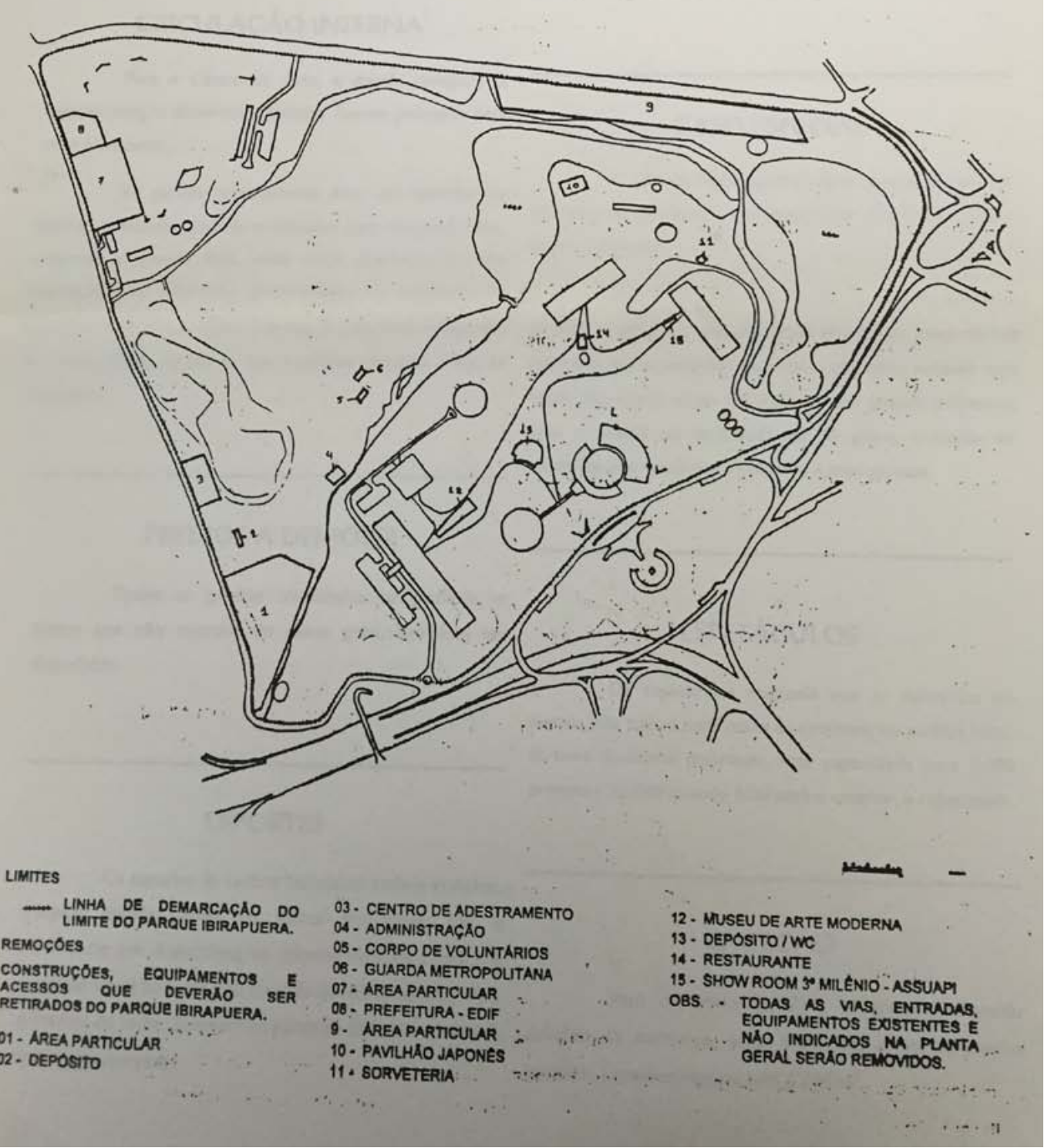

81. Plano Diretor para 0 Parcue lbirapuera, $p 6$ 

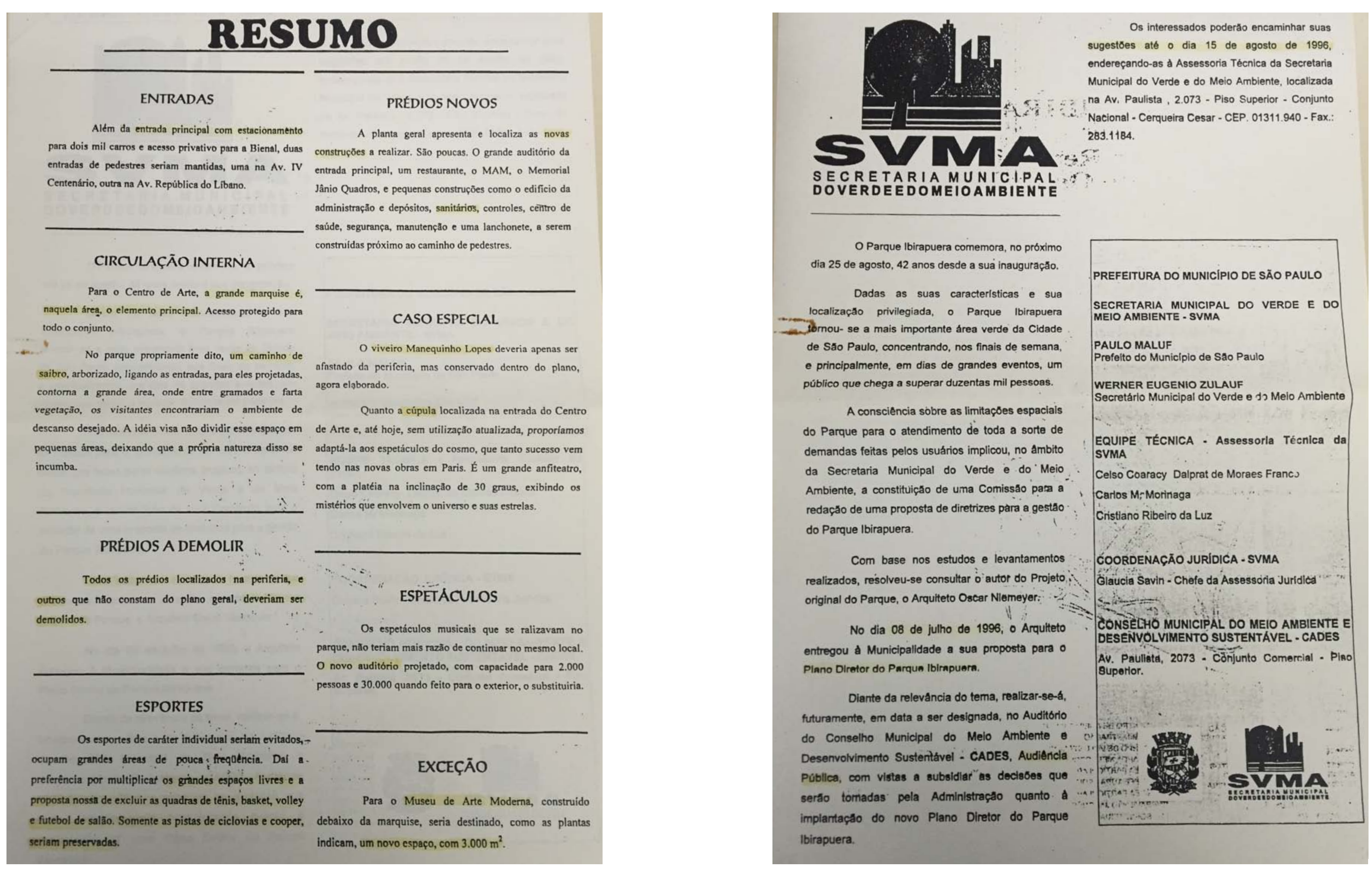


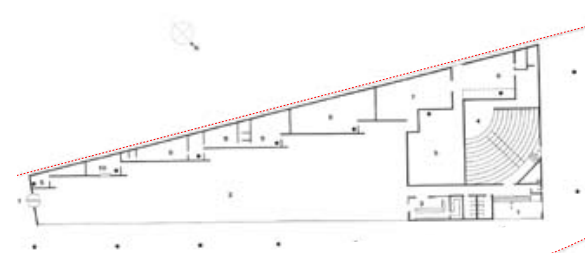

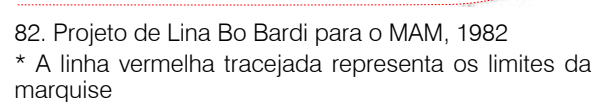

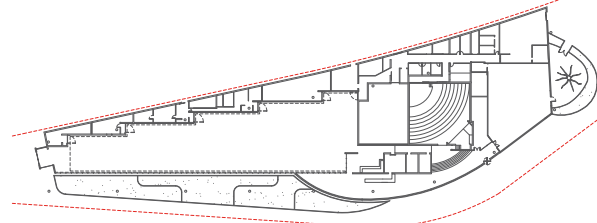

83. Planta atual do MAM
*A linnu vermelha tracejada representa os limites da
marquise

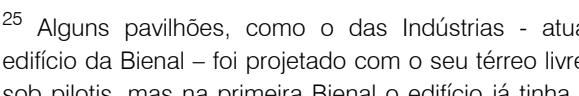
sob pilitis, mas na primeira Bienal o edificio jéa tinha
O MAM, Museu de Arte Moderna, foi implantado sob a marquise, onde existia - Museu de Cera ${ }^{24}$, com projeto de Lina Bo Bardi, André Vainer e Marcelo Ferraz, de 1982. O edifício foi construído no mesmo local em que Bo Bardi montou a exposição Bahia, para a V Bienal de São Paulo: sob a marquise, próxima ao acesso do edifício da Bienal. O espaço do MAM foi sistematicamente ampliado ao longo do tempo, sempre no mesmo local, interferindo no espaço que deveria ser desimpedido de construções e na relação da marquise com o edifício da Bienal, seu principal acesso.

Nos processos do IPHAN há uma extensa troca de correspondências a respeito da exposição da Aranha, de Louise de Bourgeois. O MAM pediu autorização para a exposição temporária no local do antigo Museu do Presépio e não retirou a instalação no fim do prazo. Após diversas comunicaçoes sobre a necessidade de remoçăo da obra e. diante do proposital adiamento por parte do MAM, fol emitido um mandato judicial para a remoção. A negociaçaao pela extensão de prazo visava, evidentemente, a incorporaçáo dessa area ao MAM, a qual fol ber-sucedica. A Aranha está hoje def hilvamente no ao longo dos anos.

Algumas das leituras mais evidentes a respeito da marquise são sobre se tratar de um amplo espaço, completamente aberto para todos os lados. Além disso é a principal conexão entre todos os pavilhões do parque, de forma aberta e franca. A marquise é ocupada de formas variadas e se transforma em função da sua ocupação ao longo de um mesmo dia e nos dias da semana Seguramente, é um dos espaços abertos públicos mais importantes da cidade e permite uma sociabilidade ampla, extraordinária A defesa de preservar a marquise livre de novas construçōes não está, portanto, no argumento da preservação do projeto original mas considera a relevância que ela tem para a compreensão do parque e sua apropriação pelos seus usuários. Já os pavilhões, com seus múltiplos usos - nos últimos anos todos têm se transformado em museus ou em espaços expositivos -, têm caráter diferente, com acesso controlado ${ }^{25}$.

O já citado processo de ocupação da marquise corrompe esses valores de forma brutal e chama atenção o fato de o MAM ter resistido à reorganização. Sua posição na marquise bloqueia a relação com o edifício da Bienal, além de criar um fundo uma parede cega de acesso às áreas administrativas. Além disso, seu programa, mais restrito, não condiz com a proposta essencial da marquise. Em uma das ampliações, fo construído um grande restaurante que se abre visualmente para o parque. Entretanto grande parte das exposições não é visível para os usuários que circulam fora do museu, sob a marquise. Uma vithne que, mais do que uma simples divisão espacial, estabelec uma blindagem para os usuarios do MAM. Considerando o caráter publico da marquise, é necessário destacar que o museu e o restaurante são evidentemente voltados para um público espećf́ico e elitizado ${ }^{26}$. É clara a percepção de que a grande maioria das pessoas que circulam pela marquise enxergam, nos limites físicos do museu, uma barreira. Pode-se argumentar que o programa de um museu é sempre mais restrito. Não se trata de negar essa questão, mas de compreender que esse uso pode perfeitamente ocupar um dos pavilhões, adequados para tal finalidade. Apesar da necessidade de ampliar seus espaços, a direção se recusa a sair do lugar que ocupa atualmente.

Outra discussão a ser feita vem das diretrizes das discussões estabelecidas no campo de preservação de bens culturais: o MAM sob a marquise seria uma intervenção que reflete as diversas temporalidades no parque ou uma adição danosa ao conjunto? Sua remoçao freo pincipio da presenvacăo ca manutença das camadas históricas? Por que o MAM foi a única construção a permanecer sob a marquise?

São questionamentos que dividem opiniões, mas a característica da marquise, como principal elemento aberto, público e articulador de toda a infraestrutura do Ibirapuera, sem fechamentos, sem acessos definidos, é um valor reconhecido e que merece ser preservado. A implantação de um bloco fechado - assim como todos os outros que oram devidamente removidos, sem entrar no mérito de seus programas - interfere sobremaneira na marquise, principalmente na sua articulação com o edifício da Bienal.

Não foram poucas as oportunidades de o MAM ocupar um dos pavilhões e liberar a marquise, mas isso nunca se concretizou. Em 2013, o Secretário da Cultura do ando de Arruda Pereira, a antiga sede da Prodam, dentro do parque, que foi recusado pelo museu².

É curioso ver a manifestação de duas entidades a respeito do tema. O DOCOMOMO se pronuncia com uma leitura da arquitetura sobre a intervenção na marquise:

Inicialmente uma sala de proporções modestas (menos de 400 m²), o MAM ao longo dos últimos anos tem se expandido com a fúria de um desbravador Atualmente o Museu ocupa uma área de aproximadamente $2.000 \mathrm{~m}^{2} \mathrm{~s}$. uma outra área, anteriormente ocupada pelo Museu do Presépio. Esse museu tinha sido transferido da área sob a Marquise em função do Plano Diretor do Parque lbirapuera aprovado em 1996 que preve entre outras acões, a libeção total do espaço da e que preve entre outras açoes, a liberaçāo total do
Marquise tal como projeta Niemeyer, autor do Plano.

Niemeyer também prevê a transferência do MAM para um dos pavihões do Parque que têm hoje usos não compativeis com

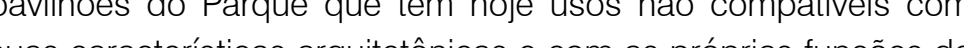
parque.
ETHint an

4. Aranha, de Louise Bougeois

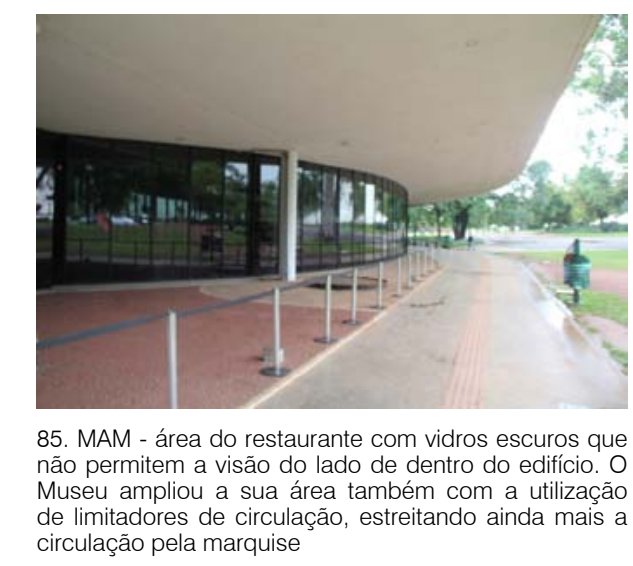

${ }^{26} \mathrm{O}$ restaurante, a grande vititine voltadad para o parque
das esculturas cobra aproximadamente R\$100,00 por pessoa (aproximadame
o caratier elitista do local

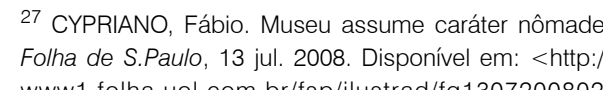

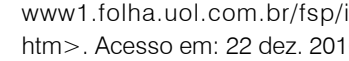




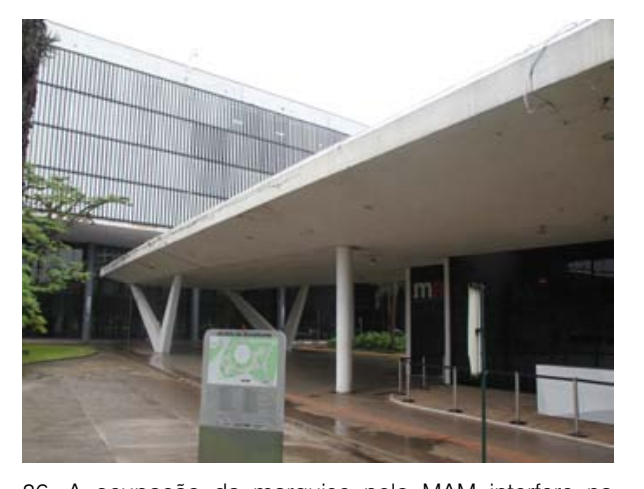

86. A ocupacáa da marquise pelo MAM interfere na
relaçăa da Maracuise com ao acesso da Bienal

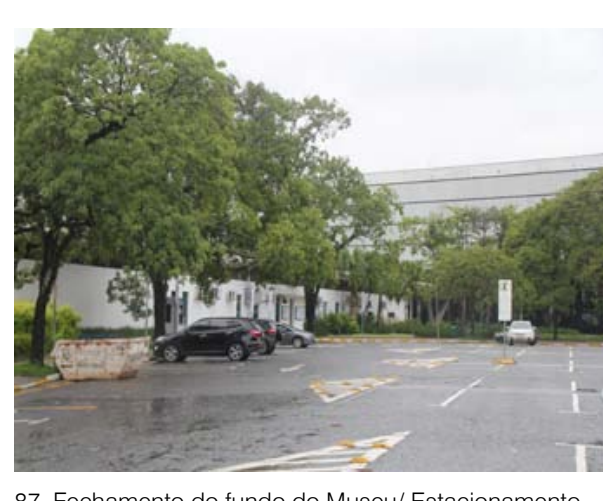

${ }^{28}$ Mirthes Baffi. Docomomo Săo Paulo. 29 Pedro Cury, presidente do IAB. Boletim 10 set./out.
1998.
No entanto, a solicitação do MAM vem na contramão do Plano, inviabilizando a recuperação do Parque e principalmente da Marquise, caso aceita.

Já o Instituto de Arquitetos do Brasil (IAB) apresenta um texto confuso, que se

A possível utilização de outra parte da marquise do Parque lbirapuera pelo Museu de Arte Moderna/MAM nos dá a oportunidade de refletir sobre a questão do tombamento de edifícios públicos de valor histórico e sobre seus desdobramentos. O IAB sempre se posicionou na defesa da arquitetura e na valorização do trabalho do arquiteto - e é com essa visão que enfocamos esta polêmica Não cabe discutir a origem da ocupação pelo MAM de parte da marquise e nem o seu mérito, esimverticar se esse uso está causando prejuízo para o conjunto arquitetônico.

Um museu, na área da cultura, constitui uma atividade nobre, e MAM pelas suas características e pelas atividades que vem de senvolvendo, é hoje um dos mais importantes museus da cidade com um acervo artístico da maior expressividade, prestando um senviço inestimável para a educação artística da população principalmente, as crianças. Além disso, o espaço ocupado pelo MAM é o que apresenta melhor estado de conservação em relação a outras áreas da marquise.

Dá a decisão do IAB de apoiar a sua permanência no Parque lbirapuera. O MAM lá está há muito tempo, virou tradicão e ja acostumamos com sua presença: esse é o seu lugar Em segunda instância, apoiamos sua permanência no espaço que ocupa hoje, desde que em caráter provisório, mas com o compromisso de não medir esforços para que esse provisório não se transforme em definitivo, se não pelas razões expostas, pelo simples fato de que o MAM merece um espacomais adequado e mais condizente com a sua importância. ${ }^{29}$

O texto de Mirthes Baffi é enfático e claro quanto ao dano causado à marquise

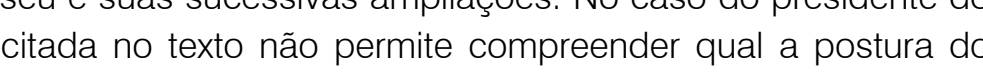
órgão. Por um lado, defende veementemente a permanência, por outro diz se tratar de algo provisório

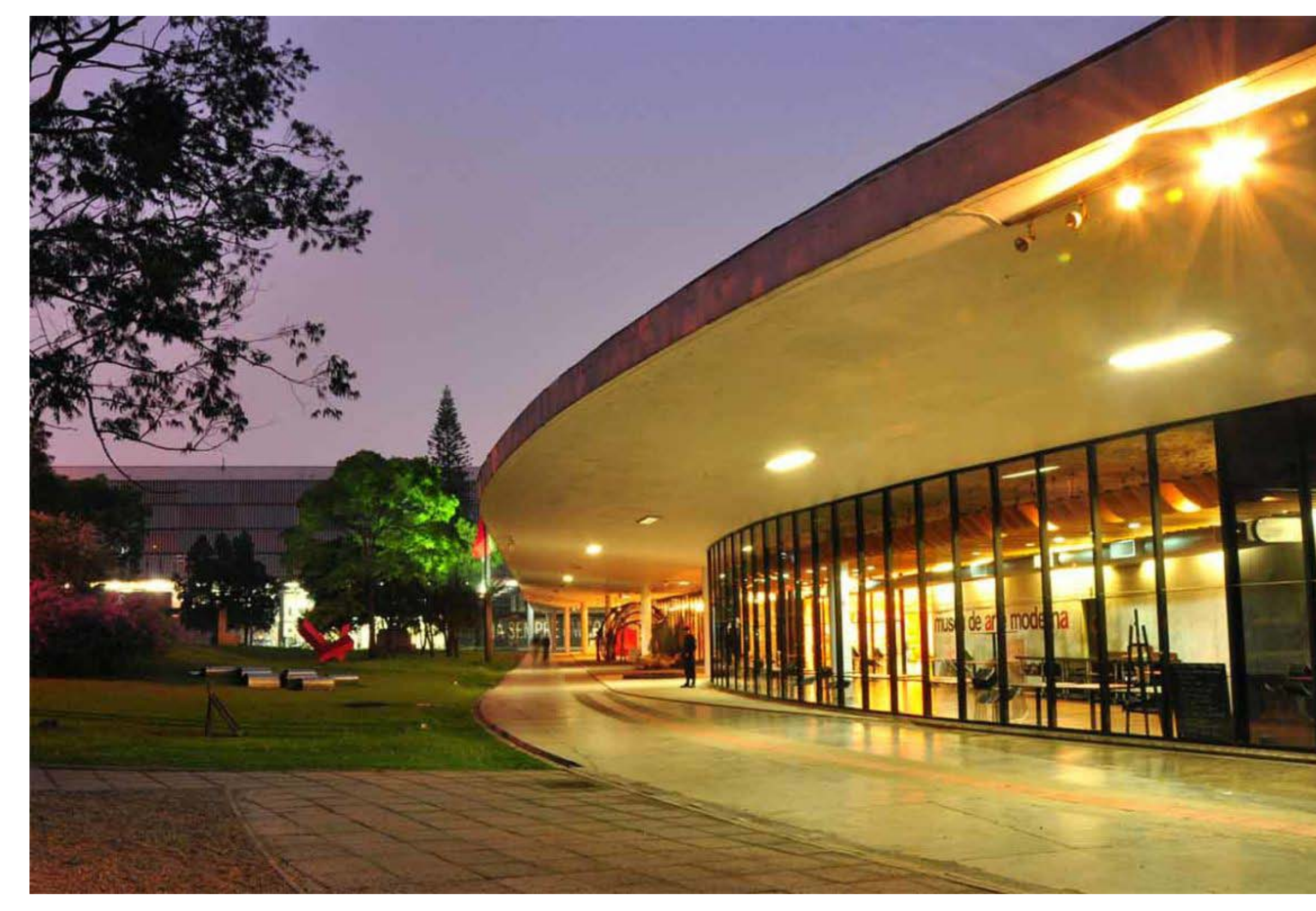

88. MAM 
Sob a alegação do bom estado de conservação, usado como argumento para a sua permanência, cabe destacar que a administração do MAM é independente da do parque, tendo financiamento privado. A boa conservação do espaço não parece ser um argumento convincente, já que a discussão está na preservação da qualidade espacial e ambiental da marquise.

Cabe questionar se uma das razões para a permanência da única construção após a remoção das demais adições não tenha sido, mais do que o próprio MAM, o fato não totalmente explicitado de se tratar de um projeto de Lina Bo Bardi. Essa é uma estratégia comum quando se trata de patrimônio. Se o edificio não suscita maiores interesses de preservação por sua arquitetura, a autoria acaba por ser o argumento irrefutável para a sua permanência.

Em 1998, a Secretaria de Negócios Jurídicos da Prefeitura de São Paulo assina um Termo de Permissão de Uso a Título Precário e Gratuito com o MAM, permitindo sua expansão sob a marquise. 0 memorial descritivo do projeto de ampliação praticamente não cita a localização do museu e uma eventual intenção de se relacionar com o parque A única menção, que é evidentemente protocolar, é a intenção de que "[...] nos finais de semana está previsto o uso deste atelier para atividades de arte-educação com as famílias que frequentam o Parque" ${ }^{\text {30 }}$

Segundo Gurian (2014, p. 103):

Por mais que se consolide como um reconhecido endereço da arte paulistana, esse volume construido se apresenta formalmente como uma barreira fisica e visual à permeabilidade do espaço, além de obstruir a entrada principal do público na sede da Bienal A criação de uma área administrativa e de serviços, em alvenaria, ao fundo, voltada para o estacionamento, paralelo ao pavilhão da Bienal e ao longo da cobertura, bloqueou a transparência. Mesmo a fachada frontal, materializada em cristal e remetendo a um desejável caráter diáfano, acaba se alterando constantemente em função do conteúdo ali exposto. O acesso principal, pela própria marquise, se abre a um jardim de esculturas ao ar livre e deixa um passeio abrigado entre a edificação da Bienal e o pavilhão das Artes, a Oca.

A Fundação Niemeyer, em carta endereçada ao DOCOMOMO, se posiciona na orientação de Niemeyer que entende a ocupação da marquise como "[...] solução lamentável, nunca aceita"31. O documento é assinado por Ana Lucia Niemeyer de Medeiros, diretora executiva da Fundação e neta de Oscar Niemeyer.

Segundo Lina Bo Bardi " [....] o terreiro já tem uma história (apesar de que, se eu fosse o Niemeyer, já teria pedido a demolição de tudo aquilo)" (FERRAZ, 1996, p. 256).

Por fim, tratar a questão como sendo exclusivamente sobre a preservação de patrimônio cultural amesquinha a discussão. Apesar de juridicamente legal, o MAM interfere no cotidiano do parque, cria um fundo que, não por coincidência, limita o espaço do estacionamento. Seguramente a sua implantação em local mais adequado, tanto para o parque, como para o museu, traria maior qualidade em todos os sentidos.

\section{Pavilhão Lucas Nogueira Garcez - Oca}

Para as comemorações dos 500 anos do Descobrimento do Brasil, em 2000, oi realizada uma grande exposição itinerante, Brasil 500 Anos, que em São Paulo fol instalada nos pavilhões do Parque Ibirapuera.

O Pavilhão de Exposições Lucas Nogueira Garcez, a Oca, como é popularmente conhecido, tinha abrigado o Museu da Aeronáutica e do Folclore e ficou fechado por mais de uma década.

Nesse grande evento receberia a exposição indígena. Como não apresentava, na ocasião, boas condições de uso, o momento se mostrou propício para uma intervenção de restauro e modernização do edifício.

Paulo Mendes da Rocha (1928) foi contratado para desenvolver um projeto para a Oca ${ }^{32}$. No memorial, o arquiteto deixa claro seu respeito pela obra que considera " $[\ldots]$.
um dos mais belos espaços expositivos do mundo, revelando no seu interior, por onde se penetra por uma pequena fresta, uma inesperada espacialidade, uma volumetria imprevista, silenciosa e agradável" (ROCHA, 1998).

Dessa forma, justifica sua intervenção ao considerar que o pavilhão "É uma das obras mais límpidas e singelamente monumentais de Niemeyer. E já de meio século passado. Fizemos tudo para conservá-la intacta. Como no desenho original do arquiteto" (ROCHA, 1998).

Internamente, a lógica construtiva e a espacialidade do edifício, apesar das intervenções, são mantidas na sua integridade. O espaço, de extrema beleza, é resgatauestões de ordem pragmática, quando o edifício era utilizado como museu.

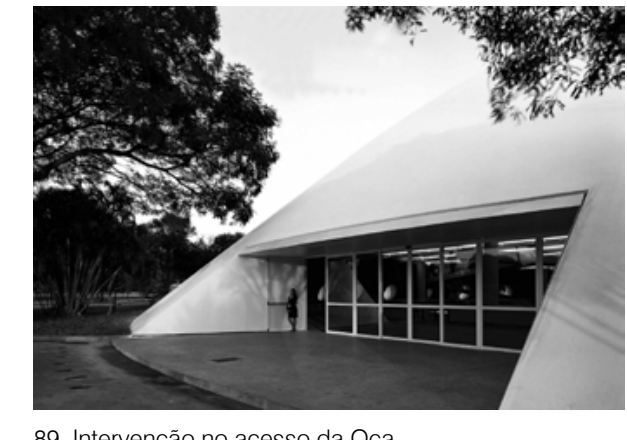

99. Intevennăă no acesso da Oca

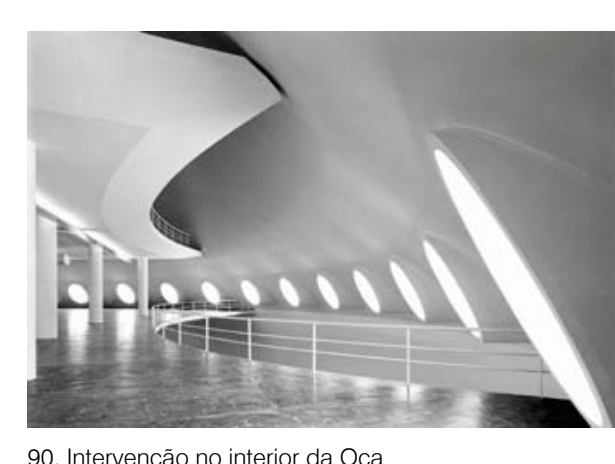

31 Citacăo de Oscar Niemeyer na réferida carta da
Fundagăa Niemeyer ao DOCOMOMO - Acervo IPHAN ${ }^{32}$ Em parceria com MMBB Arquitetos 
Apesar da qualidade do projeto realizado, cabe discutir a decisão de contracontrário. Paulo Mendes da Rocha é seguramente um dos arquitetos brasiliros mais importantes do século XX ${ }^{33}$. Entretanto, nesse caso específico, Niemeyer foi consultado sobre a escolha e afirmou que, tratando-se de Mendes da Rocha, não haveria nenhuma restrição ao trabalho $0^{34}$

Observando atentamente esses casos, que terão enormes desdobramentos no que será discutido a seguir, pode-se ver a autoridade e poder de decisão que se pretende atribuir ao arquiteto-autor do projeto do parque. No caso da ampliação do edifíci da Bienal, segundo o próprio Niemeyer, ninguem, a não ser ele e sua equipe, poderia intervir na obra do parque. Com relação à Oca, não sendo sua equipe, sua autorização é decisiva.

Outra questão que se apresenta é o indeferimento do projeto para a Bienal sem nem ao menos entrar no mérito do projeto. Nesse caso, negar a possibilidade de ampliação do edifício poderia, eventualmente, inviabilizar ou restringir o seu uso. Se a intervenção fosse a possibilidade de uso mais intenso do conjunto, sem interferir negativamente na percepção do parque, a diretriz da resolucão, de impedir acréscimo de área construída poderia ser, pela sua rigidez, mais lesiva do que preservadora.

Nesse caso, como em alguns outros, é possível abordar o projeto conforme uma das questôes apresentadas no capitulo anterior. Niemeyer propõe uma intervenção absolutanten te contempoñ na: compreenclo o valor reconhecido no conjunto e necessidade de ampliação e atualização. Faz uma proposta que deveria ser discutida nesse sentido.

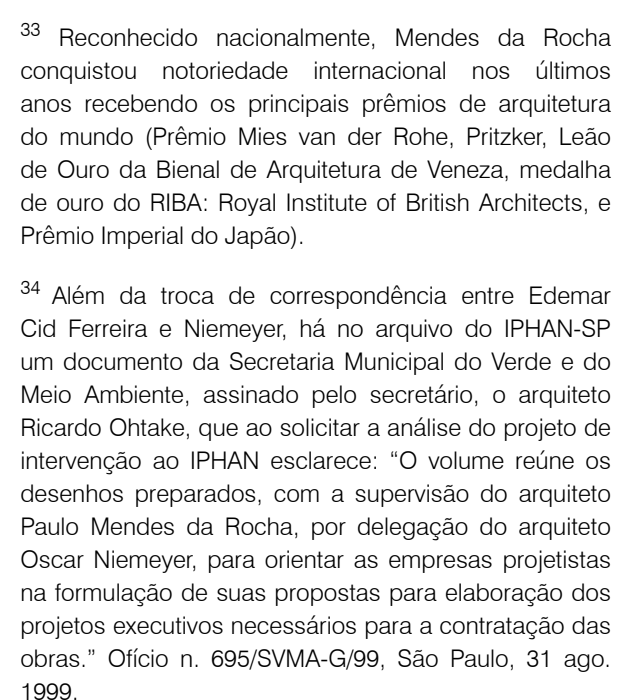

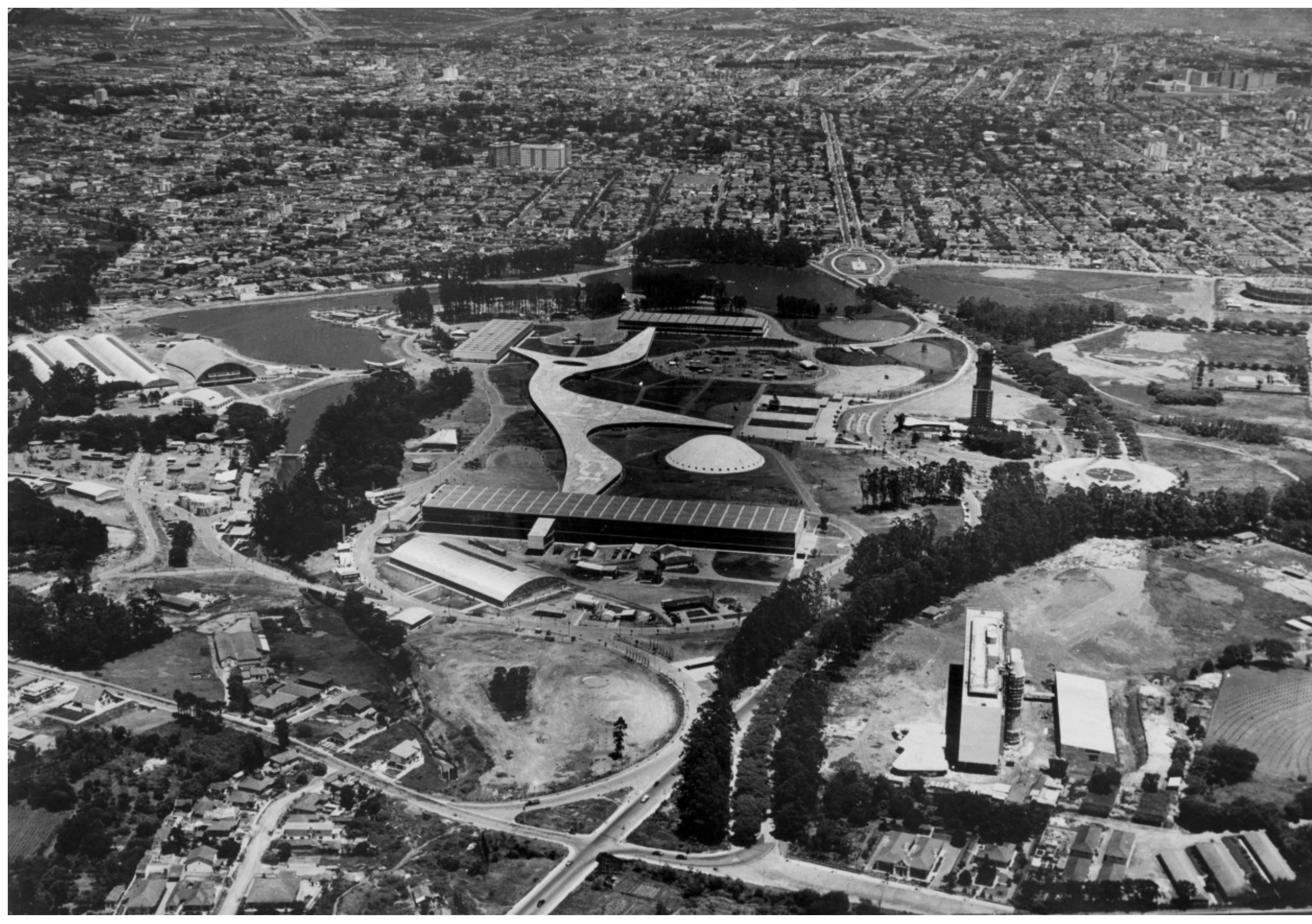

91. Vista aérea da construçäo do Parcue Ibirapuera nos anos 1950 


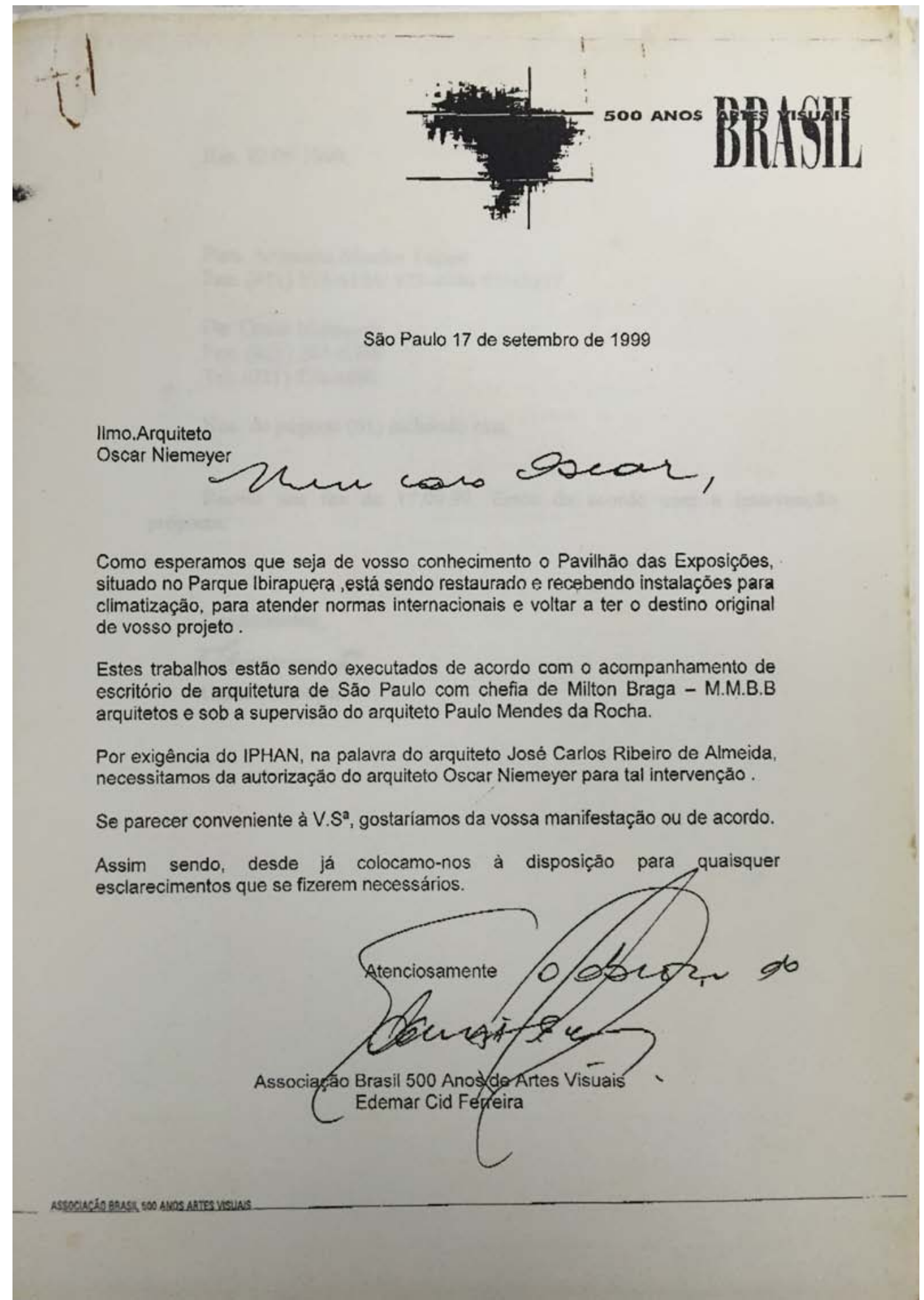

Rio, 22.09.1999.

Para: Arquiteta Monica Taguin

Fax: (011) 573-6184/ 573-4396/573-5157

De: Oscar Niemeyer

Fax: (021) $267-638$
Tel: (021) $523-4890$

Nos. de páginas (01) incluindo esta.

Recebi seu fax de 17.09.99. Estou de acordo com a intervenção proposta.

$$
\text { Oscar Niemeyer }
$$


A construção desse novo equipamento cultural tem para a atual Administração Municipal uma pluralidade de significados que deve ser destacada

a. Integrar-se às ações empreendidas no sentido de frear e reverter o processo de deterioração sofrido há anos pelo Parque, através da recuperaçấo de seus espaços e equipamentos, do resgate de seu carater publico e finalmente, de novos polos indutores de sua valorização.

b. Criar um espaço adequado para a permanente demanda de espetáculos musicais no Parque Ibirapuera, oferecendo a um só tempo, um equipamento para eventos em ambiente fechado e a céu aberto, assim disciplinado e estabelecendo a escala apropriada para tais atividades.

\section{c. Resgatar e acentuar a vocação cultural do Parque}

d. Entregar à cidade, na oportunidade de 50 anos do Parque, a conclusão de suas instalações visto ter este ficado desde a sua abertura sem a esplanada de entrada principal e a construção do segundo de dois volumes destinados a marcá-la.

e. Estabelecer um novo paradigma na relação de parceria entre poder público e iniciativa privada na cidade de São Paulo, uma vez que todos os custos necessários à construção do novo auditório seráa assumilios pela empresa de teleforla móvel TiM, com todas as garantias que assegurem o caráter público do espaço. f. Marcar os festejos dos 450 anos de fundação da cidade mediante a entrega de um novo marco paisagístico. (CONPRESP, 2003, p. 3)

O projeto apresentado implanta o auditório em local diferente da disposição original e tem sua arquitetura completamente alterada. Além disso, é proposta uma nova marquise de interligação entre o edifício da Oca e o novo auditório, com a demolição de 40 metros da marquise existente a fim de adequá-la à nova proposta.

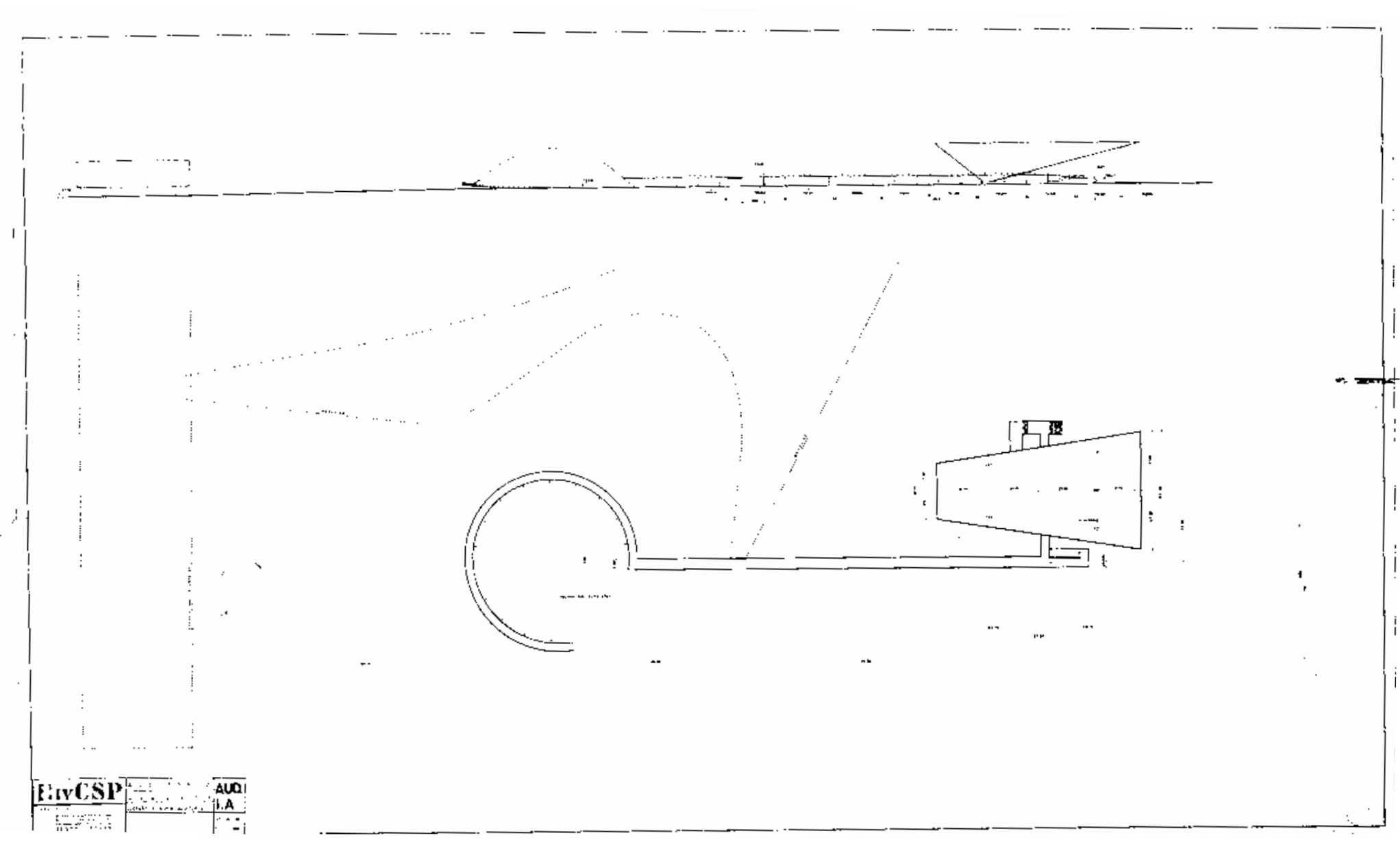




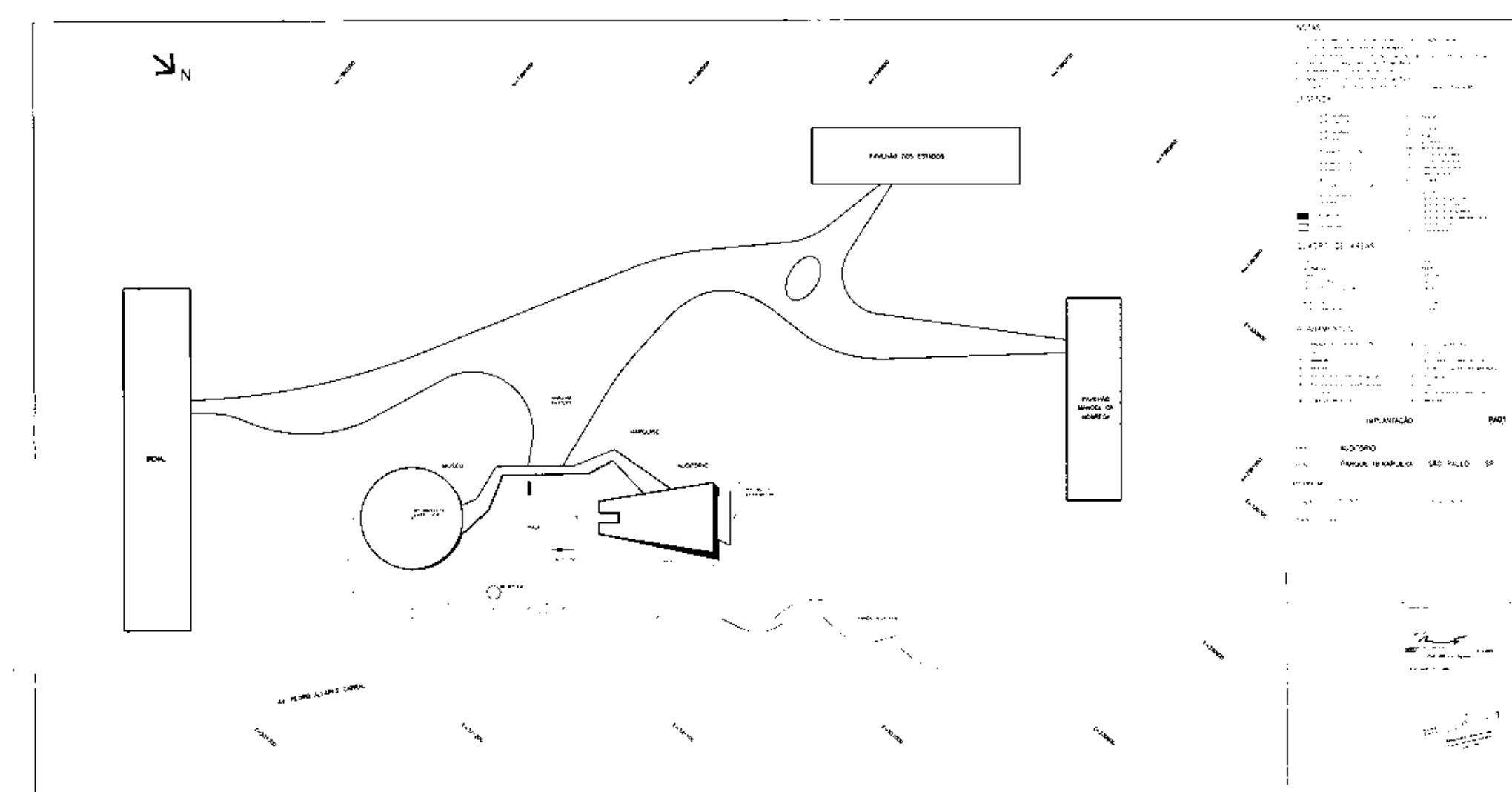

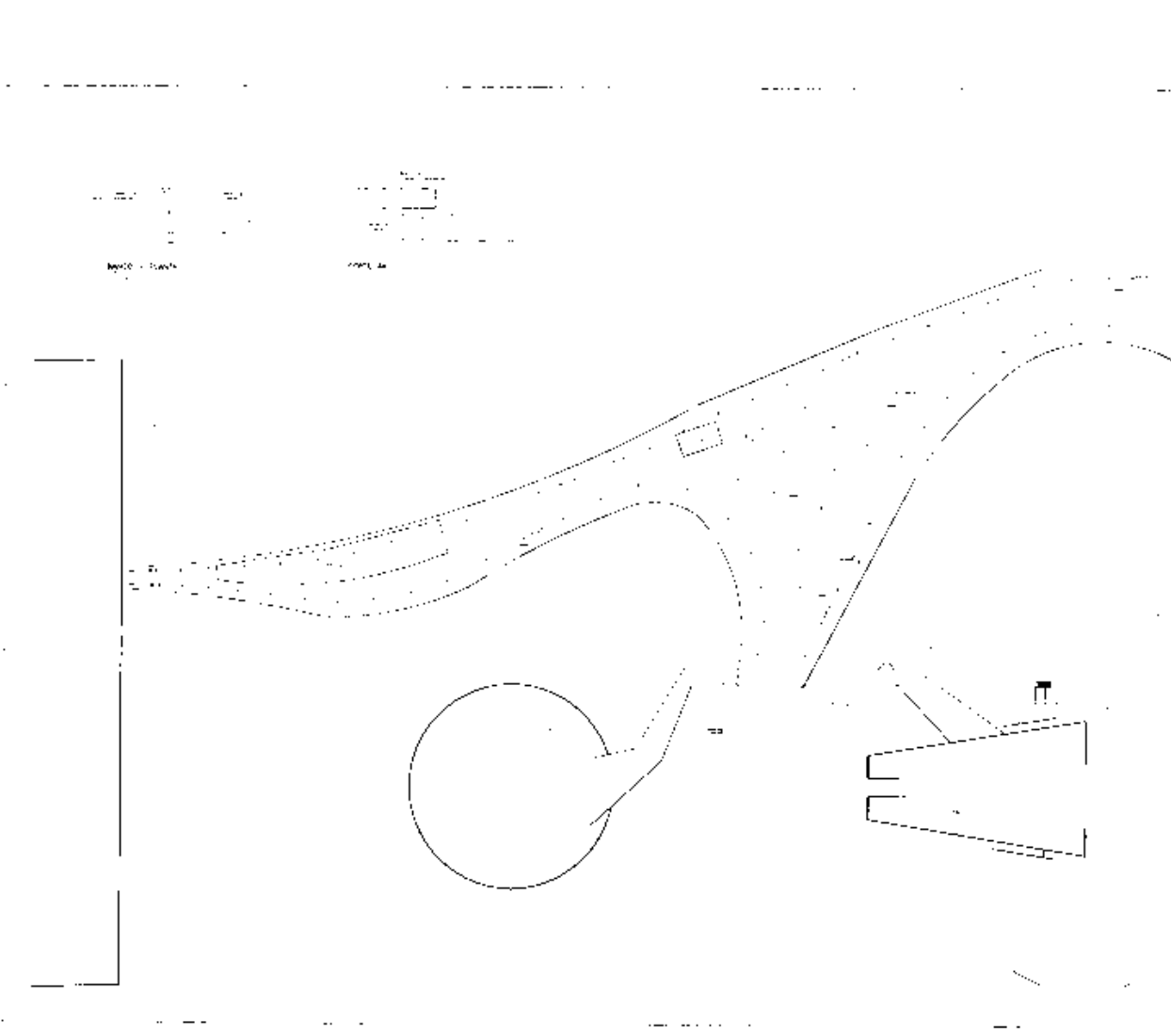




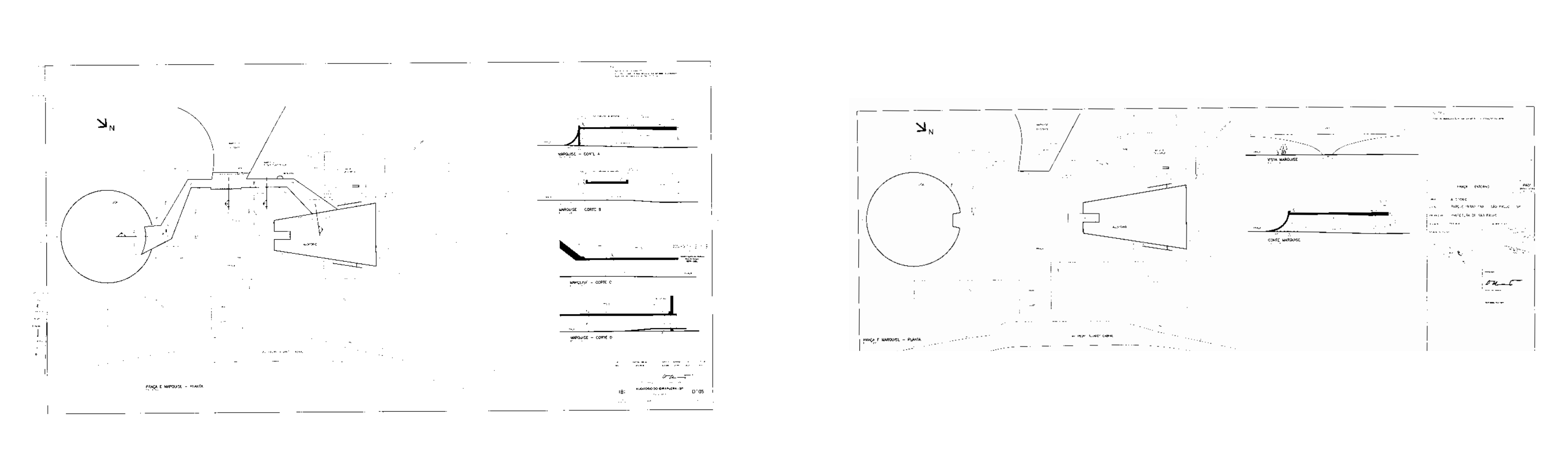




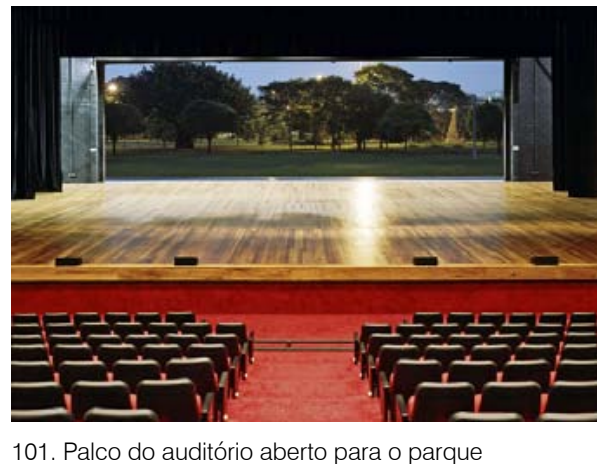

101. Palco do auditióri aberto para o parque

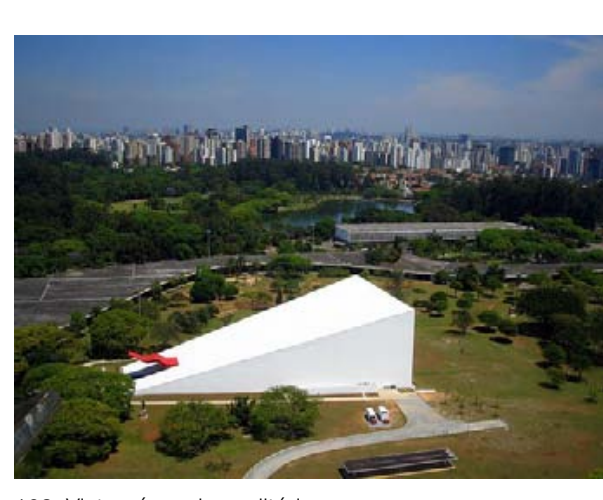

102. Vista aérea do auditorio
Essa nova proposta vai ao encontro da percepção de que o tombamento não deve congelar um projeto no tempo. Mesmo se tratando do arquiteto-autor do projeto original, ao abordá-lo para uma nova intervençäo cinquenta anos mais tarde, Niemeyer propõe alterações, mas mantém a lógica do original.

A contradição que se apresenta é sobre a argumentação pautada sempre na ideia de completamento do projeto original. Estabelece uma perspectiva de trabalho em andamento que não representa a situação real. A obra de 1954 foi finalizada e, da form como foi construída, reconhecida nacional e internacionalmente pela sua qualidade. Não significa que não possa receber acréscimos ou sofrer alteraçōes.

A construção do auditório está evidentemente referenciada no projeto original, como num plano. Trata, entretanto, de um novo projeto, adequado às demandas do momento de seu desenvolvimento, no início dos anos 2000. Desde que respeitados os valores reconhecidos no conjunto, essa proposta não fere, obrigatoriamente, a preservação do Parque Ibirapuera, que seria a leitura apresentada pela resolução do CONDEPHAAT. Deve ser lida como uma nova intervenção. É curioso observar que o site do auditório com a deliberada intenção de estabelecer um projeto de continuidade de 1954 a 2005, informa a respeito do prédio:

\section{Autor do projeto: Oscar Niemeyer \\ Data do projeto: 1954}

Conclusão da obra: $2005^{3}$

Essa informação, além de imprecisa, leva à interpretação equivocada de se tratar de um projeto que se iniciou nos anos 1950 e foi conclú́da em 2005.

Construído o auditório, argumenta-se, com o respaldo das colocações de Niemeyer, que finalmente o parque está completo. Será que significa dizer que não se pode fazer mais nenhuma intervenção ou construção? Parece claro que não, mas é uma posição que divide opiniôes. O parque pode ainda sofrer numerosas interferências, inclusive a construçấo de novos edifícios, desde que respeitados os valores reconhecidos. Em relação à resolução do CONDEPHAAT, a aprovação do auditorio pode muito bem ser utilizada como um precedente para novas construções, por tudo o que foi exposto até aqui.

Além disso, parece que a ideia de completar o projeto de Niemeyer está diretamente relacionada com as questões discutidas no primeiro capítulo, que trata da trata-se de uma grande aça publicitária tanto para a empresa patrocinadora como para a cidade de São Paulo, pois alegava-se que o projeto original proposto nos anos 38 Auditorio Ibirapuera. Disponivel em: <http://mm:
auditorioibirapuera.com. brhlistoricol>. Acesso em: 22 1950 por Niemeyer finalmente estaria completo.
No CONDEPHAAT, a mesma arquiteta que recusou o edifício proposto em 1994, Lucilena Whitaker Melo Bastos, amparada na resolucão de tombamento que impedia o aumento de área construída e a diminuição de área verde permeável, justifica a aprovação do novo auditório:

2. [...] para os que não conhecem o projeto, fica inexplicável a visão de um braço da Grande Marquise que termina abruptamente no vazio e que não conduz a lugar nenhum. Para os que o conhecem fica a aspiração de ver preenchida a lacuna existente.

Entendemos, pois, que a possibilidade apresentada de construção do auditório obedecendo a um projeto do próprio Niemeyer é perfeitamente justa e benvinda. Porém, só pode ser aceita pelo fato de estar contida na proposta arquitetônica original.

Quanto à contradição apontada pelo Conselho ao emitirmos parecer favorável à aprovação do auditório, acreditamos que poderia ser vista como uma contradição aparente. Esclarecemos.

Neste mesmo processo o pedido inicial é de ampliação do PaviIhão da Bienal, projeto do arquiteto Niemeyer.

Nossa posição em 1994 foi contrária à aprovação e assim seria mantida caso o projeto fosse apresentado hoje, independentemente de quem fosse o autor. Isto porque estaria em desacordo com a resolução de tombamento do Parque e não configuraria nenhuma edificação prevista no projeto original. (CONDEPHAAT, 1994, p. 66)

Observando atentamente o processo integral de tombamento do conjunto do parque, no CONDEPHAAT, não há nenhum tipo de menção ao projeto original ou ao auditório não construído. O reconhecimento do Ibirapuera se dá pelo seu conjunto edificado. Há, claramente, uma contradição nos pareceres da técnica do CONDEPHAAT, que confunde o tombamento do parque e suas edificações com as documentaçōes do projeto original. A ideia de que um projeto, passados cinquenta anos de sua concepcão, ainda estaria absolutamente pronto para ser construído não condiz com a boa prática profissional e a resposta a essa questão é dada pelo próprio Niemeyer quando apresenta uma proposta que altera completamente o desenho original por ele mesmo desenhado, cinquenta anos antes. 
Fica também evidente que não há discussão sobre o parque, seu valor reco-

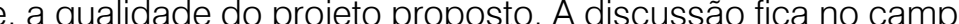
burocrático e, do ponto de vista legal, é bastante discutível, já que a resolução não abre exceções em relação à ampliação das áreas construídas ${ }^{39}$.

Em 2003, o CONDEPHAAT se pronuncia oficialmente por meio do já citado texto de Ulpiano Bezerra de Menezes (CONDEPHAAT, 1994, p. 96) ${ }^{40}$, no qual se apresenta uma importante leitura do conjunto do parque e o qualifica como "paisagens associáveis", já que é

"[...] área verde, mas muitíssimo mais que isso, pois integra a área verde a um conjunto monumental que dá novos significados aos elementos naturais como deles recebe também valores novos. Esta interaçâo fecundante, no bitapuera, tem expraurdinária qualidade, reconhecida no mundo inteiro" (CONDEPHAAT, 1994 p. 96).

A respeito do auditório, esclarece que seria impossível qualquer manifestação na resolução, que tratasse de sua preservação, um edifício inexistente no momento do tombamento, mas entende que a implantação do novo projeto: "[...] traria um equilíbrio que potenciaria com genial eficácia o conjunto já edificado e tombado, o que fica patente en desenhos comparativos do Arquiteto Oscar Nieney e fotograflas exibidas abundantemente pela imprensa" (CONDEPHAAT, 1994, p. 98)

Por fim, questiona a ação do órgão de preservação e a resolução de tombamento:

[...] seria um contrassenso entender que a preservação impediria o acréscimo de atributos culturais, para cartoriamente congelar uma situação no momento em que o poder público assumiu a proteção do bem. 0 estado não pode exercer tal proteção para fins meramente documentais e burocráticos, mas para aumentar a fruição cultural dos cidadãos - fruição em que as obras da natureza e as obras do homem interagem de forma qualificada. Quando esta fruição pode ser dilatada, o Estado não tem justificativa legítima para manter-se, impávido, como o guardião fundamentalista do status quo (CONDEPHAAT, 1994, P. 98)
Menezes também argumenta a respeito da aprovação do projeto, por se tratar de obra de Oscar Niemeyer:

[...] cinquenta anos depois, cria-se a oportunidade - inesperada e excepcional, lembre-se sempre - para o mesmo arquiteto, no pleno vigor de seu extraordinário poder criativo, retomar o mesmo elo, completando o projeto original e incorporando as novas geraçoes e seus novos sentidos aos significados e valores a

emanavam do projeto original. (CONDEPHAAT, 1994, p. 99).

Apesar do argumento pela implantação do auditório sob o olhar da qualidade do parque e de sua preservação ser pertinente, conforme colocado no capítulo anterior, considerar a autoria como um fator para aprovação de uma intervenção é decisão discutivel, caso o autor não reconheça na sua obra os valores atribuídos pela sociedade. Corre-se o risco de perdas irreparáveis.

\section{Marquise}

No mesmo momento em que projeta o novo auditório, Niemeyer propõe o corte da marquise do parque. $\mathrm{O}$ arquiteto considerava essa "ponta" uma aberração, ja que ela ficou sem sentido quando o auditório não foi construído nos anos 1950. Uma ponta solta no meio da praça. Seguindo o partido do projeto original, a implantação do auditório seria acompanhada de uma marquise transversa que uniria a Oca, o auditório e a marquise. Com a alteração da implantação do novo auditório e a intenção de unir os dois edifícios por uma nova marquise, Niemeyer propõe o corte, alegando ser a situação ideal para corrigir a falha da construção do parque.

Construir uma nova marquise para unir os edifícios não parece ser nenhuma ação danosa ao conjunto, pelo contrário. Negar essa possibilidade, do ponto de vista do projeto e da preservação do parque, dificilmente encontraria embasamento técnico e teórico para sua defesa. Como o próprio Niemeyer coloca a implantação do novo auditório renova a dinâmica do parque, sem perda de suas virtudes e ainda evidencia os tempos de intervenção. Já o corte da marquise em 40 metros, que foi defendido por algumas pessoas como uma "pequena mutilação", deve ser discutido com maior rigor. Evidentemente, perante a difmensáo total da marquise, a área removida representa um percentual extremamente pequeno. Entretanto, não parece que uma leitura aritmética da quantidade de metros quadrados removidos seja uma argumentação que efetivamente reflita a discussão.

As questões que se colocam, portanto, são de outra ordem, partindo sempre do princípio de que a proposta não era o complemento do projeto original: era mesmo

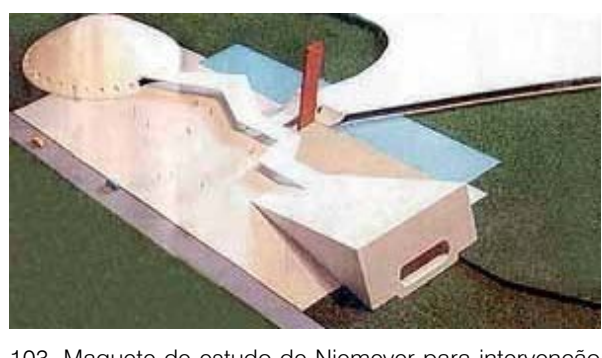

103. Maquete
na marauise
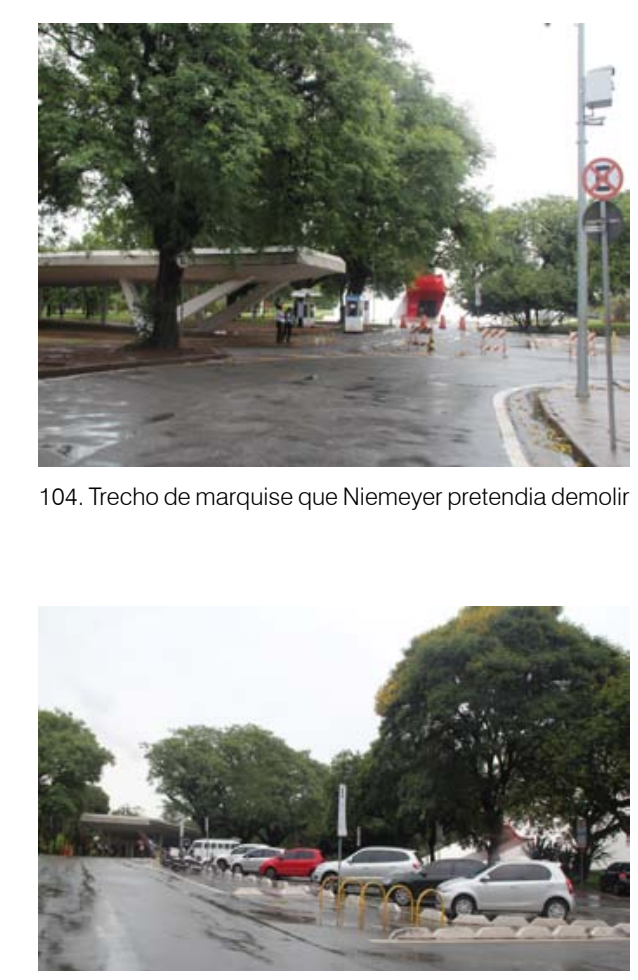

105. Estacionamento no aceso do parque entre a Oca 
necessária e única possibilidade, a implantação dessa nova marquise, de tal forma que exigisse a demolição dos 40 metros da existente? Não poderia haver outra solução que fosse mais cuidadosa? Por outro lado, o corte proposto é de fato uma mutilação danosa? Ou sua execução traria incrementos ao parque que justificariam tal ação? Além disso, e voltando ao tema central deste trabalho: não fosse Oscar Niemeyer o arquiteto que tivesse proposto o corte, essa discussão teria avançado? Ou seria rapidamente descartada? Caso Niemeyer tivesse proposto rigorosamente o desenho do projeto original, seria aceitável?

O argumento usado sobre a ponta que acaba no vazio parece ser bastante frágil. Uma leitura do projeto original levanta, do ponto de vista da geometria do conjunto uma questão importante. A ponta da marquise junto à Oca era a única que não se conectava diretamente a um edificio. Dessa ponta, Niemeyer propôs uma nova marquise reta, que se diferencia da organicidade da grande marquise e configurava a praça de acesso principal. Ou seja, originalmente, a marquise tinha esse desenho que era uma exceção no conjunto do parque. A ideia de cortar a marquise parece ser, também, um desejo de corrigir algo do projeto que o arquiteto-autor identificou como problemático. Algo que se aproxima das propo que o alletle-Duc de voltar no tempo e compreender o que o arquiteto faria, mas, nesse caso, trata-se do próprio autor revendo sua obra.

É evidente também que Niemeyer usa de seu prestígio para impor a nova solução. O próprio arquiteto apresenta várias versões do projeto, mas não se submeteu à exigência de trabalhar com a marquise sem realizar o corte. Propôs diversos tipos de "arremate" para essa ponta e desenhos da marquise de interligação entre os prédios.

Niemeyer é enfático quanto ao seu desejo e se coloca de forma bastante impositiva perante a discussão que se apresenta, o que acaba por inviabilizar o seu novo projeto. Escreve uma carta dirigida aos presidentes dos três orgãos de preservação de patrimônio cultural evidenciando sua indignação e reafirmando sua autoridade de "autor do projeto".

A discussão é colocada sempre nos termos do "autor que irá completar sua obra", e raras vezes se discute a qualidade do projeto propriamente dito.

Em um primeiro momento, o CONPRESP autoriza a construção do auditório, mas estabelece uma diretriz para as áreas externas:

[...] o projeto das áreas externas deverá ser apresentado posteriormente, inclusive com a nova marquise de interligação. Como já foi manifestado verbalmente deverá ser respeitada integralmente a configuração va marquise atual, que é tombada e nãa poderá sofrer nenhuma forma de mutilação. (CONPRESP 2003, P. 21) 41 $^{4}$
Em 2004, com o auditório já em obras, a prefeitura entra com o pedido de aprovação da ligação da marquise do Parque Ibirapuera ao novo auditório e à Oca.

Nesse momento, Niemeyer se pronuncia em relação à aprovação de seu projeto:

Será que o Parque Ibirapuera, o centro de artes mais importante da América Latina, merece tanto desprezo? Será que o Estado de São Paulo, o mais rico deste país, não tem condiçōes de o construir e vai deixar aquela cúpula que desenhei solta, como coisa inútil e secundária, sem o auditório que com ela compõe a entrada do parque? Será que a inveja, a ignorância ou coisa pior explicam o que está ocorrendo? Será que o problema apresentado da redução íntima da área permeável, que a modificação dos caminhos internos do parque vai mais que compensar, justifica tamanha celeuma obrigando-me a participar nesse ambiente de tanta mediocridade? $?^{42}$

O processo no CONPRESP apresenta vários pareceres de técnicos, todos contrários à demolição do trecho da marquise, dos quais podem ser destacados os seguintes trechos:

A licença para a construção do referido projeto foi dada de modo excepcional porque se alegou, na época, tratar-se de complemento de obra inacabada. (CONPRESP, 2004, p. 9)

[...] a ideia de vê-la seccionada parece desprovida de razão certamente causará comoção na população da cidade; o corte projetado elimina os pilares em V e a parte frontal da Marquise fazendo com que ela perca a sua proporção e criando um problema compositivo pois ela, ao invés de escoar até a ponta, passa a terminar em um ponto intermediário mais largo e que cria um problema de difícil solução, o que obrigou o escritório projetista a "selar" a entrada principal com uma parede que obstrui a passagem e a visão.

A permanência do braço que aponta para a entrada, convidando o visitante a ingressar em seu espaço e no espaço do Parque não pode ser considerada como uma interferência numa praça que chega 50 anos depois. A convivência é perfeitamente possível interessante. (CONPRESP, 2004, p. 11)

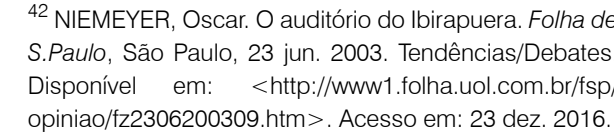

'A Assinado por Clara D'Alambert (20 jul. 2004 ) ${ }^{44}$ Assinadoo por Mirthes I. S. Baffi, diretora da divisäo de
preservacăa DPH/SMC (25 ago. 2004). 
O olhar modesto de nosso mestre para a sua obra o faz externar tal interferência com a naturalidade de quem interfere num espaço comum. Comum, sim, porque naturalmente assimilado e vivenciado pelos usuários do PARQUE; comum, porque o caracteriza tão singularmente, que the permite identidade. É caro ao patrimônio da forma como está. Lamentamos, mestre, com todo o respeito, discordar deste seu novo olhar. (CONPRESP, 2004, p. 5) ${ }^{45}$

[...] justificativas com base em um direito do autor, que não podem ser aplicadas tal como estão sendo: ninguém nega ao autor e sua equipe a propriedade intelectual do projeto que deu origem à construçâo da marquise que ai esta $[. .$.$] ....no entanto, a brecha$ (decorrente de omissao legal sobre o assunto) à possibilidade do autor alterar a sua obra não pode se sobrepor às limitações do tombamento. (CONPRESP, 2004, p. 36)

A conselheira Monica Junqueira de Camargo pede vistas do processo e, antes de elaborar o seu parecer, realiza uma visita ao escritório de Oscar Niemeyer, no Rio de Janeiro. Nessa ocasião, a arquiteta relata que decidiu "[...] ir ao Rio de Janeiro para ouvir do próprio arquiteto suas explicações sobre o projeto, para uma avaliação mais fundamentada da proposta" (CONPRESP, 2004, p. 38) ${ }^{47}$ e prossegue:

[...] num primeiro momento mostrou-se muito defensivo, alegando uma incompreensão por parte dos paulistas sobre o seu projeto. Ao apresentar suas justificativas, Oscar Niemeyer foi revendo suas ideias e disse que não estava mais satisfeito com que havia proposto e que me enviaria um novo croquis. (CONPRESP, 2004 p. 38)

No seu parecer, Camargo coloca questões essenciais para a compreensão do 45 Processo 2004-0.154.355-9 CONPRESP fi. 5 , assinado
por Sueli de Bem, arcuiteta-chefie da Seçăo de Técnica

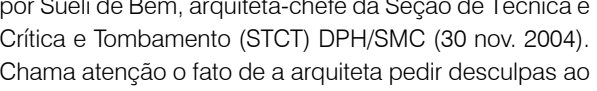

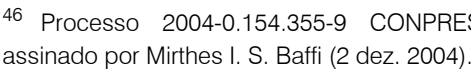
${ }^{47}$ Processo 2004-0.154.355-9 CONPRESP ff. 38 (7 noy gridade física do entorno, bem como das edificaçōes a sua volta. É da natureza criativa de Oscar Niemeyer a liberdade plástica, a superação de obstáculos, os desafios. Imaginar que ele refizesse o mesmo projeto 50 anos depois ou que ele se contivesse diante de um projeto de sua própria autoria, seria desconhecer a sua trajetória. Do ponto de vista do Patrimônio Histórico a contratação de Oscar Niemeyer foi uma atitude, sem dúvida, corajosa, porém, correr riscos é condição primordial para se avançar. (CONPRESP. 2004, p. 39)

Além dos valores já bastante reconhecidos do parque e da marquise, levanta ainda a importância da obra no conjunto de projetos de Niemeyer por uma tipologia que, a partir do final dos anos 1950, já não é mais utilizada nos novos projetos

A própria marquise, um forte elemento na identificação de sua arquitetura, será aos poucos abandonada, sendo praticamente deixada de lado em 1956. Fato esse que fortalece a condição de excepcionalidade desse patrimônio. A marquise do Ibirapuera é um dos melhores exemplos dessa tipologia - percurso abrigado entre edifícios - e uma importante experiência no seu processo de construção da forma. (CONPRESP, 2004, p. 39)

Por fim, ao se posicionar favorável ao projeto, conclui:

Entendo que mesmo com a subtração de $40 \mathrm{~m}$ da marquise, a sua integridade, enquanto objeto arquitetônico, permanecerá inalterada. A antiga marquise não só continuará perfeitamente reconhecível enquanto tal como ganhará notoriedade ao integrar e participar da conformação do novo espaço. O elemento de apoio se harmoniza com as proporções existentes e constitui um registro da invejável lucidez deste arquiteto que aos 96 anos ainda está a nos surpreender. Seu instinto criativo que beira à compulsão nos faz admirá-lo não só pelo muito que já fez mas por tudo o que ainda pode vir a fazer. (CONPRESP, 2004, p. 40). 
Um ato a um só tempo mutilante e generoso: corta-lhe um pedaço, que diante da nova configuração espacial passa a ser uma intromissão e generosamente devolve-hne um ousado apoio escultơrico, que passa a cumprir o papel de um marco, transformando uma ponta desgarada num ousado portal de acesso à marquise. A ponta, que diante da náo conclusăo do projeto original, ficou solta, como que à espera de algum elemento que the desse sentido, assume pelo novo desenho um papel especial na configuração do conjunto arquitetônico. Uma recompensa pelos anos de espera. (CONPRESP, 2004, p. 40)

Na defesa da preservação da marquise com sua configuração original, o arquiteto José Eduardo de Assis Lefevre, então presidente do CONPRESP, escreve um texto intitulado "Marquise do Ibirapuera. Onde está o equívoco?". Uma resposta às questões colocadas acima e à argumentação feita pelo arquiteto Oscar Niemeyer para as alterações do projeto.

Inicia a argumentação deixando claro sua opinião sobre a intervenção do próprio autor em sua obra: "[... o artista é dono absoluto de sua obra? Picasso poderia desfigurar Guernica?" "LEFEVRE, 2005). Náo se trata de desmerecer a produção e a opinião do arquiteto, "[...] figura exponencial da arquitetura brasileira do século XX" pelo contrário, Lefevre defende a manutençao de sua obra nas suas diferentes fases e critica o fato de o projeto ter sido aprovado pelo Departamento de Pattimônio Histórico do Município de São Paulo, sem passar pelo CONPRES

Comparando o projeto original do parque e o do novo auditório, conclui sua argumentação afirmando que há um:

[...] equívoco apontado pelo arquiteto Oscar Niemeyer de que a ponta da marquise fica no meio da grande esplanada de entrada Se houvesse tal equivoco ele estaria presente no projeto de 1953 o que náo ocorre, na realidade. Sm, pols a grande e magnifica outro caráter. (LEFEVRE, 2005)

É com base no "Parecer a respeito das intervenções nas áreas externas do auditorio do Parque Ibirapuera" redigido pelo representante da SEMPLA (Secretaria Municipal de Planejamento, Orçamento e Gestão), o arquiteto José Geraldo Martins de argumentação se dá, principalmente, sob o ponto de vista do reconhecimento de seu valor e da preservaçáo de sua integridade. Cita Vilanova Artigas ao explicar que sua posição trata da "estética":

[...] mas é no seu desenho que se inventa uma forma surpreendente e por ele é que desponta mais do que arrojada e inovadora solução formal, a estética para esse momento da nossa História. [...] suas formas se resolvem numa inagem perfeita que contém outro surpreendente aspecto a se notar: é para ser apreendida por quem a vê do nível do solo e, simultaneamente, para que seja contemplada desde o ponto de vista superior, em planta (ou como se diria, de avião) numa confusão de espaço e tempo própria de quem quer absorvê-la de todas as maneiras e de uma só vez, tão próprio do período que se sucederia e não apenas de um único ponto de vista central, como no barroco por exemplo. (CONPRESP, 2004, p. 44)

Em 2006, é lançado o livro Oscar Niemeyer: a marquise e o projeto original do Parque Ibirapuera, organizado por Cecilia Scharlach. São poucos textos e muitas imagens que mostram o projeto original do parque, o auditório novo já construído e as questôes sobre a marquise.

Chama atenção o texto apresentado por Emanoel Araújo (In SCHARLACH, 2006, p. 12), então Secretário Municipal de Cultura que defende o projeto de Niemeyer para a marquise.

E por que não se respeita um pedido tão normal e lógico como esse? Por que se congela um projeto inacabado como o do Parque Ibirapuera e se os toleram desvios de função de seu projeto original? $\mathrm{O}$ que quer $\mathrm{O}$ arquiteto? Apenas fazer uma praça onde a própria marquise não ultrapasse o espaço do Auditório, de sua própria autoria. Essa tâo maltratada marquise do Parque Ibirapuera, pedindo socorro, tomada por infiltraçóes e rachaduras, com seu piso em estado lamentável, consumido pelas pistas de com seu piso em estado lamentável, consumido pelas pistas de marquise, são apenas 40 a serem demolidos, e uma bifurcacão de marquise, são apenas 40 a serem demolidos, e uma bifurcação a chegar à OCA a ao Auditório recém-inaugurado, o que reintegraria o projeto original. 

de fato.

Por que os conceitos e as práticas associadas à conservação preservação e defesa do Patrimônio Histórico no Brasil são tão retrógrados?

Mesmo com a aprovação da construção do auditório, a decisão final do Conselho foi contrária à intervenção na marquise, o que gerou um processo do Ministério Público Estadual contra o CONPRESP, como será discutido mais adiante.

O auditório, construído há mais de uma década, tem intensa programação, incluindo escola de música. Foi rapidamente absorvido pela sociedade paulistana. Já no que diz respeito à marquise, apesar de encerrado, o tema ainda gera controvérsias. São muitas as falas no sentido de não ser legítimo, por parte do CONPRESP, impedir Niemeyer de qualquer ação no parque, obra de sua autoria.

Olhando exclusivamente para a proposta, é possível abordá-la a partir de uma argumentação em dois pontos separados. O primeiro diz respeito à possibilidade de conectar Oca, auditorío e marquise a partir de um percurso coberto por uma marquise. Náo parece ser uma questáo prejudicial ao parque e seus edificios e, alem de ser uma leitura contemporânea do partido original do parque, traria uma condição de conforto aos usuários. O segundo, a necessidade de, para fazer essa conexão, demolir um pedaço da marquise. Nesse ponto cabe uma pergunta. o corte da marquise e condição sine qua non para a conexão entre os edifícios? Não seria possivel uma alternativa que pudesse conviver com a marquise tal como ela foi construida? A proposta de Niemeyer a respelto do corre parece ter una dose exagerada da necessidade de "marcar sua que suficiente para isso

\section{Post mortem}

Oscar Niemeyer morre em 2012, poucos dias antes de completar 105 anos de idade. Deixa como legado um dos mais importantes conjuntos de obras construídas do século XX, no âmbito nacional e internacional. Além disso, são inúmeros estudos e croquis de obras que jamais saíram do papel e que, coerente com toda a discussão apresentada até aqui, também já não mais deveriam ser construídos.

No caso do Ibirapuera, a questão da marquise parecia ter sido encerrada

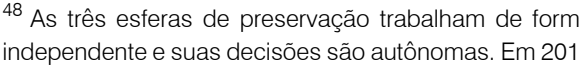

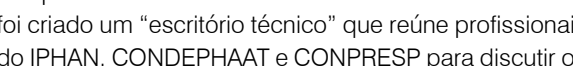
casos que dizem respeito aos bens tombados nas thes com o indeferimento dado pelo CONPRESP. Mesmo com a aprovação do IPHAN e CONDEPHAAT, a negativa inviabilizou a execução do projeto ${ }^{48}$.
Entretanto, foi aberto um processo no Ministério Público do Estado, na área de gão.

A entrada principal do parque, entre a Oca e o auditório, permanece como um estacionamento de veículos e, evidentemente, merece um projeto que a qualifique.

Em 2015, o promotor Dr. Luis Roberto Proença convocou uma reunião com pessoas que ele julgava poderem contribuir para a discussão. Estavam presentes Cecilia Scharlach ${ }^{49}$, o prof. Carlos Lemos ${ }^{50}$. Helio Pasta ${ }^{51}$, Ciro Pirondi ${ }^{52}$ e Silvio Oksman ${ }^{53}$.

Logo na abertura da reunião, ao colocar a questão sobre como tratar a entrada principal do parque, a resposta da maioria dos participantes foi de desenvolver o projeto de Niemeyer e executá-lo. Levantaram também o desgosto de Niemeyer com o veto à sua proposta. O questionamento da decisão do CONPRESP compreendia que Niemeyer teria autoridade inquestionável sobre sua própria obra. Nesse momento, coerente com toda a discussão colocada nesta tese, permaneci sem opinar. O procurador apresentou, então, cinco versões diferentes de estudos, inclusive uma que não cortava a marquise, todas propostas por Niemeyer (ver p. 174-177). Questionou aos presentes qual delas, então, deveria ser implantada. Colocado o impasse, iniciou-se uma discussão que, evidentemente, tratava de "supor o que o arquiteto faria". Discutiu-se quais das versões era aquela que Niemeyer gostaria de executar. Foram propostas alterações, sugeridos os sistemas construtivos e materiais de acabamento.

Após um tempo de discussão, posicionei-me contrário à execução de qualquer um dos estudos de Niemeyer, defendendo que qualquer arquiteto que compreendesse a obra do parque e tivesse reconhecida competência tecnica para desenvolver um proJeto novo para o acosso podenla apresentar uma boa soluça. Essa colocaçáo não se deu no sentido de desmerecer, a priori, o projeto de Niemeyer, mas de fazer uma leitura critica dele. Se a mienlyaçáa entre os edilcios parece ser oportuna, não há uma necessidade inexoravel de contar a marquise. Essa conexáo pode ser realizada de diversas ouras maneiras, em diálogo com a marquise na sua coniguraçáa alual. O conte é uma The de ser dispensavel. Mais do que isso, a reunico revelou a abordagem a partir do ato de ser um projelo de Niemeyer năo dos métlos da proposição. Ou seja, defend um projeto contemporâneo, em diálogo com o bem cultural.

Obviamente os demais participantes da reunião discordaram veementemente dessa posiçăo. Sugeriram consultar a prof a Mônica Junqueira de Camargo que havia feito parecer favorável ao projeto, conforme apresentado anteriormente. Levantei o fato de que, quando Camargo propôs a aprovação do projeto, Niemeyer ainda estava vivo $e$ que, com sua morte, provavelmente a discussão tomava outra direção.

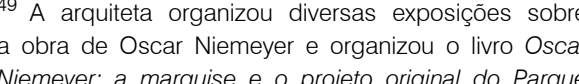
Nivemeyer: a marquise e o o proieto
libirapuera (2006), itiado anteriormente

${ }^{50}$ Arquiteto, professor da FAU-USP, colaborador de Oscar Niemeyer em diversos prose
hclusive no do Parcue libiapuera

Argutiteto, colaborador de Niemeyer em Săo Paulo. 52 Arquiteto, diretor da Escola da Cidade, membro da
Casa de Lúcio Costa.

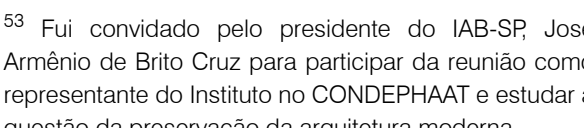
estâo da preservacāo da arquitetura moderna 
presente assinado pelos presentes e pelo promotor de justiça. Eu, Ricardo Santos Magalhães, Oficial de Promotoria, o digite

Aos vinte e oito dias do mês de agosto, na presença do Dr. LUIS ROBERTO PROENÇA, $4^{\circ}$ Promotor de Justiça do Meio Ambiente da Capital, compareceram o Sr. CIRO FELICE PIRONDI R.G. n. $6.748 .576-S S P / S P$, Arquiteto, Diretor da Escola da Cidade,

residente e domiciliado na Rua General Jardim n. 65, fone: 3258.81 .08 ,
Sr CARLOS ALBERTO CERQUEIRA LEMOS. R. . n. 1009.004 -SSPIS Sr. CARLOS ALBERTO CERQUEIRA LEMOS, R.G. n. 1.009.004-SSP/SP, Arquiteto, residente e domicliliado na Rua Martinico Prado n. 90, apt 135 SCHARLACH 0 Tone: 3225.00.45, a Sra. MARIA CECILIA CLOSS Rua Tupi n. 634, apto 84. CEP 01233-000, fones: 97595.99 .55 , 3666.98.50, Rua Tupi n. 634, apt 84, CEP 01233-000, fones: $97595.99 .55,3666.98 .50$
2799. 95.64 . o Sr. HÉLIO PASTA. R.G. n. 1.137.325. Arquiteto, residente domiciliado na Rua Bennet n. 291, CEP 05464-010, fones: 3022.88 .79 99491.92.09 e o Sr. SILVIO OKSMAN. R.G. n. 17.266.417-2. Arguiteto representante do IAB/SP. residente e domiciliado na Rua Maranhão o. 584 conjunto 22. CEP 01240-000, fones: 3259.74 .05 e 98193.01.90; os quais tiveram oportunidade de debater a respeito do teor da Açăo Civil Pública ajuizada pelo Ministério Público de Săo Paulo em face da Municipalidade de Săo Paulo (Proc. n. 0056447-29.2012.8.26.0053), que tem por objeto decisāo do CONPRESP que indeferiu o projeto de adaptacăo da majouise do Parque do lbirapuera à nova realidade trazida pela construçăo auditorio, sendo acordado pelos participantes ser relevante para a cidade São Paulo que a entrada do Parque no entorno do auditório e da Oca seja complementada, superando-se a atual situação de impasse, surgida a part da não aprovaçăo do projeto elaborado pelo escritório do Arquiteto Osca Niemeyer: que entendem que se mostra valilda a tentativa de pactuar-se un acordo com a Municipalidade de São Paulo, através dos órgāos envolvidos com a questẫo, e colocam-se à disposiçăo desta Promotoria de Justiça pa participar de futuras reuniöes com esta finalidade. Nada mais havendo, vai

Ml H. $20^{1}$

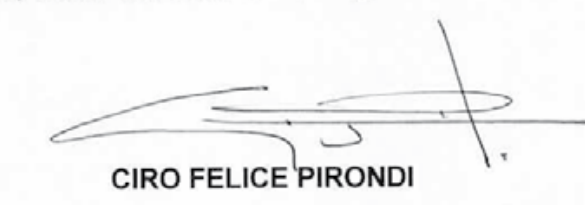

MM

CECILIA SCHARLACH

Jueluos anter

HÉLIO PASTA

HHo

Sutvio OKSMAN

D

LUIS ROBERTO PROENÇA
CARLOS ALBERTO CERQUEIRA LEMOS 
A conclusão da reunião, com que todos os presentes concordaram, foi da necessidade de um projeto para o acesso principal do parque. Ficou em aberta a discussão sobre qual proposta deveria ser realizada: se alguma daquelas apresentadas por Niemeyer no ińício dos anos 2000 ou algum novo projeto. Dr. Proença iria entrar em contato com o então Secretário Municipal da Cultura, Nabil Bonduki5 ${ }^{54}$, para discutir o tema.

Pouco tempo antes da reunião que aconteceu no Ministério Público, Nabil Bonduki já estava em tratativas com o arquiteto Paulo Mendes da Rocha e o escritório MMBB para desenvolvimento de um projeto para o acesso do parque.

O projeto apresentado remove o pátio de estacionamento entre a Oca e o auditório e desenha uma praça retangular que conecta os dois edifícios e a marquise. Não há nenhuma menção à ponta da marquise que se debruça sobre essa nova praça, permanecendo intacta.

Seguindo todas as recomendações referentes à conservação do patrimônio o projeto foi aprovado nos órgãos de preservação, já que a proposta é extremamente respeitosa em relação aos edifícios do parque.

Cabe discutir, entretanto, a contratação de Paulo Mendes da Rocha para desenvolver o projeto. Conforme colocado anteriormente, não se trata de questionar sua competência e capacidade de intervir em patrimônio cultural com maestria e o projeto apresentado ratifica essa questão.

A relevância de Mendes da Rocha no cenário nacional e internacional de arquitetura desde os anos 1950 Ihe confere um lugar de extremo respeito. Tanto no que diz ao respeito à sua obra, como a uma idolatria que inviabiliza olhares críticos. Mesmo aqueles que defendem o desenvolvimento do estudo de Niemeyer para a entrada do parque ficam em uma situação delicada para opinar. Isso seria se opor ao projeto de Mendes da Rocha. Ou seja, a escolha do arquiteto emudece toda e qualquer possibilidade de discussão das antigas propostas.

Mais do que isso, conforme já discutido no caso da Oca, a aquiescência ou a autorização de Niemeyer para que Mendes da Rocha interviesse na sua obra também é um argumento inquestionável. Assim, a obra que passa por uma intervenção nos anos 2010 continua sob a influência de seu autor.

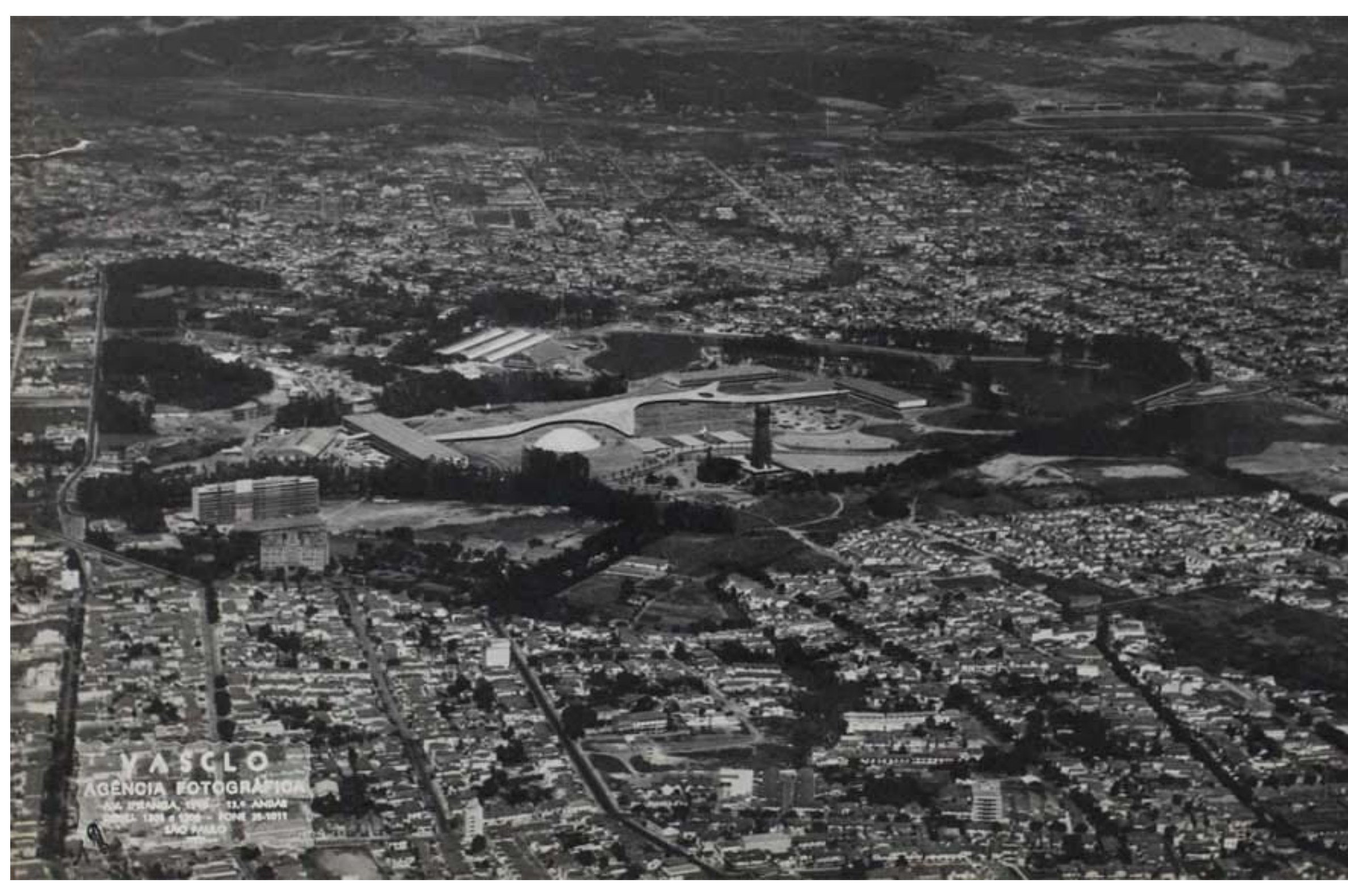


As questões apresentadas a respeito da arquitetura moderna permitem uma discussão ampliada sobre a preservação do patrimônio arquitetônico que não se restringe ao recorte estabelecido neste trabalho. Confirma-se a possibilidade de trabalhar com as diretrizes do restauro-crtico - que se mostram suficientemente abrangentes e
flexíveis - para a preservação do moderno, sem que haja empecilhos que invalidem essa corrente. A dificuldade aparece muito mais na questão da capacidade de leitura e na atribuição de valor, algo que acaba repercutindo nos projetos de preservação, conservação e restauro.

Nesse sentido, a colocação de Bruno Reichlin (2011, p. 13) "Costruire l'autocoscienza - epistemica ed ermeneutica - capace di pensare, insieme, sia l'oggetto che ci sta di fronte, sia gli strumenti storico-critici per andare incontro a quest'oggetto, è gia progetto." permela a tese e corrobora a necessidade de um aprofundado conhecimento da obra como parte integrante do projeto.

Do ponto de vista da valorização do patrimônio cultural, percebe-se a interferência de diversos fatores que não ficam limitados às questões da atribuição, mas que incluem questōes econômicas, sociais e simbólicas. O patrimônio participa, também, das políticas de valorização urbana e do turismo de massa, importantes ativos econômicos para as cidades de forma geral. Todos esses fatores influenciam o processo de reconhecimento Não que devam ser descartados, o que se mostra praticamente impossível, mas considerados com cautela para que não anulem os valores culturais. Outra questão importante ao se trabalhar com a arquitetura na virada do século XX e início do século em detrimento dos aspectos construtivos e dos programas arquitetônicos - que foram temas fundantes da arquitetura moderna. O campo do patrimônio fica neste momento, contaminado por essa postura da busca de uma imagem.

Além disso, no caso do moderno, o olhar fetichista que recai nessa produção arquitetônica e em seus autores interfere, por vezes positivamente, por vezes prejudicialmente no processo de preservação.

Levando-se em conta as revisões historiográficas do moderno e a constante tentativa de ampliar a compreensão do que foi a produção arquitetônica do século XX a abordagem dos grandes mestres modernos ainda é carregada de um viés mitificado, o que inviabiliza o distanciamento necessário para uma leitura crítica Ainda se observa, inclusive nas universidades, a dificuldade de criticas e de estudos que apontem suas contradicões e seus problemas já que grande parte dos trabalhos permanece com caráter laudatório. 
Na minha dissertação de mestrado essa questão aparecia em relação à sede da FAU-USP, na Cidade Universitária em São Paulo. A dificuldade de lidar com a obra de Artigas acabou levando o prédio a uma situação crítica, com sérios problemas de manutenção e conservação. Nesta tese, o edifício não é citado apesar de se encaixar plenamente nas discussões colocadas.

Neste trabalho, considerando especificamente o problema da autoria, confirmam-se as hipóteses anteriores, mas lançam-se outras, que envolvem a crise do projeto e a onipresença dos arquitetos e de seus herdeiros.

Acima de tudo, há ainda a dificuldade de dialogar com o fim de um período, com a necessidade do luto que, se mal elaborado, dificulta a abordagem dos processos históricos e a inserção do moderno no campo do patrimônio cultural, como uma importante produção do século XX que deve ser preservada. Assim, as propostas de preservação restauro tendem a evidenciar essa dificuldade com projetos que, na maioria das vezes, preferem tentar resgatar um suposto estado original das obras.

Se as propostas modernas do início do século XX propõem uma pauta para a arquitetura e para a cidade diretamente relacionada com um modo de vida, com a práxis cotidiana, e com novas tecnologias construtivas, parece que no final do século há uma leitura dessa produçâo apenas como imagem, os edificios ficam descolados dos principios que lines deram origem e de sua historia, como se fosse possivel fazer tal separação. A recuperaçâa se dá exclusivamente por uma abordagem estética. Açōes como essas retiram camadas importantes dessas obras e não são exclusivas do moderno. A proposta de recuperação de uma imagem consagrada, sem um olhar critico para as camadas que se sobrepoem ao objeto - que não estáo restritas apenas à recuperaçâa da materia - é prática comum para atingir um suposto estado de obra nova. A arquiteura vira efetivamente uma imagem e, nesse sentido, as obras de repristnação ganham espaço, mas será que atendem efetivamente ao desejo de preservar?

Trata-se de uma postura recorrente e, por isso, preocupante, que não se restringe ao campo da preservação do patrimônio cultural, mas que interfere também no campo da cultura e da história. Apagar marcas do tempo significa escolher a história que se quer preservar. Elimina a responsabilidade de refletir sobre a história com o máx mo de informações possiveis, permitindo, assim a compreensão das diversas camada que se sobrepõem. Não se trata da hipotética busca de uma verdade absoluta, mas da possibilidade de entender as interferências e a passagem do tempo.

A perspectiva de preservar as marcas do tempo pressupõe uma possibilidade que não necessariamente é uma garantia - de não apagar traços históricos, não apenas os que se restringem a materialidade dos edificios em questão, mas os que também refletem alos, casos, acontecimentos que tenham macado a sociedade e que podem estar representados nesses edifícios. Assim, evita-se a escolha, sempre arbitrária, de um momento idealizado que será estabelecido como o "momento a preservar". O apagamento de camadas sempre será um ato parcial, que define as épocas escolhidas e omite outras.

O que se observa é que as diretrizes para projetos de restauro - mínima intervenção, distinguibilidade, re-trabalhabilidade e utilização de técnicas compatíveis - têm sido usadas como cartilha, sem senso critico. Ou seja, aplica-se de forma pragmática os principios, com respostas técnicas que atendem apenas à preservaçáa da imagem, mas naao o patrimônio em toda a sua complexidade. Mesmo a manutençâo de marcas, sem o devido criterio, pode não ser suliciente para transmitir a informaçäo encontrada. Não é uma questão de fácil resposta e, alem disso, demanda propostas que organizem o conhecinento do problema colocado as soluçoes techicas possivelis e cr A dificuldade maior é encontrar a dosagem certa para esses elementos.

A ideia de falso, conforme discutido neste trabalho, vem sendo criticada por ser, supostamente, um conceito conservador que busca uma verdade hipotética e desnecessária. No entanto, o que se tentou discutir foi a possibilidade de ampliar as leituras do patrimônio e da história. Se uma intervenção em um bem cultural levanta dúvidas sobre a história de um edifício, estará colaborando para uma abordagem incompleta e tendenciosa - até mesmo falsa - ainda que muitas vezes os autores das propostas nem mesmo se deem conta do equívoco cometido'. Outra questão importante é que, para apresentar as camadas históricas de uma obra, o "produto final" pode não atingir o aspecto de "obra nova" o que pode desagradar aqueles que anseiam por uma obra antiga com cara de recém-construída.

Assim, um edifício não pode ter sua abordagem pautada apenas pela sua imagem, devendo abarcar questões documentais, memoriais simbólicas etc. Foi isso que se tentou abordar. O foco apenas nas discussões técnicas elimina as camadas dos acontecimentos mútiplos que podem, em alguns casos, ser essenciais. Muitos deles deixam marcas sobre a materia que tambem devem ser consideradas, pois são elas que permitem compreender a passagem do tempo e dos fatos. Apagá-las é uma ação tecnicamente possivel, mas isso implica, no entanto, o apagamento das marcas e cicatrizes que revelam a historia real, não apenas do edificio mas de todos os fatos que envolvem sua existência. Construçôes novas que pretendam substituir obras que tenham desaparecido também omitem parte significativa da historila. A materila é, nesses casos, o principal testemunho da passagem do tempo, das modificações feitas, dos traumas sofridos.

A participação crescente da sociedade nas discussões sobre a preservação do patrimônio cultural coloca em pauta a necessidade de tentar alcançar a maior abrangência possivel, sem priorizar determinados grupos ou as histórias oficiais. Cada vez mais, grupos que sete pouco tempo não tinham como se expressar equestic $C$

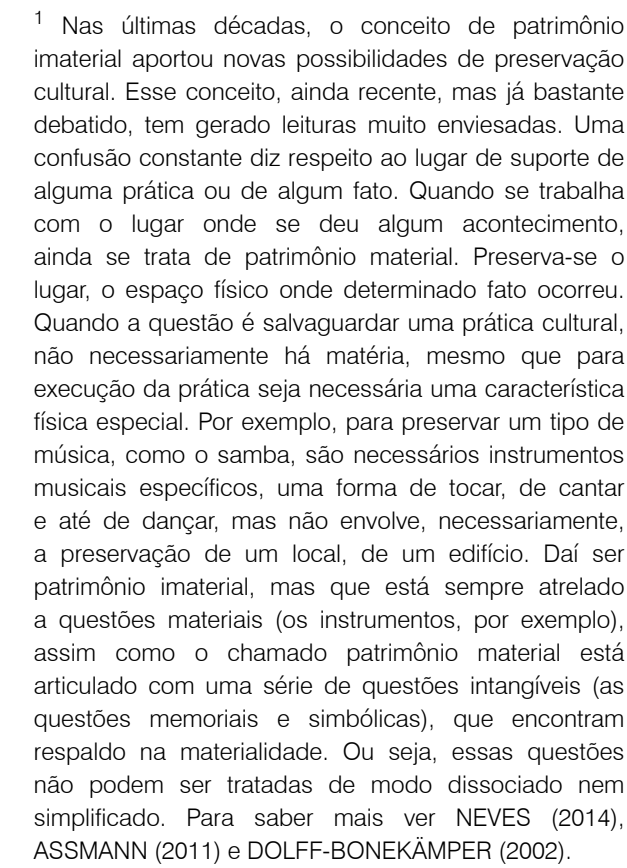

simplificado. Para saber mais ver NEVES (2014)
ASSMANN (2011) E DOLFF-BONEKAMPER (2002) 


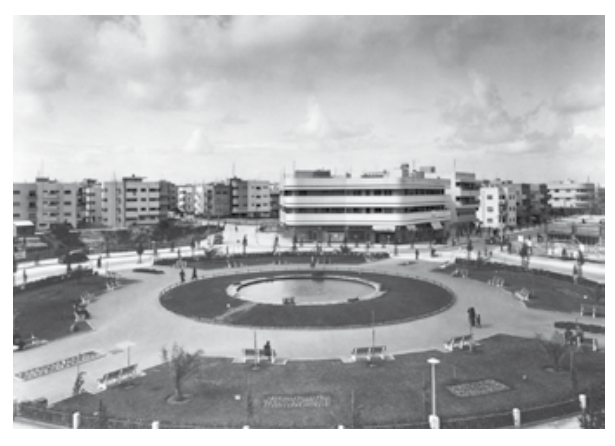

109. Tel Aviv Branca- Israel do campo do patrimônio inclui essa crescente discussão. Edifícios e lugares que até recentemente não eram considerados no campo da preservação cultural - que tratava prioritariamente de obras excepcionais por suas qualidades plásticas ou pela relevância dos fatos a elas associados (segundo uma dada visão da história), os chamados monumentos artísticos e históricos - vêm ganhando seu lugar. Campos de concentração, lugares de tortura das ditaduras militares da América Latina, cemitérios - oficiais e clandestinos - lugares de violência contra grupos étnicos e minorias (pelourinhos, missões etc.), tragédias de diferentes origens passam a fazer parte de lugares e edificaçōes que devem ser preservados.

Nesse sentido, um caso que não foi abordado nos capítulos anteriores, mas que está intrinsecamente atrelado à discussão apresentada, pode ilustrar claramente essa ideia, já que também abre outras perspectivas para novos estudos. Trata-se de um dos edificios mais emblemálicos dos primórdlos da arquiturura modema na Alemanha: sede da escola Bauhaus, projetado por Walter Gropius (1883-1969), em Dessau.

A proposta da Bauhaus questionava o ensino e a prática da arquitetura. Por isso, a escola e seu edifício-sede são reconhecidos como as principais obras desse período. A proposta didática da escola tem origem na ideia de articular arte, artesanato e a produção em série, rompendo com as práticas acadêmicas de arquitetura e arte até aquele momento Os professores são, além de arquitetos, artistas de diversas tendências das vanguardas europeias.

O edifício projetado por Gropius representava os anseios acadêmicos da escola. Já no primeiro programa do curso o arquiteto estabelece:

[...] todos nós arquitetos, escultores, pintores, devemos voltar-nos para nosso oficio. A arte náo e uma profissão, náo existe nenhuma diferença essencial entre $\mathrm{o}$ artista e $\mathrm{o}$ artesão $[\ldots]$ for mamos uma única comunidade de art́fices sem a distinção de classe que levanta uma arrogante barreira entre $\mathrm{o}$ artesão e $\mathrm{o}$ artista. Juntos concebemos e criamos o novo edifício do futuro, que reunirá arquitetura, escultura e pintura numa única unidade, e que um dia será levantado contra o céu pelas mãos de milhões de trabalhadores como o símbolo de cristal de uma nova fé. (BAYER, W. GROPIUS, I. GROPIUS, 1952, p. 16 apud BENEVOLO, 2006 p. 404)

A ideia fundamental é utilizar o artesanato não mais como objetivo ou como ideal romântico, mas como meio didático para a preparaçáa dos projetistas modernos, capazes de imprimir nos produtos industriais uma ńtida orientação formal Diante da polêmica entre artesanato e indústria, que se desenrola há um decênio na Werkbund, Gropius não se decide por um ou outro desses poopostas. (BENEVOLO, 2006, p. 406) $)^{2}$

Na primeira metade do século XX, ocorre a ascensão do regime nazista na Alemanha, que classifica como "degenerada" toda obra que foge dos padrões clássicos de beleza. Isso inclui, evidentemente, a arte moderna, que passa a ser recolhida e destruída pelo governo ${ }^{3}$.

Com o avanço do nazismo em Dessau, em 1932, a Bauhaus se transfere para Berlim, onde continuou a funcionar até seu fechamento definitivo em $1933^{4}$, sob a direção de Mies van der Rohe ${ }^{5}$. Devido à perseguição, a partir desse momento não houve mais espaço para as propostas da Bauhaus no país. Além disso, vários arquitetos e artistas que trabalhavam na Alemanha eram judeus e tiveram que fugir para outros países nesse período.

A saída forçada teve como consequência a difusão internacional dessa arquimundo. O fechamento da escola e a diáspora dos arquitetos e artistas repercutiram diretamente em toda a produçáo de arquitetura no século XX, a que seus princípios foram amplamente divulgados e construídos em lugares aonde, talvez, jamais teriam chegado. Não por outro motivo, a cidade de Tel Aviv, em Israel, tem um bairro construído por arquitetos vinculados à Bauhaus: Tel Aviv Branca. Os Estados Unidos também foram destino de parte desses arquitetos que aí desenvolveram suas atividades profissionais. Mesmo com o fim da escola em 1933, os reflexos da sua atuação são amplamente difundidos, como consequência da situação política da Alemanha no período entre guerras.

O edifício em Dessau foi duramente atingido durante a Segunda Guerra Mundial, tendo se transformado em quartel e ficado bastante deteriorado. Parte do conjunto desabou devido a bombardeios.

Contar a história da escola, de sua proposta acadêmica, de seus alunos e proessores e do prédio significa entrar em aspectos que transcendem a proposta didática, a produção e a imagem do edifício. Trata-se de abordar toda a conjuntura política daquele momento, que teve influência nesse processo de forma direta.

Em 1964, o edifício da Bauhaus foi incluído na Lista de Monumentos do distrito de Dessau'. Em 1976, uma intervenção foi realizada com a construção dos volumes que haviam sido destruídos, além de algumas outras obras em alguns elementos, como o grande caixilho da fachada, por exemplo, com o objetivo de uma recuperação do aspecto original.
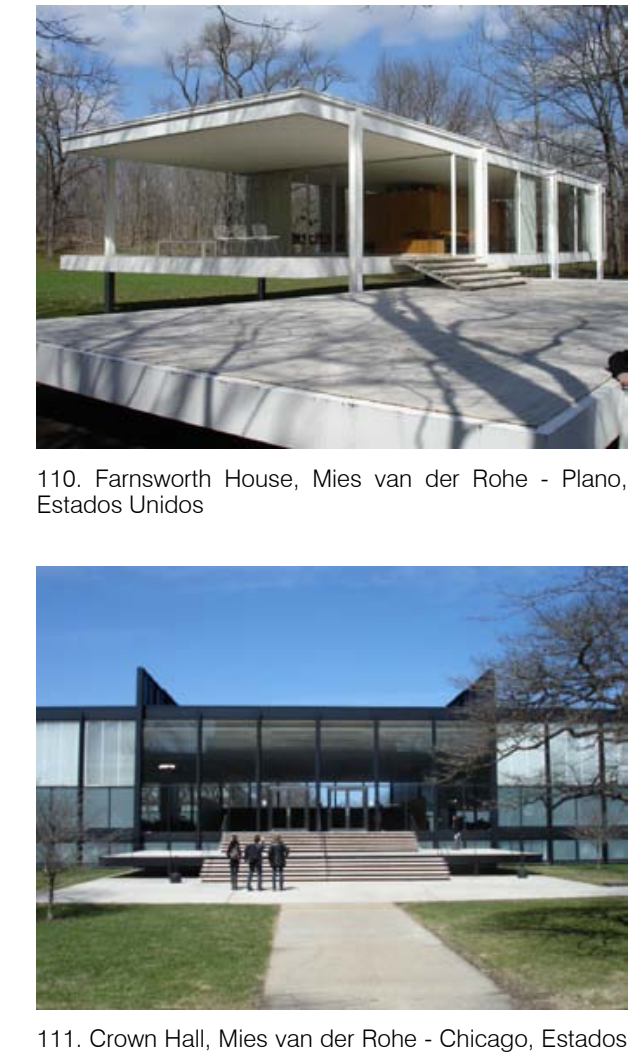

111.0 cind
Unidos

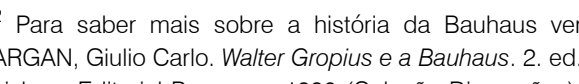

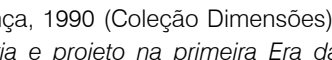

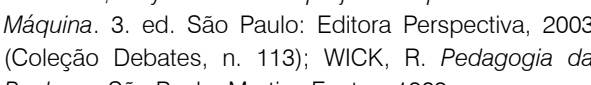

Para saber mais sobre a questáo das artes durante
governo naista ver Barron Stephanie ed. (1991)

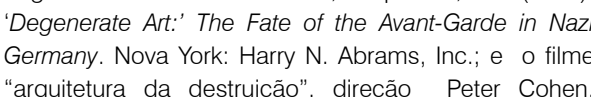
Germany. Now
"arautitura
Suécia 1992

4 Ano en
alemão.

que Adolph Hitter é nomeado chanceler

Em Mies van der Rohe at work (CARTRR, 1974), hid

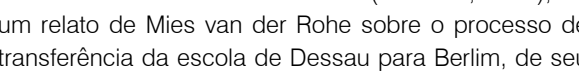
echamento definitivo em 1933, e da ida do arcuite para os Estadas Unidos poucos anos depois 6 Conforme discutido no capitulo 2, os edifícios
canononicos da arcultetura moderna foram os primeiros a 


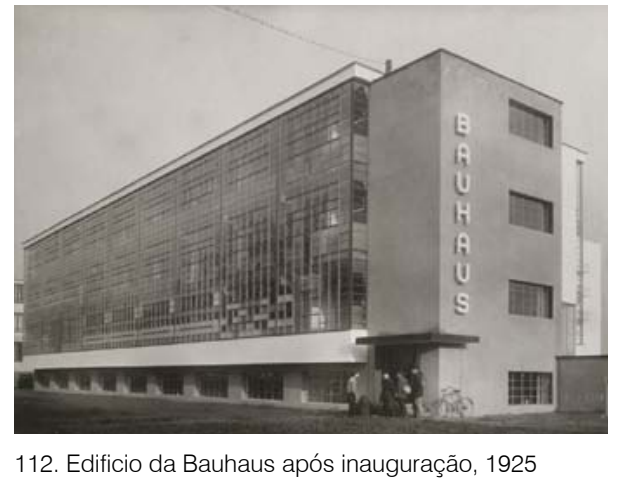

Em 1996, os edifícios da Bauhaus em Weimar e em Dessau foram inscritos na Lista do Patrimônio Mundial da Unesco. Nesse mesmo ano, iniciou-se um processo de repristinação, chamado de restauro, na busca de um suposto estado original. O resultado, para o edifício de Dessau, foi um prédio com cara de novo, que recupera a imagem que fez parte da equipe de arquitetos do projeto:

The extensive work on the building ranged from the regeneration of the supporting structure and the shell of the building to the reconstruction of the original layout of rooms, the functiona

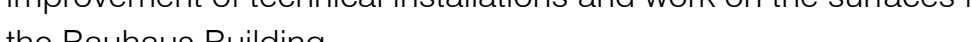
the Bauhaus Building

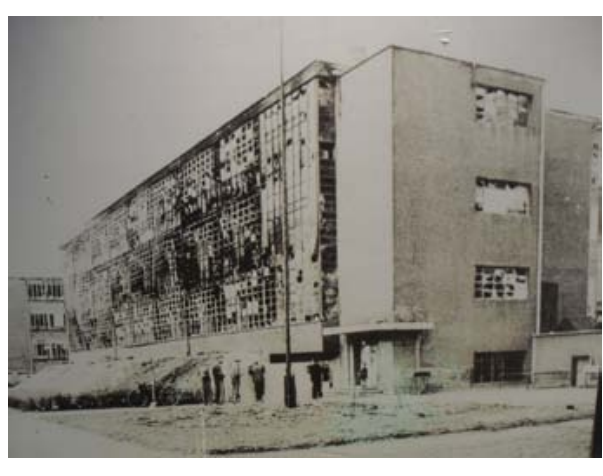

Atualmente, o edifício é sede da Bauhaus Dessau Foundation e recebe um grande número de visitantes a cada ano.

Segundo Markgraf, foi feito um grande levantamento sobre o edifício com a intenção de conhecê-lo da melhor maneira possível e propor os trabalhos de recuperação que também tiveram que tratar da adaptação para novos usos, com novas instalaçōes de tecnologia. Os levantamentos métricos, as prospecções, as análises de laboratório e a organização da documentação existente permitiram compreender diversos aspectos da construção. No entanto, chama a atenção que no único momento em que trata do estado de conservação do edifício nos anos 1940, os estudos descrevem as destruiçoes da guerra como "series of destuctive events", sem masores detalhes di

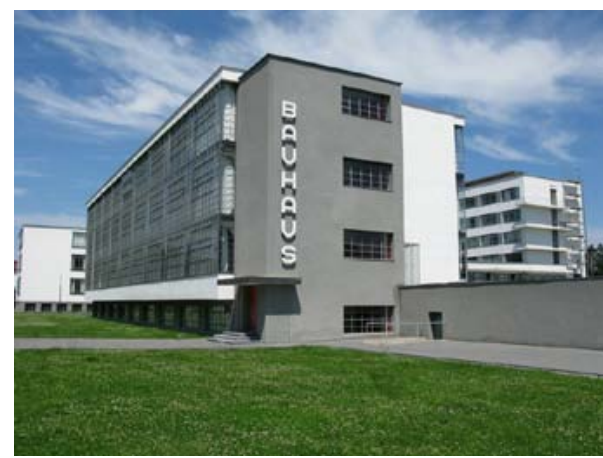

Ainda segundo a autora, os trabalhos foram divididos em função de três abordagens: reconstrução e recuperação de áreas, restauro de áreas que haviam sido ateradas na reforma de 1976, e manutenção das áreas que ainda apresentavam boas condições e grande parte do edifício original.

Apesar de usar os princípios da Carta de Veneza, a autora evidencia a deliberada intenção de recuperar uma imagem original. Os trabalhos foram criteriosos do ponto de vista técnico, dos materiais e tecnologias utilizados. Mas do ponto de vista da leitura crítica do edifício, a abordagem se dá, sempre, no sentido da recuperação da sua imagem e espacialidade supostamente originais.

Justificam-se as ações de recuperação a partir das diretrizes contemporâneas de preservação, mas ignora-se que não há nelas nenhuma intenção de recuperação de um estado original. Pelo contrário, a Carta de Veneza preconiza a necessidade de "[...] respeito ao material original e aos documentos autênticos" (CURY, 2000, p. 93) o que significa o profundo reconhecimento do bem, mas não intenciona a volta a um estado original. Mesmo que as ações técnicas estejam pautadas por essas diretrizes e, portanto, possam ser assim defendidas, o objetivo final da repristinação omite questôes fundamentais para a compreensão da escola, do edifício e da arquitetura moderna pelo mundo.

Não há marcas do tempo, das transformações e do abandono. Não é possível entender no edifício o que foi a Segunda Guerra para a escola, para esses arquitetos, violentos do século XX.

No livro Bauhaus Dessau? que apresenta o edifício depois desse processo, há uma quantidade significativa de imagens que mostram os detalhes de mobiliário, de ferragens, vários deles refeitos à imagem e semelhança dos originais. No texto de apresentação, escrito por Omar Akbar, presidente da Bauhaus Dessau Foundation fica evidente a proposta de um edifício completamente recuperado "conforme o original". Não há nenhuma citação dos episódios que levaram o prédio a um péssimo estado, e das partes que foram demolidas. Não há nenhuma citação sobre a guerra Apenas a comemoração do edifício da escola que "recuperou sua condição original".

Importante reafirmar que, em 1996, o processo de reunificação da Alemanha ${ }^{8}$ já estava bastante avançado. Berlim volta a ser a capital da Alemanha em 1991 e, desde então, diversas ações objetivam retomar uma situação pré-guerra. Uma das que mais chama atençáo e a consiruçáo do castelo de Berlim, que busca a imagem do castelo que deu origem à cidade, construído a partir do século XIV e que foi demolido em 1950 pelo governo da República Democrática Alemãa. A movimentação para essa construção tem sido pautada por um resgate da cultura prussiana - anterior ao século XX e, portanto, às duas guerras mundiais. As partes remanescentes do Muro de Berlim, que separou a cidade durante 28 anos (1961-1989) e foi uma das marcas da separação do mundo no pós-guerra, também já não têm a força do que representavam à época da reunificação do país.

É nesse contexto que se realiza o projeto de intervenção no edifício da Bauhaus. O projeto de restauro que recupera a imagem canônica, idealizada do edifício, esconde mais do que as marcas da guerra ou da ascensão do nazismo omite parte significativa da história do século XX.

Desse modo, um questionamento que perpassa esta tese e que a encerra é: a quem pode interessar uma história "editada", privada de suas contradiçoes, que apaga traços que representam a passagem das obras através do tempo, e destigura numeexistência?
BAUMANN, Kirsten. Bauhaus Dessau. Architecture
Design Concept. Berlim: Jovis Verlag GmbH, 2007.

O processo de unificacăa entre a RDA (República
Democrática Alemă, ou Alemanna Orienta) e a RFA Repúbilica Federal da Alemanha, ou Alemanh

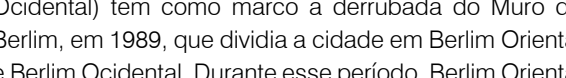
Permaneceu comono capital da RaAA, e a capatial da RFA foi transferida a para Bonn. Na reunificacaăo, o Reichstag,
citado no capituo 2 desta tese, volta a ser a sede do
parlamento alemão.

9 Para saber sobre o historico do castelo e sobre
construçäo em andamento ver BACELAR, Gabriel

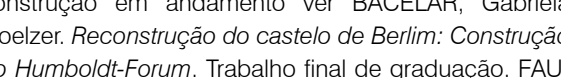

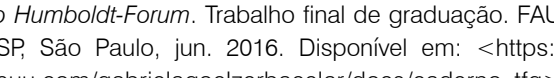
issuu.com/gabrielagoo 



\section{CRÉDITOS DAS IMAGENS}

\section{Introdução}

Img. 01 - Edifício Sede do Instituto de Arquitetos do Brasil - Departamento de São Paulo. Autor: Rafael Schimidt

Img. 02 - Pavilhão de Barcelona de Mies van der Rohe em 1929 e sua reinterpretação de 1986

Acervo Biblioteca da FAU-USP e Acervo Silvio Oksman

Img. 03 - Pinacoteca do Estado de São Paulo

Autor: Nelson kon

Img 04 - Museu Reina Sofia - Madri

Acervo Silvio Oksman

Img 05 - Museu do Louvre - Paris

Acervo Silvio Oksman

\section{Valorização}

Img 06 - Intervenção de Jean Nouvel no Museu Reina Sofia em Madri

http://img.archiexpo.com/images_ae/photo-g/1616-7218995.jpg

Img 07 - intervenção de Zaha Hadid no porto de Antuérpia

Acervo: Prof. Beatriz Mugayar Kühl

Img 08 - Pavilhão em Barcelona de Mies Van Der Rohe, 1929 Autor não identificado. In CARTER, 1999

Img 09 - Pavilhão em Barcelona construído à imagem do pavilhão de Mies Van der Rohe (1929), 1986

Acervo Silvio Oksman

Img 10 - Pavilhão Esprit Nouveau, em Paris, de Le Corbusier, 1925 LE CORBUSIER, 1995. vol 1 p. 100 
Img 11 - Pavilhão em Bolonha construido à imagem do Pavilhão Esprit Nouveau, de Le Corbusier (Paris, 1925), 1977

Acervo Silvio Oksman

Img 12 - Plano de conservação para Bologna, 1969

http://www.fredmussat.fr/e-proceedings2_dec09/mirror_of modernity bravo htm

Pier Luigi Cervellati, Roberto Scannavini, Carlo De Angelis, La nuova cultura delle città.

La salvaguardia dei centri storici, la riappropriazione sociale degli organismi urbani e

che, Mondadori, Milano 1977

Img 13 - Restauração do bloco urbano de San Leonardo, Bologna, 1975-85

Pier Luigi Cervellati, Roberto Scannavini, Carlo De Angelis, La nuova cultura delle città.

La salvaguardia dei centri storici, la riappropriazione sociale degli organismi urbani

l'analisi dello sviluppo territoriale nell'esperienza di Bologna, Edizioni scientifiche e tecni-

che, Mondadori, Milano 1977

http://wnw.fredmussat.fr/e-proceedings2_dec09/mirror_of_modernity_bravo.htm

Img 14 - Pelourinho, Salvador, antes da intervenção

https://dezoitoevintetres.files.wordpress.com/2013/05/pelourinho-salvador-bahia.jpg

Img 15 - Pelourinho, Salvador, após a intervenção

http://www.pousadasalvador.net/wp-content/uploads/2015/07/pelourinho.jpg

Img 16 - Centro de Recife após intervenção

http://transferrecifeporto.com.br/wp-content/uploads/2014/06/recife-antigo.jpg

Img 17 - Paris, 1943. Área da futura implantação do Centro Georges Pompidou

Fonte: Google Earth

Img18 - Paris, 2016. Área após a implantação do Centro Georges Pompidou

Fonte: Google Earth

Img 19 - Centre National d'art et culture Georges Pompidou

Autor: Michel Chéron, 2010

Img 20 - Torre Velasca - Milão - Vista a partir da Cobertura da Catedral

http://images.adsttc.com/media/images/5038/13cd/28ba/0d59/9b00/0d01/large jpg/ stringio jpg?1414198752
Autoria

Img. 21 - Igreja de São Francisco, Pampulha, Belo Horizonte

Acervo Silvio Oksman

Img. 22 - Museu de Arte de São Paulo, 1969.

Autor: Hans Gunter Flieg - Acervo Instituto Moreira Salles

Fonte do dado: http://blogdoims com br/dois-momentos-marcantes-de-lina-bo-bardi/

Img 23 - Faculdade de Arquitetura e Urbanismo da Universidade de São Paulo (FAU-USP)

Acervo Biblioteca FAU-USP

Img 24 - Teatro armando Gonzaga. Rio de Janeiro

http://mapio.net/pic/p-69515474/

Img 25 - Obra do Berço. Rio de Janeiro

UNDERWOOD, 1994, p.31

Img 26/27 - Villa Savoye após a sua inauguração, 1928

LE CORBUSIER, 1995. vol 2 p. 31

Img 28 - Villa Savoye antes dos processos de repristinação, 1958

http://arquitetablog.blogspot.com.br/2011/04/villa-savoye-antes-da-restauracao.html

Img 29 - Vila Savoye após o processo de repristinação, 1993

https://static.dezeen.com/uploads/2016/07/villa-savoye-le-corbusier-poissy-franceunesco-world-heritage dezen_1568_12.jpg

Img 30/31 - Carta de Oscar Niemeyer ao IPHAN pedindo o tombamento de suas obras Fonte: IPHAN, 2007

Img 32 - Conjunto Robin Hood Garden, Londres

Img 32 - Conjunto Robin Hood Garden, Londres -hood-gardens/

Img 33 - Demarcação da área do BlackWall Reach no East End londrino

http//mww.clarkebond com/blackwall_reach/ 
Img 34 - Conjunto Robin Hood Garden, Londres

http://www.architravel.com/architravel/building/robin-hood-gardens/

Img 35 - Imagem do BlackWall Reach na área do Conjunto Robin Hood Garden

http://blackwallreach.co.uk/site-plan/

Img 36 - Conjunto Robin Hood Garden com edifícios de novos empreendimentos ao fundo

http://karakusevic-carson.com/system/dragonfly/production/2014/07/08/nkcyhh9b1

blackwall_reach_existing_3_.jpg

Img 37 - E-mail de Richard Rogers e Simon Smithson

Acervo Silvio Oksman

Img 38 - Conjunto Fabrica Peixe-Duchen

http://www.saopauloantiga.com.br/biscoitos-duchen-historia-e-demolicao/

Img 39 - Fabrica Peixe-Duchen

http://almanaquedomalu.blogspot.com.br/2015/05/foto-do-mes-fabrica-da-duchen-na-viahtml

Img 40 - Fabrica Peixe-Duchen

Autor: Hans Gunter Flieg - Acervo Instituto Moreira Salles

Autor. Hans Gin ir Fligg - Acervo Instituto Moreira Salles

Img 41 - Carta de Oscar Niemeyer para o CONDEPHAAT

CONDEPHAAT, 1986, p. 65

Img 42 - Fotos arquiteto B. Castello branco

CONDEPHAAT, 1986

Img 43/44/45 - Imagens do laudo de 1990

CONDEPHAAT, 1986 , p. 158

Img 46 - Sociedade Harmonia de Tenis

ÁVILA, Fábio Augusto de Brito (Org.). Fábio Penteado. Ensaios de arquitetura. São Paulo, Empresa das Artes, 1998. p.172

Img 47 - Sociedade Harmonia de Tenis

Acervo Silvio Oksman
Img 48 - Intenvençáo posterior, elevador e ar-condicionado

Acervo Silvio Oksman

Img 49 - Edifício Pirelli após o acidente em 2002

hittp://mww fotogratieitalia it/foto $c f m$ ?idfoto $=47358$ \&idcategoria $=7$ \&idregione $=9$

Img 50 - Edifício Pirelli após o restauro de 2004

http://permilano.it/zona_2/davedere_2il-pirellone-il-grattacielo-pirell//

Img 51 - Vista aérea do Weissenhofsiedlung Stuttgart, 2004

https://upload. wikimedia.org/wikipedia/commons/5/50/Weissenhof-Luftbild-2004.01.jpg

Img 52 - Rathenaustraße de Le Corbusier e Pierre Jeanneret, 1930

https://thecharnelhouse. org/2015/03/14/stuttgart-weisenhof-1927-modern-architecture-

comes-into-its-own/robert-bothner-stuttgart-arbeiter-wohnhaus-von-le-corbusier-in-der-weisenhofsiedlung-rathenaustrase-1-3-1930/

mg 53 - Weissenhofsiedlungmuseum após intervenção, 2006

https://upload wikimedia org/wikipedia/commons/thumb/8/8d/Weissenhof Corbusier 03.jpg/1024px-Weissenhof_Corbusier_03.jpg?1483641017810

Img 54 - Cartão postal da "colônia de Weissenhofsiedlung", 1927

http://catalog quittenbaum de/index php? function = 0 bjectDetail\&Datensatz

$\mathrm{D}=654658$ b biekt $\mathrm{D}=654658 \mathrm{l}$ anguage $=$ eng\&iFound Objects $=1458 \mathrm{positon} \mathrm{n}$ List $=5$

18listRedirect=ind

I \& listRedirect=index.php\%3F_function\%3Dlist_objects\%26amp; Language\%3Deng\%2

6amp; _start\%3D40\%26amp;Language\%3Deng\%26amp;Standort_ID_Auktion\%3DM_1

ObB\%26amp;Zuschlag\%3D\%26amp,\%26amp,khnOListView\%3DicView\%26amp;\%23
Object65465\&

Img 55 - Casa Modernista da Rua Santa Cruz, 1927
https://mdc.arq.br/2015/02/25/antonio-garcia-moya-um-arquiteto-da-semana-de-22-parte-2/07-warchavchik/

Img 56 - Casa Modernista da Rua Santa Cruz, 1927

http://www.archdaily.com.br/br/01-17010/classicos-da-arquitetura-casa-modernista-

-da-rua-santa-cruz-gregori-warchavchik/5627b767e58ece127a000256-classicos-da- 
Img 57 - Casa Modernista da Rua Santa Cruz após as diversas intervenções

http://www.archdaily.com.br/br/01-17010/classicos-da-arquitetura-casa-modernista-

-da-rua-santa-cruz-gregori-warchavchik/5627b5e3e58ecee6f0000266-classicos-da-

-arquitetura-casa-modernista-da-rua-santa-cruz-gregori-warchavchik-foto

Img 58 - Teatro Cultura Artística antes do incêndio de 2008

http://blog.distinctioninmosaics.com/wp-content/uploads/2010/05/tca.jpg

Img 59 - Teatro Cultura Artística durante o incêndio de 2008

http://aengenhariaevoce blogspot com.br/2010/05/praca-roosevelt-e-teatro-cultura html

Img 60 - Remanescentes do Teatro Cultura Artística após o incêndio

Autor: Thais Marcussi

Img 61 - Noticia da Folha de S. Paulo, 2008

http://www1.folha.uol.com.br/fsp/cotidian/ff1908200803 htm

Img 62 - Estádio Le Corbusier no conjunto de Firminy

http://arquitetura-rte.blogspot.com.br/2010/05/seguir-serao-mostradas-fotos-de.html

Img 63 - Embasamento da Igreja de São Pedro, projeto de Le Corbusier, em Firminy

http://lunieutaire.over-blog.com/page-779201.htm

Img 64 - Maquete do projeto de Le Corbusier para a Igreja de São Pedro, em Firminy

LE CORBUSIER, 1995

Img 65 - Igreja de Firminy após inauguração nos anos 2000

LE CORBUSIER, 1995

Img 66 - Croqui de Le Corbusier para a igreja de Firminy

LE CORBUSIER, 1995

Img 67 - Desenho de Ramos de Azevedo para o Liceu de Artes e Ofícios de São Paulo http://fi. iuol.com.br/fotografia/2012/10/21/201234-970×600-1.jpeg

Img 68 - Pinacoteca do Estado de São Paulo após intervenção de Paulo Mendes da Rocha

Autor: Nelson Kon
. ichstag antes da II Guerra Mundial, Berlim

http://blog.berlinallin.com/german-reichstag-a-short-history/

Img 70 - Reichstag após bombardeios da II Guerra Mundial

http//24 media.tumblr.com/tumblr mbwu6iog361qasw0401_1280.jpg

mg 71 - Reichstag após intervenção de Norman Foster

http://roma-berlinenbici blogspot com br/2013/08/brandenburgo html

Imh 72 - Igreja de São Pedro em obras, em Firminy. Projeto de José Oubrerie

http://static.panoramio.com/photos/large/15063980.jpg

Img 73 - Reinterpretação do Pavilhão de Barcelona, 1986 Acervo Silvio Oksman

Img 74 - Reinterpretação do Pavilhão de Barcelona, 1986 Acervo Silvio Oksman

Img 75 - Pavilhão de Barcelona, 192 


\section{Ibirapuera}

Img 76 - Projeto de Stockler das Neves

Acervo Biblioteca da FAU-USP

Img 77 - Proposta da equipe chefiada por Rino Levi

Arquivo DAHM-DPH. In: MIGLIONICO, Rosa Italica. Parque do Ibirapuera: Um ícone da

paisagem paulistana. Doutorado apresentado a FAUUSP. São Paulo, 2007 . p. 143.

Img 78 - Projeto de Paisagismo desenvolvido por Burle Marx

Acervo MoMA. Autor: Vitor Hugo Mon

Img 79 - Croqui de estudo de Oscar Niemeyer

Arquivo DAHM-DPH. In: OLIVEIRA, Fabiano Lemes de. Projetos para o Parque do lbirapuera: de Manequinho Lopes a Niemeyer (1926-1954). Dissertação de Mestrado -

Img 80 - Cópia artigo, MÓDULO, n. 66. (14 páginas)

Acervo Biblioteca FAU-USP

Img 81 - Planos diretor para o Parque lbirapuera (8 páginas)

DOM. São Paulo, 24 jul. 1996, p.4-11.

Img 82 - Projeto de Lina Bo Bardi para o MAM, 1982

FERRAZ, 1996, p. 255

Img 83 - Planta atual do MAM

Acervo Metrópole Arquitetos

Img 84 - Aranha, de Louise Bougeois

Acervo Silvio Oksman

Img 85 - MAM - área do restaurante com vidros escuros que não permitem a visão do lado de dentro do edifício. O Museu ampliou a sua área também com a utilização de limitadores de circulação, estreitando ainda mais a circulação pela marquise.

Acervo Silvio Oksman

Img 86 - A ocupação da marquise pelo MAM interfere na relação da Marquise com ao acesso da Bienal

Acervo Silvio Oksman
Img 87 - Fechamento do fundo do Museu/ Estacionamento

Acervo Silvio Oksman

Img 88 - MAM

https:/2 bp blogs

-FbNgPpV-GubOHYTUkp3KW'CLCB/s1600/mam fachada-foto-karina-bacci-1.jpg

Img 89 - Intervenção no acesso da Oca

Autor: Nelson Kon

Img 90 - Intervenção no interior da Oca

Autor: Nelson Kon

Img 91 - Vista aérea da construção do Parque lbirapuera nos anos 1950

http://parqueibirapuera. org/wp/wp-content/uploads/2016/03/FOTOLABOR-Werner-Haberkorn.-S\%C3\%A3o-Paulo-Brasil.-Vista-a\%C3\%A9rea-da-constru\%C3\%A7\%C3\%A3o-do-Parque--lbirapuera-no-in\%C3\%ADcio-dos-anos-195-

Img 92 - Carta de Edemar Cid Ferreira a Niemeyer

Acervo IPHAN

Img 93 - Resposta de Niemeyer a Edemar Cid Ferreira

Acervo IPHAN

Img 94 - Vista aérea do Parque Ibirapuera antes da construção do auditório

MANCHETE, IV Centenário de São Paulo. Rio de Janeiro, n especial, 1954. Sem numeração - Autor desconhecido

Img 95 - Construção do novo auditório

https://s-media-cache-ako pinimg.com/236x/d5/e1/2e/d5e12e027b922389d7ac$65 \mathrm{~b} 8437468 \mathrm{ec} . j \mathrm{jpg}$

Img 96 - Projeto de Niemeyer para o auditório do Ibirapuera, 1953 CONPRESP Processo 2004-0.154.355-9

Img 97 - Projeto de Niemeyer para o auditório do Ibirapuera, 2003 CONPRESP, Processo 2003-0.035.768-7 
Img 98 - Projeto de Niemeyer para o auditório do Ibirapuera, maio de 2004

CONPRESP, Processo 2004-0.154.355-9

Img 99 - Projeto de Niemeyer para o auditório do Ibirapuera, maio de 2004

CONPRESP, Processo 2004-0.154.355-9

Img 100 - Projeto de Niemeyer para o auditório do lbirapuera, outubro de 2004

Processo 2004-0.154.355-9

Img 101 - Palco do auditório aberto para o parque

http://www.itaucultural.org.br/explore/blogs/alem-da-agenda/auditorio-ibirapuera-me-

Ihor-casa-de-s

Img 102 - Vista aérea do auditório

http://www.taucultural.org. br/explore/blogs/alem-da-agenda/horario-especial-da-bilhe-

teria-do-auditorio-ibirapuera/

Img 103 - Maquete de estudo de Niemeyer para intervenção na marquise

http://www.vitruvius.com.br/media/images/magazines/grid_9/3068_188-07.jpg

Img 104 - Trecho de marquise que Niemeyer pretendia demoli

Acervo Silvio Oksman

Img 105 - Estacionamento no aceso do parque entre a Oca e o Auditório

Acervo Silvio Oksman

Img 106 - Ata da reunião sobre o acesso do Parque Ibirapuera

Acervo Silvio Oksman

Img 107 - Imagem do projeto de Paulo Mendes da Rocha e MMBB Arquitetos para o novo acesso do Parque.

Acervo MMBB Arquitetos

Img 108 - Vista aérea do Parque do lbirapuera antes da construção do auditório

http://imgs.fbsp.org.br/files/PARQUE_IBIRA_00003-1.jpg

\section{Consideraçoes}

Img 109 - Tel Aviv Branca - Israel

https://www.artsy.net/article/artsy-editorial-tel-aviv-s-city-of-white-and-the-birth-of-bauhaus-in-palestine

Img 110 - Farnsworth House, Mies van der Rohe - Plano, Estados Unidos

Acervo Silvio Oksma

111 - Crown Hall, Mies van der Rohe - Chicago, Estados Unidos Acervo Silvio Oksman

Img 112 - Edificio da Bauhaus após inauguração, 1925

https://thecharnelhouse.org/2014/04/01/object-lessons-from-the-bauhaus/

Img 113 - Edificio da Bauhaus destruído após a II Guerra Mundia Miron, D. n.d. Bauhaus Dessau.

http://farm5.staticflickr.com/4144/4844930462_19bb7b442a b.jpg

Img 114 - Edificio da Bauhaus após a intervenção de 1976

http://mwwsmithsonianmag.com/smart-news/harvard-just-launched-fascinating-resource-all-about-bauhaus-180960150/ 
ANDRADE, Antonio Luiz Dias de. Um estado completo que pode jamais ter existido. São Paulo: Faculdade de Arquitetura e Urbanismo da Universidade de São Paulo, Tese de Doutoramento, 1993.

ANDRADE, Manuella Marianna. O parque do Ibirapuera: 1890 a 1954. Arquitextos, São Paulo ano 05, n. 051.01 Vitruvius, set. 2004 < http://www.vitruvius.com. br/revistas/read/ arquitextos/05.051/553>

ARGAN, Giulio Carlo. Walter Gropius e a Bauhaus. Lisboa: Editorial Presença, Coleção Dimensões, $2^{a}$ edição, 1990.

ASSMANN, Aleida. Espaços da recordação: formas e transformaçōes da memória cultural. Trad. Paulo Soethe. Campinas: Editora da UNICAMP, 2011.

BACELAR, Gabriela Goelzer. Reconstrução do Castelo de Berlim - Construção do Himboldt-Forum. São Paulo. Faculdade de Arquitetura e Urbanismo da Universidade de São Paulo, Trabalho Final de Graduação, jun. 2016.

BANHAM, Reyner. Teoria e projeto na primeira era da máquina. São Paulo: Editora Perspectiva, Coleção Debates nº 113, 3a edição, 2003.

BAUMANN, Kirsten. Bauhaus Dessau. Architecture Design Concept. Jovis Verlag GmbH, Berlim, 2007

BENEVOLO, Leonardo. História da Arquitetura Moderna. Trad. Ana M Goldberger. São Paulo: Perspectiva, 2006

BENJAMIN, Walter. A obra de arte na era da sua reprodutibilidade técnica In: Magia e técnica arte e política: ensaios sobre literatura e história da cultura. São Paulo: Magia e tecnica are

BOITO, Camillo. Os Restauradores. Trad. Beatriz Mugayar Kuhl e Paulo Mugayar Kuhl. São Paulo: Atelier Editorial, 2003 
BOURDIEU, Pierre/DELSAUT, Yvette. O costureiro e sua grife: contribuição para uma Teixeira. Educação em Revista, Belo Horizonte, no 34, dez. 2001.

BRANDI, Cesare. Teoria da restauração. Trad. Beatriz Mugayar Kuhl. Cotia: Ateliê, 2004

Processo all'architettura moderna. In l'Architettura Cronache e Storia nº 11,1956.

BRUAND, Yves. Arquitetura Contemporânea no Brasil. São Paulo: Perspectiva, 1997.

CAMARGO, Mônica Junqueira de. Sobre o projeto de Oscar Niemeyer para o entorno do Teatro no Parque Ibirapuera. Minha Cidade, São Paulo, 05.056, Vitruvius, mar. 2005. Disponivel Pm: < http://umw vituvius com br//revistas/read/minhacidade/05.056/1984>. Acesso em: 21 dez. 2016 .

CARBONARA, Giovanni. Avvicinamento al restauro. Apud KÜHL, Beatriz Mugayar Preservação do Patrimônio Arquitetônico da Industrialização. São Paulo: Atelie Editorial, 2008, pg 285-286.

Verbete: "Le tendenze attuali del restauro in architettura". In: Nuove Conoscenze . del'Arte Novara: Istituto Geográfico de Agostini, 2000, pp. 533-541.

CARRILHO, Marcos José. Restauração de obras modernas e a Casa da Rua Santa Cruz de Gregori Warchavchik. Arquitextos, São Paulo, 01.006, Vitruvius, nov. 2000. Disponível de Gregorl Warchavint Arght 21 dez 2016

CARTER, Peter. Mies van der Rohe at Work. Londres: Phaidon, 1999.

CARVALHO, Cláudia Suely R. de. Preservação da Arquitetura Moderna. São Paulo, Faculdade de Arquitetura e Urbanismo da Universidade de São Paulo, Tese de Faculdade de Arquiteh

Conservação preventiva de edifícios e sítios históricos: pesquisa e prática Revista CPC. São Paulo, no 18, p. 141-153, dez. 2014/abr. 2015.

CERVELLATI, Pier Luigi. Bolonia: política y metodología de la restauracion de centros histórico. Barcelona: Gustavo Gili, 1976.
CHOAY, Françoise. A Alegoria do Patrimônio. Trad. Luciano Vieira Machado. São Paulo: Estação Liberdade, UNESP, 2001

A regra e o modelo. São Paulo: Perspectiva, 1985

Patrimonio em questão - antologia para um combate. Trad. João G. A. Domingos. Belo Horizonte: Fino Traço, 2011.

CHUVA, Márcia Regina Romeiro. Fundando a nação: a representação de um Brasil barroco, moderno e civilizado. TOPOI, vol. 4, n. 7, p. 313-333, jul.-dez. 2003.

Os arquitetos da memória. Sociogênese das práticas de preservação do patrimônio cultural no Brasil (anos 1930 - 1940). Risco Original, Rio de Janeiro RJ Editora UFRJ, 2009.

CORONA, Eduardo \& LEMOS, Carlos A. C. Dicionário da arquitetura Brasileira. São Paulo: Edart, 1972.

COSTA, Lúcio Lúcio Costa: Registro de uma vivência. São Paulo: Empresa das Artes, 1995

COSTA, Sabrina Studart Fontenele. Edifícios modernos e o traçado urbano no centro de São Paulo. Annablume, São Paulo, 2015.

CRUZ, Leandro de Sousa. Arquitetura brutalista e habitação social: reflexões a partir do Robin Hood Gardens (inglatera). Texo apresentado ao $10^{\circ}$ DOCOMOMO partir

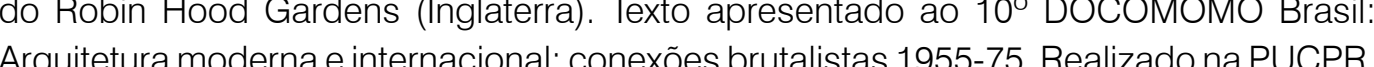
Curitiba: DOCOMOMO BR, 15-18 out 2013.

CUNHA, Claudia dos Reis e. A atualidade do pensamento de Cesare Brandi. Resenhas

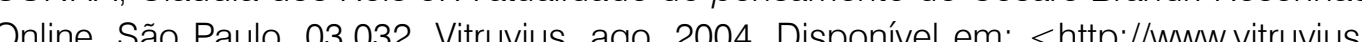
. Vitruvius, ago. 2004. Disponivel em: <http://www.vitruvius

CURY, Isabelle (org). Cartas Patrimoniais. Rio de Janeiro: IPHAN, 2000

DOLFF-BONEKÄMPER, Gabi. Sites of hurtful memory. Los Angeles: The Getty Conservation Institute Newsletter, vol 17 no 2, 2002. 
DURAND, José Carlos. Le Corbusier no Brasil. Negociação Política e Renovação Arquitetônica. Revista Brasileira de Ciências Sociais no 16, 1991. Disponivel em <http $/ /$ www.anpocs.org.br/portal/publicacoes/rbcs 00 16/rbcs16 01.htm>. Acesso em: 21 dez. 2016.

ETIENNE-Steiner, Claire, Saunier, Frédéric, Gauthiez, Bernard Préf, Haute-Normandie. Cahiers du patrimoine. Service régional de l'inventaire général. Ed. du patrimoine: Paris, 2005.

FABIAN, Dorottya. The meaning of authenticity and the early music movement: A Historical Review. In International Review of the Aesthetics and Sociology of Music Vol. 32, № 2 , p.153-167, dez. 2001

FERRAZ, Geraldo. Warchavchik e a Introdução da Nova Arquitetura no Brasil: 1925/1940, São Paulo: MASP, 1965, p51.

FERRAZ, Marcelo Carvalho (coord). Lina Bo Bardi. São Paulo: Instituto Lina Bo e P. M. Bardi, 1996.

FONSECA, Maria Cecília Londres. O Patrimônio em Processo - Trajetória Política Federal de Preservação no Brasil. Rio de Janeiro: UFRJ/Minc/PHAN, 1997.

FRAMPTON, Kenneth. Historia critica de la arquitectura moderna. México: Ediciones Gustavo Gili, 1983

FREIRE, Adriana. A última de Le Corbusier. In Arquitetura e Urbanismo, 169. São Paulo: Pini, abril de 2008.

GUERRA, Abilio. Monografia sobre Salvador Candia e a necessidade de um diálogo acadêmico. Resenhas Online, São Paulo, 07.078, Vitruvius, jun. 2008. Disponível em: acadénico. Resenhas Online, Sáo Paulo, 07.078, Vitruvius, jun. 2008. Disponivel em $<$ http:///ww.vitruvius.com.br/revistas/read/resenhasonline/07.078/3071 >. Acesso em:
$21 \mathrm{dez} .2016$.

GIEDION, S. Space, Time and Architecture, Cambridge, Harvard University Press, 1941 GUILLOT, Xavier (org). Firminy. Le Corbusier en heritage.Saint-Étienne: Publications de l'université de Saint-Étienne, 2008.

HABERMAS, J. Arquitetura Moderna e Pós Moderna. In: Dossier Habermas, Revista Novos Estudos CEBRAP, setembro, 1987.
HAYNES, Bruce. The end of early music: a period performer's history of music for the twenty-first century. Oxford: Oxford University Press, 2007.

JENCKS, Charles. The language of post-modern architecture. Rizzoli, NY: Academy Editions London 1977

KENYON, Nicholas (ed.). Authenticity and early music: a symposium. Oxford: Oxford University Press, 1980

KÜHL, Beatriz Mugayar. Preservação do Patrimônio Arquitetônico da Industrialização. São Paulo: Atelie Editorial, 2008.

"Conservação e restauração". Anais do Museu Paulista. São Paulo N N Sér v. 18 p. 287-320. jul. - dez. 2010.

. Restauração hoje: método, projeto e criatividade. São Paulo: Desígnio, no $6, \mathrm{p}$. 19-35, set. 2006.

__. (org) Gustavo Giovannoni, textos escolhidos. Ateliê Editorial, São Paulo, 2013.

KÜHL, Beatriz M./SALVO, Simona. Ciclo de palestras sobre preservação: Preservação 作 graduação em arquitetura e urbanismo da FAUUSP, no x. p. 198-210, 2006

LE CORBUSIER. A Carta de Atenas. [versão Le Corbusier: trad. de Rebeca Scherer]. São Paulo: HUCITEC,1989

. La charte d'Athènes. Paris: Plom, 1943.

. Por uma arquitetura. São Paulo: Perspectiva, 1981

Oeuvre complète en 8 volumes. Berilm: Birkhäuser, 1995

LE DUC, Eugene E. Viollet. Restauração. Trad. Beatriz Kuhl. São Paulo: Atelier Editorial, 2000

Entretiens sur l'architecture. Paris, Morel et Co., 1863-1872. 2v; reed. Bruxelas

LEFÈVRE, J. E. A. Marquise do Ibirapuera. Onde está o equívoco? São Paulo: Desígnio, no 4, p. 165-171, 2005 . 
LEITE, Rogério Proença. Contra-usos da cidade - lugares e espaço público na experiência urbana contemporânea. Campinas: Editora da Unicamp, 2004.

LEVI, Rino. Arquitetura e Cidade/Rino Levi [Renato Anelli (pesquisa e texto); Abílio Guerra (coordenacãa editorial); Nelson Kon (ensaios fotográficos)] São Paulo: Romano Guerra Editora, 2001

MARINS, Paulo César Garcez. Trajetórias de preservação do patrimônio cultural paulista In: SETÚBAL Maria Alice (coord.) Terra Paulista: trajetórias contemporâneas. São Paulo: CENPEC/Imprensa Oficial, 2008, p. 137-167.

MARKGRAF, Monika. Conservation and Preservation of the Bauhaus Building in Dessau. Heritage Risk Special, ICOMOS World Report 2006-2007 on Monuments and Sites in Danger, 2016.

MARTíNEZ Ascensión Hernández. La clonación arquitectónica. Madrid, Ediciones Siruela, 2007

MACEDO, Danilo M. Da matéria à invenção - as obras de Oscar Niemeyer em Minas Gerias 1938-1955. Brasília: Câmara dos Deputados, 2008.

MINC/IPHAN. Cadernos de Documentos $n^{\circ} 3$. Cartas Patrimoniais. Brasília: MinC/lphan, 1995

MINDLIN, Henrique Ephim. Brazilian architecture. Imprenta London: Royal College, 1961.

MONTANER, Josep Maria. El pavelló de Mies a Barcelona: una reconstrucció polèmica. In Temes de Disseny $n^{\circ} 2$.

MUNTADAS, J. On Translation: Paper/BP MVDR. Published by ACTAR ,Fundació Mies van der Rohe, España, 2009.

NEVES, Deborah Regina Leal. A persistência do passado: patrimônio e memoriais da ditadura em São Paulo e Buenos Aires. São Paulo, Faculdade de Filosofia, Letras e Citâncias Humanas da Universidade de São Paulo, Dissertação de Mestrado, 2014.

NOBRE, Eduardo A. C. Intervenções urbanas em Salvador: Turismo e "gentrificação" no processo de renovação urbana do Pelourinho. X Encontro Nacional da Anpur, 2003
ORTEGA Y GASSET, José. Miseria y esplendor de la traduccion. Scientia Traductionis, $n^{\circ}$ 3, 2013. Disponivel em: <http://dx.doi.org/10.5007/1980-4237. 2013n13p5>

PESSOA, José (Org.) Lúcio Costa: Documentos de trabalho. Rio de Janeiro: IPHAN, 2004

PEVSNER, N. Pioneiros do Desenho Moderno, São Paulo, Martins Fontes, 1980.

PINTO, L. Pierre Bourdieu e a teoria do mundo social. Trad. Luiz Alberto Monjardim. Rio de Janeiro: Editora FGV, 2000

PRUDON, Theodore H.M. Preservation of Modern Architecture. New Jersey: John Wiley \& Sons, Inc. 2008

QUETGLAS, Josep. El horror cristalizado. Barcelona: Actar, 2001.

RIEGL, Alö̈s Le cultemoderne des monuments. Son essence et sa genèse. Espacements, 1ère édition, Paris, Éditions du Seuil, 1984

RIVERA, Tania. Entre dor e deleite. Resenha de "Luto e melancolia", de Sigmund Freud Novos estudos - CEBRAP, no 94, São Paulo, nov. 2012. Disponível em: <http//dx doi org/10.1590/S0101-33002012000300016> Acesso em dez. 2016.

ROCHA, Paulo Mendes. Memorial do arquiteto Paulo Mendes da Rocha para o projeto de intervenço no Pavilhão Lucas Nogueira Garcez. 1998. Disponivel em < rmw mmbb. com.br> Acesso em 09/02/2011.

RODRIGUES, Alexandre. Iphan tomba 35 obras de Niemeyer. O Estado de S. Paulo, São Paulo, 07 dez. 2007.

RODRIGUES, Marly. Imagens do passado: A instituição do patrimônio em São Paulo 1969-1987. Campinas, Instituto de Filosofia e Ciências Humanas da Universidade Estadual de Campinas, Tese de Doutoramento, 1994.

ROGERS, Ernesto N. Esperienza dell'architettura. Trad. Horacio Crespo. Buenos Aires: Nueva Vision, 1965

ROGERS, E.N./SERT.J.L.JTYRWHITT, J. // Cuore della Città? Per una vitta piú umana delle comunità, Congressi Internazionali de Architettura Moderna, Milano Hoepli Editore, 1977. 


\section{ROSSI, Aldo. Arquitetura da Cidade. Martins Fontes, São Paulo, 2001}

RUBINO, Silvana. As fachadas da historia: os antecedentes, a criação e os trabalhos do Serviço do Patrimonio Historico e Artistico Nacional, 1937-1968. Campinas, Instituto de Filosofia e Ciências Humanas da Universidade Estadual de Campinas, Dissertação de Mestrado, 1992

RUSKIN, John. A lâmpada da memória. Tradução e apresentação Maria Lúcia Bressan Pinheiro. São Paulo: Atelier Editorial, 2008.

. The Seven Lamps of Architecture. Sunnyside, Kent, George Allen, 1889

SALVO, Simona. Restauro e "restauros" das obras arquitetônicas do século 20: intervençōes em arranha-céus em confronto. Trad. Beatriz Mugayar Kühl. Revista CPC São Paulo, nº 4, p.139-157, maio/out. 2007.

_. Arranha-céu Pirelli: crônica de uma restauração. Desígnio: 2006 (2007), n. 6, pp. $69-86$

A intervenção na arquitetura contemporânea como tema emergente do restauro, To dés-graducão em arquitetura e urbanismo da FAUUSP, no 23, p. 199-211, 2008

SANTOS, Mariza Veloso Motta. Nasce a academia SPHAN. In: Revista do patrimônio histórico e artístico Nacional, no 24. IPHAN, 1996.

SCHARLACH, Cecilia (org.) Oscar Niemeyer: a marquise e o projeto original do Parque |birapuera. Imprensa Oficial do estado de São Paulo, São Paulo, 2006

SCHORSKE, Carl E. Viena fin-de-sciècle: política e cultura. Cia das Letras/Ed. Unicamp,

SCRIVANO, Paolo/DE PIERI, Filippo. Representing the "historical centre" of bologna: preservation policies and reinvention of an urban identity. Urban History Review / Revue d'histoire urbaine, vol. 33, $\mathrm{n}^{\circ} 1$ 1, p. 34-45, 2004. Disponivel em: < http://id.eruditorg/ iderudit/1015673ar>

SOLÀ-MORALES, Ignasi; CIRICI, Cristian; RAMOS, Fernando. Mies van der Rohe: el Pabellon de Barcelona. Barcelona: Gustavo Gili, 1993.
UNDERWOOD, David. Oscar N

International Publication, 1994.

UNESCO. Orientação para a elaboração de Declarações de Valor Universal para bens do Patrimônio Mundial. Centro do Patrimônio Mundial da Unesco, 2008.

VALLE, Marco Antonio Alves do. Desenvolivmento da forma e procedimentos de projeto na arquitetura de Oscar Niemeyer (1935-1998). São Paulo, Faculdade de Arquitetura e Urbanismo da Universidade de São Paulo, Tese de Doutoramento, 2000.

VILANOVA ARTIGAS: Arquitetos Brasileiros. São Paulo: Instituto Lina Bo e P.M. Bardi: Fundação Vilan

WICK, R. Pedagogia da Bauhaus. São Paulo: Martins Fontes, 1989

WISNIK, Guilherme T. Joao Vilanova Artigas. 2G, Barcelona: Gustavo Gili, nº 54, 2010. Lúcio Costa. São Paulo: Cosac\&Naify Edições, 2001.

WOLFF, Silvia Ferreira Santos. Arquitetura moderna paulista - a preservação oficial. Texto apresentado ao São José dos Campos: DOCOMOMO_BR, 1998 .

XAVIER, Alberto LEMOS, Carlos CORONA Eduardo. Arquitetura Moderna Paulistana São Paulo: PINI, 1983.

ZEVI, B. "contro ogni teoria dell'ambientamento" in l'Architettura Cronache e Storia no 41,1965. Pg 212/213

Visione prospettica e spazio-temporalità nell'architettura moderna. In L'Architettura Cronache e Storia no 11,1956 


\section{ENDEREÇOS DE INTERNET CONSULTADOS}

http://mdc.arq.br/

http://portal.jphan.gov.br

http://www.cultura.sp.gov.br

http://www.docomomo.org.br/

http://www.museudacidade.sp.gov.br

http://www.vitruvius.com.br

http://www.icomos.org.br

http:// www.usp.br/cpc/

htto://arcoweb.com.br

PERIÓDICOS CONSULTADOS

L'Architettura Cronache e Storia.

L'architecture d'aujourd'hui no 7,1946.

DOMUS, no 649 , p. 2-13, 1984

Revista Acrópole

Pós: Revista do programa de pós-graduação em arquitetura e urbanismo da FAUUSP

LEGISLAÇÃO, PROCESSOS, RELATÓRIOS E PUBLICAÇÕES DA ADMINISTRAÇÃO PUBLICA.

BRASIL. IPHAN. Processo: 1.550/2007

SÃO PAULO (Estado). CONDEPHAAT. Processo: 63983/2011.

SÃO PAULO (Estado). CONDEPHAAT. Processo: 25767/1991.

SÃO PAULO (Estado). CONDEPHAAT. Processo: 31693/1994.

SÃO PAULO (Cidade). SMC/CONPRESP. Processo: 2003-0.035768-7

SÃO PAULO (Cidade). SMC/CONPRESP. Processo: 2004-0.154.355-9

UPPH/Centro de Documentação CONDEPHAAT Dossiê Artigas Secretaria da Cultuta 